\title{
장애인 접근성 강화를 위한 박물관-미술관 가이드라인 수립 방향 연구
}

김현경 



\section{장애인 접근성 강화를 위한 박물관-미술관 가이드라인 수립 방향 연구}

A Study on Establishing the Guideline of Museums and Art Galleries for Accessibility of Disabled Persons

김현경 

연구책임

김현경 한국문화관광연구원 연구원 

장애인 접근성 강화를 위한 박물관.미술관 가이드라인 수립 방향 연구

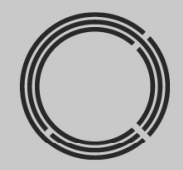

연구개요 



\section{1. 연구 배경 및 목적}

\section{가. 연구배경}

- 본 연구는 2019년 발표된 「박물관 및 미술관 진흥 중장기 계획(2019 2023)」 에서 장애인에 대한 접근성 강화 정책 사업을 명시한 바 이에 대한 후속조치로 서 진행되었음. 박물관.미술관은 국가의 중요한 공공문화기반시설로서 국민의 대표적인 문화향유 공간임

- 증가하고 있는 문화적 수요에 발맞춰 박물관-미술관은 다양한 문화적 서비스 를 제공하고 이를 통해서 사회적 책무를 다하고자 노력하고 있음. 반면 장애인 접근성 차원에서 물리적 접근성에 대한 장애인 편의제공 외에, 문화시설에서 의 접근성에 대한 다양한 논의가 이뤄지지 못한 상황임

\section{나. 연구목적}

- 이에 본 연구는 그간 정책 영역의 사각지대에 놓여있던 장애인 문화 접근성의 문제를 박물관·미술관 분야를 중심으로 살펴보고 이를 개선하고 더 나아가 강 화시킬 수 있도록 하는 가이드라인에 대한 방향성을 탐색하고자 함

[그림 1] 연구의 배경 및 목적

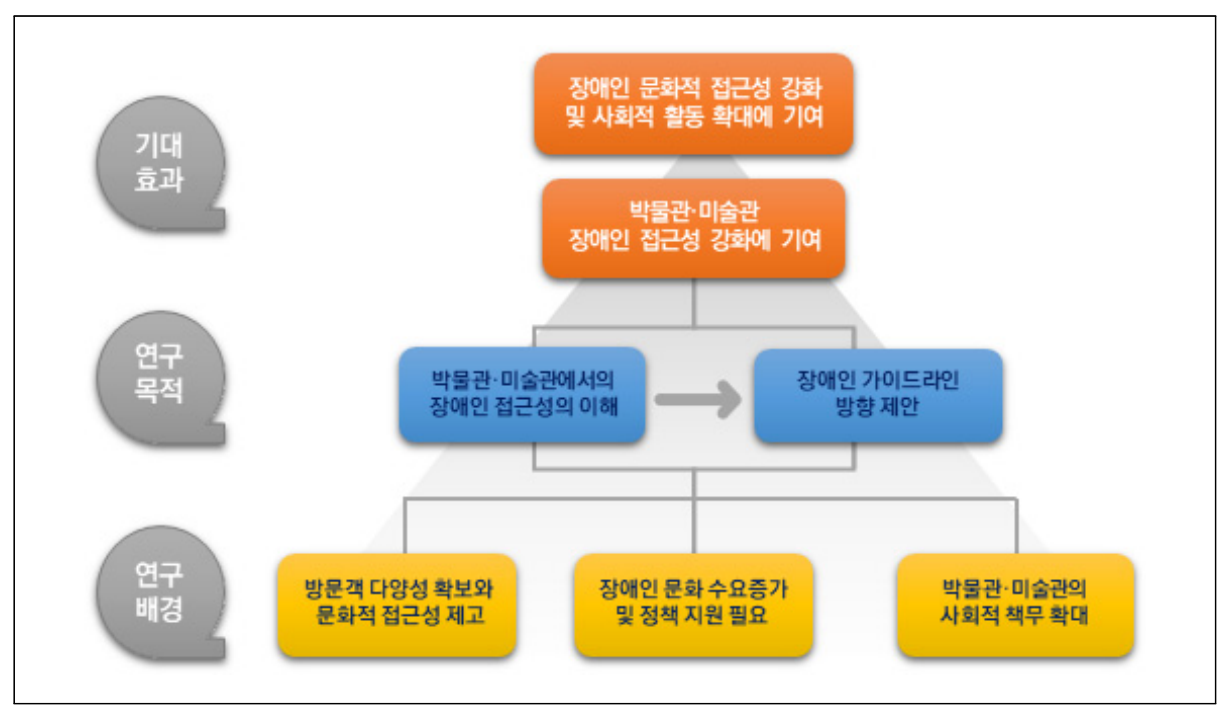




\section{2. 연구 범위 및 방법}

\section{가. 연구의 범위}

- 공간적 범위

- 연구의 공간적 범위는 국내 박물관·미술관이며, 주요 정책 대상으로서 국공립 운기관을 우선으로 두되, 정책 시행에 영향을 고려하여 사립관을 함께 고려함

- 시간적 범위

- 장애인 문화접근성에 대한 정책 환경으로 1989년 「장애인복지법」 제정 이후를 다루되, 1997 년 〈장애인·노인·임산부등의 편의증진보장에 관한 법률〉(이하 '장 애인등편의법'이라함) 2007 2008년(장애인 문화예술정책 추진, 「장애인차별 금지법」시행, 3차 장애인종합계획 수립) 이후를 중점적으로 다룸

- 내용적 범위

- 내용적 범위는 박물관.미술관 주요 기능을 중심으로 장애인 접근성이 적용될 수 있는 사항을 종합적으로 검토하되, 시설 설치 기준이 아닌 '장애인이 불편 없이 전시에 접근할 수 있는 환경 조성'에 대한 내용을 중점적으로 다룸

\section{나. 연구의 방법}

- 본 연구의 방법론으로는 문헌분석 및 시례분석, 기관 설문조사, 이용자 요구 분석을 위한 장애인, 복지관 관계자 전문가 및 실무자 FGI를 진행함

〈표 1〉조사 내용

\begin{tabular}{c|c|c|c|c}
\hline 구분 & 기관 현황조사 & \multicolumn{3}{|c}{ 서비스 요구조사 } \\
\hline \multirow{2}{*}{$\begin{array}{c}\text { 대상 } \\
\text { 2019년 기준 연 } \\
\text { 관람객 5만 이상의 } \\
\text { 국공립 박물관·미술관 }\end{array}$} & $\begin{array}{c}\text { 장애인(단독보행 가능, } \\
\text { 대학교 이상 학력, } \\
\text { 연 4회 이상 박물관. } \\
\text { 미술관 방문) }\end{array}$ & $\begin{array}{c}\text { 장애인 복지관 } \\
\text { 담당자/종합, } \\
\text { 뇌병변, 시각, 청각, } \\
\text { 발달장애 복지관 }\end{array}$ & $\begin{array}{c}\text { 관련 전문가 및 } \\
\text { 박물관/미술관 실무, } \\
\text { 비관 실무, 박물관 및 } \\
\text { 장애인 전문가 }\end{array}$ \\
\hline $\begin{array}{c}\text { 표본 수 } \\
\text { 모집단(222개) 중 } \\
\text { 115개 유효표본 수집 }\end{array}$ & 2인 & 10인 & 8인 \\
\hline $\begin{array}{c}\text { 기간/ } \\
\text { 횟수 }\end{array}$ & $\begin{array}{c}\text { 2020년 6월 9일 } \\
\text { 7월 15일 }\end{array}$ & 총 2회 & 총 4회 & 총 4회 \\
\hline 방법 & 온라인 웹 설문 & 1:1 면담 & $\mathrm{FGl}$ & $\mathrm{FGI/} \mathrm{1:1인터뷰}$ \\
\hline
\end{tabular}




\section{3. 박물관·미술관에서의 장애인 접근성 개념 및 범위}

\section{가. 박물관-미술관에서의 장애인 접근성의 개념}

1) 장애인의 정의 및 현황

- 우리나라「장애인복지법」에서는 장애인을 "신체적, 정신적 장애로 오랫동안 일상생활이나 사회생활에서 상당한 제약을 받는 자"로 2017년 기준 등록 장 애인은 총 261 만 8 천명이고, 전체 인구 수의 $5.1 \%$ 임

- “특수교육 대상자"란 교육장 또는 교육감이 다음의 어느 하나에 해당하는 사 람 중 특수교육을 필요로 하는 사람으로 진단.평가하여 선정된 사람을 말함 (「장애인 등에 대한 특수교육법」 제2조제3호 및 제15조). 2019년도 특수교육 대상자 규모는 전체 학생의 $1.4 \%$ 이다. 이중, 지적장애가 전체 특수교육대상자 의 $53.4 \%$ 를 차지하고 있다. 규모 순으로는 지적장애, 자폐성장애, 지체장애, 발달지체 순임

2) 박물관·미술관에서의 ‘장애인 접근성’의 의미

- 박물관·미술관 접근성은 '물리적 접근성'외에도 그곳에서 이뤄지는 모든 행위 에 대한 접근 가능성이라는 차원에서 박물관·미술관에 '어떻게' 다가올 수 있 게 하느냐는 문제를 포괄하고 있음

- 박물관의 서비스가 사회의 다양한 계층 모두에게 적용될 수 있도록 해야 한다 는 의미의 사회 포용적 역할이 확대되고 있는 상황임. 사회에서 누구도 '배제’ 되지 않도록 문화기관이 적극적인 임무를 수행해야한다고 봄. 이러한 관점에 서 장애인도 비장애인과 마찬가지로 문화시설의 다양한 서비스를 적극적으로 누릴 수 있도록 해야 함

3) 박물관·미술관에서의 ‘장애인 접근성’의 유형

- 특정 대상으로서 장애인의 접근성은 장애인의 특성을 고려하는 것이 우선이 되어야 함. 다른 한편으로는 장애인을 '특수한' 대상으로 분리되지 않도록 고 
려해야 하는 요소임. 이에 장애인 접근성의 강화는 박물관.미술관의 일반적인 접근성을 포괄하되, 장애인에게 필요한 요소를 중요도에 따라서 우선순위를 다르게 설정하는 방식으로 다뤄져야 함

- 이에 본 연구에서는 박물관·미술관의 접근성의 유형(Museums \& Galleries Commission, 1998)에 새롭게 변화된 환경에서 중시되는 요소(온라인 환경, 의사결정 및 문화적 접근)를 반영하고 박물관의 주요 4가지 요소인 공간(온라 인 공간 포함), 인력, 컬렉션, 관람객을 기준(다니엘 지로디, 1996) 으로 하여 장애인 접근성의 유형을 〈표 2〉과 같이 구분하고자 함

〈표 2〉본 연구에서 다루고자 하는 박물관·미술관 장애인 접근성 유형

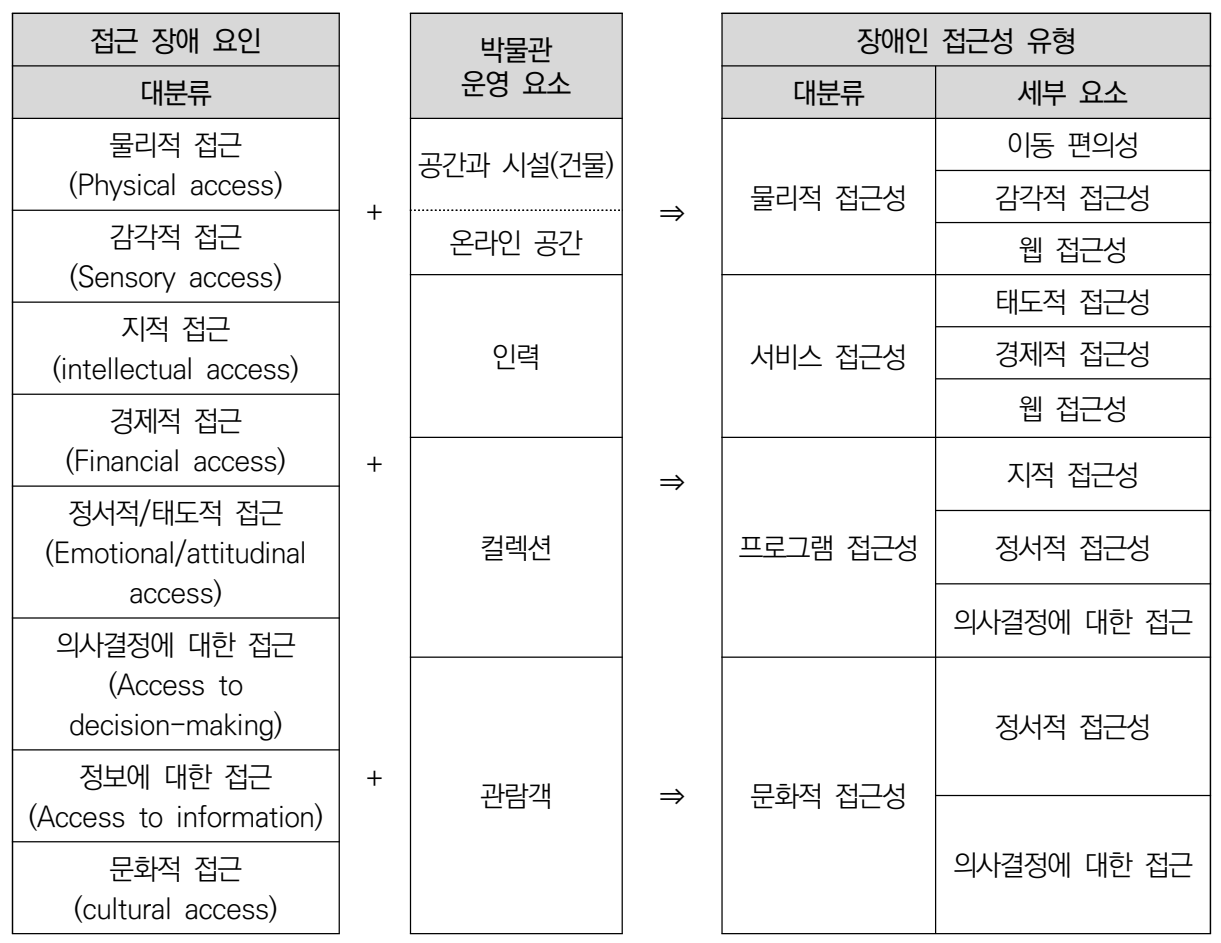

\section{나. 국내 장애인 박물관-미술관 접근성 관련 법제도}

1) 장애인의 박물관·미술관 접근성 관련 법률

- 「장애인복지법」을 중심으로 장애인관련 법률에서는 장애인의 문화예술 활동 
및 향유에 대하여 차별금지 및 편의제공을 명시하고 있음

- 그 외에 문화분야 법 제도 내에서도 문화권을 명시한 문화기본법 외에도, 문화 산업진흥법, 문화예술진흥법, 문화예술교육지원법, 문화다양성의 보호와 증진 에 관한 법률에 장애인이 문화예술활동을 차별 없이 할 수 있도록 편의를 제공 해야 한다고 명시함

2) 장애인의 박물관·미술관 접근성 관련 제도 및 정책

- 「장애인·노인·임산부 등의 편의증진 보장에 관한 법률」에 기초하여〈장애물 없는 생활환경 인증제도>가 대표적이며, 웹접근성 인증제도 등이 있음. 그 외 박물관·미술관 진흥법에 기초한 개별 박물관·미술관 내규 또는 규칙에 장애인 무료관람에 대한 내용이 명시되어 있음

- 그 외에 법률에 기초한 〈장애인 정책 종합계획〉, 〈편의증진 국가종합 5개년 계획〉, 〈박물관·미술관 진흥 중장기 계획〉, 〈관광진흥 5개년 계획〉, 〈관광개 발 기본계획> 등에서 장애인 접근성 대하연 정책을 명시하고 있음. 장애인 접 근성 유형별로 법제도 및 정책 현황은〈표 3〉과 같음

〈표 3〉 장애인 접근성 유형별 법제도 및 정책 현황

\begin{tabular}{|c|c|c|c|}
\hline 대분류 & 법률 & $\begin{array}{c}\text { 세부 접근성 } \\
\text { 요소 }\end{array}$ & 제도 및 정책 현황 \\
\hline \multirow[t]{3}{*}{$\begin{array}{l}\text { 물리적 } \\
\text { 접근성 }\end{array}$} & \multirow{3}{*}{$\begin{array}{l}\text { - 교통약자이동편 } \\
\text { 의 증진법 } \\
\text { - 장애인·노인. } \\
\text { 임산부등의 편의 } \\
\text { 증진보장에 관한 } \\
\text { 법률 } \\
\text { - 국가정보화 } \\
\text { 기본법」 제32조 } \\
\text { 의2제4항 }\end{array}$} & $\begin{array}{c}\text { 이동 } \\
\text { 편의성/물리적 } \\
\text { 환경 조성 }\end{array}$ & $\begin{array}{l}\text { - 편의증진 국가종합계획: 장애물 없는 생활환경 인증 } \\
\text { 확대 } \\
\text { - 제 } 5 \text { 차 관광진흥 } 5 \text { 개년 계획: 취약계층 관광 유니버설 } \\
\text { 디자인 도입 확대 } \\
\text { - 제3차 관광개발기본계획: 관광시설의 무장애화 추진 } \\
\text { - 박물관·미술관 진흥 중장기 계획: 박물관·미술관의 「장 } \\
\text { 애물 없는 생활환경 인증」취득 촉진 } \\
\text { - 장애물 없는 생활환경 인증제도 적용: 국공립, 대학, } \\
\text { 사립 박물관-미술관 }\end{array}$ \\
\hline & & 감각적 접근성 & $\begin{array}{l}\text { - 편의증진 국가종합 계획: 점자도서, 녹음서 등 대체자 } \\
\text { 료 제작·보급 } \\
\text { - 제6차 권역별 관광개발 계획(지역별): 장애인안내판 } \\
\text { 설치 가이드라인(대전권) } \\
\text { - 제5차 장애인정책 종합계획: 장애인을위한 정보통신 } \\
\text { 보조기기 개발·보급 }\end{array}$ \\
\hline & & 웹 접근성 & - 웹접근성 인증제도: 품질인증 마크 부여 \\
\hline
\end{tabular}




\begin{tabular}{|c|c|c|c|}
\hline 대분류 & 법률 & $\begin{array}{c}\text { 세부 접근성 } \\
\text { 요소 }\end{array}$ & 제도 및 정책 현황 \\
\hline \multirow{3}{*}{$\begin{array}{l}\text { 서비스 } \\
\text { 접근성 }\end{array}$} & \multirow{8}{*}{$\begin{array}{l}\text { - 장애인복지법 } \\
\text { - 장애인차별금지 } \\
\text { 및 권리구제 등에 } \\
\text { 관한 법률 } \\
\text { - 발달장애인 권리 } \\
\text { 보장 및 지원에 } \\
\text { 관한 법률 } \\
\text { - 저출산 고령사회 } \\
\text { 기본법 } \\
\text { - 문화기본법 } \\
\text { - 문화산업진흥법 } \\
\text { - 문화예술진흥법 } \\
\text { - 문화예술교육 } \\
\text { 지원법 } \\
\text { - 문화다양성의 } \\
\text { 보호와 증진에 } \\
\text { 관한 법률 } \\
\text { - 관광진흥법 }\end{array}$} & 태도적 접근성 & $\begin{array}{l}\text { - 제6차 권역별 관광개발 계획(서울시): 장애인/노약자 } \\
\text { 를 위한 전용 교통수단을 확대하고 이를 시행하는 기 } \\
\text { 업에 인센티브 제공 } \\
\text { - 박물관·미술관 진흥 중장기 계획: 박물관·미술관 가이 } \\
\text { 드라인 제시 }\end{array}$ \\
\hline & & 경제적 접근성 & $\begin{array}{l}\text { - 각 지자체별 조례로 지정한 박물관·미술관 운영 규칙: } \\
\text { 장애인 유료 면제 대상 } \\
\text { - 제5차 장애인정책 종합계획: 통합문화이용권 지원금액 } \\
\text { 현실화 }\end{array}$ \\
\hline & & 웹 접근성 & $\begin{array}{l}\text { - 박물관·미술관 진흥 중장기 계획: ‘(가칭)지역문화통합 } \\
\text { 정보시스템'어플리케이션 개발 } \\
\text { - 제5차 장애인정책 종합계획: 웹. 모바일 정보접근성 보장 }\end{array}$ \\
\hline \multirow[t]{3}{*}{$\begin{array}{l}\text { 프로그램 } \\
\text { 접근성 }\end{array}$} & & 지적 접근성 & $\begin{array}{l}\text { - 박물관·미술관 진흥 중장기 계획:(장애인) 대상 맞춤형 } \\
\text { 프로그램 심화 } \\
\text { - 박물관 및 미술관의 평가제도: 다양한 계층 교육 프로 } \\
\text { 그램 접근 } \\
\text { - 제5차장애인정책종합계획: 발달장애인(만9세 24세)을 } \\
\text { 위한 찾아가는 장애인 문화예술학교 지원 }\end{array}$ \\
\hline & & 정서적 접근성 & - \\
\hline & & $\begin{array}{l}\text { 의사결정에 } \\
\text { 대한 접근 }\end{array}$ & - \\
\hline \multirow{2}{*}{$\begin{array}{l}\text { 문화적 } \\
\text { 접근성 }\end{array}$} & & 정서적 접근성 & $\begin{array}{l}\text { - 제6차 권역별 관광개발 계획(서울시): 장애인 관광을 위 } \\
\text { 한 사회적 인식을 개선하여 장애인의 관광 기회 확대 }\end{array}$ \\
\hline & & $\begin{array}{l}\text { 의사결정에 } \\
\text { 대한 접근 }\end{array}$ & - \\
\hline
\end{tabular}

\section{4. 박물관·미술관 장애인 가이드라인 사례 분석}

\section{가. 박물관·미술관 장애인 가이드라인 선행연구}

- UN의 〈장애인 인권선언〉을 비롯한 장애인 관련 법제도를 근간으로하여 국외 의 경우 1990 년대 이후로 꾸준히 그 유형과 범주를 확장하면서 발간됨

- 박물관·미술관 공간의 특수성에 기인한 시설물 설치와 그에 따라 발생되는 서 비스 등에 대한 접근을 다루기 때문에 개별 박물관 차원보다는 박물관연합체 또는 국가단위 차원에서 다뤄짐

- 박물관-미술관 장애인 가이드라인의 경우, 규격화된 가이드라인이 정해져 있 
다고 보기 어렵고, 가이드라인의 '목적’에 따라 그 내용과 접근 방법이 상이하 게 나타남. 크게 장애인의 '전시'에 대한 디자인과 설치를 중심으로 다루는 것 과 좀 더 종합적인 차원의 서비스 영역을 포괄하는 유형으로 구분할 수 있음

- 국내에서는 공공부문에서 공식적으로 박물관·미술관 환경에서의 장애인 접근 성 가이드라인이 발간된 것은 없음. 다만, 문화예술시설의 장애인 접근과 관련 하여 일부 사례 또는 분야로 박물관·미술관을 다루고 있음

\section{나. 박물관·미술관 장애인 접근성 가이드라인 사례 분석}

- 국내에서는 공공부문에서 공식적으로 박물관·미술관 환경에서의 장애인 접근 성 가이드라인이 발간된 바가 없음으로 해외사례를 중심으로 사례를 분석함

〈표 4〉검토한 대표 가이드라인 내용 요약

\begin{tabular}{|c|c|c|}
\hline 검토한 가이드라인 & 세부 구성 & 시사점 및 후속 조치 \\
\hline $\begin{array}{c}\text { The Council for } \\
\text { Museums Archives } \\
\text { and Libraries(1997), } \\
\text { Disability Directory } \\
\text { for Museums and } \\
\text { Galleries }\end{array}$ & $\begin{array}{l}\text { - 총 3장으로 구성 } \\
\text { - 1장: 박물관 및 미술관에서의 장애인 접근성 } \\
\text { 과 관련한 원칙과 관련 통계, 용어, 법률에 대 } \\
\text { 한 설명 } \\
\text { - 2장: 주제별로 일반 지침과 세부 내용을 기술 } \\
\text { 함 } \\
\text { - 운영처계(institutional framework \& structures), } \\
\text { 운영정책(policies), 진단(consultation), 직 } \\
\text { 원교육(training), 접근성에 대한 진단 도구 } \\
\text { (access audits), 접견공간 및 방문자 관리 } \\
\text { (front of house \& visitor care), 마케팅 및 } \\
\text { 홍보(marketing \& publicity), 전시기법과 } \\
\text { 해석(display \& interpretation), 박물관과 } \\
\text { 포용 측면에서 교육의 역할(educational role } \\
\text { of the museum and inclusion), 자금 확보 } \\
\text { (funding) } \\
\text { - 3장에서는 참고자료와 관련한 사이트 및 연계 } \\
\text { 기관 등의 정보 }\end{array}$ & $\begin{array}{l}\text { - 문화시설에 대한 장애인 접근성 } \\
\text { 유형을 구분하고 이에 대한 기 } \\
\text { 본 원칙 및 수립 방향성을 제시 } \\
\text { 함 } \\
\text { - 후속 조치로 현장 실무자를 위 } \\
\text { 한 핸드북 형식의 장애인 서비 } \\
\text { 스 제공에 대한 안내 책자가이 } \\
\text { 드라인) 발간하여, 실무에 필요 } \\
\text { 한 정보제공 } \\
\text { - 디렉터리형 가이드라인 및 실무 } \\
\text { 자용 안내 가이드를 기초로 한, } \\
\text { 각 항에 내용과 연계된 장애인 } \\
\text { 친화 운영을 위한 기관 자가 진 } \\
\text { 단표를 개발하여 실무 현장에서 } \\
\text { 적용할 수 있도록 함 }\end{array}$ \\
\hline $\begin{array}{c}\text { Australian } \\
\text { Museum/National } \\
\text { Museum of } \\
\text { Australia(2005), } \\
\text { Many voices making } \\
\text { choices: Museum } \\
\text { audiences with } \\
\text { disabilities }\end{array}$ & $\begin{array}{l}\text { - 총 } 6 \text { 개 분야로 구성 } \\
\text { - 1. 서론(장애 개념과 현황) } 2 \text {.접근성을 개선하 } \\
\text { 기 위해서? 3. 박물관과 미술관의 방문 과정 } \\
\text { 4. 전시 접근성 개선 5. 직원이 알아야 할 것 } \\
\text { 들 } 6 . \text { 주요사항과 추천 사이트 }\end{array}$ & $\begin{array}{l}\text { - 접근성의 문제를 단순히 물리적 } \\
\text { 인 접근성뿐만 아니라, 정보, 경 } \\
\text { 제적, 심리적 접근성 등으로 세 } \\
\text { 분화하여 각각의 장벽에서 발생 } \\
\text { 하는 문제에 대한 개선 방향을 } \\
\text { 제시하는 근거를 마련 } \\
\text { - 박물관 장애인 포용 실행 계획 } \\
\text { 의 근거로 활용됨 }\end{array}$ \\
\hline
\end{tabular}




\begin{tabular}{|c|c|c|}
\hline 검토한 가이드라인 & 세부 구성 & 시사점 및 후속 조치 \\
\hline $\begin{array}{c}\text { EU(2017), Report on } \\
\text { the accessibility in } \\
\text { Central Europe }\end{array}$ & $\begin{array}{l}\text { - 총 } 4 \text { 개의 파트로 구성 } \\
\text { - 1장: EU 협력 박물관의 협의를 통해서 완성 } \\
\text { 된 접근성 지표를 통하여, 현재 상황, 접근성 } \\
\text { 개선을 위해 필요사항 체크 } \\
\text { - 2장: 유엔 협약에 따른 접근성의 다양한 측면 } \\
\text { 과 아울러 중소 박물관을 위한 서비스 체인을 } \\
\text { 포함매트릭스를 사용하여 접근성을 개선하기 } \\
\text { 위해 중소 박물관이 반드시 갖춰야 할 필수 조 } \\
\text { 건을 설명 } \\
\text { - 3장: Law Framework로 UN 장애인의 권리 } \\
\text { 에 관한 협약, 유럽 장애 전략 } 2010 ~ \\
\text { 및 관련 EU-Directives를 분석하여 CE 국가 } \\
\text { 의 비교 } \\
\text { - 4장: 타 박물관의 온라인상의 정보 및 지식 접 } \\
\text { 근성 우수 관리 기준 사례 }\end{array}$ & $\begin{array}{l}\text { - 접근성과 관련한 다양한 이슈를 } \\
\text { 매트릭스로 유형화하여 현 상황 } \\
\text { 을 진단하고 이러한 진단에 기 } \\
\text { 초한 접근성 개선의 가이드라인 } \\
\text { 을 제시 } \\
\text { - 초 국가적으로 다양한 국가의 } \\
\text { 기관의 선례 등을 공유하여, 좀 } \\
\text { 더 나은 방향으로 개선할 수 있 } \\
\text { 도록 돕는 '가이드라인'으로서 } \\
\text { 의 기능 }\end{array}$ \\
\hline $\begin{array}{c}\text { 프랑스 문화부(2017), } \\
\text { Guide Exposition et } \\
\text { parcours de visite } \\
\text { accessibles }\end{array}$ & $\begin{array}{l}\text { - 크게 2개의 파트로 구성되어있으며, 세부 항 } \\
\text { 목에서는 7개의 영역으로 구분하여 기술 } \\
\text { - 1장(서론)에서는 접근성의 범주와 개념, 유니 } \\
\text { 버설디자인의 원칙 } \\
\text { - 2장에서는 전시장 구성 시, 실무에서 적용되 } \\
\text { 는 요소별 가이드라인을 분야별로 구분하고 } \\
\text { 각각에 필요한 인체공학적 분석과 설계의 지 } \\
\text { 침을 설명: 전시 디자인(La scenographie } \\
\text { d'une exposition), 전시에 필요한 진열장 등 } \\
\text { (mobilier), 조명(eclairage), 그래픽과 표지 } \\
\text { 판(signaletique et graphisme), 음향(son), } \\
\text { 멀티미디어(multimedia), 전시보조기구(expots) }\end{array}$ & \begin{tabular}{|l} 
- 2007년부터 발간된 문화시설 \\
분야 가이드라인의 전시분야 가 \\
이드라인임: 일반개론(2007), \\
〈공연예술 분야(2009) 〈정신 \\
장애인 수용(가능) 문화장소〉 \\
(2010) \\
- 다양한 인체공학적 정보는 물론 \\
디지털 기술 적용을 통한 접근 \\
성 개선 지침을 구체적으로 \\
다룸 \\
- 실무 지침서로 활용할 수 있는 \\
다양한 상황을 이미지로 표현하 \\
여 정보 전달력을 높였음
\end{tabular} \\
\hline
\end{tabular}

자료: 분석 내용을 기초로 연구자 재정리

\section{5. 박물관·미술관에서의 장애인 접근성 현황 및 요구 분석}

- 현재 국가에서 박물관·미술관의 관람객 수는 매년 조사하고 있지만(문화체육 관광부, 2019), 관람 실태와 관련하여 발간되는 통계가 없고, 개별 기관에서 관람객 만족도 조사를 수행하는 것이 전부인 실정임

- 관람객으로서의 장애인에 대한 관람 실태를 포함한 접근성 관련 내용을 통계 적으로 파악하기 어려움

- 가이드라인의 경우 기본적인 현황과 그에 따른 문제점을 개선하는 방식으로 
기술되어야하는데, 데이터의 부재로 타당한 근거를 지닌 가이드라인 수립이 어려운 상황임

- 이에 본 연구에서는 공급 관점에서의 박물관·미술관 장애인 관련 사업 운영 현황을 살펴보는 동시에 서비스 수요자로서 장애인 및 장애인 복지관 담당자 들 서비스 요구에 대한 조사를 실시 분석하여 연구 데이터로 활용 함

\section{가. 국내 박물관-미술관 장애인 접근성 관련 운영 현황}

- 박물관·미술관의 장애인 관련 서비스 및 운영현황에 대한 설문 조사를 시행 함. 모집단은 전국의 연평균 관람객 5 만 명 이상의 공립박물관·미술관을 222 개소를 대상으로 약 한 달간 조사하였고, 전체 모집단의 $52 \%$ 로 유효표본 115 개를 확보하여 SPSS 22.0을 활용한 빈도 및 교차분석 함

- 설문은 크게 2 개의 파트로 구성됨. 장애인 접근성 유형을 기초로 하여 기관의 장애인 관람객 접근성 개선을 위한 활동에 대하여 운영정책, 조사 및 연구, 직 원교육, 직원 고용, 의견수렴 피드백의 5 가지 항목에 대한 총 13 개의 문항과 박물관·미술관에서 나타날 수 있는 접근의 장벽에 대한 박물관·미술관 운영현 황을 파악하고, 의견을 묻는 총 15 개의 문항을 제시함

\section{나. 박물관·미술관 장애인 접근성 관련 수요자 요구 분석}

- 수요자로서 장애인 및 장애인 복지관 복지사, 박물관·미술관 실무자, 장애인 편의시설 관련 전문가 총 20 명 대상으로 $1: 1$ 면담과 FGI로 장애인 서비스 요 구 조사함

- 2020년 7월 20일 9월 1일까지 총 9회 실시함. 1:1 인터뷰와 FGI는 동일하 게 장애인들의 문화 활동 중 박물관·미술관 관람의 현황(방문횟수, 방문 선호 등)과 방문 여정에서의 접근 장애 여부, 개선점에 대한 제안 등을 공통으로 사 전에 숙지하도록 하고 진행함

- 공급자로서 박물관·미술관 현황과 서비스 요구사항을 종합하면 다음의〈표 5〉와 같음 
〈표 5〉 장애인 접근성 유형별 도출된 현황 조사 및 요구 분석 결과 종합

\begin{tabular}{|c|c|c|c|}
\hline \multicolumn{2}{|c|}{ 접근성 유형 } & \multirow{2}{*}{ 조사된 박물관·미술관 현황 } & \multirow{2}{*}{ 서비스 요구 사항 } \\
\hline 대분류 & 세분류 & & \\
\hline \multirow{3}{*}{$\begin{array}{l}\text { 물리적 } \\
\text { 접근성 }\end{array}$} & 이동 편의성 & $\begin{array}{l}\text { - 제공되는 서비스 중 이동 수단 } \\
\text { 제공이 높음(77.4\%) }\end{array}$ & $\begin{array}{l}\text { - 유니버설디자인 고려한 시설 점검 필요 } \\
\text { - 대중교통 도착과 건물입구까지 이동편의 종합 } \\
\text { 적인 제고 필요 } \\
\text { - 전반적 안내판 설치에서 장애인 눈높이 고려 } \\
\text { - 휠체어 이용자의 눈높이 등 고려 필요 }\end{array}$ \\
\hline & 감각적 접근성 & $\begin{array}{l}\text { - 장애 유형별 보조장비의 설치 } \\
\text { 비율이 높지 않음(가장 높은 } \\
\text { 것이 점자책자 } 17.4 \% \text { 이나, 다 } \\
\text { 국어리플렛 } 34.8 \% \text { 보다 낮음) }\end{array}$ & $\begin{array}{l}\text { - 장애인 유형별 보조 안내자료 비치 } \\
\text { - 유형별 안내 보조원 또는 전시 설명자(도슨 } \\
\text { 트) 배치 희망 }\end{array}$ \\
\hline & 웹 접근성 & $\begin{array}{l}\text { - 장애인을 위한 별도 홈페이지 } \\
\text { 가 설치되지 않음(96.3\%) }\end{array}$ & $\begin{array}{l}\text { - 장애 유형별 홈페이지 제작 필요 } \\
\text { - 웬접근성 고려한 홈페이지 및 온라인 콘텐츠 } \\
\text { 설계 필요 }\end{array}$ \\
\hline \multirow{3}{*}{$\begin{array}{l}\text { 서비스 } \\
\text { 접근성 }\end{array}$} & 태도적 접근성 & $\begin{array}{l}\text { - 담당직원의 접근성 관련 숙지 } \\
\text { 여부(53\%) } \\
\text { - 전체 운영 사업비의 거의 없거 } \\
\text { 나 } 5 \% \text { 가 안됨(93.5\%) }\end{array}$ & $\begin{array}{l}\text { - 직원 장애인에 대한 응대 방식 교육필요 } \\
\text { - 장애인의 이동속도 및 다양한 상황에 대한 배 } \\
\text { 려 필요 } \\
\text { - 직원들의 필요서비스에 대한 숙지 필요 }\end{array}$ \\
\hline & 경제적 접근성 & $\begin{array}{l}\text { - 내부 규정 내 입장료 징수(무료 } \\
\text { 입장) 관련 항목이 있음(47\%) }\end{array}$ & $\begin{array}{l}\text { - 무료관람 입장이지만, 기획 전시나 비용이 높 } \\
\text { 은 유료 전시의 할인율이 높다고 보기 어려움 }\end{array}$ \\
\hline & 웹 접근성 & $\begin{array}{l}\text { - 홍보가 별도로 이뤄지지 않음 } \\
\text { (44.3\%) } \\
\text { - 웹접근성을 고려하지 않음 } \\
\text { (71.3\%) }\end{array}$ & $\begin{array}{l}\text { - 박물관여정에 대한 종합적 정보페이지 필요 } \\
\text { - 박물관 주변시설(음식점 등)에 대한 정보 제 } \\
\text { 공 필요 }\end{array}$ \\
\hline \multirow{3}{*}{$\begin{array}{l}\text { 프로그램 } \\
\text { 접근성 }\end{array}$} & 지적 접근성 & $\begin{array}{l}\text { - 장애인 프로그램 기획 직원이 전 } \\
\text { 문분야 습득하지 않음( } 95.7 \%) \\
\text { - 전연령 대상의 일반 프로그램 } \\
\text { 이 다수(47.3\%)이며 청소년이 } \\
\text { 나 어린이 중심 프로그램 운영 }\end{array}$ & $\begin{array}{l}\text { - 장애 유형 및 인지에 따른 단계별 교육 필요 } \\
\text { - 쉽고 단순한 내용으로의 정보 전달 필요 } \\
\text { - 생애 주기별 접근 필요 } \\
\text { - 통합교육 차원의 접근 } \\
\text { - 온라인 콘텐츠 등에 대한 소개 이상의 적극적 } \\
\text { 참여가능한 프로그램 필요 } \\
\text { - 매개자(복지사, 보조인 등) 교육을 통하여 문 } \\
\text { 화예술 체험 기회 확대 노력 필요 }\end{array}$ \\
\hline & 정서적 접근성 & $\begin{array}{l}\text { - 장애인 프로그램이 정기적으로 } \\
\text { 이뤄지 않음(87\%) }\end{array}$ & $\begin{array}{l}\text { - 체험교육을 통한 기간에 대한 친밀감 제고 } \\
\text { - 지역에서의 미술관 경험/미술 체험에 대한 기 } \\
\text { 회 확대 필요 }\end{array}$ \\
\hline & $\begin{array}{l}\text { 의사결정에 } \\
\text { 대한 접근 }\end{array}$ & $\begin{array}{l}\text { - 장애인 만족도조사가 별도로 } \\
\text { 이뤼지지 않음 }(65.2 \%) \\
\text { - 장애인 전문가 자문을 받지 않 } \\
\text { 음( } 96.5 \%) \\
\text { - 장애인 직원이나 자원봉사 결 } \\
\text { 도 모집 창구가 없음 }(79.1 \%)\end{array}$ & $\begin{array}{l}\text { - 서비스 설계에 장애인의견 수렴 } \\
\text { - 장애인 예술 활동의 결과 또는 장애예술인 작 } \\
\text { 품 전시의 기회 제공 필요 } \\
\text { - 장애인 인식개선 관련 테마 주제 기획필요 }\end{array}$ \\
\hline
\end{tabular}




\begin{tabular}{|c|c|c|c|}
\hline \multicolumn{2}{|c|}{ 접근성 유형 } & \multirow{2}{*}{ 조사된 박물관·미술관 현황 } & \multirow{2}{*}{ 서비스 요구 사항 } \\
\hline 대분류 & 세분류 & & \\
\hline \multirow[b]{2}{*}{$\begin{array}{l}\text { 문화적 } \\
\text { 접근성 }\end{array}$} & 정서적 접근성 & $\begin{array}{l}\text { - 아웃리치 프로그램이 운영되지 } \\
\text { 않음(75.4\%) }\end{array}$ & $\begin{array}{l}\text { - 장애인 문화여가 활동 공간으로 활용 } \\
\text { - 직원 및 운영 전반 장애 감수성 고려 } \\
\text { - 아웃리치 프로그램 및 학교연계 활성화 }\end{array}$ \\
\hline & $\begin{array}{l}\text { 의사결정에 } \\
\text { 대한 접근 }\end{array}$ & $\begin{array}{l}\text { - 장애인 프로그램을 관리하는 } \\
\text { 중간관리자 없음( } 96.5 \%) \\
\text { - 장애인 접근성 관련 계획 수립 } \\
\text { 이 없음(47.8\%) } \\
\text { - 장애인 친화적이지 않음 } \\
\text { (77.4\%) }\end{array}$ & $\begin{array}{l}\text { - 장애인 고용 활성화 } \\
\text { - 복지관-박물관 직원간 의견 교류를 통한 장 } \\
\text { 벽완화 노력 } \\
\text { - 부처간 노력을 통한 장애인 중심 서비스 개선 } \\
\text { 노력 필요 }\end{array}$ \\
\hline
\end{tabular}

\section{6. 장애인 접근성 강화를 위한 가이드라인 수립 방향}

- 도출된 이슈와 현황 조사의 결과를 2장에서 구분한 장애인 접근성의 유형에 따라 재분류하고 이를 종합하여 가이드라인의 기본 원칙과 수립 방향을 〈표 6)과 같이 제안함

- 기본 원칙과 가이드라인 수립 방향으로 구성함 기본 원칙에서는 장애인 접근 성 강화에 대한 종합적 방향성을 제시하고 세부 방향에서 영역별 가이드라인 세부적인 내용을 다룸

- 분야별로 원칙을 중심으로 제시하되 차후 구체적 가이드라인 도출을 위한 참 고자료로 국내외 관련 가이드라인 및 프로그램 운영 사례를 제시함

- 기본 원칙은 장애인 문화활동으로서 박물관·미술관에서의 활동이 갖는 의미 를 장애의 사회적 모델과 인클루시브/유니버설디자인, 그리고 박물관·미술관 의 사회적 책무의 차원에서 다음의 3 가지로 제시하고 접근성 유형에 따라 4 개 의 가이드라인 수립 방향을 제시함

- 가이드라인 방향의 세부적인 구성에 있어, 살펴본 해외 사례 중 박물관.미술 관에서의 장애인 접근과 관련한 기본 원칙을 담은 영국 The Council for Museums Archives and Libraries(1997), 호주 Australian Museum/ National Museum of Australia(2005)의 구성을 참조함 
〈표 6〉 장애인 접근성 강화를 위한 박물관-미술관 가이드라인의 구성

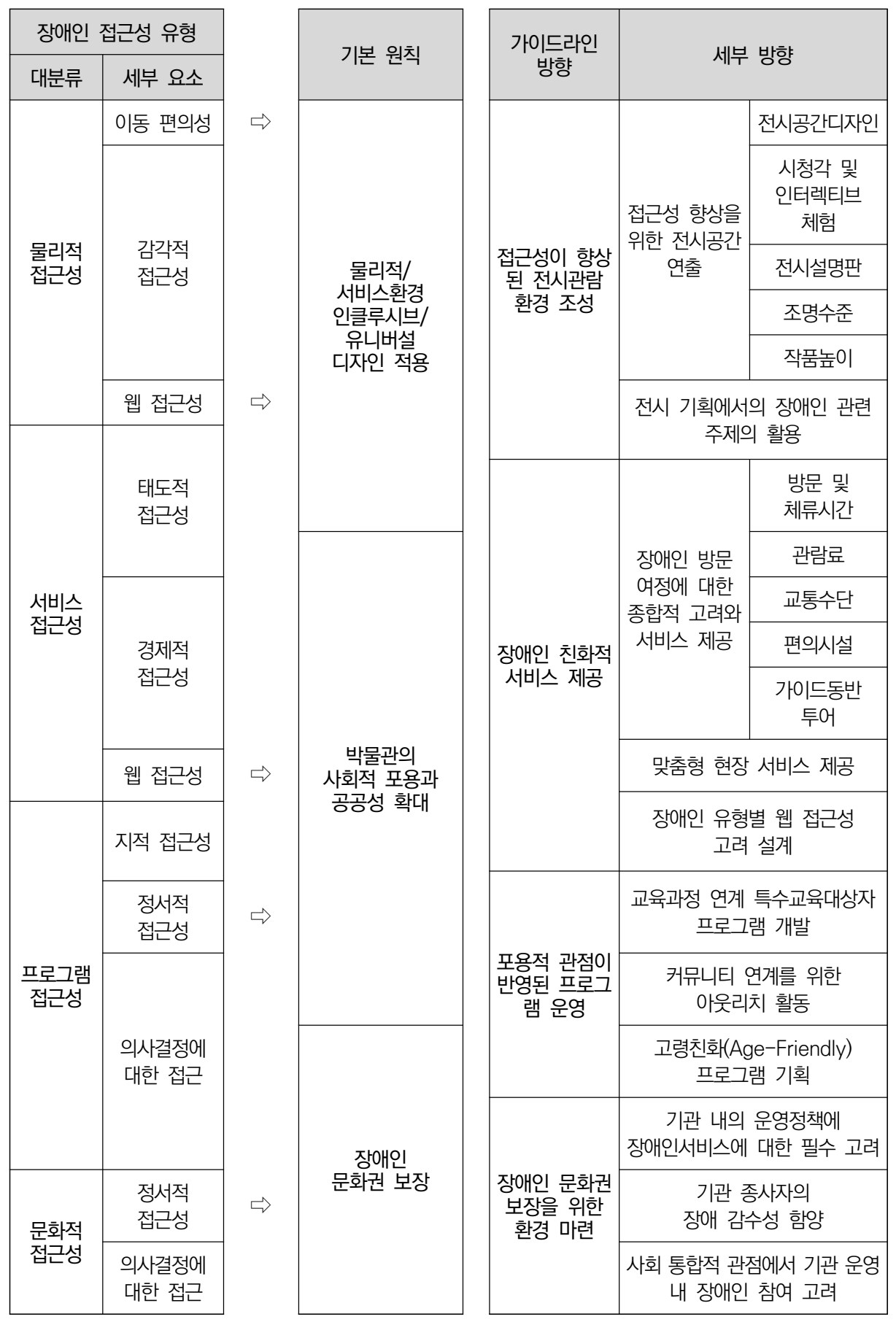




\section{7. 박물관·미술관 장애인 가이드라인 수립을 위한 제언}

- 본 연구는 문화시설 중 박물관·미술관 환경에 특화된 장애인 가이드라인에 관 한 선행연구를 분석하고, 현재 국공립 박물관·미술관의 장애인 관련 사업 운 영현황과 서비스 요구사항 등을 파악하여 가이드라인 수립을 위한 방향을 도 출하였음

- 제시된 가이드라인 수립 방향은 박물관-미술관 환경에서 장애인을 위한 서비 스, 프로그램, 환경을 만드는데 필요한 원칙임. 이러한 원칙을 기초로 하여, 본격적인 가이드라인 수립이 후속적으로 반드시 이뤄져야 함

- 특히 본 연구에서는 장애인 유형별 접근성 개선 방식, 서비스 제안의 경우 세 부적으로 다뤄지지 못한 한계를 갖음

- 이는 후속연구와 가이드라인 수립을 통하여 유형별 장애인들의 대표성을 고려 한 표본을 설정하고 세부 서비스를 UX 분석 및 설계를 통하여 본격적으로 다 뤄야 할 영역임

- 이와 함께 장애인의 문화시설에 대한 이용 현황과 실태를 정확히 파악할 수 있는 조사가 정기적으로 이뤄져야함

- 현재 장애인편의시설과 관련한 조사를 통해 편의시설 개선의 원칙이 발전하는 것과 마찬가지로 장애인의 문화시설 이용현황을 근거로 장애인 문화접근성 개 선을 위한 기반을 마련이 필요함 



\section{목차}

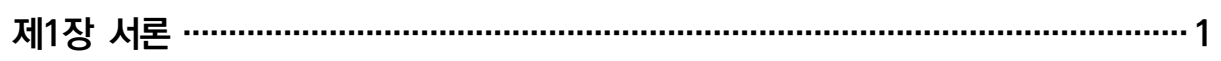

제1절 연구 배경 및 목적 3

1. 연구 배경 3

2. 연구 목적 5

제2절 연구 범위 및 방법 1

1. 연구 범위

2. 연구 방법 8

제2장 박물관-미술관에서의 장애인 접근성 개념 및 범위 ……………................. 11

제1절 박물관·미술관에서의 장애인 접근성의 개념 13

1. 장애인의 정의 및 현황 13

2. 박물관·미술관에서의 '장애인 접근성'의 의미 15

3. 박물관·미술관에서의 '장애인 접근성'의 유형 20

제2절 국내 장애인 박물관·미술관 접근성 관련 법제도 24

1. 장애인의 박물관·미술관 접근성 관련 법률 24

2. 장애인의 박물관·미술관 접근성 관련 제도 및 정책 26

제3장 박물관-미술관 장애인 가이드라인 사례 분석 ……………………………... 33

제1절 박물관·미술관 장애인 가이드라인 선행연구 35

1. 해외 박물관·미술관 장애인 가이드라인의 발전과 유형 35

2. 국내 박물관·미술관 장애인 가이드라인 선행연구 검토 39

제2절 박물관·미술관 장애인 접근성 가이드라인 사례 분석 43

1. The Council for Museums Archives and Libraries(1997),

Disability Directory for Museums and Galleries 44 
2. Australian Museum/National Museum of Australia(2005), Many Voices Making Choices: Museum Audiences with Disabilities 48

3. DCMS(2008), Secretary of State Report on Disability Equality Department for Culture Media and Sport 50

4. EU(2017), Report on the Accessibility in Central Europe

5. 프랑스 문화부(2017), Guide Exposition et Parcours de Visite Accessibles

\section{제4장 박물관·미술관에서의 장애인 접근성 현황 및 요구 분석 …………………...61}

제1절 조사 및 분석 개요 63

1. 박물관·미술관 장애인 접근성 관련 운영현황 조사 63

2. 이용자 서비스 수요조사 및 분석 65

제2절 국내 박물관·미술관 장애인 접근성 관련 운영현황 66

1. 기관 운영에서의 장애인 고려 여부 66

2. 기관 서비스와 프로그램 운영 현황 72

3. 장애인 관련 기관 운영 방향 77

제3절 박물관·미술관 장애인 접근성 관련 수요자 요구 분석 79

1. 박물관·미술관에서의 장애인의 물리적 접근방식과 제반 환경 79

2. 박물관·미술관에서의 장애인 서비스 접근성 84

3. 박물관·미술관의 장애인 대상 프로그램 운영 89

4. 문화접근성을 높이기 위한 노력 '모두를 위한 박물관·미술관' 95

제4절 소결 99

제5장 장애인 접근성 강화를 위한 가이드라인 수립 방향 …………………....... 105

제1절 가이드라인의 구성 및 기본 원칙 107

1. 장애의 사회적 모델과 장애인 문화예술 참여 109

2. 문화시설의 특수서비스와 장애인을 고려한 인클루시브 디자인 적용 110

3. 박물관·미술관의 사회적 포용과 공공성의 실현 112

제2절 '접근성이 향상된 전시' 관람환경 조성 114

1. 접근성 향상을 위한 전시공간 연출 115

2. 전시 기획에서의 장애인 관련 주제의 활용 119 
제3절 장애인 친화형 서비스 제공

1. 장애인 방문 여정에 대한 종합적 고려와 서비스 제공 121

2. 맞춤형 현장 서비스 제공 124

3. 장애인 유형별 웹 접근성 고려 설계 126

제4절 포용적 관점이 반영된 프로그램 운영 128

1. 교육과정 연계 특수교육대상자 프로그램 개발 128

2. 커뮤니티 연계를 위한 장애인 아웃리치(outreach)프로그램 $\quad 130$

3. 고령친화(Age-Friendly) 프로그램 기획 131

제5절 장애인 문화권 보장을 위한 환경 마련 132

1. 기관 내의 운영정책에 장애인서비스에 대한 필수 고려 132

2. 기관 종사자의 장애 감수성 함양 136

3. 사회 통합적 관점에서 기관 운영 내 장애인 참여 고려 138

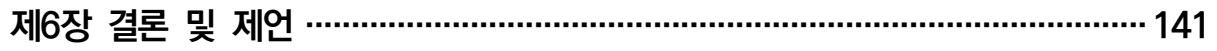

제1절 결론 143

$\begin{array}{ll}\text { 제2절 제언 } & 146\end{array}$

\section{참고문헌 / 149}

ABSTRACT / 153

부록 / 159 


\section{표 목차}

〈표 1-1〉조사 내용 8

〈표 2-1〉 특수교육대상자와 장애인복지법의 장애인 유형 14

〈표 2-2〉 접근성의 유형에 따른 박물관·미술관 방문객 개발 관점 적용 16

〈표 2-3〉 본 연구에서 다루고자 하는 박물관·미술관 장애인 접근성 유형 22

〈표 2-4〉 제5차 장애인정책 종합계획(2018 2022) 내 박물관·미술관 장애인 접근성 관련 항목 29

〈표 2-5〉 편의증진 국가종합 계획 세부 계획 중 박물관-미술관 접근성 관련 항목 30

〈표 2-6〉 박물관·미술관 진흥 중장기 계획 내 장애인 접근성 관련 항목 30

〈표 2-7〉 관광관련 국가종합 계획 세부 계획 중 박물관-미술관 접근성 관련 항목 31

〈표 2-8〉 장애인 접근성 유형별 법제도 및 정책 현황 32

〈표 3-1〉 본 연구에서 검토한 국외 장애인 관련 박물관-미술관 가이드라인 37

〈표 3-2〉 접근성 메트릭스: 방문 전 정보 및 소통 단계 55

〈표 3-3〉 검토한 대표 가이드라인 내용 요약 58

〈표 4-1〉 박물관·미술관 기관 대상 장애인 서비스 현황조사 개요 64

〈표 4-2〉응답 기관 특성 64

〈표 4-3〉이용자 서비스 수요조사 개요 65

〈표 4-4〉 장애인 접근성 유형별 도출된 현황 조사 및 요구 분석 결과 종합 102

〈표 5-1〉 장애인 접근성 강화를 위한 박물관·미술관 가이드라인의 구성 108

〈표 6-1〉 장애인 접근성 강화를 위한 가이드라인 기본원칙과 수립방향 145

〈표 6-2〉 국내 국립 도서관 장애인 관련 서비스관련 정책 연구 보고서 147 


\section{그림 목차}

[그림 1-1] 연구의 수행방법 및 과정 9

[그림 2-1] 유니버설디자인과 인클루시브 디자인의 비교 20

[그림 2-2] 박물관·미술관에서의 장애인 접근성의 구성과 상관도 23

[그림 3-1] 박물관·미술관의 서비스 체인 54

[그림 4-1] 장애인 접근성 관련 계획 수립 여부 66

[그림 4-2] 장애인 접근성 관련 내부 규정 여부 67

[그림 4-3] 전체운영비 대비 장애인 관련 프로그램 사업 운영예산 비율 67

[그림 4-4] 전체 운영비 대비 장애인 '시설운영'에 소요되는 예산 비율 67

[그림 4-5] 중간관리자의 장애인 업무 담당여부 68

[그림 4-6] 전문분야 지식 습득 직원 여부 68

[그림 4-7] 장애인들이 직원 또는 자원봉사로 지원할 수 있는 정보제공 여부 69

[그림 4-8] 장애인응대 교육 진행 여부 및 내용 69

[그림 4-9] 담당직원의 장애인 접근성관련 정보 숙지 여부 70

[그림 4-10] 자문 시 장애인전문가 포함 여부 70

[그림 4-11] 장애인 접근성 체크리스트 구비여부 70

[그림 4-12] 장애인 이용 만족도 조사 시행 여부 71

[그림 4-13] 전시 안내 보조 및 안내 서비스 제공 여부 72

[그림 4-14] 장애인을 위한 별도 홈페이지 개설여부 73

[그림 4-15] 홈페이지 설계시 웹접근성 고려여부 73

[그림 4-16] 웹 접근성 고려시 홈페이지 설계 방식 73

[그림 4-17] 장애인 관련 프로그램 운영 시 별도 홍보 방식 여부 73

[그림 4-18] 장애인 프로그램 정기적 운영 여부 74

[그림 4-19] 정기적으로 운영하지 않는 경우, 운영방식 74

[그림 4-20] 장애인 프로그램을 운영하지 않는 이유(1순위) 74

[그림 4-21] 장애인 프로그램이 주로 이뤼지는 영역 75

[그림 4-22] 프로그램 운영 시 고려되는 장애 특성(중복응답 허용) 75

[그림 4-23] 프로그램 운영시 대상 인원 조정 방식 76 
[그림 4-24] 장애인 프로그램 대상 연령층(해당항목 모두 체크) 76

[그림 4-25] 장애인 프로그램이 실제로 가장 활발히 진행되는 대상층 77

[그림 4-26] 아웃리치 프로그램 운영여부 77

[그림 4-27] 장애인과 관련한 프로그램 운영 시 운영 방향 78

[그림 4-28] 장애인을 위한 새로운 접객 서비스 개발 여부 78

[그림 4-29] 기관 운영 시, 장애인 친화적 태도 여부 78

[그림 5-1] 사용성과 유니버설디자인/접근성과 인클루시브 디자인 111

[그림 5-2] 전시설명판과의 거리와 높이 117

[그림 5-3] 전시장 조명: 자연광과 인공광 활용 118

[그림 5-4] 장애인의 박물관·미술관 방문여정과 접근성 문제 121

[그림 5-5] 편의시설 상세 지도 126

[그림 5-6] 공간 내 동선을 색으로 표현하여 구분 126

[그림 5-7] 모마 장애인 홈페이지 127

[그림 5-8] 시각장애인의 감각에 대한 설명 영상 127

[그림 5-9] Museum access information Guidelines 조사결과 134

[그림 5-10] 행사 및 프로그램 포스터 136 
장애인 접근성 강화를 위한 박물관-미술관 가이드라인 수립 방향 연구

제1장

서론 



\section{제1절 연구 배경 및 목적}

\section{1. 연구 배경}

' 19 년 기준 전국 국·공립·사립.대학 박물관과 미술관은 1,139 개로 전국문화기반 시설 후에서 가장 많은 수를 차지하고 있다. 2016년 문화 여가활동 조사에 따르면 문화산업군인 영화관람 다음으로 박물관 관람, 전시 관람이 많은 비중을 차지하는 것을 통해 기관 수의 양적 성장만큼 국민에게 박물관과 미술관 방문이 익숙한 문화 활동으로 자리매김하고 있음을 알 수 있다.

사회문화적 환경이 빠르게 변화하고 삶의 질이 중요해지면서 문화 활동은 창작과 향유, 그리고 참여의 방식을 통해 다양한 영역으로 확대되고 있다. 국민의 문화 활 동의 주요한 공간으로서 박물관·미술관에 요구되는 역할 역시 이전보다 훨씬 더 다 양해지고 있다. 김현경(2017b)은 박물관의 이와 같은 역할 확대를 사회적 기능 확 대 측면에서 다루며 '포용적 박물관'이라는 개념을 소개하였다. 포용적 박물관에서 가장 우선되는 가치는 ‘다양한 관람객을 포용하는 것’이다. 여기서 논의되는 관람객 은 기존의 ‘방문자’로서의 다양성뿐만 아닌 잠재적 고객으로서 '비방문자’ 도 포괄하 고 있다.

현재 박물관 정책 영역에서 이와 같은 방문하지 않는 사람들의 경우 '정책 대상' 으로 보기 어렵다. 방문과 비방문의 문제는 개별 기관의 홍보와 마케팅의 영역에서 다뤄지고 있기 때문이다. 다만, 이와 같은 '비방문자'들의 대다수가 경제적 소외계 층이라는 전제하에 경제적 접근성을 개선하기 위한 복지적 성격의 문화정책1)이 추 진되고 있다.

1) 대표적인 정책으로 2008년부터 시행되고 있는 국립 박물관.미술관 무료관람정책을 들 수 있음. 이 정책의 초기 정책목표는 국민의 문화 향수 증진과 소외계층 문화 향수 기회 확대였으며, 현재까지 이 정책목표의 변화 없이 유지되고 있는 상황 
이와 같은 경제적 소외계층 외에, 물리적 접근성의 문제와 밀접하게 관련이 있는 장애인들도 대표적인 비방문자에 속해있다. 물리적 접근성은 사람의 역량에 따라 체감도가 크게 달라질 수 있다. 이에 따라 정부에서는 「장애인 등 편의 증진법」과 같은 장애인의 복지와 권리에 관련된 법 제도를 통하여 사람의 역량에 상관없이 물 리적 접근할 수 있도록 관리하고 있으며, 공공부문의 박물관·미술관은 대표적인 대 상 기관2)이다.

2018년 장애인편의시설 실태조사에 따르면, 장애인편의시설 설치율이 5년 전과 비교해 $12.3 \%$ 가 올랐으며, 조사대상 중 $80.2 \%$ 설치율(적정설치율은 $74.8 \%$ )에 달 하고 있다. 박물관·미술관이 속하고 있는 문화 및 집회 시설3)의 경우 약 $78.9 \%$ 의 적정설치율을 보이며 타 영역보다 비교적 높은 적정설치율을 보인다. 정책 추진 상 황과 관련 시설 설치 비율로만 봤을 때, 비방문자인 장애인의 경제적 접근성과 물리 적 접근성 완화를 위한 정부의 노력(무료관람정책, 장애인편의시설 설치)이 어느 정 도 성과가 있음을 알 수 있다.

반면, 2017 장애인 실태조사에 따르면 장애인의 집 밖 활동 시 불편한 이유는 '장애인 관련 편의시설 부족' 1 순위(49.7\%), 장애인의 지난 1 년간 미술 전시회 관람 경험 '없음' 1 순위(97.5\%)로 나타나 공급되는 정책과 정책 수혜자가 체감하는 성과 간에 괴리가 있음을 알 수 있다.4) 하지만 이 역시도 실질적으로 박물관·미술관 방 문 또는 관람이라는 직접적인 활동에 대한 통계는 아니어서 실태 파악을 하기 어려 운 상황이다. 이와 같은 상황은 정책 공급과 수혜자와 괴리는 더욱 커지게 하는 요 인이 된다.

2019년 문화체육관광부는 〈박물관 및 미술관 진흥 중장기 계획〉(2019 2023)을 통해 장애인에 대한 접근성 강화 정책 사업을 명시하고 이에 대한 후속 조치로서 가이드라인 방향성 마련 필요가 제시되었다. 박물관.미술관 같은 문화공간의 특수 성에 기인한 시설물 설치와 그에 따라 발생하는 서비스 등에 대한 접근을 다룬 종합

2) 장애인등편의법 시행령 제3조에 따른 편의시설 설치 대상 기관

3) 공연장, 집회장, 종교집회장, 관람장, 전시장, 동 식물원 포함. 이중 전시장에는 박물관·미술관·과학관·기념 관·산업전시장·박람회장이 포함됨

4) 2018 장애인 문화예술 활동 실태조사 및 분석연구에서도 장애 유형별로, 청각/언어장애 예술인은 '관람 시 장애인 관련 편의시설 부족'을 많이 꼽았으며(49.8\%), 뇌병변장애 예술인(34.2\%) 및 지체 장애 예술인 (27.4\%)은 '교통 불편’이라는 응답이 상대적으로 많았음. 모두 물리적 접근성에 해당하는 영역에 대한 응답임 
적 성격의 지침과 가이드가 없다고 볼 수 있다. 유니버설디자인을 문화 분야에 접목 하고, 이에 대한 가이드라인을 수립하기 위한 준비 작업의 연구보고서(문화체육관 광부, 2012; 2013)가 발간된 바가 있으나 박물관.미술관 환경을 전문적으로 다룬 장애인 접근성 가이드라인은 공식적으로 발간된 바가 없다. 개별 박물관.미술관 차 원에서도 특정 장애 유형 대상자를 위한 프로그램 개발 연구(국립현대미술관, 2012; 국립한글박물관, 2018; 국립고궁박물관, 2011)는 있으나 장애인이 박물관.미술관 접근에 대한 종합적인 관점이라고 보기 어렵다.

문화적 활동의 경우 시각, 청각, 촉각 등 공감각적인 체험이 필요한 상황에서 문 화시설에서 제공되는 서비스에서 이와 같은 공감각적인 체감이 어려운 장애인에 대 한 접근성에 대한 고민이 많지 않았다는 점은 그간 '향유 확대'와 '소외계층 중심'의 문화 복지적 정책의 양적 성과 이면에 있는 그림자라고 할 수 있다. 실제로 2018 장애인 문화예술 활동 실태조사 및 분석연구 결과에서 시각장애인(예술인 대상)의 문화예술 행사 관람률이 다른 장애 유형보다 상대적으로 낮게 나타나고 있음5)을 알 수 있는데, 관람 활동이 '시각'이 중요한 영역이라는 점에 있어서 이를 보완할 수 있는 정책적 지원이 시급함을 알 수 있다.

\section{2. 연구 목적}

본 연구는 그간 시설 적 측면에서 다뤄져 왔던 접근(access)의 논의를 장애인의 문화향유 관점에서 다시 살펴보는 데서 출발한다. 장애인의 경우 비장애인과 달리 물리적 접근성에 있어서 제약이 큰 것이 사실이다. 그러므로 국내의 장애인 관련 법 제도는 이와 같은 물리적 장벽 해소를 명문화하고 이를 준수하도록 하고 있다. 문화향유 활동은 이와 같은 기본 전제로서의 물리적 장벽 해소 위에 정보 접근성, 서비스 접근성 등이 복합적으로 다뤄져야 한다. '향유'가 가진 사전적 의미에서 기 대어 본다면, 문화를 스스로 누리고 가질 수 있도록 하기 위해서는 물리적 접근성 개선만으로는 충분하지 않다. 이는 장애인뿐만 아니라, 비장애인도 마찬가지이며

5) 뇌병변장애(95.8\%), 자폐성 장애(93.6\%), 청각/언어장애(89.9\%), 지체 장애(87.3\%)보다 시각장애인들은 $52.7 \%$ 의 비율로 상대적으로 낮은 관람률을 보임 
이를 활성화하기 위하여 다양한 요소를 고려해야 한다(최보연·조현성, 2020; 문화 체육관광부, 2019c).

이와 같은 관점에서 본 연구는 박물관·미술관 환경하에서 장애인의 문화향유 활 동이 현재보다 좀 더 나은 방식으로 이뤄질 수 있는 방향을 모색하는 데 목적이 있 다. 구체적으로 접근의 장벽을 개선하기 위해서 박물관·미술관이 해야할 일을 담은 것이 가이드라인의 내용이라고 볼 때, 본 연구에서는 박물관·미술관의 활동이 장애 인들에게 어떠한 방식으로 제공되어야 하는지에 대한 원칙과 방향을 제시하고자 한 다. 가이드라인이 현장에 적용 가능한 실용적인 정보를 제공하기 위해서는 먼저 가 이드라인이 추구하는 목적과 방향이 분명히 설정되어야 한다. 그것이 다수의 공감 과 동의를 얻어낼 수 있는 토대이자 다양한 현장의 실천들을 끌어낼 힘이 되기 때문 이다.

이를 위하여 먼저 현재의 박물관·미술관 현장에서의 장애인 접근성에 대한 상황 을 파악하였다. 또한, 박물관·미술관이 제공하는 정보와 지식이 전달되기 위하여 장 애인들에게 필요한 요소들을 기존에 설계된 해외 박물관·미술관의 가이드라인을 통 하여 살펴보았다. 설정되는 원칙과 방향이 현장에서의 수요와 동떨어지지 않도록 실질적인 서비스 수요자인 장애인과 장애인 관련 활동가들의 의견을 수렴하고 이를 반영하고자 하였다.

최종적으로 본 연구는 기존에 문화향유 정책 내에서 '소외계층' 으로서의 장애인 을 구별 짓는 시선이 아닌 장애인이 일반인과 ‘구별되지 않을 수 있는' 사회 구현을 위한 작은 시작으로서의 목적을 가진다. '다름'이 아닌 '다양성'이 존중될 수 있는 것이 바로 문화예술이 이 사회에 줄 수 있는 중요한 가치라는 점에 있어서 본 연구 에서 도출되는 가이드라인 방향을 통해 장애인을 포함한 더욱 다양한 관람객이 박 물관·미술관을 방문할 수 있도록 하는 데에 본 연구의 의의를 찾을 수 있을 것이다. 


\section{제2절 연구 범위 및 방법}

\section{1. 연구 범위}

\section{가. 시공간적 범위}

본 연구의 공간적 범위는 국내 박물관·미술관이며, 주요 정책 대상으로서 국공립 운영 주체의 기관을 우선으로 두되, 정책 시행에 영향을 고려하여 사립 관을 함께 고려하였다. 현황조사의 경우 기관의 규모와 지역 배분 등을 고려하여 진행하되, 연 평균 관람객 수 5 만 이상의 기관을 대상으로 실시6)하였다. 서비스 관련 사례 조사 의 경우 국내 박물관·미술관에서 전시 및 교육프로그램만 영역별 우수 기획 사업을 대상으로 삼았다. 해외 정책 및 사례 조사의 경우, 국가 단위 정책 추진을 우선순위 로 두되, 영역별로 개별 박물관·미술관의 선례를 참조하여 진행하였다.

시간적 범위는 장애인문화예술 접근성에 대한 정책 환경으로 1989년 「장애인복 지법」 제정 이후를 다루되, 1997년 「장애인·노인·임산부 등의 편의증진 보장에 관 한 법률」(이하 '장애인등편의법'이라 함) 2007 2008년(장애인 문화예술정책 추 진, 「장애인차별금지법」시행, 3 차 장애인종합계획 수립) 이후를 중점적으로 다룬다.

\section{나. 내용적 범위}

내용적 범위는 박물관·미술관 주요 기능을 중심으로 장애인 접근성이 적용될 수 있는 사항을 종합적으로 검토하되, 시설 설치 기준이 아닌 '장애인이 불편 없이 전 시에 접근할 수 있는 환경 조성'에 대한 내용을 중점적으로 다룬다. 국내외 선행연 구 자료들을 통하여 가이드라인의 형식과 범위를 검토하되, 세부적인 지침으로서

6) 장애인 관람객 수가 현저히 낮은 상황에서, 장애인 관련 서비스 및 프로그램 운영현황을 보기 위하여 일정 정도 이상의 운영 규모를 지닌 기관을 대상으로 현황조사 시행 
가이드라인 수립을 위한 기초자료로 활용될 수 있는 원칙과 방향 제시를 주요 골자 로 가이드라인의 방향을 제시하고자 한다.

\section{2. 연구 방법}

본 연구의 방법론으로는 문헌분석, 기관 설문 조사, 이용자 요구 분석을 위한 장 애인, 복지관 관계자 전문가 및 실무자 FGI를 중심적으로 활용하였다.

문헌 조사를 통하여 박물관.미술관 환경에서의 장애인 접근성과 관련한 국내외 제도, 지침 및 기존 연구들을 고찰함으로써 장애인 접근성에 대한 원칙과 기준을 도출하였다. 또한, 다양한 장애인 접근성 강화 관련 해외 사례를 수집하여 영역별로 분석함으로써 국내 적용 가능성을 모색하였다. 장애인 접근성과 관련한 현황을 살 펴보기 위해 연평균 관람객 5 만 이상의 국공립 박물관·미술관을 대상으로 온라인 (또는 이메일 수렴)을 통한 현황조사를 하였다. 현황조사를 통해 구체적으로 파악하 기 어려운 장애인 당사자의 욕구 및 관련 기관의 접근성 현황을 살펴보기 위해 장애 인 개별 맥락적 인터뷰하여 니즈를 파악하고 박물관·미술관 방문에 대한 경험 등에 대한 욕구 및 필요사항(접근 어려움 등 포함)을 깊이 있게 살펴보았다. 이를 브레인 스토밍 방식을 통하여 종합하고 살펴본 국외 가이드라인의 구성 등을 참조하여 장 애인의 접근성을 강화하기 위한 박물관·미술관 가이드라인 수립의 기조와 방향을 제시하였다.

〈표 1-1〉 조사 내용

\begin{tabular}{|c|c|c|c|c|}
\hline 구분 & 기관 현황조사 & \multicolumn{3}{|c|}{ 서비스 요구조사 } \\
\hline 대상 & $\begin{array}{c}\text { 2019년 기준 } \\
\text { 연 관람객 } \\
\text { 5만 이상의 국공립 } \\
\text { 박물관·미술관 }\end{array}$ & $\begin{array}{c}\text { 장애인(단독보행 가능, } \\
\text { 대학교 이상 학력, } \\
\text { 연 4회 이상 박물관. } \\
\text { 미술관 방문) }\end{array}$ & $\begin{array}{c}\text { 장애인 복지관 } \\
\text { 담당자/종합, } \\
\text { 뇌병변, 시각, 청각, } \\
\text { 발달장애 복지관 }\end{array}$ & $\begin{array}{c}\text { 관련 전문가 및 } \\
\text { 박물관/미술관 실무, } \\
\text { 복지관 실무, 박물관 및 } \\
\text { 장애인 전문가 }\end{array}$ \\
\hline 표본 수 & $\begin{array}{c}\text { 모집단(222개) 중 } \\
115 \text { 개 유효표본 수집 }\end{array}$ & 2인 & 10인 & 8인 \\
\hline $\begin{array}{l}\text { 기간/ } \\
\text { 횟수 }\end{array}$ & $\begin{array}{c}\text { 2020년 6월 9일 } \\
\text { 7월 15일 }\end{array}$ & 총 2회 & 총 4회 & 총 4회 \\
\hline 방법 & 온라인 웹 설문 & 1:1 면담 & $\mathrm{FGI}$ & FGI/ 1:1인터뷰 \\
\hline
\end{tabular}


[그림 1-1] 연구의 수행방법 및 과정

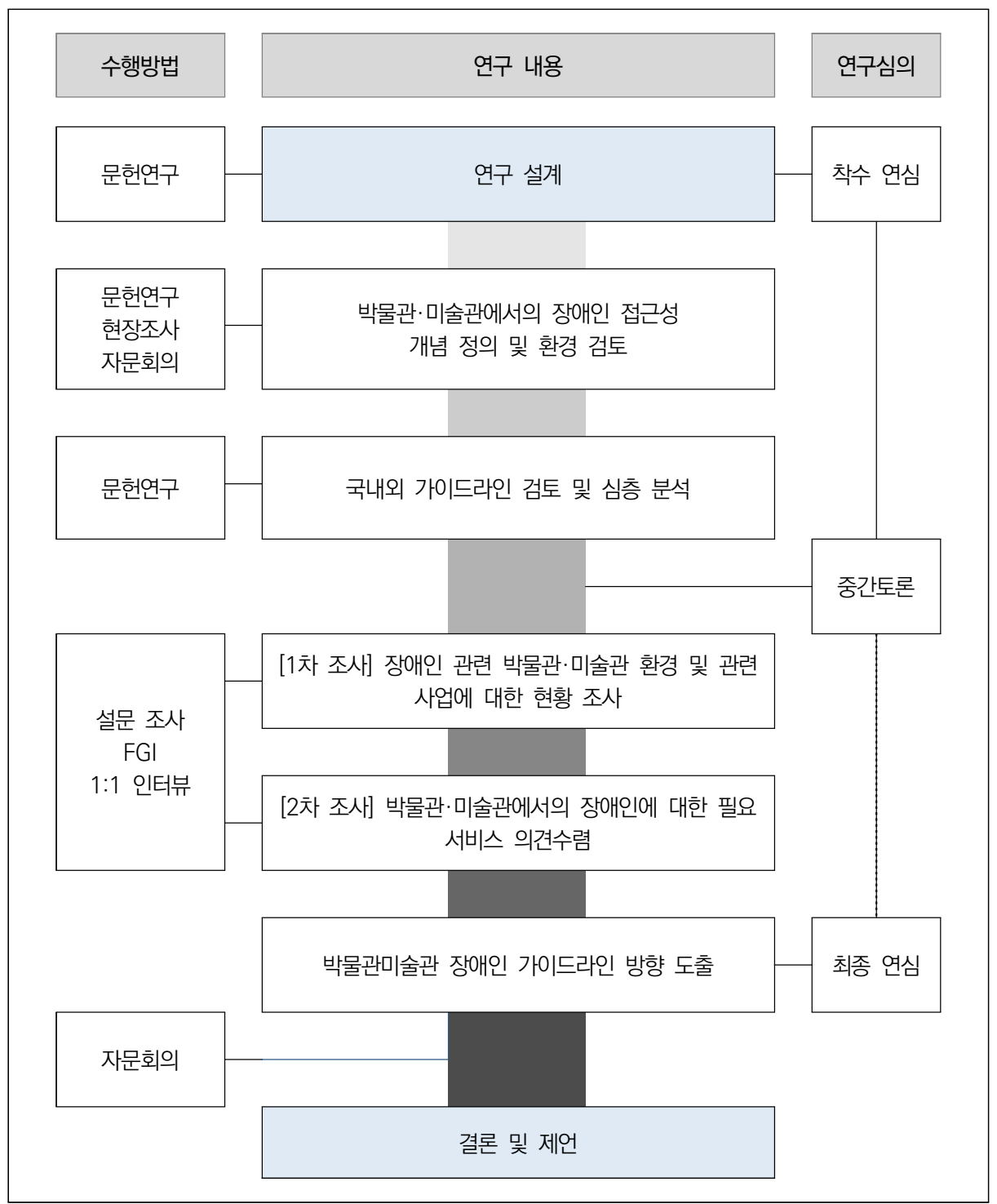



장애인 접근성 강화를 위한 박물관-미술관 가이드라인 수립 방향 연구

제2장 박물관-미술관에서의 장애인 접근성 개념 및 범위 



\section{제1절 박물관·미술관에서의 장애인 접근성의 개념}

\section{1. 장애인의 정의 및 현황7)}

\section{가. 장애인의 정의 및 장애 인정 범위}

1975년 UN에서 발표한 장애인 권리선언에 따르면 장애인은 “선천적이든 후천적 이든 신체적, 정신적 능력의 불완전으로 인하여 일상의 개인적 또는 사회적 생활에 서 필요한 것을 확보하는데 자기 자신이 완전하게 또는 부분적으로 할 수 없는 사람 을 의미" 한다. ICIDH8)는 의학적 의미의 개념에서 손상, 기능제약(Disabilities), 사회적 불리(Handicaps) 등의 개념으로 확장하여 장애를 설명함으로써 신체적 손 상이나 기능제약과 함께 사회적으로 불이익을 받는 상황을 강조하고 있다.

우리나라 「장애인복지법」에서는 장애인을 "신체적, 정신적 장애로 오랫동안 일상 생활이나 사회생활에서 상당한 제약을 받는 자"로 정의하고 있다.

등록 장애인은 장애인복지법 제 2 조의 기준에 해당하는 장애인이 동법 제 32 조에 의하여 시·군·구청장에게 등록을 한 자를 말하며, 등록 장애인현황은 15 개 장애인 유형의 기준에 적합하여 행정기관에 등록된 장애인을 의미한다.9)

장애는 크게 신체적 장애와 정신적 장애로, 신체적 장애는 다시 외부 신체 기능의 장애와 내부기관의 장애로 구분할 수 있다. 현재 총 15 개의 장애 유형이 존재하며 이는 2000년 1차 장애범주 확대(뇌병변, 자폐, 정신, 신장, 심장 5종 추가), 2003년 2차 장애범주 확대(안면변형, 장루, 간, 간질, 호흡기 장애)의 결과이다. 총 15 개 유

7) 보건복지부(2019), 『2019년도 등록장애인 현황』, 보건복지부 보도자료(2020.04.) 내용 참고

8) 장애에 대한 일반적인 정의는 세계보건기구(WHO)에서 제시하고 있는데, 1980년에 채택된 ICIDH (International Classification of Impairments, Disabilities and Handicaps)와 2001년에 승인된 ICF(International Classification of Functional, Disability and Health)가 있다.

9) 장애인은 다음 각 호의 어느 하나에 해당하는 자임: 「장애인복지법 시행령 제 2 조 및 별표 1 에 해당하는 자, 「국가유공자 등 예우 및 지원에 관한 법률 시행령」 제14조제 3 항 및 별표 3 에 따른 상이등급 기준에 해당하는 자 
형의 장애인은 다음가 같다.

- 지체장애인, 뇌병변 장애인, 시각장애인, 청각장애인, 언어장애인, 지적장애인, 자페성 장애인, 정신장애인, 신장장애인, 심장장애인, 호흡기장애, 간장애인, 안면장애인, 장루·요루 장애인, 뇌전증장애인

2019년말 기준 등록 장애인 수는 총 261만 8천명이고, 전체인구대비 5.1\%이다. 15 개 장애유형 분석 결과, 지체(122만 3,000명, 46.7\%), 청각(37만 7,000명, 14.4\%), 시각(25만 3,000명, 9.7\%), 뇌병변(25만 2,000명, 9.6\%) 순으로 비율이 높았으며, 가장 낮은 유형은 뇌전증(7,000명, 0.3\%), 심장(5,000명, 0.2\%), 안면(3,000명, 0.1\%) 장애 순으로 나타났다. 65세 이상 장애인 인구가 48.3\%로 점차 고령화 사회로 접 어듦에 따라 장애노인의 지속적인 증가하고 있음을 알 수 있다(보건복지부, 2019).

\section{나. 특수교육대상자의 정의 및 선정 기준}

“특수교육 대상자”란 교육장 또는 교육감이 다음의 어느 하나에 해당하는 사람 중 특수교육을 필요로 하는 사람으로 진단·평가하여 선정된 사람을 말한다(「장애인 등에 대한 특수교육법」 제2조제3호 및 제15조). 특수교육대상자의 경우 장애 유형 구분과 달리「장애인 등에 대한 특수교육법 시행령」 제 10 조 및 별표에 의거하여 대 상자를 선정한다. 특수교육대상자의 법적 분류는 다음과 같다.

〈표 2-1〉 특수교육대상자와 장애인복지법의 장애인 유형

\begin{tabular}{|c|c|c|}
\hline \multirow{2}{*}{ 장애인등에 대한 특수교육법 } & \multicolumn{2}{|c|}{ 장애인복지법 } \\
\hline & 신체외부적 장애 & 신체 내부적장애 \\
\hline \multirow{3}{*}{$\begin{array}{c}\text { 시각장애, 청각장애, 정신지체, 지체장애, } \\
\text { 정서행동장애, 자폐성장애, 의사소통장애, } \\
\text { 학습장애, 건강장애, 발달지체, 그밖에 } \\
\text { 대통령령으로 정하는 장애 }\end{array}$} & $\begin{array}{c}\text { 지체장애, 뇌병변장애, } \\
\text { 시각장애, 청각장애, } \\
\text { 언어장애, 안면장애 }\end{array}$ & $\begin{array}{c}\text { 신장장애, 심장장애, } \\
\text { 호흡기장애, 간장애, } \\
\text { 장루/요루장애, 간질장애 }\end{array}$ \\
\hline & \multicolumn{2}{|c|}{ 정신적 장애 } \\
\hline & \multicolumn{2}{|c|}{ 지적장애, 정신장애, 자폐장애 } \\
\hline
\end{tabular}

출처: 국가법령정보센터(2020.08.15. 접속기준) 
우리나라의 경우, 2019 년도 특수교육대상자 규모는 전체 학생의 $1.4 \%$ 이다. 이 중, 지적장애가 전체 특수교육대상자의 $53.4 \%$ 를 차지하고 있다. 규모 순으로는 지 적장애, 자폐성장애, 지체장애, 발달지체 순이다(이대식, 2020).

\section{2. 박물관·미술관에서의 '장애인 접근성'의 의미}

\section{가. 박물관·미술관 접근성}

'접근성'은 사전적으로 발생한 위치로부터 특정한 장소 또는 시설로 접근할 가능 성을 말한다. ${ }^{10)}$ 최근 디지털 영역이 확장됨에 따라 그 정의와 범위가 변화하고 있 지만, 전통적으로 박물관·미술관은 장소성에 기반을 둔 '특정한 공간'이며, (공공 혹 은 민간) 시설이다. 이와 같은 관점에서 박물관.미술관 접근성은 일반적으로 우리가 출발하고자 하는 위치에서부터 그 장소까지 도달하기 위한 '물리적 접근성'을 주로 다루고 있으며, 이동방식 또는 이동의 편의성과 밀접한 상관관계를 맺는다.

국어의 사전적 의미와 달리, 영어 Accessibility는 장소에 국한되어 사용되기보 다 (어떠한 서비스, 장소, 상태, 환경 등) 접근될 가능성, 방식, 접근이 허용되도록 함을 의미한다. 이에 '사용 가능(상태)' 함을 의미하는 Usability와 비교되기도 하는 데 Usability가 사물, 기구 등에 사용되는 것에 반하여 Accessbility가 좀 더 넓은 의미를 담고 있다고 볼 수 있다. 최근 웹상의 사용자 인터페이스, 디자인과 관련하 여 사용되는 '접근성'의 범위는 사용자가 가진 특징(신체적, 나이, 지식수준 등)을 고려하여 가능한 많은 사용자가 불편 없이 이용하도록 제품, 서비스를 만들어 제공 하고 이를 평가할 때 사용되는 용어로서 앞선 국어 사전적 의미보다 적용 범위가 넓다. 이처럼 '접근성'의 접두어로서 '웹’ 외에도 '문화', '의료' '디자인' 등이 많이 쓰이고 있다.11) 이때의 '접근성'은 물리적 접근성 외에도 행위 또는 그곳에서 발생 하는 내용 또는 서비스(문화예술, 의료 행위 등)에 대한 접근성을 포괄한다.

이에 문화시설로서 박물관·미술관 접근성은 '문화 접근성' 측면에서 물리적 접근 성 외에도 그 안에서 벌어지는 모든 문화예술 활동에 전반에 대한 접근을 가능하도

10) 표준국어대사전

11) 우리말샘 https://opendict.korean.go.kr/main(2020.09.14. 접속기준) 
록 하는 범위에 다뤄져야 한다. 또한, 박물관·미술관을 '방문' 하는 행위를 관광의 차원에서 볼 수 있으며, 이때의 박물관·미술관 접근성 범위는 훨씬 넓어질 수 있다. 관광은 관광자원(시설)의 인식, 관광상품의 구매(예약), 이동, 관광행위 등 다양한 요소로 구성되는데(한국관광공사, 2015) 박물관·미술관 관람이라는 관광행위에 접 근할 수 있도록 하는 모든 요소를 '박물관·미술관 접근성'의 범위로 볼 수도 있다.

살펴본 바와 같이 박물관·미술관 접근성은 그곳에서 이뤄지는 모든 행위에 대한 접근 가능성이라고 볼 때 박물관·미술관에 '어떻게' 다가올 수 있게 하느냐는 장애 인뿐 아니라 모든 계층과 대상을 아우른다. 영국의 박물관·도서관 및 아카이브 협의 회에서 2000년 발간한 「re:sourcee-Disability Directory for Museum and Galleries」에서는 박물관·미술관의 접근 방해 요소를 다음의 〈표 2-2〉로 보았다.

〈표 2-2〉 접근성의 유형에 따른 박물관-미술관 방문객 개발 관점 적용

\begin{tabular}{|c|c|c|}
\hline 구분 & 고려사항 & 방문객 개발의 관점 적용 예 \\
\hline $\begin{array}{c}\text { 물리적 접근 } \\
\text { (Physical access) }\end{array}$ & $\begin{array}{l}\text { - 시설 환경이 물리적으로 접근 가능 } \\
\text { 한가? }\end{array}$ & $\begin{array}{l}\text { - 조명 추가 설치, 핸드레일, 장애인용 의자, } \\
\text { 엘리베이터 등 }\end{array}$ \\
\hline $\begin{array}{c}\text { 감각적 접근 } \\
\text { (Sensory access) }\end{array}$ & $\begin{array}{l}\text { - 전시와 이벤트 프로그램, 편의시설을 } \\
\text { 시각 또는 청각에 손상이 있는 사람 } \\
\text { 들이 활용할 수 있는 거? }\end{array}$ & $\begin{array}{l}\text { - 만져서 이용 가능한 도구의 제공 } \\
\text { - 다양한 방식(자막이 있는, 시각적 설명이 } \\
\text { 있는 등)이 적용된 전시설명 도구 제공 } \\
\text { - 청각장애인을 위한 소리 증폭 시스템 제공 }\end{array}$ \\
\hline $\begin{array}{c}\text { 지적 접근 } \\
\text { (intellectual access) }\end{array}$ & $\begin{array}{l}\text { - 배경지식이 많지 않은 사람들을 배제 } \\
\text { 하고 있지 않은가? } \\
\text { - 습득능력 장애(learning disabilities) } \\
\text { 가 있는 사람들이 우리의 서비스를 } \\
\text { 이용할 수 있는가? }\end{array}$ & $\begin{array}{l}\text { - 전시 구성단계 있어 새로운 관람객의 의견 } \\
\text { 을 듣고 이를 반영하는 것 } \\
\text { - 전시를 기획 단계에서, 다양한 관람객의 } \\
\text { 수준별 이해도에 대한 평가 기준을 세움 }\end{array}$ \\
\hline \begin{tabular}{c|} 
경제적 접근 \\
(Financial access)
\end{tabular} & $\begin{array}{l}\text { - 입장료가 수입이 낮은 사람들의 방문 } \\
\text { 을 어렵게 하는가? } \\
\text { - 샵과 까페에서 판매되는 아이템들이 } \\
\text { 가족들이 소비할만한 수준으로 가격 } \\
\text { 이 책정되어있는가? }\end{array}$ & $\begin{array}{l}\text { - 특정한 날 등에 대한 무료입장을 제공하고 } \\
\text { 이러한 적용을 널리 알리는 것 } \\
\text { - 박물관을 지역의 다양한 공동체와 연결하 } \\
\text { 는 것 } \\
\text { - 방문 교통수단을 무료로 제공하는 것 }\end{array}$ \\
\hline $\begin{array}{c}\text { 정서적/태도적 접근 } \\
\text { (Emotional/ } \\
\text { attitudinal access) }\end{array}$ & $\begin{array}{l}\text { - 우리 기관은 새로운 방문자를 환대하 } \\
\text { 는 환경인가? } \\
\text { - 우리 직원은 다양한 관람객(diversity) } \\
\text { 에 대한 열린 태도로 임하는가? }\end{array}$ & $\begin{array}{l}\text { - 직원 교육 } \\
\text { - 새로운 방문객들에게 기관의 환대 노력을 } \\
\quad \text { 보여줄 수 있는 특별한 이벤트 등 개최 }\end{array}$ \\
\hline $\begin{array}{l}\text { 의사결정에 대한 } \\
\text { 접근(Access to } \\
\text { decision-making) }\end{array}$ & $\begin{array}{l}\text { - 우리 기관은 새로운 관람자의 가능성 } \\
\text { 과 가치에 대해서 외부 관계자들에게 } \\
\text { 컨설팅을 받고 있는가? }\end{array}$ & $\begin{array}{l}\text { - 관람객과의 파트너쉽 형성을 위한 프로젝트 } \\
\text { - 자문위원단 구성 }\end{array}$ \\
\hline
\end{tabular}




\begin{tabular}{|c|c|c|}
\hline 구분 & 고려사항 & 방문객 개발의 관점 적용 예 \\
\hline $\begin{array}{l}\text { 정보에 대한 접근 } \\
\text { (Access to } \\
\text { information) }\end{array}$ & $\begin{array}{l}\text { - 기관에 대한 홍보가 효과적으로 새로 } \\
\text { 운 관람객과 소통하고, 그들에게 닿 } \\
\text { 아있는가? }\end{array}$ & $\begin{array}{l}\text { - 새롭고, 접근가능한 마케팅 네트워크, } \\
\text { - 커뮤니케이션 방법의 개발 } \\
\text { - 홍보물을 생산할 때, 다양한 언어로 제공 } \\
\text { - 직관적으로 이해하기 쉽게 만들어진 홍보물 }\end{array}$ \\
\hline $\begin{array}{c}\text { 문화적 접근 } \\
\text { (cultural access) }\end{array}$ & $\begin{array}{l}\text { - 컬렉션과 전시디스플레이, 다양한 행 } \\
\text { 사가 우리의 타겟 고객인 관람자의 } \\
\text { 삶과 관심사를 반영하고 있는가? }\end{array}$ & $\begin{array}{l}\text { - 새로운 수집 정책의 수립 } \\
\text { - 적정한 해석이 담겨진 전시디스플레이 재 } \\
\text { 배치 }\end{array}$ \\
\hline
\end{tabular}

자료: R. Sandell \& J. Dodd,. Alison Coles (ed.) (1998:14) 내용 재인용 및 연구자 번역

이상에서 언급된 박물관·미술관 접근 장애 요인은 물리적 접근에서부터 문화적 접근성의 이슈를 모두 아우르고 있다. 이에 덧붙여 박물관·미술관의 역할과 기능이 확대됨에 따라, 최근에는 의사결정에 대한 접근, 정보에 대한 접근, 문화적 접근 장 벽 역시 박물관·미술관에서 다뤼야할 중요한 이슈로 볼 수 있다. 또한 디지털 환경 변화에 따라 온라인 영역의 중요성이 확대되고 있으며 박물관·미술관 환경 역시 이 를 중심으로 빠르게 변화하고 있다(류정아·김현경, 2016). 이에 박물관·미술관에서 웹 접근성의 문제는 큰 범위의 정보 접근의 차원에서 정보에 대한 수집과 습득, 그 격차 해소가 필요하다는 의미에서 중요하게 다뤄져야 할 영역이다.

\section{나. 박물관-미술관에서 '장애인 접근성' 의미}

국제박물관협회(ICOM)에서는 1980년 멕시코시티에서 개최된 제13회 ICOM 총회의 결의안으로 박물관의 '장애인에 대한 책무'(Resolution No. 2: Museum Responsibilities Towards the Handicapped)를 채택하였는데 세부 내용은 다 음과 같다.

- 사회에 봉사하는 기관으로서 모든 종류의 박물관은 가능한 한 시설을 제공하고 일자리 기회를 창출하여 장애인에게 접근할 방법을 고려해야 한다.

- 장애인의 훈련 및 교육을 지원한다는 것

- 관련 문제를 더욱 잘 이해하는 데 이바지하기 위해 장애인과 관련된 자료를 수 집, 문서화 및 전시하는 행위 
- 그들은 이 작업에 있는 모든 그룹의 사람들을 통합하기 위한 프로그램을 시작 하는 것을 고려해야 한다.

- 장애인에게 무료입장을 허가한다.

결의안에 따르면 박물관에서의 '장애인 접근성'(Accessbility)은 앞서 살펴본 '박 물관·미술관 접근성' 요소에서 단순한 물리적 접근성뿐 아니라, 관광행위와 마찬가 지로 방문행위에 연계되는 모든 요소와 연관되어있음을 알 수 있다. 더 나아가 박물 관-미술관에서 벌어지는 다양한 이슈에 대하여 장애인이 적극적으로 참여하고 접근 할 수 있도록 하는 좀 더 적극적인 의미의 박물관의 장애인 접근에 대한 의무를 강 조하고 있음을 알 수 있다. 선언문이 채택된 1980년대는 박물관에 대한 새로운 관 점이 대두되던 시기였다. 구도심의 문화적 재생을 이끌거나 도시의 주요한 관광지 로서 박물관의 역할이 중요해지는 등 새로운 역할과 임무가 주어짐에 따라 박물관 은 '옛것'이 아닌 '현대적인' 우리의 일상과 가까워졌다.

이후 다양한 문화적 활동이 복합적으로 이뤄지는 공간으로서 박물관의 기능이 확 대되었고, 우리 사회에서 중요한 문화시설로 자리 잡았다.

이와 같은 상황 속에서 유물에 귀속된 공간으로서 전통적인 방식이 아닌 새로운 관점으로 박물관에 대한 독자적인 사회적 역할에 대한 논의가 활발해졌다. 비영리 기관으로서 박물관의 서비스가 사회의 다양한 계층 모두에게 적용될 수 있도록 해 야 한다는 의미의 사회 포용적 역할이 확대되고 있다(김현경, 2017b). 이는 박물 관·미술관의 활동이 방문하는 사람들 중심으로 서비스를 제공하는 소극적인 방식에 서 벗어나 적극적으로 사회와 연결되어야 함을 강조한다. 사회에서 누구도 “배제”되 지 않게 하려고 문화기관이 적극적인 임무를 수행할 수 있으며, 장애인도 역시 이와 같은 문화시설의 다양한 서비스를 적극적으로 누릴 수 있도록 해야 한다고 보았다 (DCMS, 1999).

최근에는 박물관이 시대적 위기에 대한 윤리적 선택지로서 첨예한 사회 문제에 적극적으로 개입하고 사회정의 실현을 위한 활동가로서 자기 정체성을 재정립하려 는 '박물관 행동주의'(Museum Activism)에 대한 논의가 이뤄지고 있다(박소현, 2017). 『Museum Activism」에 따르면, "박물관 행동주의란 불평등, 불공정, 환경 의 문제 등을 해결하기 위하여 지적이면서 시민 공동의 자원을 중심으로 그간 박물 
관에서 다뤄오지 않았던 가능성을 살펴보고자 하는 운동”의 일환이라 할 수 있다 (Jane \& Sandell, 2019). 박물관의 공공성 영역을 사회적 윤리 차원으로까지 확장 하고 있는 박물관 행동주의는 '장애인의 접근성'을 좀 더 적극적으로 박물관에서 해 소하고 이에 대한 새로운 관점의 접근이 필요함을 강조하고 있으며, 다음과 같은 질문들을 던지고 있다(Kudlick \& Ludy, 2019).

- 역사적으로 박물관과 미술관의 컬렉션과 전시물에서 장애인과 장애인 관련 주 제가 어떻게 표현되었는가?

- 장애인의 편견과 선입견에 해소를 위해 박물관에서의 새로운 시도는 장애 권리 의 광범위한 발전, 장애 연구의 논쟁, 공공 역사 및 대중 매체에서의 장애인에 대한 관행을 변화시키는데 어떻게 관련될 수 있는가?

- 박물관·미술관 컬렉션 수집과 구매 등에 장애인에 대한 역사를 조사하고 편견 에 대응하기 위한 어떠한 노력을 할 수 있는가?

- 장애인과 비장애인 모두를 위한 관람방식은 어떠하며, 비장애인 지배적인 표현 방식에서 벗어나기 위한 어떠한 노력이 가능한가?

멕시코 ICOM 총회의 결의안 채택 이후 40년, 박물관·미술관은 이전보다 훨씬 더 다양하고 복잡하고 거대해졌다. 이는 비단 물리적 공간의 확장만을 의미하는 것 이 아니며 우리의 삶과 연결되어 박물관·미술관의 역할과 기능이 더욱 중요하고 커 지고 있다.12) 이와 같은 상황에서 박물관·미술관에서의 장애인 접근성은 그 시절 '선언'에 머무르지 않으며 박물관·미술관 새로운 정의에 따른 주요한 이슈로써 논의 되고 있다고 볼 수 있다.

12) ICOM 2019 교토 대의회에서 발표된 박물관 정의 https://icom.museum/en/activities/standardsguidelines/museum-definition/(2020.09.14. 접속기준) 


\section{3. 박물관·미술관에서의 '장애인 접근성'의 유형}

특정 대상으로서 장애인의 접근성은 장애인의 특성을 고려하는 것이 우선이 되어 야 한다. 다른 한편으로는 장애인을 '특수한' 대상으로 분리되지 않도록 고려해야 하 는 요소이기도 하다. 이에 장애인 접근성의 강화는 박물관.미술관의 일반적인 접근성 을 포괄하되, 장애인에게 필요한 요소를 중요도에 따라서 우선순위를 다르게 설정하 는 방식으로 다뤄져야 한다. 이는 '유니버설디자인(universal design)' 접근보다 '인 클루시브 디자인(inclusive design)13' 접근에 좀 더 가까운 개념으로 봐야 한다.

'유니버설디자인'과 '인클루시브 디자인'은 장애인이 시설이용에 불편함이 없도 록 이용자 중심의 기본 원칙으로 논의되는 대표적인 원칙이다. 성별, 연령, 국적, 문화적 배경, 장애의 유무에 상관없이 모든 사회 구성원들에게 친화적인 디자인을 제공하고, 사회적 약자와 강자가 공존할 수 있는 생활환경을 구성한다는 목표는 동 일하고 거의 유사한 의미로 쓰이지만. 미국을 중심으로 유니버설디자인이 많이 쓰 이며, 유럽을 중심으로 인클루시브 디자인이 좀 더 많이 쓰이는 개념으로 볼 수 있 다(Kim, 2015).

[그림 2-1] 유니버설디자인과 인클루시브 디자인의 비교

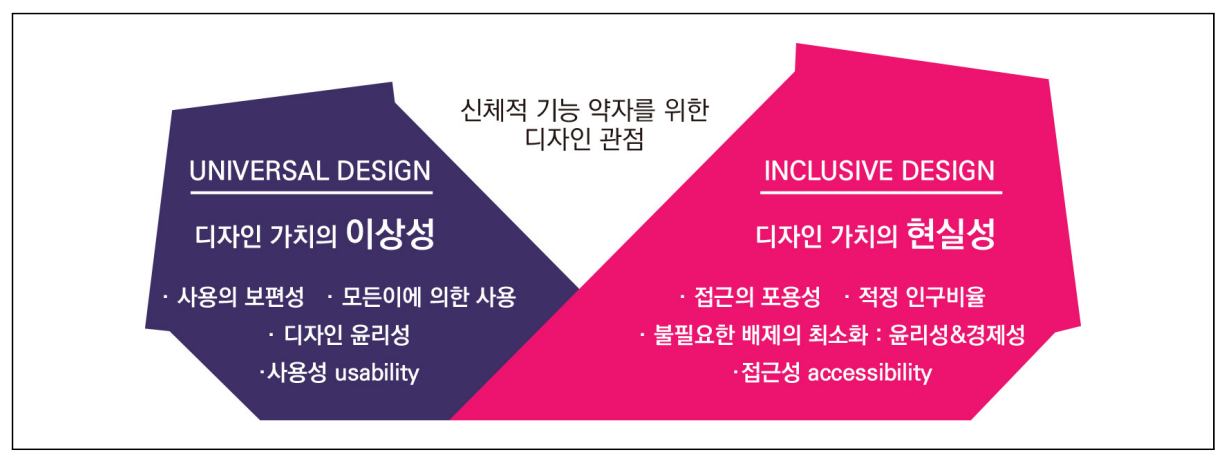

출처: Kim, T. (2015). Characteristics of Inclusive Design and Its Meaning in the Future Society. Archives of Design Research, 28(2), 137-151

각각은 '보편'(universal)과 '포괄'(inclusive)의 차이에서 볼 수 있듯이, 유니버 설디자인의 경우 정상인 위주의 제품과 환경을 차이가 있는 사람도 같이 사용할 수

13) 여기서 표현되는 디자인은 사물에 적용되는 제품 디자인은 물론 서비스 디자인의 영역까지 포괄하는 범위임 
있다는 개념에서 출발하였고, 인클루시브 디자인의 경우 주 사용자를 중심으로 설 계하되 그러한 특성을 보이지 않은 사용자들도 포괄한다는 의미에서 주 사용자를 중심이 좀 더 강한 개념으로 볼 수 있다.14) $\mathrm{Kim}(2015)$ 에 따르면, 인클루시브 디자 인은 "가능한 많은 사람"을 대상으로 하는 가치의 현실성을 지향한다. 포용적 디자 인의 정의에서 나타나는 특징적 표현은 “가능한 많은 사람", “최대한 많은 사람"이 다. 이것은 '많은 사람이 사용할 수 있는' 양적 포용성과 '다양한 사람이 쓸 수 있는' 질적 포용성을 의미하는 것이며 이를 통해 결국 경제적 포용성까지 연결된다. (Kim, 2015:143)

국내에서 장애인 편의 시설과 관련하여 유니버설디자인이 보편적으로 활용되고 있으나, 본 연구의 접근성이 물리적 접근성 외에 장애인을 중심으로 한 박물관.미술 관의 다양한 관람객 중 하나로서 장애인을 보고 그들의 문화시설에 대한 실질적 이 용과 질적 포용성을 포괄한다는 차원에서 '인클루시브 디자인' 접근을 우선에 두고 자 한다.

또 다른 전제는 접근성의 장벽이 복합적으로 발생한다는 점이다. 박물관·미술관 방문이 특정 접근성이 해소된다고 해서 즉각적으로 증가한다고 보기 어렵다. 이는 비장애인도 마찬가지이다(최보연·조현성, 2020; 문화체육관광부, 2019c). 이에 본 연구에서는 앞서 논의된 박물관·미술관의 접근성의 유형에 새롭게 변화된 환경에서 중시되는 요소(온라인 환경, 의사결정 및 문화적 접근)를 반영하고 박물관의 주요 4가지 요소인 공간(온라인 공간 포함), 인력, 컬렉션, 관람객을 기준(다니엘 지로디, 1996) 으로 하여 장애인 접근성의 유형을 〈표 2-3〉과 같이 구분하고자 한다.

장애인은 비장애인과는 다르게 '물리적 접근의 장벽'이 우선적으로 해소될 필요 가 있다. 이러한 물리적 접근의 장벽은 '감각적 접근'과 '이동 편의성'과도 밀접한 연관을 맺으며, 시각 감각을 전제로 하는 '웹 접근성'도 물리적 접근성으로 해소 차 원에서 논의가 이뤄져야 한다. 장애인을 위한 현장에서의 편의시설이 제공되듯이, 웹상에서도 장애인 이용 편의를 고려한 인터페이스가(인프라) 제공되어야 한다. 이 는 '인클루시브 디자인'관점으로서 '장애인을 위한 웹 페이지'가 개설되었을 때 주 과녁인 장애 유형별 사용자의 이용을 우선 목적으로 하되, 이 장애인용 웹 페이지

14) Univ.Cambrige, "What is inclusive design" (2020.09.14. 접속기준) http://www.inclusivedesigntoolkit.com/whatis/whatis.html 
를, 비장애인들도 이용할 수 있게 한다는 점에서 모든 사람을 위한 보편적인 서비스 설계를 우선으로 두는 유니버설디자인과는 차별점을 갖는다.

〈표 2-3〉 본 연구에서 다루고자 하는 박물관-미술관 장애인 접근성 유형

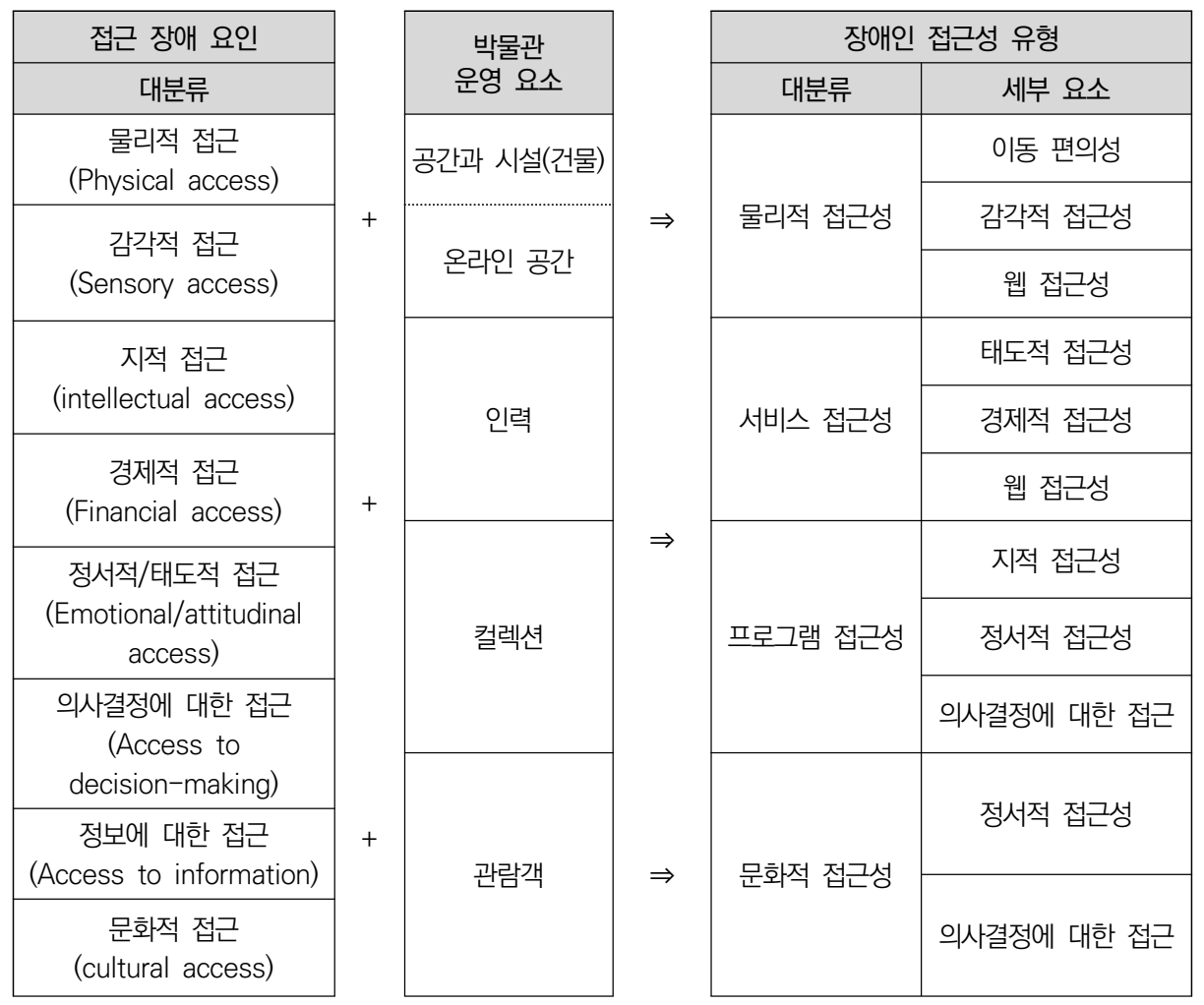

서비스와 프로그램 접근성은 박물관·미술관의 주요 기능이자 박물관·미술관을 방 문하는 목적이다. 방문 목적을 성취하도록 하는 것이 본 연구에서 다루는 접근성 강화 의 핵심이다. 서비스 접근성은 경제적 접근성, 태도적 접근성 그리고 웹 접근성으로 나뉜다. 물리적 접근성에 포함된 웹 접근성과는 달리 서비스 접근성의 하위로서 웹 접근성은 정보의 습득과 선별의 의미가 있다. 박물관·미술관의 주요 기능은 전시와 교육, 그리고 컬렉션 수집(관리)이다. 이러한 주요 기능에 대하여 '프로그램 접근성'을 구분하여 정서적, 지적 접근성을 포괄하고 그 외의 박물관. 미술관의 다양한 사업 등 에 장애인의 목소리를 담을 수 있는 의사결정 접근성을 포함하고자 한다. 이는 앞서 논의한 ‘박물관 행동주의’ 관점에서의 장애인의 적극적인 활동 참여를 전제로 한다. 
[그림 2-2]의 보는 바와 같이 물리적 접근성은 정보접근성과 문화적 접근성을 아 우르고 두 요소에 영향을 미치는 기반(basement)요소로 보았다. 박물관·미술관에 서의 경험의 시작은 물리적 장벽을 넘어 시설 방문을 하는 시점에서부터 실질적으 로 시작되며 장애인의 경우 이동 동선은 물론 서비스 전반에 물리적 장벽이 없어야 서비스를 이용할 수 있기 때문이다.

[그림 2-2] 박물관·미술관에서의 장애인 접근성의 구성과 상관도

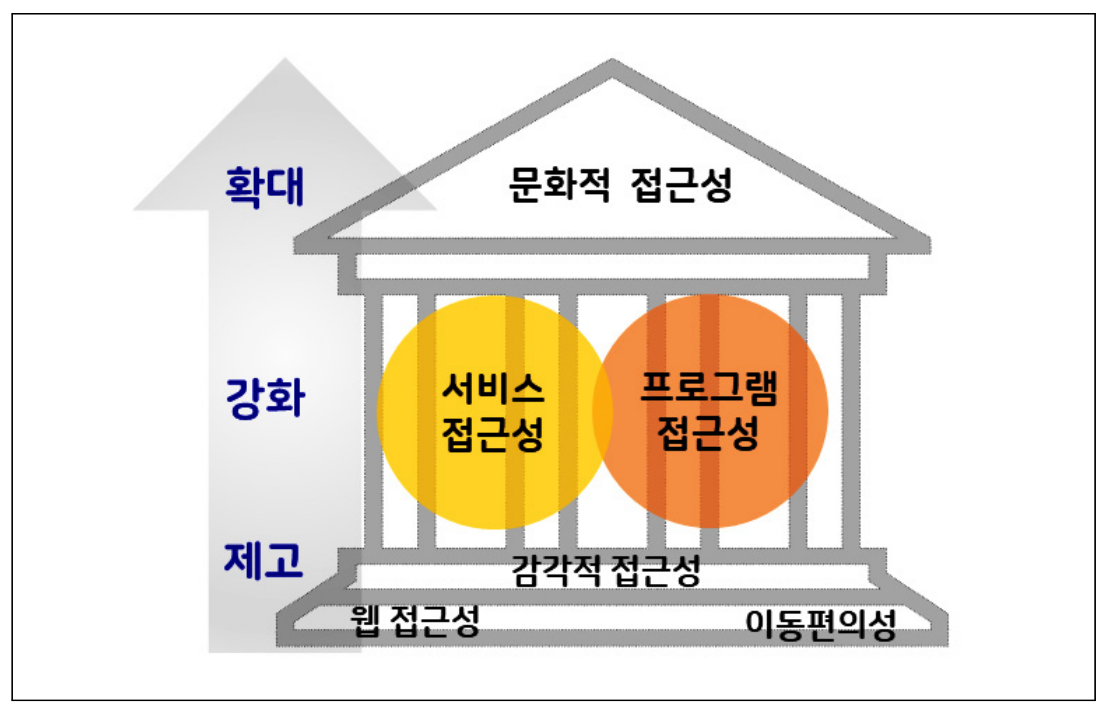

장애인 접근성에서 '문화적 접근성'은 중요한 의미가 있다. 이는 '장애인들이 동 등한 정치적 권리들을 행사할 수 있도록 기회를 보장하며, 그들이 문화생활, 레크리 에이션, 여가생활 등을 비장애인과 동등한 입장에서 참여할 수 있도록 보장함'을 명 시한 〈UN 장애인 권리협약〉에 기초하여 장애인이 박물관·미술관을 다양한 문화생 활 참여 공간으로 여기고 적극적으로 이용할 수 있도록 점진적으로 확대되어야 할 접근성 영역이다.

정서적으로 장애인들이 '친화적' 으로 느낄 수 있는 환경으로서(정서적 접근성), 장애인들이 가진 관심사와 그들의 목소리를 반영할 수 있는 공간(의사결정 접근성) 으로서 박물관-미술관이 위치할 때에 이러한 문화적 접근성이 확대될 수 있다. 


\section{제2절 국내 장애인 박물관·미술관 접근성 관련 법제도}

\section{1. 장애인의 박물관·미술관 접근성 관련 법률}

「장애인복지법」 제 4 조 장애인의 권리 2항에 따르면 "장애인은 국가-사회의 구성 원으로서 정치·경제·사회·문화, 그 밖의 모든 분야의 활동에 참여할 권리를 가진 다.”라고 명시되어있다. 또한 동법 제 28 조(문화환경 정비 등)에 따르면 “국가와 지 방자치단체는 장애인의 문화생활, 체육활동 및 관광 활동에 대한 장애인의 접근을 보장하기 위하여 관련 시설 및 설비, 그 밖의 환경을 정비하고 문화생활, 체육활동 및 관광 활동 등을 지원하도록 노력하여야 한다”라고 명시되어있다.

마찬가지로, 「장애인차별금지 및 권리구제 등에 관한 법률 제 24 조(문화예술 활동 의 차별금지) 와 제 24 조의 2 (관광 활동의 차별금지)에 따르면 편의 제공과 적극적으 로 참여할 수 있는 시책 강구를 명시하고 있다.

\section{제24조(문화·예술 활동의 차별금지)}

(2)국가와 지방자치단체 및 문화·예술사업자는 장애인이 문화·예술 활동에 참여할 수 있도록 정당한 편의를 제공하여야 한다..

(3)국가 및 지방자치단체는 장애인이 문화·예술시설을 이용하고 문화·예술 활동에 적극적으로 참여 할 수 있도록 필요한 시책을 강구하여야 한다.

\section{제24조의2(관광활동의 차별금지)}

(2) 국가와 지방자치단체 및 관광사업자는 장애인이 관광활동에 참여할 수 있도록 정당한 편의를 제공하여야 한다.

(3) 국가와 지방자치단체는 장애인이 관광활동에 적극적으로 참여할 수 있도록 필요한 시책을 강구 하여야 한다. 
「장애인차별금지법 시행령」 중 문화예술사업자의 적용 범위에「박물관 및 미술관 진흥법」 제2조에 따른 국공립 박물관·미술관, 국공립·사립대학 박물관·미술관, 전 시실 바닥면적 $500 \mathrm{~m}^{2}$ 이상의 사립 박물관·미술관을 명시하고 있다.

장애인의 이동 편의와 물리적 접근성은 다양한 활동의 기본 요건으로, 박물관·미 술관 방문을 포함한 문화예술 활동에도 마찬가지로 적용된다. 이에 관련한 법제도 및 정책 등을 살펴볼 필요가 있다.

가장 대표적으로 「장애인·노인·임산부 등의 편의증진보장에 관한 법률」은 장애 인 이동 편의에 대한 법적 근거이다. 제8조(편의시설 설치 기준) 2 항에 따르면 “편 의시설의 구조와 재질 등에 관한 세부기준은 보건복지부령으로 정한다. 이 경우 편 의시설의 종류별 안내 내용과 안내 표시 디자인 기준을 함께 정하여야 한다. 〈개정 2019.1.15.〉”고 명시되어있다. 동법 제 10 조 2 〈장애물 없는 생활환경 인증 제도〉 를 운영하고 있다. 동법의 시행령 제3조에 편의시설 설치 대상시설을 구분하고 있 는데, 이중 박물관은 문화 및 집회 시설로서 인증 의무시설로 지정되어 있다.

편의시설 설치에 대한 법령 외에도「교통약자이동편의 증진법」은 교통약자가 안 전하고 편리하게 이동할 수 있도록 교통수단, 여객시설 및 도로에 이동편의시설을 확충하고 보행환경을 개선하는 항목들을 명시하고 있으며, 동법 제3조는 "교통약자 는 인간으로서의 존엄과 가치 및 행복을 추구할 권리를 보장받기 위하여 교통약자 가 아닌 사람들이 이용하는 모든 교통수단, 여객시설 및 도로를 차별 없이 안전하고 편리하게 이용하여 이동할 수 있는 권리”로서 이동권을 명시하고 있다.

그 외 발달장애인 권리 보장 및 지원에 관한 법률」 제 27 조는 문화예술여가체육 활동 등 지원 "국가와 지방자치단체는 발달장애인이 영화, 전시관, 박물관 및 국가. 지방자치단체 등이 개최하는 각종 행사 등을 관람·참여·향유할 수 있도록 발달장애 인을 지원할 수 있다.”고 명시하고 있다.

고령화로 인하여 장애가 발생할 수 있다는 점을 고려했을 때, 「저출산 고령사회 기본법」을 살펴보면, 제 14 조에 여가·문화 및 사회 활동의 장려의 일환으로 국가 및 지방자치단체의 의무로 '노후의 여가와 문화활동 장려 및 이를 위한 기반 조성', 및 '여가 등 각 분야에서 적절한 상담과 교육을 받을 수 있도록 필요한 시책 강구' 등의 내용을 담고 있음을 알 수 있다. 이처럼 장애인과 관련한 법령 내에 문화 향유에 대한 참여에 대한 지원, 관련한 정당한 편의 제공의 내용이 명시되어있어, 장애인의 
문화활동 및 문화향유 활동에 대한 법적 근거를 확인할 수 있다.

문화분야 법제도 내에서는 문화권을 명시한 문화기본법 외에도, 문화산업진흥법, 문화예술진흥법, 문화예술교육지원법, 문화다양성의 보호와 증진에 관한 법률에 장 애인이 문화예술활동을 차별 없이 할 수 있도록 편의를 제공해야 한다고 명시하고 있다.

\section{2. 장애인의 박물관·미술관 접근성 관련 제도 및 정책}

\section{가. 장애물 없는 생활환경 인증제도}

〈장애물 없는 생활환경 인증제도〉는 2008년부터 시행되고 있으며 「장애인·노 인·임산부 등의 편의증진 보장에 관한 법률」 제 10 조의 2 제 3 항에 해당하는 건축물 은 의무적으로 인증받도록 하고 있다. 박물관·미술관 장애인 접근성과 관련하여 법 에 근거하여 적용되고 있는 대표적인 제도이다.

2009년 이후 설치된 문화·예술·체육시설 중 본 인증 120 개, 예비인증 225 개로 (2020.04 기준) 이 중 박물관·미술관·전시관 관련한 본 인증 20개 시설(16\%)(국립 6개, 공립 14 개), 예비인증 38개 시설(17.3\%)이다. 15$)$

- (박물관·미술관·전시관) 예비인증 $\rightarrow$ 본 인증( $\bigcirc)$ : 17 개, 이중 국립기관 5 개(국 립현대미술관서울관, 국립부산과학관, 국립한글박물관, 국립 6.25전쟁납북자 기념관, 국립충주기상과학관)

- (박물관·미술관·전시관) 예비인증 $\rightarrow$ 본 인증(x): 9개, 이중 국립 기관 1 개(국립 미술품수장보존센터)

- (박물관·미술관·전시관) 예비인증 상태(준공 중): 30 개 이중 국립 기관 5 개(국 립춘천박물관 복합문화관, 국립항공박물관, 국립민속박물관 개방형 수장고, 국 립세계문자박물관, 국립광주과학관 어린이 과학체험관)

15) BF 인증 내용의 경우, 한국장애인개발원 홈페이지에 자세히 기술되어있음: 예비인증과 본인증의 경우 인 증 종류와 신청 시기에 따라 구분됨. 즉, 예비인증의 경우 개별시설 또는 지역의 설계에 반영된 내용을 대상으로 본인증 신청 전의 상태에 받는 인증을 의미함. 본 인증의 경우 개별시설의 공사를 완료한 후를 의미함 참고: 한국장애인개발원 홈페이지 https://www.koddi.or.kr/bf/info/bf.do(2020.09 접속기준) 
한편, 장애인등편의법에 따르면 ' 15 년 이전 건립된 국·공립 박물관·미술관은 「장 애물 없는 생활환경 인증」 의무가 부여되지 않아, 실질적으로 대다수 박물관.미술 관은 미인증기관인 실정이다.

장애인 시설 기준과 관련하여 〈장애물 없는 생활환경 인증제도〉외에 공공디자인 차원의16) 유니버설디자인 관련하여 자치단체별로 조례를 통하여 적용하고 있음을 알 수 있다. 조례에서 정의하는 '유니버설디자인'이란 성별, 연령, 국적 및 장애의 유무와 관계없이 모든 시민이 안전하고 편리하게 이용할 수 있는 환경을 설계하는 것(서울특별시 유니버설디자인 도시 조성 기본 조례 기준)으로 명시하고 있다. 2020 년 8월 기준 총 25 개의 관련 조례가 제정되어있다. 자치단체의 조례별로 조항 의 차이가 있으나, 가이드라인 수립의 의무를 명시한(경상남도 유니버설디자인 조 례) 경우, 다음의 각호에 대한 고려를 명시하고 있다.

- 장애인·노인·임산부 등의 편의 증진 보장에 관한 사항

- 교통약자의 이동 편의 증진에 관한 사항

- 보행 안전 및 편의 증진에 관한 사항

- 다중이용 및 공공시설의 안전관리에 관한 사항

- 건축물·가로시설물·공원 등 공적인 도시환경에 관한 사항

\section{나. 웹 접근성 인증제도}

웹 접근성(web accessibility)은 장애인이나 고령자분들이 웹 사이트에서 제공 하는 정보를 비장애인과 동등하게 접근하고 이용할 수 있도록 보장하는 것으로 「국 가정보화기본법」과「장애인차별금지 및 권리구제 등에 관한 법률(이하 “장애인차별 금지법”)」등 법률에 명시된 의무사항이다. 이에 따라 모든 공공기관은 2009년 4월 11일부터 웹 접근성을 준수해야 하고, 단계적으로 2015년까지 모든 웹 사이트가 웹 접근성을 준수하도록 하였다.

16)「공공디자인의 진흥에 관한 법률」 제 10 조의 공공디자인 사업을 추진의 기본원칙에서 "연령, 성별, 장애 여부, 국적 등에 관계없이 모든 사람들이 안전하고 쾌적하게 환경을 이용할 수 있는 디자인을 지향한다." 라고 명시되어있다. 이는 유니버설디자인이라는 단어를 사용하고 있지는 않지만, 자치단체의 유니버설디 자인 조례에서 정의하고 있는 내용과 일치함을 알 수 있다. 
「국가정보화기본법」제32조(장애인·고령자 등의 정보접근 및 이용 보장 )

(1) 국가기관 등은 인터넷을 통하여 정보나 서비스를 제공할 때 장애인·고령자 등이 쉽게 웹 사이트를 이용할 수 있도록 접근성을 보장하여야 한다.

(사)한국장애인단체총연합회 한국웹접근성인증평가원에서는 「국가정보화기본법」 제32조의2제4항에 따라 장애인 및 고령자가 웹 사이트 이용에 불편이 없도록 웹 접 근성 표준을 준수한 우수 사이트에 대해 심사후 품질인증 마크를 부여하고 있다.17) 2020년 9월 접속기준으로 홈페이지 내 박물관·미술관 인증(유효) 기관은 박물관 2곳(서울역사박물관, 국립민속박물관) 미술관 4곳(호암미술관, 경남도립미술관, 국 립현대미술관, 리움)으로 매우 미비한 상황임을 알 수 있다.

\section{다. 박물관 및 미술관 진흥법 관련 장애인 접근성 관련 제도}

박물관 및 미술관 진흥법에 따르면, 공립박물관·미술관의 경우 관람료에 대하여 해당 지자체의 조례에 따르게 되어 있다. 지자체별 조례로 지정한 박물관·미술관 운영 규칙 등에 따르면 장애인을 유료 면제 대상으로 지정하고 있음을 알 수 있다. 국립 박물관 및 미술관의 경우 〈국립박물관 전시품 관람규칙〉 및 〈국립현대미술관 전시품 관람규칙> 제5조 6항에「장애인복지법」제32조에 따라 등록된 장애인 및 그와 동행하는 보호자에 관람료 면제의 대상 명시하고 있다.

또한, 박물관 및 미술관 진흥법 제 26 조 및 동법 시행령 제 17 조의 2 에 따르면 박 물관 및 미술관의 평가 시행을 명시하고 있다. 이는 박물관.미술관 운영의 질적 수 준 향상을 위하여 등록 3년이 경과한 국·공립 박물관 및 미술관을 대상으로 평가를 시행하고 우수 기관을 인정하는 제도이다. 평가 항목 중 박물관.미술관의 교육대상 다양화 노력(공립미술관), 문화향유 기회 확대(국립박물관)의 경우 박물관·미술관에 서의 장애인을 포함한 다양한 계층의 접근은 높이기 위한 노력을 평가하고 있다.

17) 한국웹접근성인증평가원 홈페이지 내용 발췌(http://www.wa.or.kr/m1/sub1.asp)(2020.09. 접속기준) 


\section{라. 관련 계획}

1) 제5차 장애인 정책 종합계획(2018 2022)

2018년 발표된 5차 계획(2018 2022) 내에 장애인들의 문화·체육·관광과 관련 하여 문화예술·관광 분야 4 개 과제, 체육 분야 3 개 등 총 7 개의 세부추진과제를 제 시하고 있다. 이중 장애인의 문화·예술 향수 기회 확대, 장애인 관광·여가 향수권 증진 등이 박물관·미술관에서의 장애인 접근성과 관련한 사업 추진 가능 영역으로 볼 수 있다.

무장애 환경 관련 분야에서, 정보 접근성 보장, 편의 증진·의사소통 지원 강화 영역 관련하여 박물관·미술관 환경에서의 접근성을 포괄할 수 있다.

〈표 2-4〉 제5차 장애인정책 종합계획(2018 2022) 내 박물관-미술관 장애인 접근성 관련 항목

\begin{tabular}{|c|c|}
\hline 세부 추진과제 & 세부 계획 \\
\hline $\begin{array}{l}\text { 장애인의 문화·예술 향수 } \\
\text { 기회 확대 }\end{array}$ & $\begin{array}{l}\text { 통합문화이용권 지원금액 현실화 } \\
\text { 발달장애인(만 } 9 \text { 9ㅅ 24세)을 위한 찾아가는 장애인 문화예술학교 지원 }\end{array}$ \\
\hline 장애인 관광·여가 향수권 증진 & $\begin{array}{l}\text { 열린 관광지 조성 확대('22년까지 100개소) } \\
\text { 특수학교청소년 체험여행 지원(연간 500명) }\end{array}$ \\
\hline $\begin{array}{c}\text { 웹·모바일 } \\
\text { 정보접근성 보장 }\end{array}$ & $\begin{array}{l}\text { 웹·모바일 앱 등 정보접근성 보장 강화 } \\
\text { 장애인을위한 정보통신 보조기기 개발·보급 }\end{array}$ \\
\hline $\begin{array}{c}\text { 장애물 없는 생활환경(BF) } \\
\text { 인증 활성화 }\end{array}$ & $\begin{array}{l}\text { 일정규모이상 민간 건축물의 } \mathrm{BF} \text { 인증 의무화 단계적 확대 } \\
\text { 및 인증 유도를 위한 실효성 있는 인센티브 제공 방안 마련 } \\
\text { 장애인편의증진 강화를 위해 BF 인증심사 제도 개선 }\end{array}$ \\
\hline 유니버설디자인 환경 조성 & $\begin{array}{l}\text { 유니버설디자인환경 조성 시범사업 추진(‘20 21) } \\
\text { 장애인주거 환경 개선 추진 } \\
\text { 장애인문화시설 이용 등을 위한 유니버설디자인 매뉴얼 개발·보급 }\end{array}$ \\
\hline
\end{tabular}

자료:〈제5차 장애인정책 종합계획〉(2018 2022)에 근거하여 작성

\section{2) 제4차 편의증진 국가종합 5개년 계획(2015 2019)}

「장애인·노인·임산부 등의 편의증진 보장에 관한 법률」 제 12 조에 따라 계획된 2014년 제4차 편의증진 국가종합 5개년 계획(2015 2019) 내에서 박물관·미술관 장애인 접근성 관련하여, 장애인 없는 생활환경 인증 확대, 문화시설의 편의증진 세 부 과제 등을 살펴볼 수 있다. 장애물 없는 생활환경 인증확대 세부 계획은 민간시 설 $\mathrm{BF}$ 인증 자발적 참여 확대를 목표로 하고 있는데, 사립 박물관·미술관의 경우(바 
닥면적 500 제곱미터 이상) $\mathrm{BF}$ 인증의 의무 대상이지만, 관련한 제도 적용이 활발 하지 않은 상황에서 이와 같은 편의증진 세부 계획에서의 참여 독려가 적용될 수 있다. 또한 문화시설의 편의증진은 장애인의 감각적 접근성 개선을 위한 노력의 일 환으로 박물관·미술관에서 제공하는 다양한 정보와 서비스에 대한 접근을 높일 수 있는 기반을 마련할 수 있는 제도적 장치로 볼 수 있다.

〈표 2-5〉 편의증진 국가종합 계획 세부 계획 중 박물관·미술관 접근성 관련 항목

\begin{tabular}{|c|c|c|}
\hline 추진과제 & 세부계획 & 목표 \\
\hline $\begin{array}{l}\text { 장애물 없는 } \\
\text { 생활환경 } \\
\text { 인증 확대 }\end{array}$ & $\begin{array}{l}\text { 공공 및 민간시설 } \\
\text { 이용편의 수준 향상 }\end{array}$ & $\begin{array}{l}\text { 국가-지자체가 신축하는 건축물의 BF 인증 의무 취득 } \\
\text { (연평균 } 1,184 \text { 건) } \\
\text { 민간시설BF 인증 자발적 참여 확대: } 92 \text { 건('14) } \rightarrow 200 \text { 건('19) }\end{array}$ \\
\hline $\begin{array}{l}\text { 문화시설의 } \\
\text { 편의증진 }\end{array}$ & $\begin{array}{c}\text { 점자도서, 녹음서 등 } \\
\text { 대체자료 제작·보급 } \\
\text { 높낮이조절책상 등 } \\
\text { 공공도서관 독서보조기기 } \\
\text { 지원 문화 접근권 강화 }\end{array}$ & $\begin{array}{l}\text { 점자도서, 점자악보 등 지원: 23,750종, 107억원(“15 ‘19) } \\
\text { 독서보조기기지원: 105개소, 10억(“15 “19) } \\
\text { 상영관실태조사 등 용역사업 추진("15 "19) } \\
\text { 한글자막 및 화면해설영화 제작지원 } \\
\text { 사립문화시설의 장애인편의시설 개선 지원 } \\
\text { 열린관광지공모 사업 }\end{array}$ \\
\hline
\end{tabular}

자료: 보건복지부(2014), 〈제4차 편의증진 국가종합 5개년 계획(2015 2019)〉을 토대로 작성

\section{3) 박물관·미술관 진흥 중장기 계획(2019 2023)}

「박물관 및 미술관 진흥법」 제9조에 따라 2019년 문화체육관광부에서 발표한 박 물관·미술관 진흥 중장기 계획 내에 장애인 접근성 관련하여, 박물관·미술관의 장 애물 없는 생활환경 인증」취득 촉진, 박물관·미술관 장애인이용 실태조사 및 가이드 라인 제시, 모두를 위한 박물관·미술관 프로그램 확대 등의 사업이 제시되고 있다.

〈표 2-6〉 박물관-미술관 진흥 중장기 계획 내 장애인 접근성 관련 항목

\begin{tabular}{|c|c|}
\hline 추진과제 & 세부계획 \\
\hline $\begin{array}{l}\text { 박물관·미술관의「장애물 없는 } \\
\text { 생활환경 인증」취득 촉진 }\end{array}$ & $\begin{array}{l}\text { 박물관·미술관 평가인증지표에 ‘장애물 없는 생활환경 인증' 여부를 포함하 } \\
\text { 여, 인증 촉진 } \\
\text { 공립 박물관·미술관의 ‘장애물 없는 환경' 조성을 위한 시설 개선 지원 }\end{array}$ \\
\hline $\begin{array}{l}\text { 박물관·미술관 장애인이용 } \\
\text { 실태조사 및 가이드라인 제시 }\end{array}$ & $\begin{array}{l}\text { 박물관·미술관의 장애인 이용에 관한 전반적인 실태조사 } \\
\text { 장애인 접근성 강화를 위한 박물관·미술관 가이드라인 제시 }\end{array}$ \\
\hline $\begin{array}{c}\text { 모두를 위한 박물관·미술관 } \\
\text { 프로그램 확대 }\end{array}$ & 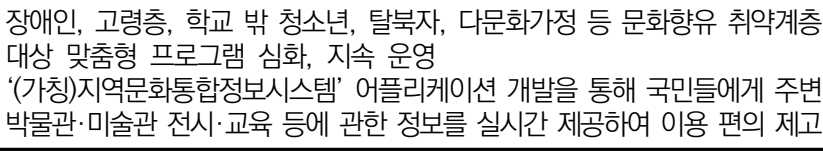 \\
\hline
\end{tabular}

자료: 문화체육관광부(2019), 〈박물관-미술관 진흥 중장기 계획〉을 토대로 작성 


\section{4) 관광관련 계획}

관광정책 내에서 무장애관광 관련 계획 관련하여, 제5차 관광진흥 5개년계획 (2018 2022), 제3차 관광개발 기본계획(2012 2021), 제6차 권역별 관광개발계 획(2017 2021) 등을 통하여 관광지에서의 장애인 접근성 향상을 위한 물리적 환 경 개선(유니버설디자인 적용), 관광상품 및 정보서비스 기회 확대 등 이 박물관·미 술관의 접근성 개선과 관련한 사업으로 살펴볼 수 있다.

〈표 2-7〉 관광관련 국가종합 계획 세부 계획 중 박물관-미술관 접근성 관련 항목

\begin{tabular}{|c|c|c|}
\hline 추진과제 & 세부계획 & 관련계획 \\
\hline $\begin{array}{l}\text { 취약계층 관광 } \\
\text { 유니버설디자인 } \\
\text { 도입 확대 }\end{array}$ & $\begin{array}{l}\text { 고령자 및 장애인 등 취약계층의 여행 환경 개선을 위한 유니 } \\
\text { 버설디자인 도입 확대 } \\
\text { 취약계층맞춤형 관광 정보 제공(교통, 숙박시설 등), 취약계층 } \\
\text { 관광 불편요소에 대한 의견 수렴 및 개선 }\end{array}$ & $\begin{array}{l}\text { 제5차 관광진흥 } \\
\text { 5개년 계획 } \\
\text { (2018 2022) }\end{array}$ \\
\hline $\begin{array}{l}\text { 장애인 관광 } \\
\text { 여건 개선 }\end{array}$ & $\begin{array}{l}\text { 관광시설의 무장애화 추진 } \\
\text { 장애인 시설 설치를 위한 제도 마련 } \\
\text { 장애인 관광 편의시설 확충 및 인력 양성 }\end{array}$ & $\begin{array}{c}\text { 제3차 } \\
\text { 관광개발기본계획 }\end{array}$ \\
\hline $\begin{array}{c}\text { 장애인/복지관광 } \\
\text { 활성화 }\end{array}$ & $\begin{array}{l}\text { 장애인 관광을 위한 사회적 인식을 개선하여 장애인의 관광 기 } \\
\text { 회 확대 } \\
\text { 장애인/노약자를 위한 전용 교통수단을 확대하고 이를 시행하 } \\
\text { 는 기업에 인센티브 제공 } \\
\text { 장애인들을 위한 기초인프라 확대로 관광활동을 즐길 수 있는 } \\
\text { 기반 조성 }\end{array}$ & $\begin{array}{c}\text { 제6차 권역별 관광개발 } \\
\text { 계획(서울시) }\end{array}$ \\
\hline $\begin{array}{l}\text { 유나버설 디자인 } \\
\text { 적용 관광지 } \\
\text { 환경 개선 }\end{array}$ & $\begin{array}{l}\text { 유니버설디자인을적용한 이지플레이스 구축(광주권) } \\
\text { 노인, 장애인을 위한여행 촉진 사업(광주권) } \\
\text { 장애인안내판 설치 가이드라인(대전권) } \\
\text { 사회적약자 관광편의시설 개선(전북권) }\end{array}$ & $\begin{array}{c}\text { 제6차 권역별 관광개발 } \\
\text { 계획(지역별) }\end{array}$ \\
\hline
\end{tabular}

자료: 문화체육관광부(2019), 「무장애 관광환경 조성 계획 수립 연구」 내용을 토대로 연구자 재작성 
〈표 2-8〉 장애인 접근성 유형별 법제도 및 정책 현황

\begin{tabular}{|c|c|c|c|}
\hline 대분류 & 법률 & $\begin{array}{c}\text { 세부 접근성 } \\
\text { 요소 }\end{array}$ & 제도 및 정책 현황 \\
\hline \multirow[t]{3}{*}{$\begin{array}{l}\text { 물리적 } \\
\text { 접근성 }\end{array}$} & \multirow{3}{*}{$\begin{array}{l}\text { - 교통약자이동편 } \\
\text { 의 증진법 } \\
\text { - 장애인·노인·임 } \\
\text { 산부등의 편의증 } \\
\text { 진보장에 관한 법 } \\
\text { 률 } \\
\text { - 국가정보화기본 } \\
\text { 법」제32조의2제 } \\
\text { 4항 }\end{array}$} & $\begin{array}{l}\text { 이동 } \\
\text { 편의성/물리적 } \\
\text { 환경 조성 }\end{array}$ & $\begin{array}{l}\text { - 편의증진 국가종합계획: 장애물 없는 생활환경 인증 } \\
\text { 확대 } \\
\text { - 제 } 5 \text { 차 관광진흥 } 5 \text { 개년 계획: 취약계층 관광 유니버설 } \\
\text { 디자인 도입 확대 } \\
\text { - 제 } 3 \text { 차 관광개발기본계획: 관광시설의 무장애화 추진 } \\
\text { - 박물관·미술관 진흥 중장기 계획: 박물관·미술관의 } \\
\text { 「장애물 없는 생활환경 인증」취득 촉진 } \\
\text { - 장애물 없는 생활환경 인증제도 적용: 국공립, 대학, } \\
\text { 사립 박물관·미술관 }\end{array}$ \\
\hline & & 감각적 접근성 & $\begin{array}{l}\text { - 편의증진 국가종합 계획: 점자도서, 녹음서 등 대체자 } \\
\text { 료 제작·보급 } \\
\text { - 제6차 권역별 관광개발 계획(지역별): 장애인안내판 } \\
\text { 설치 가이드라인(대전권) } \\
\text { - 제5차 장애인정책 종합계획: 장애인을위한 정보통신 } \\
\quad \text { 보조기기 개발·보급 }\end{array}$ \\
\hline & & 웹 접근성 & - 웹접근성 인증제도: 품질인증 마크 부여 \\
\hline \multirow{3}{*}{$\begin{array}{l}\text { 서비스 } \\
\text { 접근성 }\end{array}$} & \multirow{8}{*}{$\begin{array}{l}\text { - 장애인복지법 } \\
\text { - 장애인차별금지 } \\
\text { 및 권리구제 등에 } \\
\text { 관한 법률 } \\
\text { - 발달장애인 권리 } \\
\text { 보장 및 지원에 } \\
\text { 관한 법률 } \\
\text { - 저출산 고령사회 } \\
\text { 기본법 } \\
\text { - 문화기본법 } \\
\text { - 문화산업진흥법 } \\
\text { - 문화예술진흡법 } \\
\text { - 문화예술교육 } \\
\text { 지원법 } \\
\text { - 문화다양성의 } \\
\text { 보호와 증진에 } \\
\text { 관한 법률 } \\
\text { - 관광진흥법 }\end{array}$} & 태도적 접근성 & $\begin{array}{l}\text { - 제6차 권역별 관광개발 계회(서울시): 장애인/노약자 } \\
\text { 를 위한 전용 교통수단을 확대하고 이를 시행하는 기 } \\
\text { 업에 인센티브 제공 } \\
\text { - 박물관·미술관 진흥 중장기 계획: 박물관·미술관 가이 } \\
\text { 드라인 제시 }\end{array}$ \\
\hline & & 경제적 접근성 & $\begin{array}{l}\text { - 각 지자체별 조례로 지정한 박물관·미술관 운영 규칙: } \\
\text { 장애인 유료 면제 대상 } \\
\text { - 제5차 장애인정책 종합계획: 통합문화이용권 지원금액 } \\
\text { 현실화 }\end{array}$ \\
\hline & & 웹 접근성 & $\begin{array}{l}\text { - 박물관·미술관 진흥 중장기 계획: ‘(가칭)지역문화통합 } \\
\text { 정보시스템'어플리케이션 개발 } \\
\text { - 제5차 장애인정책 종합계획: 웹. 모바일 정보접근성 보장 }\end{array}$ \\
\hline \multirow[t]{3}{*}{$\begin{array}{l}\text { 프로그램 } \\
\text { 접근성 }\end{array}$} & & 지적 접근성 & $\begin{array}{l}\text { - 박물관-미술관 진흥 중장기 계획:(장애인) 대상 맞춤형 } \\
\text { 프로그램 심화 } \\
\text { - 박물관 및 미술관의 평가제도: 다양한 계층 교육 프로 } \\
\text { 그램 접근 } \\
\text { - 제5차장애인정책종합계획: 발달장애인(만9세 24세)을 } \\
\text { 위한 찾아가는 장애인 문화예술학교 지원 }\end{array}$ \\
\hline & & 정서적 접근성 & - \\
\hline & & $\begin{array}{l}\text { 의사결정에 } \\
\text { 대한 접근 }\end{array}$ & - \\
\hline \multirow{2}{*}{$\begin{array}{l}\text { 문화적 } \\
\text { 접근성 }\end{array}$} & & 정서적 접근성 & $\begin{array}{l}\text { - 제6차 권역별 관광개발 계획(서울시): 장애인 관광을 위 } \\
\text { 한 사회적 인식을 개선하여 장애인의 관광 기회 확대 }\end{array}$ \\
\hline & & $\begin{array}{l}\text { 의사결정에 } \\
\text { 대한 접근 }\end{array}$ & - \\
\hline
\end{tabular}


장애인 접근성 강화를 위한 박물관.미술관 가이드라인 수립 방향 연구

제3장 박물관- 미술관

장애인 가이드라인

사례 분석 



\section{제1절 박물관·미술관 장애인 가이드라인 선행연구}

\section{1. 해외 박물관·미술관 장애인 가이드라인의 발전과 유형}

$\mathrm{UN}$ 의 장애인 인권선언〉을 비롯한 장애인 관련 법제도를 근간으로하여 국외의 경우 1990년대 이후로 꾸준히 그 유형과 범주를 확장하면서 발간되고 있다. 박물 관·미술관 공간의 특수성에 기인한 시설물 설치와 그에 따라 발생되는 서비스 등에 대한 접근을 다루기 때문에 개별 박물관 차원보다는 박물관연합체 또는 국가단위에 서 장애인 문화접근성 해소 차원에서 발간되고 있다.

박물관·미술관 장애인 가이드라인의 경우, 규격화된 가이드라인이 정해져 있다고 보기 어렵고, 가이드라인의 '목적'에 따라 그 내용과 접근 방법이 상이하게 나타나 고 있다. 우선 내용적인 범위로 본다면, 장애인의 '전시'에 대한 디자인과 설치를 중심으로 다루는 것과 좀 더 종합적인 차원의 서비스 영역을 포괄하는 유형으로 구 분된다.

우선〈Smithsonian Guidelines for Accessible Exhibition Design〉(1996) 은 대표적인 전시 디자인 실무 지침서 성격의 가이드라인이다. 부분적으로 1968년 건축 장벽 법, 1973 년 재활법 및 1990년 ADA에 대해 수립된 건축 표준을 기반으 로 하되 다양한 박물관연합체인 스미소니언박물관의 전시 노하우와 전문인력의 아 이디어를 근거로 '전시 디자인'에 초점을 두고 구성되었다. 현장에서 실행 가능한 실무 지침서의 성격이 강하며. 물리적 접근성에 대한 세부 지침이 매우 상세하게 기술되어있는 장애인 관련 시설 지침의 성격을 띤다.

프랑스 문화부가 2016년 발간한 〈Exposition et parcours de visite accessibles〉의 경우 스미소니언 가이드라인과 마찬가지로 전시 디자인의 실질적 요소들 에 대한 전문적 지침서로 볼 수 있다. 스미소니언 가이드라인이 1996년 이후 업데 이트가 되고 있지 않은 상황에서 프랑스 문화부의 가이드라인의 경우 최신의 전시 
경향성을 반영하고, 사용자 이용환경에 맞춘 설치 지침을 매우 상세하게 담고 있다. 특히 유니버설디자인에 기초하여 '개별 관람 주체'로서 장애인의 접근성의 장벽 을 세분화하고 이를 인체공학적으로 해결할 방안을 표준화된 수치로 제시하고 있다 는 점이 큰 장점으로 볼 수 있다. 또한, 유니버설디자인에 기초하여 서비스 디자인 을 고려한 설치 기준을 제시한다는 점에 선 사례보다 발전된 형태의 가이드라인으 로 볼 수 있다.

이와는 달리 '서비스 가이드라인' 은 앞서 살펴본 설치 중심의 지침서와는 달리, 박물관·미술관 전반의 운영에 대한 접근을 전제로 종합적인 성격을 띤다. 이러한 유형의 가이드라인의 경우 ‘물리적 접근성' 외에도 장애인에게 발생할 수 있는 다양 한 접근성의 장벽을 먼저 살펴보고, 이를 해소할 방안을 제시한다. 대표적인 사례로 영국 The Council for Museums, Archives and Libraries에서 1997년 발간한 〈resource: Disabtility Directory for Museums and Galleries〉를 들 수 있다.

본 지침은 장애인 접근성에 대한 개념과 기본 원칙을 기술하고, 박물관.미술관 운 영 전반에 필요한 서비스와 시설 설치요건을 종합적으로 다룬 가이드라인으로 볼 수 있다. 영국 박물관·미술관을 관장하는 기구로서 The Council for Museums, Archives and Libraries은 본 가이드라인을 시작으로, 영국의 박물관.미술관에서 의 장애인 서비스에 대한 여건을 위한 마련을 위하여 〈박물관·미술관 장애인 접근성 점검 지표 개발〉, 〈일반인을 위한 장애인 접근성 실무 가이드 시리즈>(총 12 개 시리 즈) 마련하였다. 이는 장애인 가이드라인이 박물관 '내부'의 전문 영역에서 머무는 것이 아닌 인식 개선 및 확산의 역할까지 수행하는데 정책적인 차원에서 큰 의미가 있다고 볼 수 있다.

방법론적으로 시설 지침의 경우는 상위 법 제도의 기준에 부합하도록 기술되지 만, 특수 전문공간인 박물관-미술관에서 장애인에 발생할 수 있는 모든 경우에 수를 전제로 해야 하므로 오랜 기간 축적된 실무자들의 노하우를 반영하여 기술된다. 최 근에는 유니버설디자인의 차원에서 장애인의 인체공학적인 부분을 최대한 고려하 여, 실무자들의 노하우를 보완하고 이를 표준화하기 위하여 노력하고 있는데, 프랑 스 문화부 가이드라인이 대표적이라 할 수 있다.

서비스 가이드라인의 경우, 장애인 문화접근에 대한 정책 모델을 설계를 위한 유 형과 실 수용자인 장애인이 요구를 반영하여 현장 서비스의 가이드라인을 설계하는 
유형으로 구분된다..

국가 단위 또는 국가 연합(EU) 차원의 장애인 접근성에 대한 계획 수립을 목적으 로 하는 경우, 정책과 현황에 대한 분석을 기초로 서비스를 설계하는데 $\mathrm{EU}(2017)$ 의 〈Report on the accessibility in Central Europe〉와 영국 DCMS(2008)의 〈Secretary of State Report on Disability Equality Department for Culture, Media and Sport>가 대표적이다.

이와는 반대로, 실 수용자인 장애인과 그들의 동반자, 장애인 복지영역의 전문가 와 실무자의 요구를 반영하여 현재의 문제점 개선방안 마련을 목적으로 대표적 사 례로는 호주 Australian Museum/National Museum of Australia(2005), 「Many voices making choices: Museum audiences with disabilities」와 영국의 장애 인 단체인 Vocaleyes에서 발간하고 있는 〈Museum access information Guidelines>(Vocaleyes, 2016; 2018)가 있다.

〈표 3-1〉 본 연구에서 검토한 국외 장애인 관련 박물관·미술관 가이드라인

\begin{tabular}{|c|c|c|c|}
\hline 국가 & 연도 & 발행처 & 제목 \\
\hline \multirow[t]{2}{*}{ EU } & 2012 & EU & $\begin{array}{l}\text { Report policies and good practice in the } \\
\text { public arts and in cultural institutioins to } \\
\text { promote better access to and wider } \\
\text { participation in culture }\end{array}$ \\
\hline & 2017 & Interreg Central Europe & $\begin{array}{c}\text { Report on the accessibility in central } \\
\text { europe }\end{array}$ \\
\hline UN & 2003 & UN & $\begin{array}{l}\text { Accessibility for the Disabled - A Design } \\
\text { Manual for a Barrier Free Environment }\end{array}$ \\
\hline UNESCO & 1981 & ICOM & Museums and disabled persons \\
\hline 대만 & 2018 & $\begin{array}{l}\text { British Council/Taiwan } \\
\text { Access for All } \\
\text { Association }\end{array}$ & $\begin{array}{c}\text { Art for Social Impact: Aging \& Disability } \\
\text { Research in Taiwan }\end{array}$ \\
\hline \multirow{2}{*}{ 독일 } & 2011 & $\begin{array}{c}\text { Deutscher Blinden-und } \\
\text { Sehbehindertenverband } \\
\text { e.V. }\end{array}$ & $\begin{array}{l}\text { Guidelines to ensure accessibility to } \\
\text { museums and exhibitions for the blind and } \\
\text { partially sighted }\end{array}$ \\
\hline & 2013 & $\begin{array}{l}\text { Deutscher } \\
\text { Museumsbund }\end{array}$ & $\begin{array}{l}\text { Das inklusive Museum - Ein Leitfaden zu } \\
\text { Barrierefreiheit und Inklusion }\end{array}$ \\
\hline \multirow{2}{*}{ 미국 } & 1994 & $\begin{array}{l}\text { National Assembly of } \\
\text { State Arts Agencies }\end{array}$ & $\begin{array}{l}\text { Design for Accessibility: A Cultural } \\
\text { Administrator's Handbook }\end{array}$ \\
\hline & 1996 & $\begin{array}{l}\text { Smithsonian Accessibility } \\
\text { Program }\end{array}$ & $\begin{array}{l}\text { Smithsonian Guidelines for Accessible } \\
\text { Exhibition Design }\end{array}$ \\
\hline
\end{tabular}




\begin{tabular}{|c|c|c|c|}
\hline 국가 & 연도 & 발행처 & 제목 \\
\hline & 2016 & University of Michigan & $\begin{array}{l}\text { Welcoming All Visitors: Museums, } \\
\text { Accessibility, and Visitors with Disabilities }\end{array}$ \\
\hline 벨기에 & & Atout Culture & $\begin{array}{l}\text { Musées et handicap Guide pratique de } \\
\text { l'accessibilité }\end{array}$ \\
\hline 스웨덴 & & $\begin{array}{c}\text { Cultural Heritage Without } \\
\text { Borders }\end{array}$ & $\begin{array}{c}\text { Disability a toolkit for museums working } \\
\text { towards inclusion }\end{array}$ \\
\hline 스위스 & 2016 & $\begin{array}{l}\text { Association des musees } \\
\text { suisses }\end{array}$ & $\begin{array}{c}\text { Des musees accessibles a tous Information } \\
\text { et suggestion }\end{array}$ \\
\hline \multirow{14}{*}{ 영국 } & 2001 & $\begin{array}{c}\text { The Council for } \\
\text { Museums, Archives and } \\
\text { Libraries }\end{array}$ & $\begin{array}{c}\text { resource: Disabtility Directory for Museums } \\
\text { and Galleries }\end{array}$ \\
\hline & 2002 & $\begin{array}{l}\text { National Museums of } \\
\text { Scotland }\end{array}$ & Exhibitions for All \\
\hline & 2003 & $\begin{array}{l}\text { resource:The Council for } \\
\text { Museums, Archives and } \\
\text { Libraries }\end{array}$ & Disability Portfolio Guide 1 12 \\
\hline & 2007 & $V \& A$ & V\&A: Disability euqality scheme-actionplan \\
\hline & 2008 & $\begin{array}{l}\text { Research Centre for } \\
\text { Museums and Galleries } \\
\text { (RCMG) }\end{array}$ & $\begin{array}{l}\text { rethinking disability representation in } \\
\text { museums and galleries }\end{array}$ \\
\hline & 2008 & dcms & $\begin{array}{c}\text { Secretary of State Report on Disability } \\
\text { Equality Department for Culture, Media and } \\
\text { Sport }\end{array}$ \\
\hline & 2011 & University of Reading & $\begin{array}{l}\text { Guidelines for Including Volunteers with } \\
\text { Disabilities in Museum Work }\end{array}$ \\
\hline & 2015 & Arts Council of Wales & Equality Guide \\
\hline & 2016 & Voclaeyes & State of Museum Access 2016 \\
\hline & 2017 & ACE & Making a shift report \\
\hline & 2018 & Voclaeyes & State of Museum Access 2018 \\
\hline & 2019 & ACE & $\begin{array}{c}\text { Building Access: A good practice guide for } \\
\text { arts and cultural organisations }\end{array}$ \\
\hline & 2019 & MDNW & Age-Friendly-Museumschecklist \\
\hline & 2020 & $\begin{array}{l}\text { Research Centre for } \\
\text { Museums and } \\
\text { Galleries,University of } \\
\text { Leicester }\end{array}$ & $\begin{array}{c}\text { An ethical approach to interpreting disability } \\
\text { and difference }\end{array}$ \\
\hline \multirow[t]{2}{*}{ 프랑스 } & 2010 & $\begin{array}{l}\text { Ministère de la Culture et } \\
\text { de la Communication }\end{array}$ & $\begin{array}{c}\text { Etat des lieux de l'accessibilité des } \\
\text { étabilissements culturels aux personnes } \\
\text { handicapées mentales }\end{array}$ \\
\hline & 2016 & $\begin{array}{l}\text { Ministère de la Culture et } \\
\text { de la Communication }\end{array}$ & $\begin{array}{l}\text { Expositions et parcours de visite } \\
\text { accessibles }\end{array}$ \\
\hline
\end{tabular}




\begin{tabular}{c|c|c|c}
\hline 국가 & 연도 & 발행처 & 제목 \\
\hline \multirow{7}{*}{ 호주 } & 2002 & $\begin{array}{c}\text { Australian museum and } \\
\text { the national museum of } \\
\text { australia }\end{array}$ & $\begin{array}{c}\text { Energised, engaged, everywhere: older } \\
\text { australians \& museums }\end{array}$ \\
\cline { 2 - 5 } & 2005 & $\begin{array}{c}\text { Australian museum and } \\
\text { the national museum of } \\
\text { australia }\end{array}$ & $\begin{array}{c}\text { Many voices making choices: museum } \\
\text { audiences with disabilityes }\end{array}$ \\
\cline { 2 - 5 } & 2015 & Australian Museums & Disability Inclusion Action Plan \\
\cline { 2 - 5 } & 2017 & $\begin{array}{c}\text { Western Australian } \\
\text { Museum }\end{array}$ & 2018-2022 Disability Access \& Inclusion \\
Plan
\end{tabular}

\section{2. 국내 박물관·미술관 장애인 가이드라인 선행연구 검토}

국내에서는 공공부문에서 공식적으로 박물관·미술관 환경에서의 장애인 접근성 가이드라인이 발간된 것은 없다. 다만, 문화예술시설의 장애인 접근과 관련하여 일 부 사례 또는 분야로 박물관.미술관을 다루고 있는 사례를 찾아볼 수 있다. 이 역시 도 편의제공과 물리적 접근성을 중점적으로 다루고 있어, 앞서 살펴본 전반적인 장 애인 접근성에 대한 포괄적인 이해를 선행하고 있다고 보기 어렵다. 박물관·미술관 환경에서의 장애인 접근성을 다룬 국내 대표적인 선행 연구 보고서를 정리하면 다 음과 같다.

\section{가. 전병태(2010), 「공공 문화예술기관 장애인 서비스 개선방안」}

박물관·미술관을 포함한 공공 문화예술 기관의 장애인 서비스에 대한 현황 분석 및 개선방안을 제시한 연구보고서로써, 문화복지와 장애인 차별 금지법에 대한 이 해(문헌 조사), 편의시설 및 서비스 현황조사 및 분석(설문 및 현장조사), 장애인 서 비스 개선 정책방안(정책 제안)으로 구성되어있다.

현황 파악을 위하여 중앙 및 지방의 대표 문화시설 15 곳을 대상으로 설문과 현장 조사 하였으며, 「장애인 편의 증진법에」의해 규정된 문화예술시설에서의 장애인을 위한 편의시설과 포괄적 서비스를 조사하였다: 편의시설을 매개 시설, 내부시설, 위 생시설, 안내시설, 기타시설로 구분하였다.

조사대상(15개) 중 국립현대미술관(과천관), 국립중앙박물관, 국립부여박물관, 국립 
전주박물관, 국립경주박물관의 전시장 5 곳을 포함하고 있는데, 조사 당시 장애인에 게 정당한 편의(시설에 의한)가 이뤄지고 있지 않다고 평가되었다. 개선방안 중 문화 예술기관에서 장애인 대상 서비스를 제공하기 위한 개괄적인 가이드라인(general guidance) 방향을 권고사항으로 제시하고 있으며, 이는 장애인 접근성 제고, 시각/ 청각 장애인 서비스 제고/인터넷 정보제공 서비스 개선으로 구분하였다.

공공문화예술기관을 대상으로 문화시설에 특화된 서비스 평가표를 구성하여 현 황을 파악하고자 했다는 점에서 의의가 있다. 분야별 문화향유 특수성을 고려하지 않고 포괄적 편의 서비스에 대한 조사가 이뤄져 세부적인 개선방안은 제시하지 못 하고 있다.

\section{나. 국가인권위원회(2011)「장애인차별금지법상 인적 편의 제공18)에 관한 연구」}

문헌연구를 중심으로 인적 편의 제공과 관련한 국내·외 법령, 판례, 지침 및 기존 연구들을 고찰함으로써 장애인에 대한 정당한 편의 제공 및 인적 편의제공에 대한 기준을 도출하고자 하였다.

고용, 교육, 사법·행정 절차 및 서비스, 문화·예술·체육활동, 참정권 영역별로 「장애인차별금지법」이 요구하는 인적 편의의 내용 및 절차를 분석하고, 외국 사례 와 비교분석을 통하여 인적 편의가 효과적으로 제공되도록 하기 위한 정책제언 및 영역별로 인적 편의 제공 의무 기관이 준수해야 할 가이드라인을 제시하고 있다. 부분적으로 국·공립(대학) 박물관·미술관의 이용 시 필요한 인적 편의 제공으로, 관 람권(입장권) 예매·구매, 해설사 관람 코스 이용, 오디오가이드 서비스 이용, 소장품 정보에 대한 접근으로 구분하여 개괄적인 가이드라인(general guidance) 제안하 였다.

18) 본 연구에서는 "장애인이 장애가 없는 사람과 동등하게 같은 활동에 참여할 수 있도록" 해주는 목적을 달성하는데 일차적으로 기능하는 노동력으로, 편의 제공 의무자가 제공하는 것으로 정의 


\section{다. 문화체육관광부, 「유니버설디자인 실태분석 및 문화적 적용방안 연구」(2012)/ 「유니버설디자인 가이드라인 연구」(2013)}

문화체육관광부에서 2012/2013년 유니버설디자인 관련 실태분석 및 문화적 적 용(2012), 유니버설디자인 관련 가이드라인 연구(문화체육관광부, 2013)를 진행하 였다. 2012년 연구에서 사례 조사와 해외 각국의 정책을 소개하여 유니버설디자인 적용의 당위성을 보여주고 있다. 박물관·미술관 분야로는 국립중앙박물관, 국립현 대미술관, 부천시 박물관 〈감각의 확대, 관계의 확장> 전시, 대한민국역사박물관에 관하여 사례 분석 중심으로 조사되었다. 국립중앙박물관과 국립현대미술관(과천관) 의 경우 서비스 등의 보완 필요성 제기, 부천시 전시의 경우 장애에 대한 새로운 관점 제시했다는 점에서, 대한민국역사박물관의 경우 유니버설디자인 적용의 선례 로 제시하고 있다. 해외 정책사례로는 유럽, 미국, 일본으로 구분하였으며, 주요 내 용으로는 장애 없는 관광(배리어프리 투어리즘)이 주를 이루고 있다.

2013년 유니버설디자인 가이드라인 연구는 시설 설치 조건을 중심으로 문화시설 공통(매개, 내부, 위생, 안내, 홈페이지), 문화예술회관(공연장, 전시장, 강연장, 기 타시설)에 적용되는 시설 기준 가이드라인 제시하였다. 전시장의 경우 출입구 및 통 로, 전시물(벽면, 공간, 촉각), 조명, 전시관람 지원시설(해설판, 음성해설장치, 전시 가이드 단말기, 인터렉티브 장치, 유인물, 인적서비스), 휴식용 벤치 및 의자, 안내사 인, 전시 프로그램(투어 및 워크숍, 체험전시), 강연장(강연안내, 공간계획, 설비, 강 연내용 전달), 지원시설(안내데스크, 매표소, 물품보관소, 수유실, 놀이방, 음료대, 자동판매대) 등의 일반 가이드라인 제시하고 있다. 일본과 스위스의 기준을 참고하 여 유니버설디자인 적용을 위한 체크리스트 제시하였는데 시설에 대한 내용이 주를 이루고 있어 포괄적인 의미의 문화서비스에 대한 접근성을 다루지 못하였다.

\section{라. 한국관광공사(2015), 「장애물없는 관광 시설 및 서비스 가이드라인 구축」}

관광분야 장애인 접근성 관련 가이드라인 연구로, 장애물 없는 관광의 의미와 가 치, 장애물 없는 관광시설 가이드라인, 장애물 없는 관광서비스 가이드라인, 향후 추진방향 및 계획으로 구성되었다. 관광시설 가이드라인에 이용시설로 박물관.미술 관 사례 수록되어있으며, 유니버설디자인의 기준을 따르고 있다. 
장애에 대한 이해가 선행된 서비스 제공(에티켓, 언어사용 등)과 이용자 중심의 서비스 이용/환대(welcoming) 차원의 서비스 가이드라인을 해외정책사례와 함께 제시하고 있어 기존의 연구가 편의 시설에서 발생되는 소극적 의미의 서비스 가이 드라인을 제시한것과 차별점을 찾을 수 있다.

\section{마. 기관별 장애인 가이드라인 관련 선행연구}

그 외 국립 박물관-미술관 차원에서 장애 대상별 교육 프로그램 개발을 위한 연 구보고서 내용을 통해서 장애인 관련 프로그램 및 서비스 가이드라인의 방향 등을 일부 찾아볼 수 있다. 국립현대미술관(2012), 「특수아동을 위한 미술관 교육 활성 화 방안 연구」의 경우, 국립현대미술관 교육 프로그램을 중심으로 특수미술교육에 대한 이해, 사례 조사, 국립현대미술관 어린이 미술관의 활용, 새로운 프로그램 제 안 등이 제시하고 있다. 특수교육의 관점에서 장애아동들에 대한 학습 양식을 분석 하여 이에 대한 교육 관점 및 방식을 제시하였다.

국립한글박물관(2018), 「국립한글박물관 장애인 대상 교육 프로그램 개발」의 경 우, 국립한글박물관의 장애인 잠재 수요조사, 특수교육 교육과정 및 학습방법, 장애 인 대상 서비스 현황, 프로그램 제시 등으로 구성하고 있다. 국립현대미술관 보고서 (2012)와 마찬가지로 특수교육의 특수성을 반영한 교육프로그램 개발을 위한 기초 자료로 박물관 교육과정에 대한 분석과 박물관 환경에서의 발달장애학생의 특수 교 육을 중점적으로 다루었다. 외부 연구진이 아닌, 해당 박물관 연구교육과 중심으로 연구진을 구성하고, 외부연구진의 자문을 받아 실질적으로 박물관(한글을 주제로 한 특성화 박물관)에 적용이 가능한 프로그램을 제시했다는 점에서 타 연구와 차별 적으로 볼 수 있다. 


\section{제2절 박물관·미술관 장애인 접근성 가이드라인 사례 분석}

살펴본 바와 같이 국내에서는 아직 박물관.미술관 환경에서의 장애인 접근성 가 이드라인이 발간된 바가 없는 상황으로, 본 절에서는 차후 국내 박물관-미술관 환경 에서의 가이드라인 수립을 위한 선례로써 해외에서 이미 발간된 유형별 대표 가이 드라인을 분석하고자 한다.

박물관·미술관 장애인 가이드라인의 경우 특수한 목적을 가진 서비스를 제공하기 위한 목적을 두고 있어 시설 지침과 서비스 지침이 분리된다고 보기 어렵다. 이에 국내의 박물관.미술관의 장애인 접근성 강화를 목적으로 한 가이드라인의 경우 박 물관-미술관의 전문공간에서 필요한 설치물들에 대한 시설 가이드라인과 서비스 가 이드라인을 종합적으로 바라보는 관점에서 수립될 필요가 있다. 또한, 수립을 위한 방향성을 제시할 위해서는 세부적인 시설 지침보다 앞서 기본 원칙과 방향을 정리 할 필요가 있다. 이에 심층 사례 분석의 경우 살펴본 선행 가이드라인 중 '가이드라 인 수립의 방향 을 제시하고 있으며 이 방향에 따라 시설과 서비스 가이드라인을 종합적으로 다루고 있는 사례를 중심으로 살펴보았다. 특정 박물관-미술관에서 발 간된 보고서의 경우 해당 환경에서의 특수성이 반영될 수 있는 점을 고려하여, 국가 보고서 또는 박물관 연합 차원의 가이드라인을 중심으로 분석하였다.

각각의 가이드라인이 발간된 배경과 목적을 우선으로 살펴봄으로써 가이드라인 발간을 위해 필요한 정책적 제반 환경을 이해하고자 하였다. 또한, 가이드라인의 내 용과 연구 방법론을 통해 구체적인 가이드라인의 전반적인 구성 요소들을 검토하였 다. 마지막으로는 가이드라인 발간 이후의 이뤄진 정책적 후속 조치 등을 살펴봄으 로써, 실질적으로 박물관-미술관 현장에서 가이드라인이 적용될 수 있는 방안에 대 한 시사점을 분석하였다. 


\section{The Council for Museums Archives and Libraries (1997), Disability Directory for Museums and Galleries}

\section{가. 배경과 목적}

영국 박물관·도서관·아카이브 협의회19)가 발간한 가이드라인으로 모든 박물관과 미술관이 장애인에 대한 서비스를 개선할 수 있도록 이를 안내하는 목적으로 만들 어졌다. 1993년 처음 발행되었으나, 1997년 내용을 갱신하여 재 발간하였다. 가이 드라인 갱신 및 재 발행은 영국에서는 1995년 장애인차별법(DDA)에 시행에 따라 관련 서비스 제공자들이 이행해야 할 의무 이행이 1999년 10월부터 발효됨에 따라 이를 수행할 수 있는 지침의 일환으로 이뤄졌다. 이후 2000년 4월부터 장애인권리 위원회(DRC)20)가 업무를 시작했으며 2000년 10월부터 영국에는 인권법(Human Rights Act)이 제정되었다. 또한 2000년 1월부터 이와 장애인 차별에 관한 법이 교육 분야의 법안(Education Bill)에 확장 반영되는 등 장애인 차별에 대한 다양한 분야에서의 의무가 시행됨에 따라, 교육과 문화 분야에서의 움직임도 활발해졌다. 또한 2000년 4월부터 Resource: The Council for Museums, Archives and Libraries이 발족되어 이와 관련한 활동을 주도적으로 할 수 있는 체계가 마련되었다.

\section{나. 가이드라인의 구성 및 세부 내용}

이 가이드라인은 비장애 중심의 사회적 담론과 물리적 환경 등이 장애를 만들고 있다는 사회적 모델(social model of disability)와 장애를 성별, 인종, 계급, 종교, 성적 지향 등과 마찬가지로 하나의 정체성(identity)와 문화로 수용하는 소수자 모델 (minority model of disability)를 지향하고 있으며 크게 세 파트로 구성되어있다.

먼저 1장은 박물관 및 미술관에서의 장애인 접근성과 관련한 원칙과 관련 통계, 용어, 법률에 대한 설명을 통하여 박물관·미술관에서의 장애인 서비스 제공의 방향 을 제시하였다. 특히 접근성의 이슈를 세분화하고 이를 증진하기 위한 원칙을 다양

19) 2012년 5월까지 운영되었으며 현재는 없어진 비정부기구(non-departmental public body and registered charity in England)

20) The Disability Rights Commission 
성(diversity), 포용적 실천(inclusive practice), 지속가능성(sustainability), 사회 적 포용(social inclusion), 책무성(Accountability) 으로 제시하여 박물관·미술관 에서의 장애인 서비스 제공에 대한 당위성을 제공하였다. 장애인 접근성 개선을 위 한 실무 지침과 모범사례를 다룬 2 장에서는 다음의 10 개의 주제 분류를 통하여 각 주제별로 일반 지침과 세부 내용을 기술하고 있다.

- 운영체계(institutional framework \& structures), 운영정책(policies), 진단 (consultation), 직원교육(training), 접근성에 대한 진단도구(access audits), 접견공간 및 방문자 관리(front of house \& visitor care), 마케팅 및 홍보 (marketing \& publicity), 전시기법과 해석(display \& interpretation), 박 물관과 포용측면에서 교육의 역할(educational role of the museum and inclusion), 자금 확보(funding)

3장에서는 참고자료와 관련한 사이트 및 연계기관 등의 정보를 수록하여 현장에 서 이 가이드라인을 적용하는 데 필요한 정보를 수록하고 있다.

\section{다. 시사점 및 후속 조치}

본 가이드라인은 영국에서 장애인차별법 시행과 함께 만들어진 최초의 박물관·미 술관 분야 가이드라인으로서 박물관·미술관의 현재 및 잠재적 사용자와의 협의의 필요성, 박물관 또는 미술관의 모든 활동에 걸친 포괄적 사고의 촉진 및 접근을 개 선하기 위한 ICT의 효과적인 사용을 강조하면서 모범사례를 뒷받침해야 하는 원칙 을 개략적으로 설명하고 있다. 박물관과 미술관이 장애인에게 정책을 검토·개발하 고 서비스를 제공할 때 활용할 수 있는 실질적인 조언이 될 수 있도록 구체적인 사 례 등을 담아 설명하였다.

"본 가이드라인은 접근성 장벽을 제거함으로써, 박물관과 미술관이 사회적 배제 를 해결하는 데 도움을 줄 수 있고, 모두를 위한 즐거움, 학습, 영감의 장소가 될 수 있다는 것을 보여준다. 그것은 또한 그 과정이 다양성을 인식하고 평가함으로써 직원, 자원봉사자, 방문객 그리고 박물관과 미술관에 관련된 모든 사람에게 혜택을 
주는 보다 긍정적이고 창의적인 문화를 촉진하리라는 것이다."21)

서문에서 밝힌 것과 같이 이 가이드라인은 당시 영국 노동당 정부가 사회적 포용의 주요 사업의 전진 기지로 박물관.미술관의 사회적 역할을 강조했던 정책 추진의 방향 과 그 맥락을 함께 하고 있음을 알 수 있다. 즉, 장애인이 사회적으로 배제되지 않고 평등한 기회를 누릴 수 있는 복지 정책 아젠다와 그에 부합하는 실무 지침 방향을 명확히 제시하고 이를 뒷받침할 수 있는 정책 도구들을 후속 조치로써 마련하였다.

\section{1) MLA(2003), Resources: Disability Portfolio Guide}

일반인과 현장 실무자를 위한 핸드북 형식의 장애인 서비스 제공에 대한 안내 책자 로 총 12 개의 테마를 구분하여 장애인이 필요로 하는 서비스에 대하여 일반 사용자와 박물관 직원들이 이해해야 하는 영역을 설명하고 있다. 각각의 테마는 다음과 같다.

- Disablilty in Context: 장애인들이 어떻게 사회에 적응하는지에 대한 이해를 얻고 어떤 요소들이 그들의 서비스 선택에 영향을 미치는지에 대한 내용

- Meeting Disabled People: 서비스 사용자, 고객, 동료 및 자원봉사자로서 장 애인과의 직접적 상호작용을 하는데 필요한 조언들

- Training for Equality: 조직 내에 장애 서비스와 관련한 직원교육 실시 내용 및 과정을 설명함 또한 이를 교육할 수 있는 전문강사를 선별하는 방법 제시

- Audits: 장애인 서비스에 대한 감사를 수행해야 하는 이유를 이해하고 원하는 유형의 감사를 식별하고 이를 누구에게 맡기고(감사 집행자) 어떠한 절차로 진 행해야 하는가에 관한 내용

- Disability Discrimination Act(DDA): 장애인 차별에 관한 법시행이 박물관, 아카이브, 도서관에 어떠한 방식으로 적용되어야 하는지에 대한 이해

- Inclusive Information: 정보를 받고자 하는 사람에 특성을 아우르는 포용적 인 방식의 정보제공의 노하우 제시

21) MLA(1997) p.9: "The Directory shows that by dismantling these barriers museums and galleries can help to tackle social exclusion and become places of enjoyment, learning and inspiration for all. It also demonstrates that the process will promote a more positive and creative culture which, by recognising and valuing diversity" 
- Using Technology: 장애인이 어떠한 기술적 방법을 통하여 일상생활을 영위 하고 있는지를 이해하고, 이를 지원하려는 방안 제시

- Access on a Shoestring: 예산 비용의 과다한 지출 없이 사람들에게 더 나은 접근성을 제공할 방안 제시. 이 가이드에서는 비용에 영향을 미치지 않는 계획 수립 및 운영의 노하우를 제공하여 관련 서비스 제공의 비용적 한계 타진을 위 한 실질적인 방안 제시함

- Accessible Environments: 다양한 요구사항을 가진 장애인들의 접근가능한 공간 및 시설 환경을 만들 때 고려해야 할 사항

- Outreach and Partnerships: 지역사회에서 프로젝트와 파트너쉽을 개발하고 유지하기 위하여 방안

- Consulting Disabled People: 장애인 상담에 대한 안내, 혜택 및 사용, 컨설 팅 방법, 프로세스 계획 및 준비 방법, 접근성 있는 방식으로 수행하는 방법에 대한 안내를 제공

- Employment at Every Level: 직원, 자원봉사자, 수탁자 등 모집과 유무를 고려할 때, 직장 내 모든 장애인의 공정한 대우를 보장하는 방법에 대한 실질적 인 조언

2) $\operatorname{MLA}(2003)$, Access for All Self-Assessment Toolkit

상기의 디렉토리형 가이드라인 및 실무자용 안내 가이드를 기초로 한, 각 항에 내용 과 연계된 장애인 친화 운영을 위한 기관 자가진단표을 제시하여 기관별로 자체적인 관련 운영정책 및 사업을 구성할 수 있도록 자료를 제공하고 있다. 자가 진단표를 활용 하기 위한 체계를 제시하고 각각에 대한 세부 내용은 앞에서 살펴본 가이드라인을 참고 하면서 평가할 수 있도록 하고 이를 기관에 맞는 액션플랜을 수립할 수 있도록 하였다. 즉, 단순한 평가 체계가 아닌 실질적으로 운영에 이바지할 수 있도록 구성하였다. 총 10 개의 영역 30 개의 지표, 88 개의 항목으로 구성되어있으며 세부 지표 내용은 정책과 운영(Policy/Management), 장애인 접근성 감사(Disability access audits), Staff training(직원교육), Employment(고용), Consultation and feedback(컨설팅과 피 드백), Information and publicity(정보제공과 홍보), Collections and displays(컬 
렉션과 전시배치), Learning and Outreach(교육과 아웃리치), Technology and equipment(기술과 지원도구), Building and public space(시설과 공용공간) 이다.

\section{Australian Museum/National Museum of Australia(2005), Many Voices Making Choices: Museum Audiences with Disabilities}

\section{가. 배경과 목적}

호주 박물관과 호주 국립 박물관, 캔버라가 주관한 본 연구보고서는 선행된 Energised, Engaged, Everywhere: older audiences and museums(2002), Knowledge Quest: Australian families visit museums(2004)의 후속연구로 진 행되었다. 선행된 연구들이 방문객 및 65세 이상의 고령 방문자에 관한 내용을 다 룸에 있어 접근(access)에 관한 정보를 얻는 데는 충실했지만, (지적 접근성의 의미 로) 예술 및 (정보접근성에 대한) 박물관에 관한 내용은 거의 다뤄지지 못했다는 데 에 착안하여 작성되었다. 물리적 접근성이 아닌 지적 접근성과 정보접근성은 장애 인의 시각에서 이해되어야 하는 까닭으로 시드니와 캔버라에서 관련한 설문조사와 워크샵, 이해관계자 인터뷰 및 간담회 개최 등을 통하여 자료를 수집하였다. 직접 이해관계자인 시각, 청각, 지체 장애인은 물론 '다른 언어'를 쓰는 원주민들, 그리고 관련 서비스를 현장에서 제공하는 박물관 직원, 박물관 최고 관리자, 장애인 보호자 를 포함한 워크솝도 진행되었다.

조사 시, 박물관 방문 동기, 박물관 방문에 미치는 요인, 박물관 방문의 장벽, 최 근 방문 시 경험에 대한 자세한 설명(높음 및 낮음 포함), 박물관이 제공하는 지식정 보의 수준, 전시 주제 및 프로그램, 인터넷 및 여가활동 개별 습성을 고려하여 수행 되었다. 


\section{나. 내용 구성}

장애인의 박물관 접근성에 대한 질적 접근으로, 박물관 방문 목적, 방문에 영향 을 미치는 요인, 방문에 장애를 주는 요인, 최근 방문에 대한 구체적인 소감 (description), 박물관에서 제공하고 있는 지식의 깊이, 전시 주제와 프로그램, 인 터넷과 여가 향유 행태에 대한 논의를 질적 방법론에 따라 기술하고, 권고문형식으 로 가이드라인 제시하였다.

보고서는 보고서에서 다루는 대상은 지체 장애인, 시각장애, 청각장애, 지적 장애 인을 포괄하며, 다음의 6장으로 구성되었다. 1. 서론(장애 개념과 현황) 2. 접근성을 개선하기 위해서? 3. 박물관과 미술관의 방문 과정 4. 전시 접근성 개선 5. 직원이 알아야 할 것들 6 . 주요사항과 추천 사이트

각 장과 세부 절의 제목에 부제로서 질적 조사를 통해서 발췌한 조사 대상자들의 의견을 '직접 인용'하여 내용에 대한 체감을 높였다.

보고서의 1 5장까지는 주요한 사안에 대하여 기존에 조사 연구되었던 양적 연구 결과를 바탕으로 질적 조사결과를 정리하는 방식으로 기술되었으며, 6장의 주요사 항(Key Finding)은 질적 조사의 결과를 반영하여 단문 형식의 구체적인 상황에 대 한 주의사항을 제시함으로써 가이드라인의 가독성을 높이고 내용을 즉각적으로 이 해할 수 있도록 정리하였다.

\section{다. 시사점 및 후속 조치}

본 가이드라인은 기존의 물리적 접근성을 중심으로 방문객 또는 방문 행태를 파 악하여 장애인을 포함한 상대적 소수의 어려움을 겪고 있는 방문객의 불편을 해소 차원에서 이뤄졌다. 접근성의 문제를 단순히 물리적인 접근성뿐만 아니라, 정보, 경 제적, 심리적 접근성 등으로 세분화하여 각각의 장벽에서 발생하는 문제에 대한 개 선 방향을 제시하는 근거를 마련하였다.

또한, 문화예술에 대한 창조적인 참여를 인권의 하나로 보고 있으며, 문화예술 활 동 참여 등을 통하여 지역과 사회에서 배제되지 않을 수 있다고 보았다. 특히 고령 화로 발생하는 장애의 경우(age-related disability) 문화예술기관에서 진행되는 프로그램에 참여함으로써 사회적으로 분리되지 않을 수 있다고 보고 박물관·미술관 
을 포함한 문화예술기관의 관련 프로그램 기획의 중요성 강조하고 있다.

이후 호주 박물관 연합(Australian Museums, 2015) 차원의 박물관.미술관 장 애인 관련 실행 계획(Disability Inclusion Action Plan)의 근거로서 본 연구가 활 용되었다고 볼 수 있다.

\section{DCMS(2008), Secretary of State Report on Disability Equality Department for Culture Media and Sport}

\section{가. 배경 및 목적}

앞서 살펴본 1997 년의 가이드라인은 1995 년과 2010년 사이에 이루어진 장애인 차별에 관한 법·제도의 정립과 더불어, 창조산업을 중심으로 문화예술 및 문화산업 의 사회적 가치와 경제적 가치를 강조한 노동당 정부(1997 2010) 시기에 이뤄진 박물관·미술관 분야에서의 장애인 접근성 개선의 결과였다(정종은, 2019). 이후 영 국 문화·미디어-스포츠부에서는 부처에서 담당하고 있는 정책 분야에 대한 장애인 제도 및 정책 공유를 통하여 이에 대한 장애인 평등의식의 확산 노력을 해왔다.

본보고서는 박물관-미술관 분야를 비롯하여 영국 문화·미디어·스포츠부에서 아 우르고 있는 문화·예술·체육·미디어의 공공 분야에서 이뤄지는 장애인 친화적 제도 운영 및 예산에 대한 현황 소개하고, 각각의 분야별 장애인 친화 정책 및 제도 운영의 원칙과 주요 정책 이해관계자들과 그들의 활동을 사례와 함께 소개하고 있다. 이 보고서는 정부 장애인 정책 자문 기구인 Equality 202522)의 의견을 받아 작성되었 고 장애인 친화적 정책 추진의 모범사례 등이 개발될 수 있도록 도움을 받았다.

22) a body of publicly-appointed disabled people, offered strategic, confidential advice to government on issues that affect disabled people. 


\section{나. 내용 구성}

이 보고서의 각 장은 특정 정책 영역(총 12 개의 분야23)로 구성)을 다룬다. 정책 분야에 종사하는 공공기관과 장애 평등 촉진에 관심이 있는 우리와 함께 일하는 핵 심 파트너에 대해 간략히 설명한다. 각 장의 두 번째 부분은 다양한 정책 분야의 공공기관이 장애 평등을 향해 더 나아가기 위해 어떤 조치를 취하고 있는지를 개략 적으로 설명한다.

장애 평등에 관한 성과는 각 장에 부문별로 요약되어 있다. 우리는 무엇이 성취되 었고 이것이 개별 장애인에게 무엇을 의미하는지 설명하기 위한 사례와 이를 뒷받 침할 수 있는 데이터를 함께 수록하여 질적-양적 성과를 함께 나타내었다. 현재의 진행 상황과 이후 후속 조치 등을 설명하고, 관련한 후속 조치와 관련된 정책 이해 관계자들의 협력 체계도 기술되었다. MLA 소관으로 박물관.미술관 분야의 경우 다 음의 4 가지 원칙을 기초로 하여 운영되고 있으며, 관련한 구체적 사업과 성과를 기 술하였다.

- 건축물의 물리적 배치에 있어서 장애 차별법을 준수

- 사용자에게 친숙한 기호 및 디스플레이 제공

- 소장품 및 전시회에서 장애 표현

- 다양한 요구(예: 청각적 또는 시각적 장애)를 위한 특정 시설관리

보고서는 2006년부터 시작된 '크리에이티브 파트너십(Creative Partnerships)' 프로그램을 통하여 확산한 '포용적 예술(inclusive arts)' 개념(정종은, 2019) 하에, 박물관·미술관에서 장애인 평등이 접근성 개선 및 사용자 맞춤 환경 조성뿐만 아니라, 관련한 콘텐츠의 재현(representation)에 있어 편견을 해소에 대한 공공기관의 노력 이 중요하다고 보았으며, 관련 대표 사례로 〈Rethinking Disability Representation PROJECT>를 소개하였다.

23) 예술, 건축과 역사 유적, 왕립공원, 박물관-미술관 및 도서관, 복권기금사업, 사행산업과 인증 영역, 창조 산업, 영화, 방송, 체육, 관광, 2012 올림픽 및 장애올림픽 위원회 


\section{다. 시사점 및 후속 조치}

공공부문에서의 장애인 평등을 위한 의무 이행의 중요성과 이를 통해 국가 전체의 인식 개선의 효과를 기대한 본보고서를 통하여 정부의 장애인 평등 의무 수행의 성과 를 확인하고 이후 후속 사업 이행의 가이드라인으로서 보고서의 의의를 찾을 수 있다.

당시 2012년 런던올림픽을 문화올림픽으로 추진하고 있었으며, 중심 부처인 문 화-미디어-스포츠부에서 장애인에 대한 다양한 성과와 진행 상황 및 후속 조치 등 을 망라하여 보고서로 정보를 공유함으로써 공공영역은 물론 민간영역에까지 일종 의 정책 '가이드라인' 역할을 하게 되었다고 볼 수 있다. 2012년 런던올림픽 개·폐 막식에서 언리미티드(Unlimited) 프로그램을 통하여 영국의 장애 예술이 전 세계 에 선보여지게 될 수 있었던 것은 이와 같은 정부의 축적된 노력의 결실이라고 볼 수 있으며, 이후 잉글랜든 예술위원회의 10 개년 주요 계획 주요 목표로 '다양성과 솜씨(Diversity and skills)'을 설정하고, 집중적으로 장애 예술 진흥을 할 수 있는 여건 마련에 이바지했다고 볼 수 있다.

\section{EU(2017), Report on the Accessibility in Central Europe}

\section{가. 배경과 목적}

본 보고서는 $\mathrm{EU}$ 의 중부 유럽, 특히 중소 박물관의 문화 접근성의 개선을 목적으로 COME-IN!(박물관에 대한 온라인 차원의 개방적 접근을 위한 협력 프로젝트)의 목 적으로 작성되었다. COME-IN!(COME-IN!) 프로젝트는 Interreg CENTRAL Europe Program ${ }^{24}$ )에 따라 자금을 지원하고, 중부유럽의 문화유산에 대한 가치 제고를 위 해 진행된 프로젝트로, 이 보고서의 근거는 COME-IN의 정의된 원칙뿐만 아니라, 유엔 장애인권리협약과 포괄성과 접근성에 대한 이해를 바탕으로 하고 있다.

COME-IN! 프로젝트는 모든 사람이 중앙 유럽 문화유산에 접근할 수 있도록 협 력 박물관의 온라인 기술 역량을 향상하고자 진행되었다. 실제로 접근성 향상을 통 한 중앙 유럽 문화유산의 가치 연계 활용은 이 지역의 지속가능한 사회경제적 발전

24) EU 차원의 범국가적 기금으로 민관 협력 차원에서 중부 유럽의 다양한 여건을 개선하기 위해 운영되고 있음 
에 이바지할 것을 기대하고 있다 이 프로젝트는 모든 종류의 “문화 현장”에 초점을 맞추고 있으며, 특히 중소규모의 박물관을 방문하는 장애가 있는 사람들을 위하여 준비되었다. 이 프로젝트의 최종적 비전은 모든 공감각적 체험을 통하여 문화에 대 한 몰입감 있는 경험을 제공하는 것이다.

가장 먼저 중앙 유럽에서 추진될 접근성 표준을 식별하기 위한 목적으로 “접근성 기준”을 정의하고자 하는 모든 사용자의 요구와 예술의 상태를 분석하기 위하여 협 력 박물관25)의 이해관계자와 파트너들의 의견을 수렴하는 과정을 통하여 지표를 완 성하였다. 이를 기준으로 추후에 중앙 유럽권의 박물관.미술관의 장애인을 포함한 방문객 접근성 개선을 기대할 수 있게 되었다.

\section{나. 내용 구성}

내용은 크게 4 개 분야로 구분되어있다. 협력 박물관의 협의를 통해서 완성된 접 근성 지표를 통하여, 현재 상황을 점검하고, 접근성 개선을 위해 필요사항을 보여주 었다. 유엔 협약에 따른 접근성의 다양한 측면과 아울러 중소 박물관을 위한 서비스 체인을 포함매트릭스를 사용하여 접근성을 개선하기 위해 중소 박물관이 반드시 갖 춰야 할 필수 조건을 설명하고 있다.

또한, Law Framework 장에서는 UN 장애인의 권리에 관한 협약, 유럽 장애 전 략 2010 2020 및 관련 EU-Directives를 분석하여 CE 국가의 비교를 통해 모든 국가가 유엔 협약에 서명하고 장애인을 차별로부터 보호하기 위한 법체계를 가지고 있고 이를 어떠한 방식으로 활용할지에 대해서 기술하였다.

마지막으로, 타 박물관의 온라인상의 정보 및 지식 접근성 우수 관리 기준 사례를 살펴봄으로써 매트릭스와 연계하여 보고서의 이론적 부분을 실제 예제로 뒷받침하였다.

특히, 접근성 매트릭스에 대한 현 상황 진단에 있어 박물관·미술관의 서비스 체 인(세로축)에 따른 분석법을 통하여 박물관 방문객에게 발생할 수 있는 모든 상황을 살펴보고자 하였다. [그림 3-1]에서 보는 바와 같이 일반적인 체험을 기준으로 하여 각 박물관에 따라 이를 선별적으로 조정할 수 있도록 하였다.

25) Archaeological Museum, Civic Museum and Gallery of History and Art, Udine, Maritime Museum "Sergej Mašra" Piran, Museum of the Working World, Archaeological museum of Istria, Thuringian Museum of Pre- and Ancient History,Archaeological Museum in Krakow. 
매트릭스의 가로축에는 유형별 접근 장애 요소를 배치하였는데, 물리적, 정보 및 소통, 사회적, 경제적 접근 장애의 4가지 요소를 통해 매트릭스를 구성하고 각각의 세부 평가 항목을 배치하였다.

[그림 3-1] 박물관-미술관의 서비스 체인

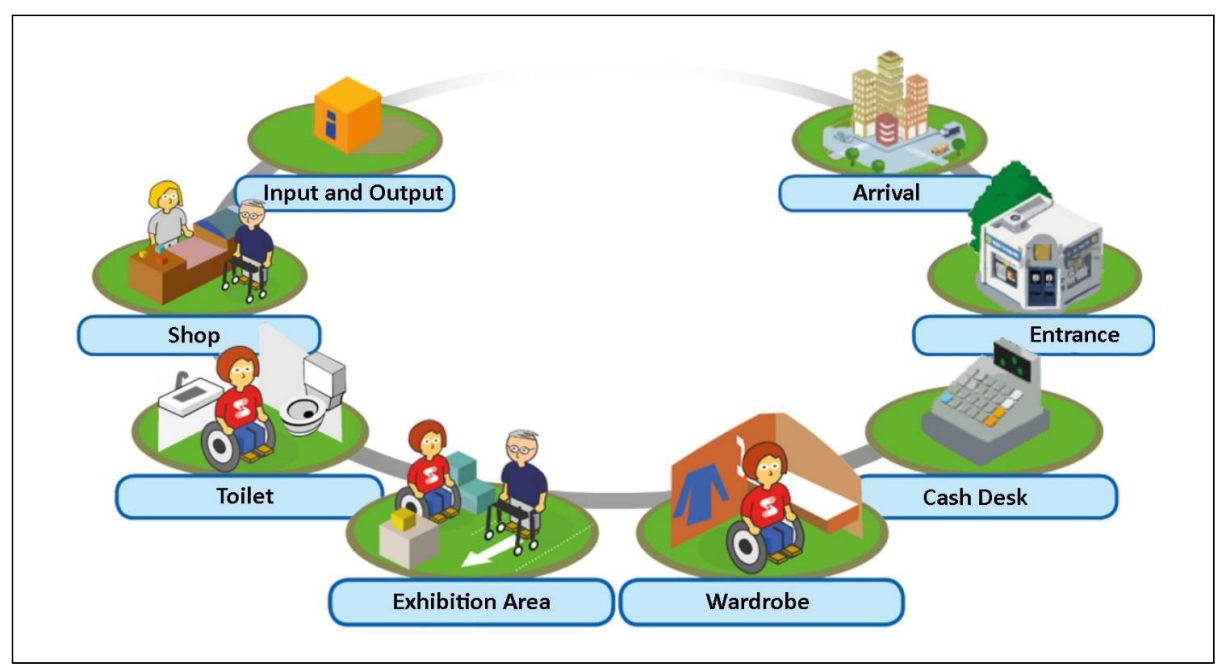

출처: EU(2017), Report on the accessibility in Central Europe, p.11

\section{다. 시사점 및 후속 조치}

본 가이드라인은 접근성과 관련한 다양한 이슈를 매트릭스로 유형화하여 현 상황 을 진단하고 이러한 진단에 기초한 접근성 개선의 가이드라인을 제시하고 자 했다 는 점에서 방법론적으로 시사하는 바가 크다. 또한, 타 기관의 선례 등을 공유하여, 좀 더 나은 방향으로 개선할 수 있도록 돕는 '가이드라인' 으로서의 기능이 있다.

특히 범국가적인 단위에서 진행된 프로젝트로서, 중소 박물관·미술관의 환경을 고려하여 작성되었다는 점과 접근성의 문제를 파악하기 위하여 박물관 방문에서 벌 어지는 다양한 상황을 서비스 체인으로 하여 분석하였다는 점이 눈에 띈다. 각 박물 관·미술관이 가진 상황을 고려하여 매트릭스의 구분과 항목을 상황에 맞춰 조절 평 가할 수 있도록 하여 지표를 통해서 놓칠 수 있는 개별 상황에 대한 파악을 보완하 였다. 
〈표 3-2〉 접근성 메트릭스: 방문 전 정보 및 소통 단계

\begin{tabular}{|c|c|c|c|c|}
\hline $\begin{array}{l}\text { Accessibility } \\
\text { Service } \\
\text { Chain }\end{array}$ & $\begin{array}{l}\text { Physical } \\
\text { access }\end{array}$ & $\begin{array}{l}\text { Access to information } \\
\text { and communication }\end{array}$ & Social access & Economic access \\
\hline $\begin{array}{l}\text { Input } \\
\text { Information } \\
\text { and } \\
\text { communication } \\
\text { before the visit }\end{array}$ & - & $\begin{array}{l}\text { Website Social } \\
\text { Network, other } \\
\text { Websites } \\
\text { - On Level A/AA/or } \\
\text { AAA(W3C) } \\
\text { - Audio and video } \\
\text { description } \\
\text { - Easy to read } \\
\text { Good Practice: } \\
\text { See } 7.8 \text { Museums Story } \\
\text { Guide and Annex A: } \\
\text { Early Birds visual story } \\
\text { and Museums Story } \\
\text { Guide; } \\
\text { 7.2 Salzburg Museum; } \\
\text { 7.11 National Museum } \\
\text { in Krakow(Muzeum } \\
\text { Narodowe w Krakowie); } \\
\text { 7.10 Historical Museum } \\
\text { of the City of Krakow } \\
\text { (Muzeum Historyczne } \\
\text { Miasta Krakowa) } \\
\text { Accessibility statement } \\
\text { (Which services are } \\
\text { offered?) } \\
\text { Accessible } \\
\text { Information about: } \\
\checkmark \text { Tactile trails and } \\
\text { electronic description }\end{array}$ & $\begin{array}{l}\text { - Is the } \\
\text { museum } \\
\text { prepared to } \\
\text { address and } \\
\text { to deal with } \\
\text { disabled } \\
\text { visitors? } \\
\text { - Inclusive } \\
\text { guiding } \\
\text { toure(mixed } \\
\text { groups) } \\
\text { Participation } \\
\text { of and } \\
\text { collaboration } \\
\text { with } \\
\text { associations } \\
\text { of people with } \\
\text { disabilities or } \\
\text { schools } \\
\text { Inform and } \\
\text { involve the } \\
\text { target group } \\
\text { (including the } \\
\text { families: } \\
\text { attractive } \\
\text { offers not only } \\
\text { to people with } \\
\text { disabilities, } \\
\text { but also to } \\
\text { people with } \\
\text { disabilities } \\
\text { together with } \\
\text { their family or } \\
\text { friends) }\end{array}$ & $\begin{array}{l}\text { Information to the } \\
\text { fees: } \\
\text { - Free of charge } \\
\text { or } \\
\text { - equal service } \\
\text { for equal } \\
\text { price(same } \\
\text { costs for } \\
\text { visitors with } \\
\text { and without } \\
\text { disabilities but } \\
\text { no further costs } \\
\text { for personal } \\
\text { assistance } \\
\text { service) }\end{array}$ \\
\hline
\end{tabular}

출처: EU(2017), Report on the accessibility in Central Europe, p.12 


\section{5. 프랑스 문화부(2017), Guide Exposition et Parcours de Visite Accessibles}

\section{가. 배경 및 목적}

프랑스 문화통신부는 1993년 UN에서 선포한 장애인에 대한 평등 조항의 원칙의 후속으로 2005년 “평등한 권리와 동등한 기회를 위한 장애인의 참여와 시민권에 관한 법률"(loi "Pour l'egalite des droits et des chances, la participation et la citoyennete des personnes handicapees") 제정이후, 2007년부터 문화부문 에서 장애인 접근성과 관련한 일련의 현장가이드 북(일반개론, 2007)을 발간하기 시작하였다. 이후 〈공연예술 분야〉(2009)〈정신 장애인 수용(가능) 문화장소〉(2010) 를 발간하였다. 2016년 발간된, 본 지침은 박물관-미술관을 대표되는 전시공간에서 의 방문 접근성에 대한 지침서로서, 장애인의 문화예술 활동의 대표적인 공간이자 장소인 박물관·미술관에서의 전시 및 관람(동선)에 대한 접근성 개선을 위한 실무적 인 지침으로 구성하였다.

본 지침서들의 목적은 크게 세 가지이다. 가장 먼저 장애인들의 문화예술 활동에 대한 불편을 해소하고 다양한 요구를 수용하는 차원이다. 또한, 이러한 장애 해소를 통하여 문화예술을 누리고 즐기는 데 있어 보다 많은 대중에게 편안한 환경을 제공 하고 함을 목적으로 한다. 최종적으로는 문화향유에 대한 국민적 관심을 높여 더 많은 잠재적 관람객을 넓히는 데 목적을 두고 있다.

\section{나. 내용 구성}

본 지침서는 서론과 2 개의 장으로 구성되어있으며 서론에서는 접근성의 범주와 개념, 유니버설디자인의 원칙을 다루고 있다. 1 장에서는 장애인 접근에 대한 관점 적용된 전시를 구성하는 데 있어서 필요한 책무와 발생하는 상황에 대해서 단계별 로 구체적으로 기술하여 가이드라인 적용에 대한 이해를 높이고 있다. 2장에서는 전시장 구성 시, 실무에서 적용되는 요소별 가이드라인을 분야별로 구분하고 각각 에 필요한 인체공학적 분석과 설계의 지침을 설명하고 있다. 각 분야는 전시 디자인 (La scénographie d'une exposition), 전시에 필요한 진열장 등(mobilier), 조명 
(éclairage), 그래픽과 표지판(signaletique et graphisme), 음향(son), 멀티미디 어(multimedia), 전시보조기구(expôts) 으로 구분되며, 전시를 기획하고 구성하고 설치하면서 필요한 세부적인 정보를 담고 있다. 특히, 전시의 구성단계를 초기 기획 에서 완성단계에 이르기까지 세세하게 구분하고 이에 대한 필요 요구사항과 고려해 야 할 점을 일목요연하게 정리하고 있다. 또한, 전시 동선에서 발생할 수 있는 위험 과 간격 및 거리 등을 고려한 인체공학적 내부 설계를 기획할 수 있는 가이드라인 등을 이미지와 함께 제시하여 전시 준비를 수행하는 기관의 내부 직원은 물론, 외부 에서 전시 제작 등을 진행하고 있는 민간영역의 사업자들에게 유효한 정보를 제시 하고 있다.

\section{다. 시사점 및 후속 조치}

지침서의 구성과 편집은 2007년 가이드라인 발간 때부터 이와 같은 형태를 유지 하고 있으며, 감각적인 디자인과 다양한 도표와 이미지를 활용하여, 독자가 쉽고 빠 르게 정보를 취득할 수 있도록 정리되었다. 특히 실무 지침서로 활용할 수 있는 다 양한 상황을 이미지로 표현하여 정보 전달력을 높였음을 알 수 있다.

지침서의 내용은 인체공학과 다양한 공학적 설계를 위한 과학적 분석 결과가 뒷 받침되어있어, 신체장애로 인해 이용에 불편이 발생하는 장애인은 물론, 일반 관람 자 중 신체적으로 불편감을 가지고 있는 관람자들에게 쾌적한 환경을 제공하고자 하는 노력이 반영되어있다. 실제로 포용적 박물관(Inclusive museum)을 구현하기 위한 여러 지침서 및 유니버설디자인 원칙에서도 장애인만을 위한 디자인이 아닌 모두를 위한 디자인을 추구한다는 점에서 시사하는 바가 크다. 본 가이드라인 전에 발간된 정신장애인을 위한 가이드라인을 통해서 정보와 내용적 접근성에 대한 논의 가 진행된 바가 있어, 관련한 내용을 제외하고 전시 및 동선설계 지침 가이드라인에 집중하여 차별화를 두었다.

미국 및 영국 선행자료보다 비교적 가장 최근에 발간된 지침서이며, 다양한 인체 공학적 정보는 물론 디지털 기술 적용을 통한 접근성 개선 지침을 구체적으로 다루 고 있어 박물관·미술관 등 공공부문의 기관은 물론 민간영역에서 전시 활동을 수행 하는 다양한 복합 전시공간에서의 보편적 활용이 쉬운 점이 타 가이드라인과 구분 
되는 지점이다. 전시 디자인 관련 정보로 구성되어있으나 개별 장애인의 다양한 특 수성을 반영하는 인클루시브 디자인(inclusive design) 관점이 적용되어 전시 디자 이너, 큐레이터, 등록자, 관리원, 컬렉션 관리자, 디자이너, 편집자, 개발자, 교육자 등 기관 운영자 전반에 장애인 접근성에 대한 전시 분야의 통찰력을 높일 수 있도록 하였다.

〈표 3-3〉 검토한 대표 가이드라인 내용 요약

\begin{tabular}{|c|c|c|}
\hline 검토한 가이드라인 & 세부 구성 & 시사점 및 후속 조치 \\
\hline $\begin{array}{c}\text { The Council for } \\
\text { Museums Archives } \\
\text { and Libraries(1997), } \\
\text { Disability Directory } \\
\text { for Museums and } \\
\text { Galleries }\end{array}$ & $\begin{array}{l}\text { - 총 3장으로 구성 } \\
\text { - 1장: 박물관 및 미술관에서의 장애인 접근성 } \\
\text { 과 관련한 원칙과 관련 통계, 용어, 법률에 대 } \\
\text { 한 설명 } \\
\text { - 2장: 주제별로 일반 지침과 세부 내용을 기술 } \\
\text { 함 } \\
\text { - 운영체계(institutional framework \& structures), } \\
\text { 운영정책(policies), 진단(consultation), 직 } \\
\text { 원교육(training), 접근성에 대한 진단 도구 } \\
\text { (access audits), 접견공간 및 방문자 관리 } \\
\text { (front of house \& visitor care), 마케팅 및 } \\
\text { 홍보(marketing \& publicity), 전시기법과 } \\
\text { 해석(display \& interpretation), 박물관과 } \\
\text { 포용 측면에서 교육의 역할(educational role } \\
\text { of the museum and inclusion), 자금 확보 } \\
\text { (funding) } \\
\text { - 3장에서는 참고자료와 관련한 사이트 및 연계 } \\
\text { 기관 등의 정보 }\end{array}$ & $\begin{array}{l}\text { - 문화시설에 대한 장애인 접근성 } \\
\text { 유형을 구분하고 이에 대한 기 } \\
\text { 본 원칙 및 수립 방향성을 제시 } \\
\text { 함 } \\
\text { - 후속 조치로 현장 실무자를 위 } \\
\text { 한 핸드북 형식의 장애인 서비 } \\
\text { 스 제공에 대한 안내 책자(가이 } \\
\text { 드라인) 발간하여, 실무에 필요 } \\
\text { 한 정보제공 } \\
\text { - 디렉터리형 가이드라인 및 실무 } \\
\text { 자용 안내 가이드를 기초로 한, } \\
\text { 각 항에 내용과 연계된 장애인 } \\
\text { 친화 운영을 위한 기관 자가 진 } \\
\text { 단표를 개발하여 실무 현장에서 } \\
\text { 적용할 수 있도록 함 }\end{array}$ \\
\hline $\begin{array}{c}\text { Australian } \\
\text { Museum/National } \\
\text { Museum of } \\
\text { Australia(2005), } \\
\text { Many voices making } \\
\text { choices: Museum } \\
\text { audiences with } \\
\text { disabilities }\end{array}$ & $\begin{array}{l}\text { - 총 6개 분야로 구성 } \\
\text { - 1. 서론(장애 개념과 현황) 2.접근성을 개선하 } \\
\text { 기 위해서? 3. 박물관과 미술관의 방문 과정 } \\
\text { 4. 전시 접근성 개선 5. 직원이 알아야 할 것 } \\
\text { 들 6. 주요사항과 추천 사이트 }\end{array}$ & $\begin{array}{l}\text { - 접근성의 문제를 단순히 물리적 } \\
\text { 인 접근성뿐만 아니라, 정보, 경 } \\
\text { 제적, 심리적 접근성 등으로 세 } \\
\text { 분화하여 각각의 장벽에서 발생 } \\
\text { 하는 문제에 대한 개선 방향을 } \\
\text { 제시하는 근거를 마련 } \\
\text { - 박물관 장애인 포용 실행 계획 } \\
\text { 의 근거로 활용됨 }\end{array}$ \\
\hline
\end{tabular}




\begin{tabular}{|c|c|c|}
\hline 검토한 가이드라인 & 세부 구성 & 시사점 및 후속 조치 \\
\hline $\begin{array}{c}\text { EU(2017), Report on } \\
\text { the accessibility in } \\
\text { Central Europe }\end{array}$ & $\begin{array}{l}\text { - 총 4개의 파트로 구성 } \\
\text { - 1장: EU 협력 박물관의 협의를 통해서 완성 } \\
\text { 된 접근성 지표를 통하여, 현재 상황, 접근성 } \\
\text { 개선을 위해 필요사항 체크 } \\
\text { - 2장: 유엔 협약에 따른 접근성의 다양한 측면 } \\
\text { 과 아울러 중소 박물관을 위한 서비스 체인을 } \\
\text { 포함매트릭스를 사용하여 접근성을 개선하기 } \\
\text { 위해 중소 박물관이 반드시 갖춰야 할 필수 조 } \\
\text { 건을 설명 } \\
\text { - 3장: Law Framework로 UN 장애인의 권리 } \\
\text { 에 관한 협약, 유럽 장애 전략 } 2010 ~ 2020 \\
\text { 및 관련 EU-Directives를 분석하여 CE 국가 } \\
\text { 의 비교 } \\
\text { - 4장: 타 박물관의 온라인상의 정보 및 지식 접 } \\
\text { 근성 우수 관리 기준 사례 }\end{array}$ & $\begin{array}{l}\text { - 접근성과 관련한 다양한 이슈를 } \\
\text { 매트릭스로 유형화하여 현 상황 } \\
\text { 을 진단하고 이러한 진단에 기 } \\
\text { 초한 접근성 개선의 가이드라인 } \\
\text { 을 제시 } \\
\text { - 초 국가적으로 다양한 국가의 } \\
\text { 기관의 선례 등을 공유하여, 좀 } \\
\text { 더 나은 방향으로 개선할 수 있 } \\
\text { 도록 돕는 '가이드라인'으로서 } \\
\text { 의 기능 }\end{array}$ \\
\hline $\begin{array}{c}\text { 프랑스 문화부(2017), } \\
\text { Guide Exposition et } \\
\text { parcours de visite } \\
\text { accessibles }\end{array}$ & $\begin{array}{l}\text { - 크게 } 2 \text { 개의 파트로 구성되어있으며, 세부 항 } \\
\text { 목에서는 } 7 \text { 개의 영역으로 구분하여 기술 } \\
\text { - 1장(서론)에서는 접근성의 범주와 개념, 유니 } \\
\text { 버설디자인의 원칙 } \\
\text { - 2장에서는 전시장 구성 시, 실무에서 적용되 } \\
\text { 는 요소별 가이드라인을 분야별로 구분하고 } \\
\text { 각각에 필요한 인체공학적 분석과 설계의 지 } \\
\text { 침을 설명: 전시 디자인(La scenographie } \\
\text { d'une exposition), 전시에 필요한 진열장 등 } \\
\text { (mobilier), 조명(eclairage), 그래픽과 표지 } \\
\text { 판(signaletique et graphisme), 음향(son), } \\
\text { 멀티미디어(multimedia), 전시보조기구(expots) }\end{array}$ & $\begin{array}{l}\text { - 2007년부터 발간된 문화시설 } \\
\text { 분야 가이드라인의 전시분야 가 } \\
\text { 이드라인임: 일반개론(2007), } \\
\text { 〈공연예술 분야(2009) 〈정신 } \\
\text { 장애인 수용(가능) 문화장소〉 } \\
\text { (2010) } \\
\text { - 다양한 인체공학적 정보는 물론 } \\
\text { 디지털 기술 적용을 통한 접근 } \\
\text { 성 개선 지침을 구체적으로 } \\
\text { 다룸 } \\
\text { - 실무 지침서로 활용할 수 있는 } \\
\text { 다양한 상황을 이미지로 표현하 } \\
\text { 여 정보 전달력을 높였음 }\end{array}$ \\
\hline
\end{tabular}



장애인 접근성 강화를 위한 박물관.미술관 가이드라인 수립 방향 연구

제4장

박물관·미술관에서의

장애인 접근성

현황 및 요구 분석 



\section{제1절 조사 및 분석 개요}

\section{1. 박물관·미술관 장애인 접근성 관련 운영현황 조사}

현재 국가에서 박물관·미술관의 관람객 수는 매년 조사하고 있지만(문화체육관광 부, 2019), 관람 실태와 관련하여 발간되는 통계가 없고, 개별 기관에서 관람객 만 족도 조사를 수행하는 것이 전부인 실정이다. 이에 관람객으로서의 장애인에 대한 관람 실태를 포함한 접근성 관련 내용을 통계적으로 파악하기 어렵다. 장애인 접근 성과 관련하여 장애인개발원에서 수행하고 있는 「장애인 편의시설 실태 전수조사」 에서 전시시설을 대상으로 하고 있으나, 이는 「장애인등편의법」에 해당하는 편의시 설 설치에 대한 조사로 장애인 관람 행태를 구체적으로 파악하기 쉽지 않다. 장애인 문화예술 활동과 관련하여 「장애인 문화예술 활동 실태조사」(2018)가 이뤄진 바가 있지만, 이 역시 구체적인 내용 파악하는 데는 부족하다.

이에 본 연구에서는 우선 박물관.미술관의 장애인 관련 서비스 및 운영현황에 대 한 설문 조사를 시행하였다. 모집단은 전국의 연평균 관람객 5 만 명 이상의 공립박 물관-미술관을 222개소26)를 대상으로 약 한 달간 조사하였다. 전체 모집단의 $52 \%$ 로 유효표본 115 개를 확보하여 SPSS 22.0을 활용한 빈도 및 교차분석을 하였다. 응답 기관의 특징별 비율은 다음과 같다. 전체 문화기반시설 중 박물관 및 미술관 비율에 따라 박물관과 미술관 표본을 설정하였다. 다만, 전체 표본 수가 크지 않아 지역 배분을 고려하지 않았다.27)

26) 2019년 전국문화기반시설 총람 기준 박물관-미술관의 수는 총 1,139개소(박물관 881개, 미술관 258개 소로 박물관이 압도적으로 많음) 연평균 관람객 수로 봤을 때, 5 만 명 이상의 박물관·미술관은 상위 $35 \%$ 에 해당함. 조사에 앞서 진행된 전문가 자문회의에서 전수조사를 할 수 없는 상황에서 박물관-미술관에 어느 정도의 관람객이 방문하고, 상대적으로 장애인 서비스가 쉬운 국공립 기관을 대상으로 현황을 파악 하는 것에 대하여 논의함. 또한, 박물관 수보다 수가 적은 공립미술관의 연평균 관람객 수가 5 만 이상 10 만에 다수 분포되어있는 점을 고려함

27) 박물관.미술관 장애인 서비스의 지역이라는 변수에 의하여 서비스의 종류나 성격이 차이가 있지 않아 고 려하지 않음 
〈표 4-1〉 박물관-미술관 기관 대상 장애인 서비스 현황조사 개요

\begin{tabular}{c|c}
\hline 구분 & 내용 \\
\hline 조 사 명 & 박물관/미술관 장애인 접근성 실태 현황조사 \\
\hline 조사대상 & 전국 국공립 및 사립 박물관 및 미술관 222개소 \\
\hline 조사 기간 & 2020년 6월 9일 7월 15일(총 36일) \\
\hline 조사방법 & 구조화된 설문지에 대한 응답 기관의 자가기재(이메일 및 유선 조사) \\
\hline 유효표본 & 115개 \\
\hline
\end{tabular}

〈표 4-2〉 응답 기관 특성

\begin{tabular}{|c|c|c|c|c|}
\hline \multicolumn{3}{|c|}{ 구분 } & 사례수(명) & 비중 \\
\hline \multicolumn{3}{|c|}{ 전체 } & 115 & $100.0 \%$ \\
\hline \multirow{2}{*}{ 유형 } & \multicolumn{2}{|r|}{ 박물관 } & 90 & $78.3 \%$ \\
\hline & \multicolumn{2}{|r|}{ 미술관 } & 25 & $21.7 \%$ \\
\hline \multirow{2}{*}{ 형태 } & \multicolumn{2}{|r|}{ 국립 } & 19 & $16.5 \%$ \\
\hline & \multicolumn{2}{|r|}{ 공립 } & 96 & $83.5 \%$ \\
\hline \multirow{6}{*}{$\begin{array}{l}\text { 연관람 } \\
\text { 인원 }\end{array}$} & \multirow{3}{*}{$\begin{array}{l}\text { 중소 } \\
\text { 규모 }\end{array}$} & 5만 10만 미만 & 36 & $31.3 \%$ \\
\hline & & 10만 30만 미만 & 50 & $43.5 \%$ \\
\hline & & 30만 50만 미만 & 11 & $9.6 \%$ \\
\hline & \multirow{2}{*}{ 중 } & 50만 70만 미만 & 4 & $3.5 \%$ \\
\hline & & 70만 100만 미만 & 5 & $4.3 \%$ \\
\hline & 대 & 100만 & 9 & $7.8 \%$ \\
\hline
\end{tabular}

설문은 크게 2개의 파트로 구성하여 진행하였다. 앞서 설계된 장애인 접근성 유 형을 기초로 하여 기관의 장애인 관람객 접근성 개선을 위한 활동에 대하여 운영정 책, 조사 및 연구, 직원교육, 직원 고용, 의견수렴 피드백의 5 가지 항목에 대한 총 13 개의 문항에 대한 조사를 시행하였다.

두 번째 파트로는 박물관·미술관에서 나타날 수 있는 접근의 장벽에 대한 박물 관·미술관 운영현황을 파악하고, 의견을 묻는 총 15 개의 문항을 제시하였다. 접근 의 장벽으로 제시된 내용은 감각 및 지적 접근성, 정보 접근성, 정서적/태도적 접근 성, 문화적 접근성에 대하여 조사하였다. 물리적 장벽의 경우, 앞선 파트에서 시설 및 운영현황 조사 항목에서 내용을 반영하고자 하였다. 


\section{2. 이용자 서비스 수요조사 및 분석}

이와 함께 수요자로서 장애인 및 장애인 복지관 복지사, 박물관·미술관 실무자, 장애인 편의시설 관련 전문가 총 20 명 대상으로 $1: 1$ 면담과 FGI로 장애인 서비스 요구 조사하였다. 2020년 7월 20일 9월 1일까지 총 9회 실시하였다. 대상자와 조 사 내용은 〈표 4-3〉의 내용과 같다.

실질적인 서비스의 수혜자로서 장애인의 경우 대학교 졸업 이상의 학력의 연 4회 이상 박물관·미술관 방문을 하는 여성으로 대중교통을 이용하는 개별 방문자의 관 점에서 국립중앙박물관 동반답사를 진행하였고, 다른 1 인의 경우 장애인으로서 복 지관 담당자업무를 수행하고 있어, 다른 복지관 담당자와 함께 FGI를 진행하였다.

$1: 1$ 인터뷰와 FGI는 동일하게 장애인들의 문화 활동 중 박물관·미술관 관람의 현황(방문횟수, 방문 선호 등)과 방문 여정에서의 접근 장애 여부, 개선점에 대한 제안 등을 공통으로 사전에 숙지하도록 하고 진행되었다.

〈표 4-3〉이용자 서비스 수요조사 개요

\begin{tabular}{|c|c|c|c|}
\hline 구분 & 종별 & & 비고 \\
\hline \multirow{10}{*}{ 장애인 복지관 } & \multirow{2}{*}{ 시각 } & 김OO & 제주 \\
\hline & & 황ㅇ & 경기 \\
\hline & \multirow{3}{*}{ 뇌병변 } & 김OO & 대구 \\
\hline & & 강ㅇ & 부산 \\
\hline & & 정○○ & 서울 \\
\hline & \multirow{2}{*}{ 청각 } & 0100 & 서울 \\
\hline & & 진○○ & 대전 \\
\hline & 발달 & 조○○ & 서울 \\
\hline & \multirow{2}{*}{ 종합 } & 유OO & 서울 \\
\hline & & 부○○ & 서울 \\
\hline \multirow{2}{*}{ 장애인 } & \multirow{2}{*}{ 뇌병변 } & 0100 & 1:1 인터뷰를 통한 박물관 동반 답사 \\
\hline & & 오○○ & 복지관 담당자와 함께 FGI 진행 \\
\hline \multirow{2}{*}{ 박물관 } & \multicolumn{2}{|c|}{ 최ОO } & \multirow{2}{*}{ 국공립 기관 장애인 프로그램 담당/실무자 } \\
\hline & & & \\
\hline \multirow{2}{*}{ 미술관 } & \multicolumn{2}{|c|}{ 최○○ } & \multirow{2}{*}{ 국공립 기관 장애인 및 교육프로그램 담당/실무자 } \\
\hline & \multicolumn{2}{|c|}{ 황ㅇ } & \\
\hline 장애인 프로그램 & \multicolumn{2}{|c|}{0100} & 공립박물관 시각장애인 대상 프로그램기획자/교수 \\
\hline 유니버설디자인 & \multicolumn{2}{|c|}{ 고OO } & 유니버설디자인 관련 연구자/교수 \\
\hline 장애인편의시설 & \multicolumn{2}{|c|}{ 김OO } & 복지부 산하 공공기관 장애인 업무/중간관리자 \\
\hline 장애인 특수교육 & \multicolumn{2}{|c|}{ 금○○ } & 교육부 산하 공공기관 특수교육 업무/중간관리자 \\
\hline
\end{tabular}




\section{제2절 국내 박물관·미술관 장애인 접근성 관련 운영현황}

\section{1. 기관 운영에서의 장애인 고려 여부}

조사 결과에 따르면 조사된 박물관-미술관 기관의 경우 전반적으로 장애인을 고려 한 운영정책이 별도로 수립되지 않는 것으로 나타났다. 운영의 기준이 되는 계획 수립 이나 규정 내에서 장애인을 별도로 고려하지 않는 기관이 전체 응답의 절반이 넘으며, 투입 예산이 거의 없거나 있더라도 $5 \%$ 미만으로 인 것으로 나타났다. 인력 고용에 있어도 매우 소극적이며 장애인으로부터의 의견 수렴도 거의 없는 것으로 나타났다.

\section{가. 장애인 정책 수립, 규정 여부, 예산 비율}

장애인 접근성 관련하여 운영계획을 절반 정도의 기관이 수립 경험이 없으며 (47.8\%), 관련 내부 규정을 별도로 가지고 있지 않은 것으로 나타났다. 박물관의 경우 계획 경험과 내부 규정 수립 등에 미술관보다 횔씬 소극적인 상황인 것으로 분석되었다. 입장료 관련 규정의 경우 보건복지부의 공공요금 감면 정책의 일환으 로 장애인등록증(복지카드) 제시 시 보호자 1 인을 포함한 장애인에게 요금을 감면 해주는 제도에 대한 항목으로 분석된다.

[그림 4-1] 장애인 접근성 관련 계획 수립 여부

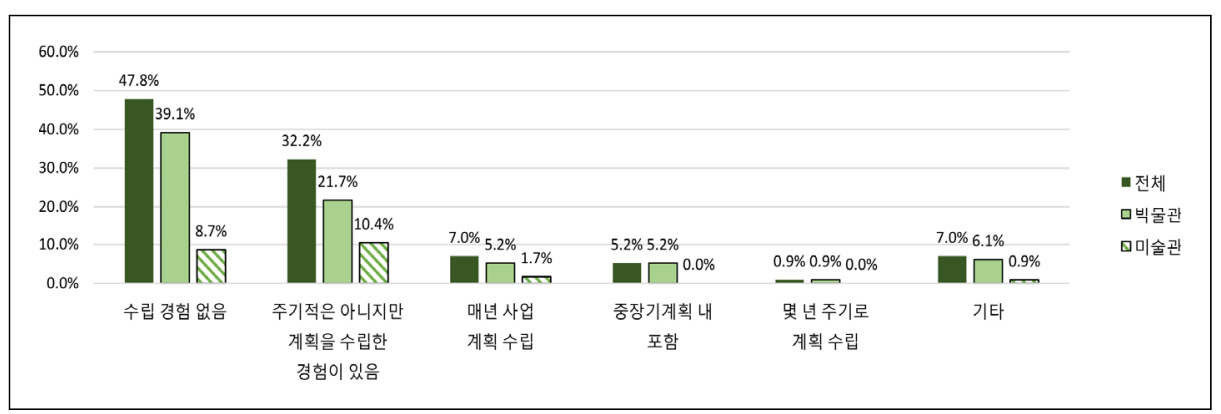


[그림 4-2] 장애인 접근성 관련 내부 규정 여부

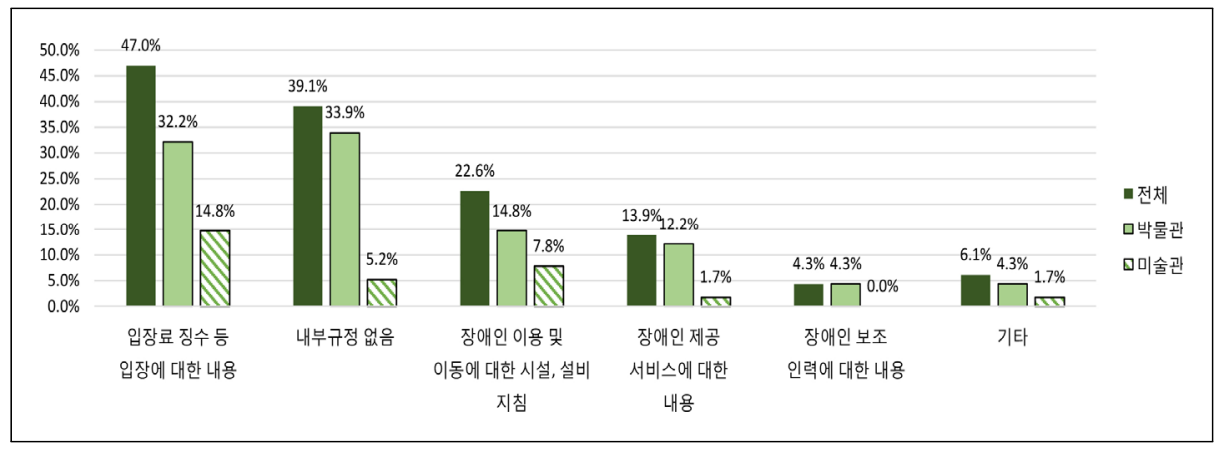

장애인 관련 예산의 경우 사업예산과 시설예산 모두 전체 운영비의 $5 \%$ 가 넘지 않는 기관이 절반 이상인 것으로 나타났다. 상대적으로 사업과 프로그램예산 보다 는 시설적 측면에 예산 투입이 좀 더 많이 이뤄지는 것으로 나타났다.

[그림 4-3] 전체운영비 대비 장애인 관련 프로그램 사업 운영예산 비율

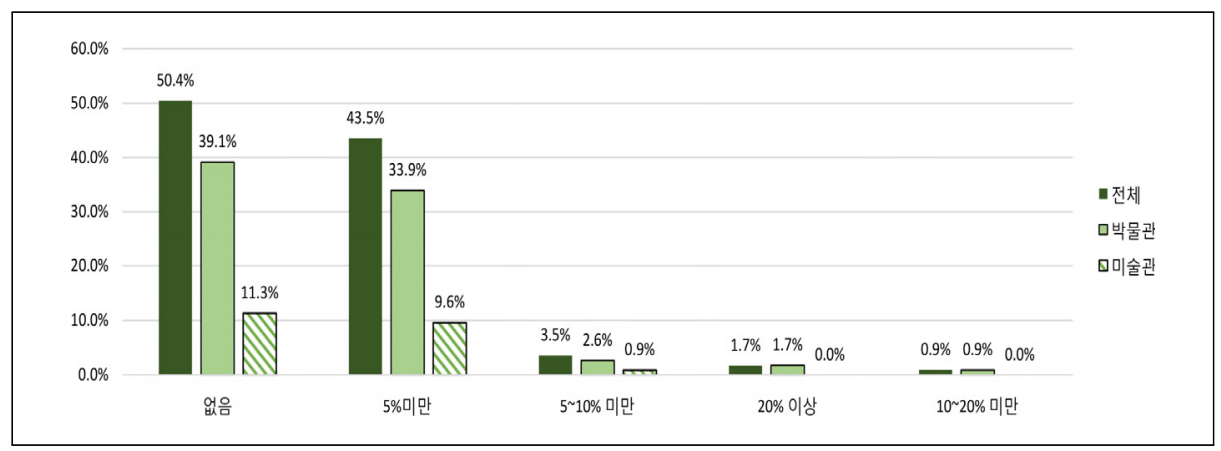

[그림 4-4] 전체 운영비 대비 장애인 '시설운영'에 소요되는 예산 비율

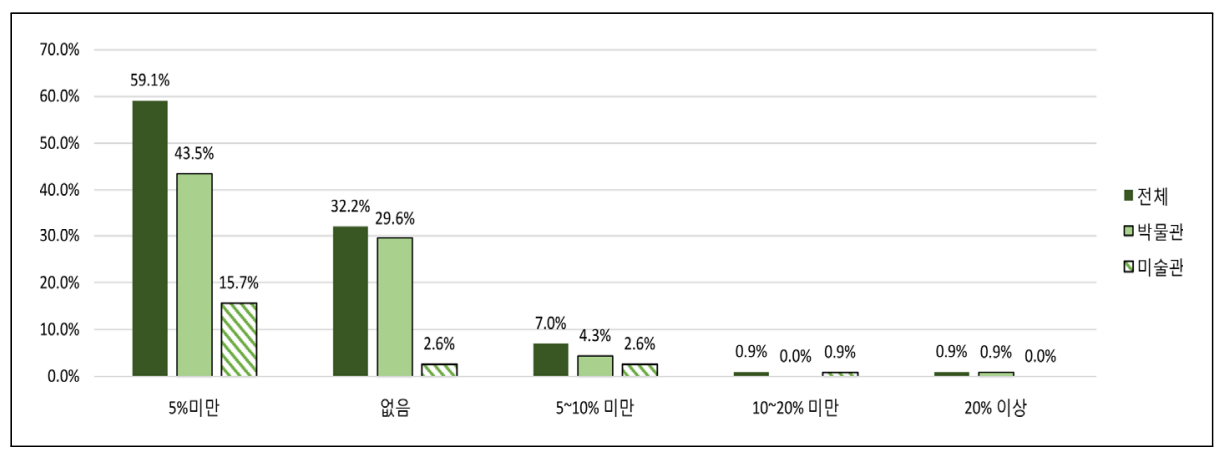




\section{나. 장애인 관련 인력과 장애인 인식 교육 여부}

장애인이 고용되어 있는 경우(35.7\%), 대부분 일반 행정 직원이고, 박물관-미술 관 주 업무를 담당하는 기획인력(학예 및 교육연구사)에는 장애인이 거의 고용되어 있지 않는 것으로 나타났다.

[그림 4-5] 중간관리자의 장애인 업무 담당여부

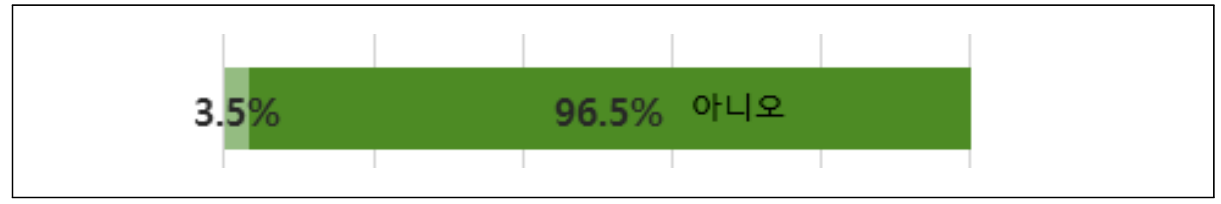

장애인 관련 업무 담당자의 직급의 경우 중간관리자급의 담당자는 거의 없는 것 으로 나타났다. 대상을 중심으로 하는 운영 정책의 경우 기관 운영의 종합적인 관점 을 지닌 중간관리자급 이상의 담당자가 총괄해야함에도 불구하고 프로그램 위주로 이뤄지는 장애인 사업에 대한 기관의 관심과 운영 비중이 높지 않을 것으로 예상되 는 항목이다.

[그림 4-6] 전문분야 지식 습득 직원 여부

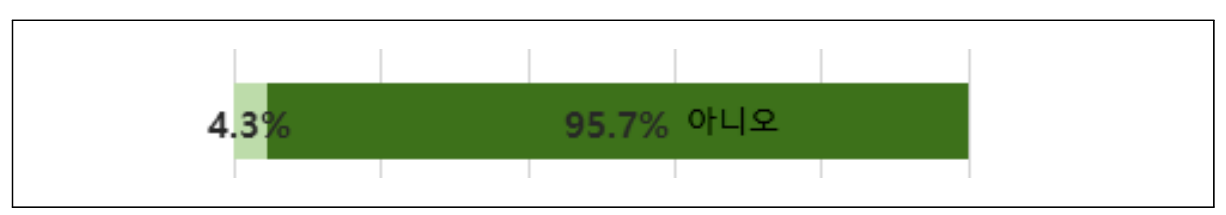

다른 한편으로는 장애인 프로그램 기획 시 관련 전문지식을 습득한 직원(학위자, 특수교육 자격증 소지자, 특수교육 프로그램 이수자) 도 거의 없는 것으로 나타났 다. 장애인의 경우 특수 교육 영역에서 다뤄져야함에도 불구하고 이에 대한 전문성 을 지닌 직원이 거의 없다는 것은 장애인 교육이 실상 전문성에 기반을 둔 기관의 특화 프로그램보다는 교육 일반 영역로서 다뤄지고 있다고 볼 수 있다.

장애인들이 기관의 내부 의사결정에 참여할 수 있는 기회 제공을 알아보기 현황 을 살펴본 결과, 기관의 직원이나 자원봉사자로 참여할 수 있도록 별도의 정보제공 은 이뤄지지 않는 것으로 나타났다. 일반 고용 현장에서 장애인은 비장애인에 비하 
여 고용이 매우 어려운 것으로 잘 알려져 있다. 장애인들에게 고용의 기회를 제공하 는 정보를 제공하는 것은 이에 대하 가장 기초적인 장치임에도 불구하고, 기관에서 별도의 정보를 제공하지 않고 있다는 점을 통하여, 이에 대한 인식이 높지 않음을 알 수 있다.

[그림 4-7] 장애인들이 직원 또는 자원봉사로 지원할 수 있는 정보제공 여부

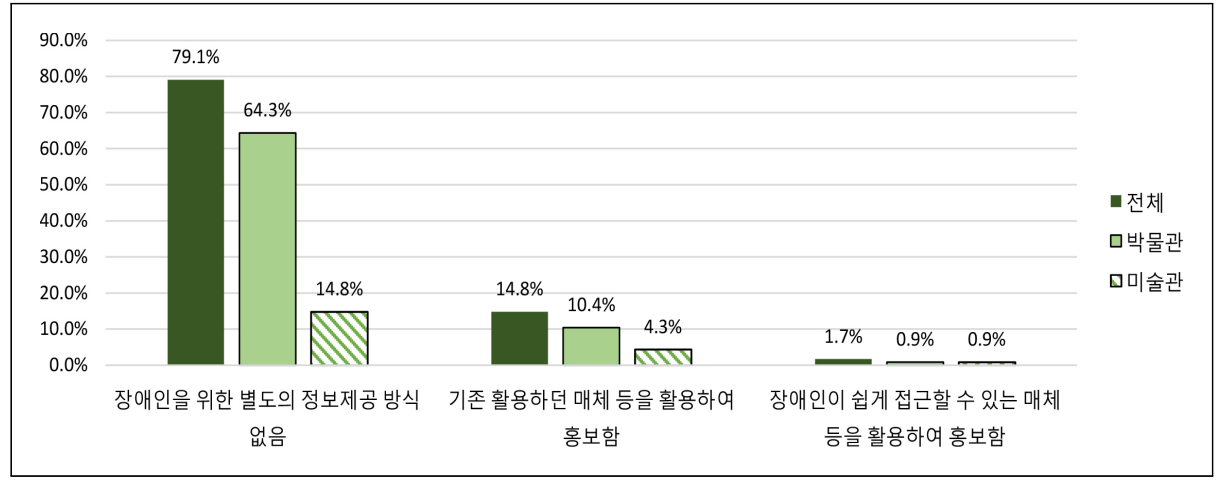

기관 내에 장애인관련 교육의 경우 의무 교육 형태로 진행되는 장애인 인식 교육 을 중심으로 이뤼지는 것으로 나타나고 있으며, 자발적인 전문 교육을 받는 직원은 많지 않은 것으로 나타났다.

[그림 4-8] 장애인응대 교육 진행 여부 및 내용

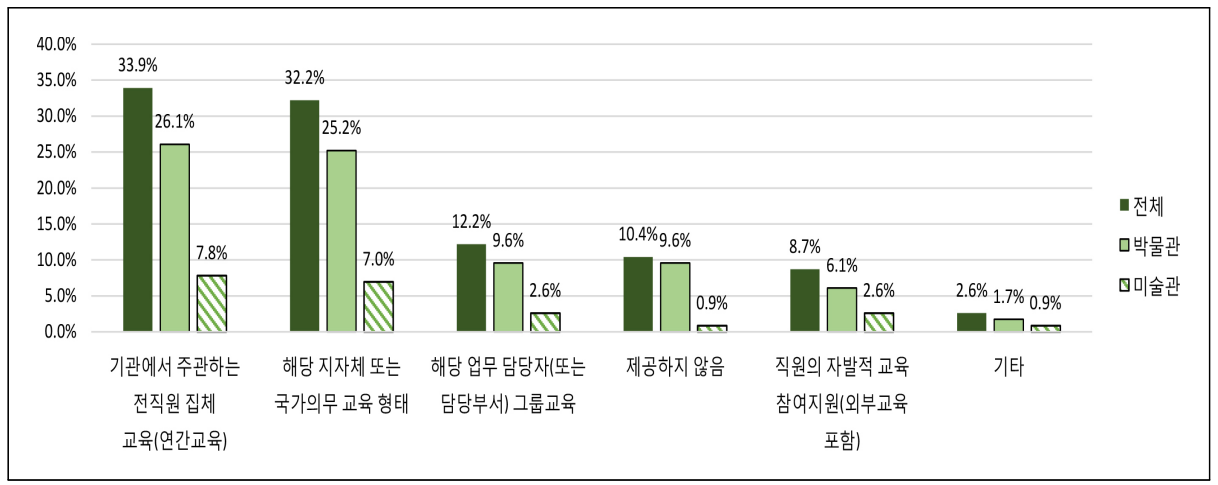

장애인 담당 직원의 경우 유니버설 디자인, 베리어프리와 같은 정보를 숙지하고 있다 는 응답이 전체 응답의 절반 정도가 되었다. 운영정책 영역에서 장애인을 거의 고려하 
고 있지 않다는 점에서, 그나마 물리적 환경에 대한 인식은 상대적으로 높은 것으로 볼 수 있다. 이는 법률적으로 장애인의 편의제공에 대한 의무 사항이 시행된 2010년대 이 후부터 꾸준히 이뤼진 제도적 효과로도 유추할 수 있다.

[그림 4-9] 담당직원의 장애인 접근성관련 정보 숙지 여부

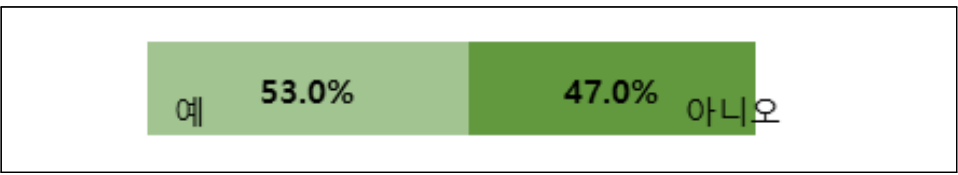

전반적으로 장애인관련 인식교육과 정보 숙지는 「장애인 등 편의법」에 고지된 수 준으로 볼 수 있고 전담하고 있는 직원의 경우 시설 운영과 관련하여 베리어 프리와 유니버설 디자인에 대한 이해가 있는 것으로 나타났다. 하지만, 전체 기관의 절반은 이마저도 숙지하지 않다는 점에서, 장애인 응대 교육 진행여부의 실효성을 다시한 번 점검할 필요가 있다.

\section{다. 장애인 의견 수렴}

관람객 의견 수렴의 대표적 방식인 만족도 조사의 경우, 장애인 이용 설문과 만족 도 조사가 별도로 이뤄지지 않다고 응답한 기관이 $65.2 \%$, 실시하는 경우에도 일반 인 조사 내 포함하고 있다고 응답했다. 장애인의 경우 비장애인에 비하여 서비스 요구 및 수요가 많이 발생될 수 있음에도 불구하고 관련한 현황을 파악할 수 있는 데이터 등이 부재할 수밖에 없는 상황임을 알 수 있다.

[그림 4-10] 자문 시 장애인전문가 포함 여부

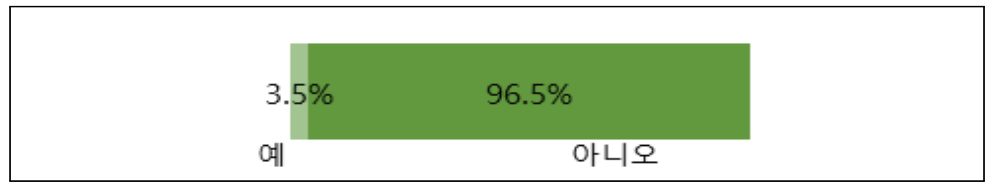

[그림 4-11] 장애인 접근성 체크리스트 구비여부

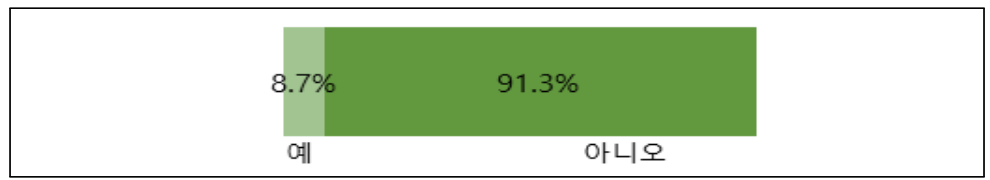


[그림 4-12] 장애인 이용 만족도 조사 시행 여부

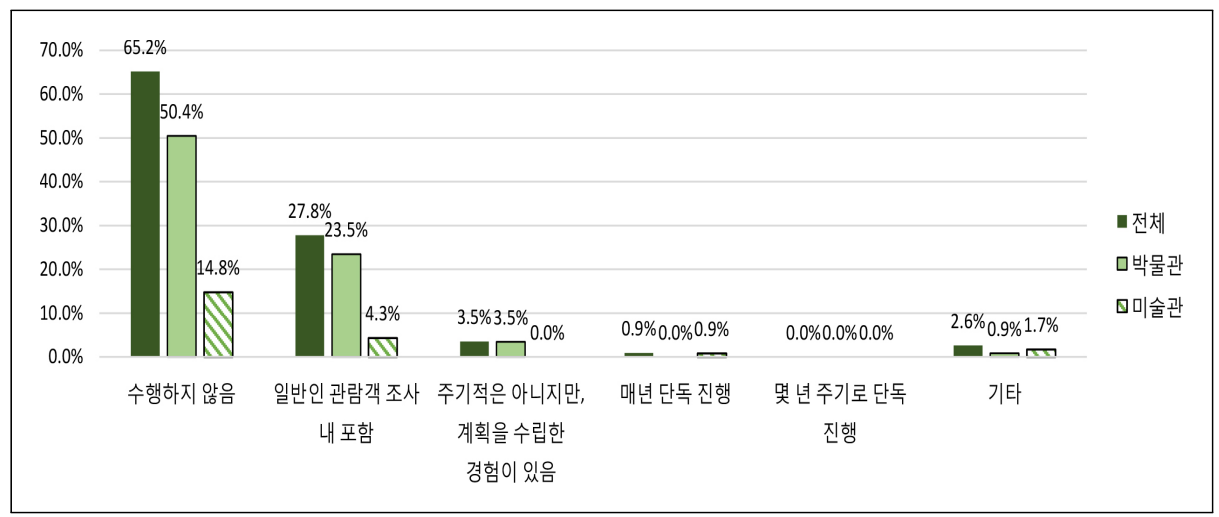

직접 이용자가 아니더라도 장애인에 대한 정책, 서비스 또는 프로그램을 기획하 기 위하여 장애인에 대한 이해가 높은 전문가를 통해서 의견을 수렴할 수 있다. 관 련하여 기관 운영 관련 자문 시 장애인 전문가를 포함 여부에 대하여 대다수의 기관 이 포함하지 않고 있다고 응답하였다.(96.5\%). 장애인 접근성에 대한 체크리스트를 구비 여부에 대해서도 대부분의 기관이 관련한 체크리스트를 가지고 있지 않다고 응답하였다.(91.3\%)

기관 내 운영정책에 내 장애인을 주요한 관람 대상 중 하나로 보는 관점이 부재된 상황에서, 관람자로서의 장애인에 대한 의견을 수렴할 수 있는 기회는 거의 없는 것으로 나타났다. 수요자 중심의 서비스를 목표로 하고 있음에도 불구하고 관련한 수요자의 의견을 듣거나 전문성을 획득하기 위한 노력이 있다고 보기 어려운 상황 이다. 장애인과 관련한 다양한 물리적 편의에 대한 법제도가 마련되었음에도 불구 하고, 관련한 제도에 대한 적절한 이행(담당 인력의 정보 숙지 여부, 예산 투입 정 도)가 이뤄지고 있다고 보기 어렵다. 


\section{2. 기관 서비스와 프로그램 운영 현황}

\section{가. 전시 안내 보조 및 안내 서비스 제공 여부}

장애인 이동을 위한 이동수단 제공 서비스(휠체어, 엘리베이터 등)가 가장 보편적 으로 제공되는 것으로 나타났으며(77.4\%) 전시 안내와 관련하여 점자 책자가 타 유 형의 장애보조용품보다 상대적으로 제공비율이 높은 것으로 조사되었다. 그러나, 영어를 제외한 다국어 리플렛이 전체의 $34.8 \%$ 정도 비치되어있는 것에 비하여 점 자책 비치가 $17.4 \%$ 로 나타나 장애인 관련 안내 서비스에 대한 관심이 높지 않은 것을 알 수 있다.

[그림 4-13] 전시 안내 보조 및 안내 서비스 제공 여부

\begin{tabular}{|c|c|c|c|c|c|}
\hline $\begin{array}{c}\text { 전시 안내 } \\
\text { 점자책자 }\end{array}$ & $\begin{array}{c}\text { 약시를 위한 } \\
\text { 큰 글씨 형태 } \\
\text { 안내 책자 }\end{array}$ & 보청 시스템 & $\begin{array}{c}\text { 영어를 제외한 } \\
\text { 다국어 리플렛 }\end{array}$ & $\begin{array}{c}\text { 근육제어가 힘든 } \\
\text { 장애인은 윅은답 하용 }(\mathrm{n}=115) \\
\text { 도구 }\end{array}$ & $\begin{array}{c}\text { 교육 체험 공간 } \\
\text { 내의 장애인 } \\
\text { 이용 가능 기구 }\end{array}$ \\
\hline $17.4 \%$ & $2.6 \%$ & $6.1 \%$ & $34.8 \%$ & $13.9 \%$ & $7.0 \%$ \\
\hline $\begin{array}{c}\text { 수화 안내 영상 } \\
\text { 서비스 }\end{array}$ & $\begin{array}{c}\text { 촉각을 활용한 } \\
\text { 전시 체험 } \\
\text { 서비스 }\end{array}$ & $\begin{array}{c}\text { 장애 유형을 } \\
\text { 고려한 전시 } \\
\text { 안내 가이드 } \\
\text { 서비스 }\end{array}$ & $\begin{array}{c}\text { 장애인 이동을 } \\
\text { 위한 이동수단 } \\
\text { 제공 서비스 }\end{array}$ & 서비스 없음 & 기타 \\
\hline $9.6 \%$ & $10.4 \%$ & $8.7 \%$ & $77.4 \%$ & $11.3 \%$ & $7.0 \%$ \\
\hline
\end{tabular}

구체적으로 리플렛이나 안내책자의 경우 장애유형을 구분하여 비치하지 못하고 있는 것으로 나타났다. 반면, 청각장애인을 위한 수화 안내 서비스를 제공 안내원의 경우, 전체 응답 기관의 절반 이상(53.9\%)가 직원으로 고용하고 있으며, 고용된 경 우 $100 \%$ 정규직으로 나타났다.

리플렛과 마찬가지로, 홈페이지에서도 장애 유형을 구분하여 별도의 서비스 페이 지를 거의 구성하고 있지 않은 것으로 나타났다(96.3\%). 홈페이지 설계시 웹 접근성 (법적 기준)을 고려하여 설계하는 경우도 전체의 $28.7 \%$ 에 불과한 것으로 나타났다. 장애인 관련 프로그램 운영 시 별도 홍보 방식 여부에 대하여(중복응답 허용) 별 도의 홍보를 하지 않는다는 응답이 $44.7 \%$ 였으며, 홍보를 하는 경우 일반프로그램 과 마찬가지로 홈페이지 등을 활용하거나(27\%), 관련기관 공문 발송(26\%) 한다는 
의견이 비슷한 비율로 나타났다. 홈페이지에 일반 프로그램과 마찬가지로 정보를 제공하고, 관련 기관과 단체에 공문을 보내는 방식으로 진행하는 것으로 분석 된다.

[그림 4-14] 장애인을 위한 별도 홈페이지 [그림 4-15] 홈페이지 설계시 웹접근성 고려여부 개설여부

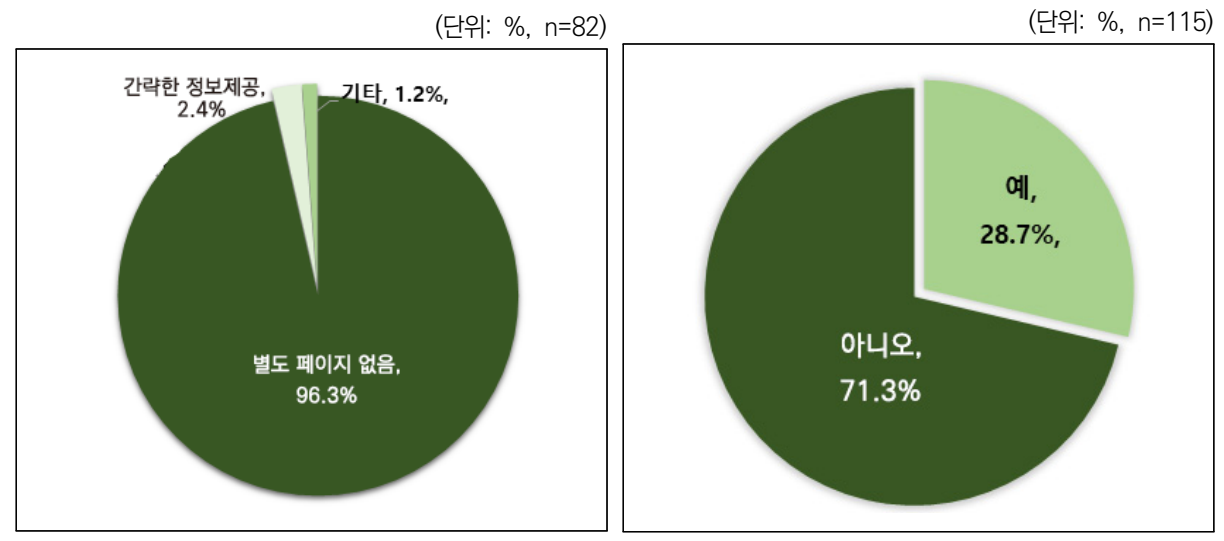

[그림 4-16] 웹 접근성 고려시 홈페이지 설계 방식

(단위: $\%, \mathrm{n}=33$ )

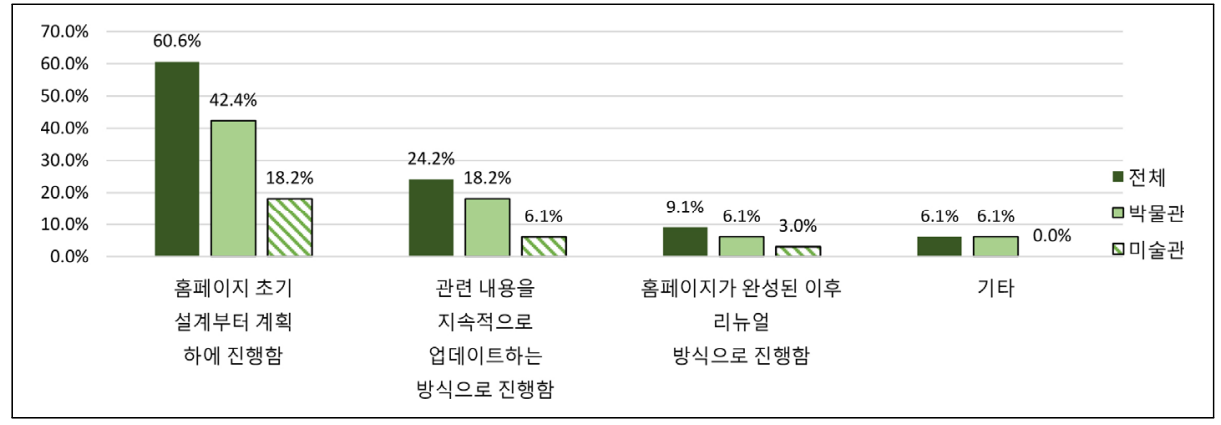

[그림 4-17] 장애인 관련 프로그램 운영 시 별도 홍보 방식 여부

(단위: $\%, \mathrm{n}=115$ )

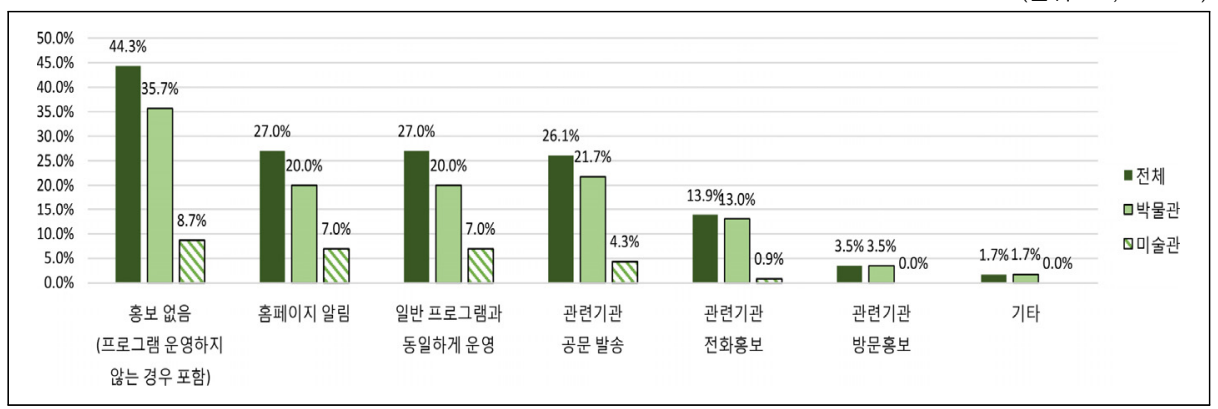




\section{나. 장애인 프로그램 운영 현황}

장애인을 대상으로 하는 프로그램을 정기적으로 운영하는 기관은 전체의 $13 \%$ 로 대부분의 기관이 정기적으로 운영하지 않는 것(87\%)으로 나타났다.

[그림 4-18] 장애인 프로그램 정기적 운영 여부

$(\mathrm{N}=115, \%)$

\section{아니오 $\mathbf{1 3 . 0 \%} \quad$ 예 $87.0 \%$}

정기적으로 운영하지 않는 경우, 전혀 운영을 하고 있지 않는 경우가 $59 \%$, 신청자 가 있을 경우 수시로 운영하는 경우가 $23 \%$ 로 나타났다. 운영하지 않는 경우에 그 이유로는 수요가 없고(36.2\%), 관련 인력이 부족하다(31\%)는 의견이 높게 나타났다.

[그림 4-19] 정기적으로 운영하지 않는 경우, 운영방식

(단위: \%, $\mathrm{n}=100$ )

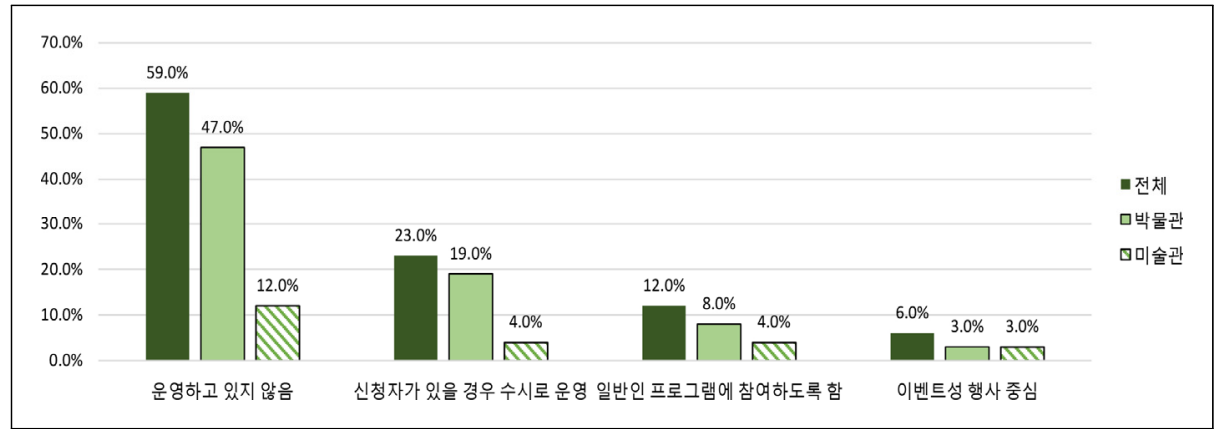

[그림 4-20] 장애인 프로그램을 운영하지 않는 이유(1순위)

(단위: $\%, \mathrm{n}=58$ )

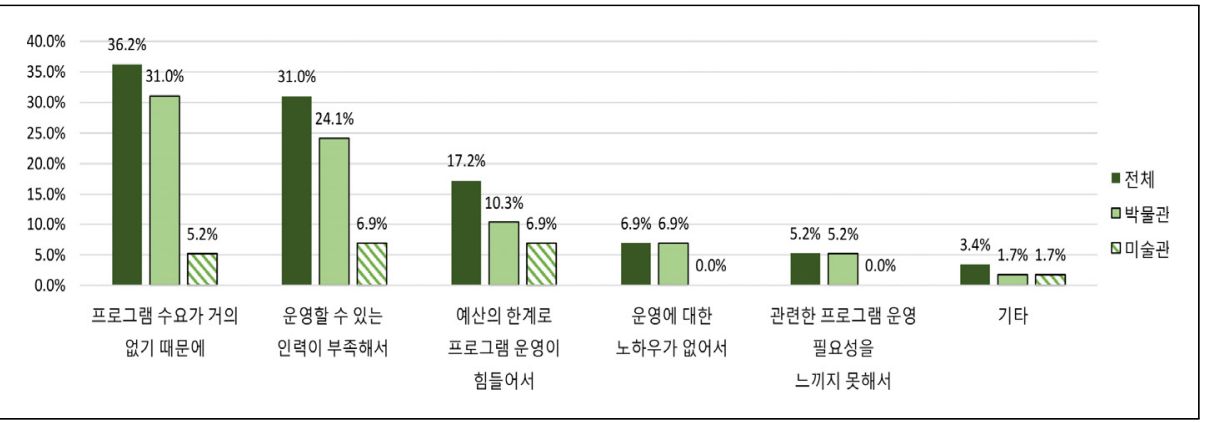


장애인 프로그램 운영은 교육 프로그램(52.7\%)을 중심으로 이뤄지고 있으며, 운 영 시 차량을 제공하는 경우가 전체 $(\mathrm{n}=55)$ 의 $45.5 \%$ 정도로 나타났다. 프로그램 운 영 시, 프로그램에 따라 교육 인원 수를 조정하는 방식(50.9\%), 10명 이상의 집체 교육으로 진행하는 경우(30.9\%)로 나타났다. 장애 유형별/연령대별로 구분하여 프 로그램이 운영되는데, 지체 장애, 발달, 청각/시각, 노인성 장애 순으로 나타났다. (중복응답 허용)

[그림 4-21] 장애인 프로그램이 주로 이뤄지는 영역

(단위: $\%, \mathrm{n}=55$ )

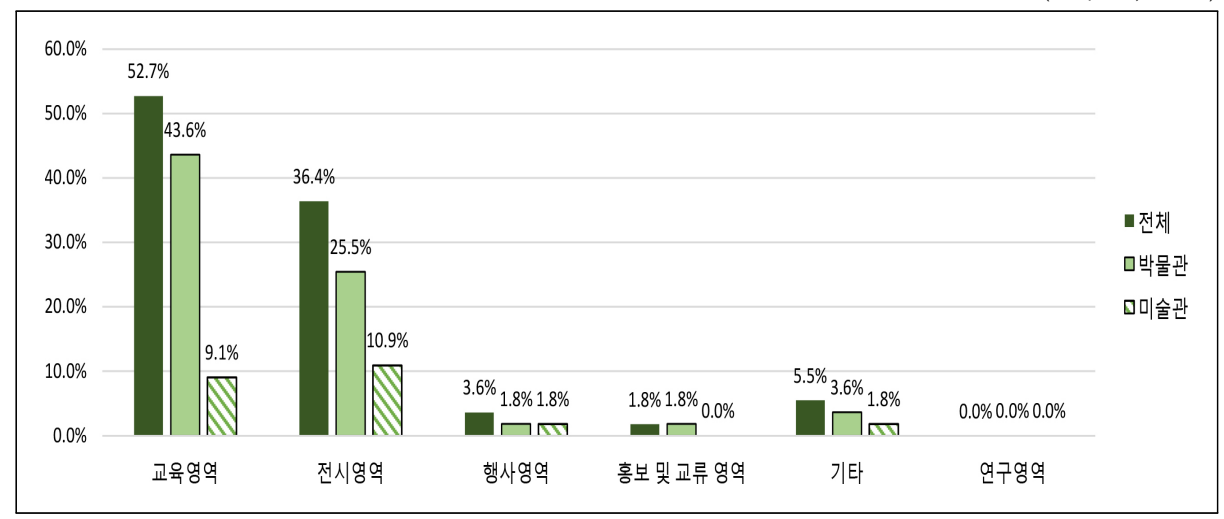

[그림 4-22] 프로그램 운영 시 고려되는 장애 특성(중복응답 허용)

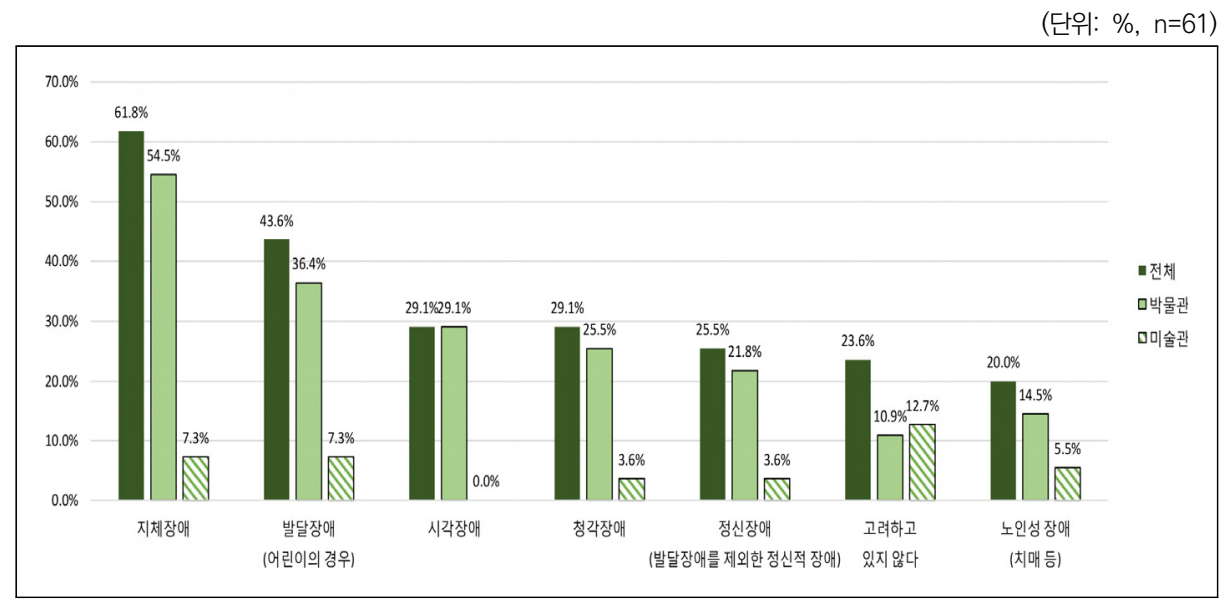


[그림 4-23] 프로그램 운영시 대상 인원 조정 방식

(단위: \%, $\mathrm{n}=55$ )

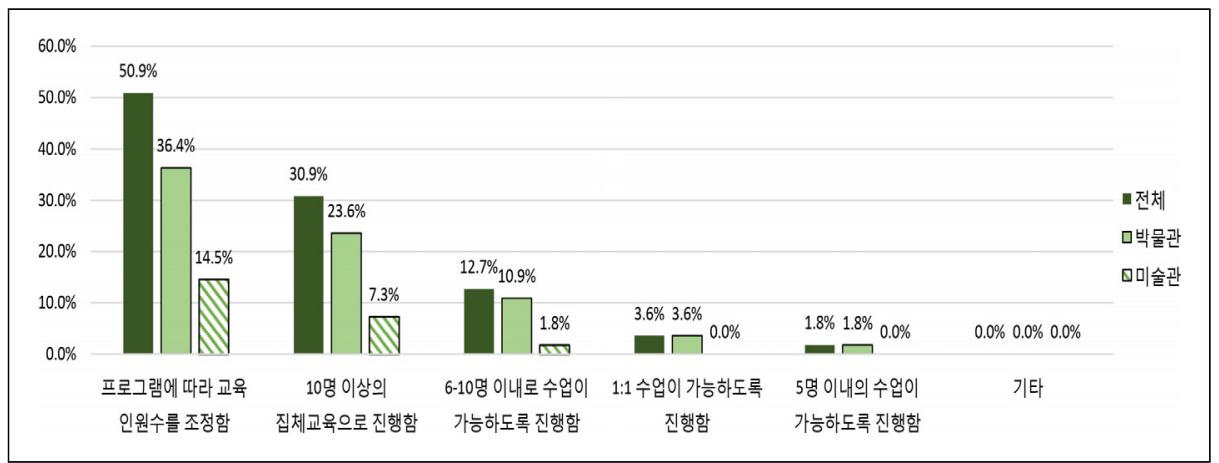

대상별로는 전 연령대를 대상으로 하는(특정 연령층 없음) 경우가 $47.3 \%$ 청소년 과 아동을 대상으로 하는 프로그램이 각 $43.6 \%, 41.8 \%$ 로 성인(32.7\%), 노인 (10.9\%)보다 많았다(중복응답 허용). 이중 실제로 활발하게 이뤄지는 대상층이 청 소년(40\%)이라는 응답이 높게 나타났다. 학생들의 경우 학교에서 단체로 이용이 가 능하기 때문에 이에 대한 공급이 상대적으로 활발하게 이뤄지는 것으로 볼 수 있다.

[그림 4-24] 장애인 프로그램 대상 연령층(해당항목 모두 체크)

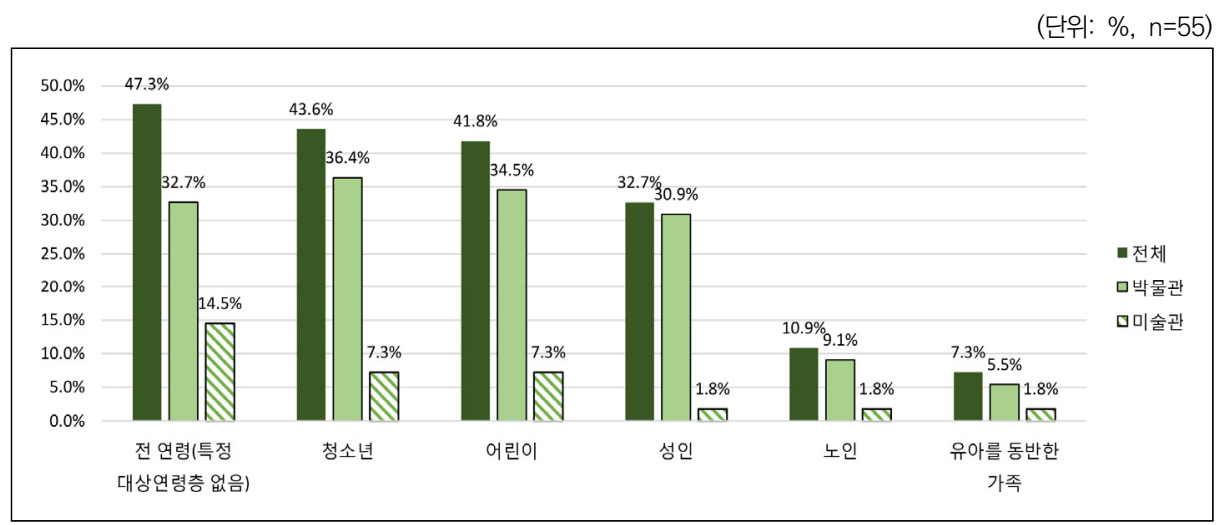

적극적인 프로그램 운영으로서 장애인을 대상으로 하는 기관에 방문하여 프로그 램을 진행하는 아웃리치 프로그램은 대부분의 기관이 운영하고 있지 않은 것 $(n=61$, $75.4 \%$ )으로 나타났다. 일부 운영하는 경우에도, 교육 기관과의 협업을 통해서 이뤄 지는 것으로 나타났다. 
[그림 4-25] 장애인 프로그램이 실제로 가장 활발히 진행되는 대상층

(단위: \%, $\mathrm{n}=55$ )

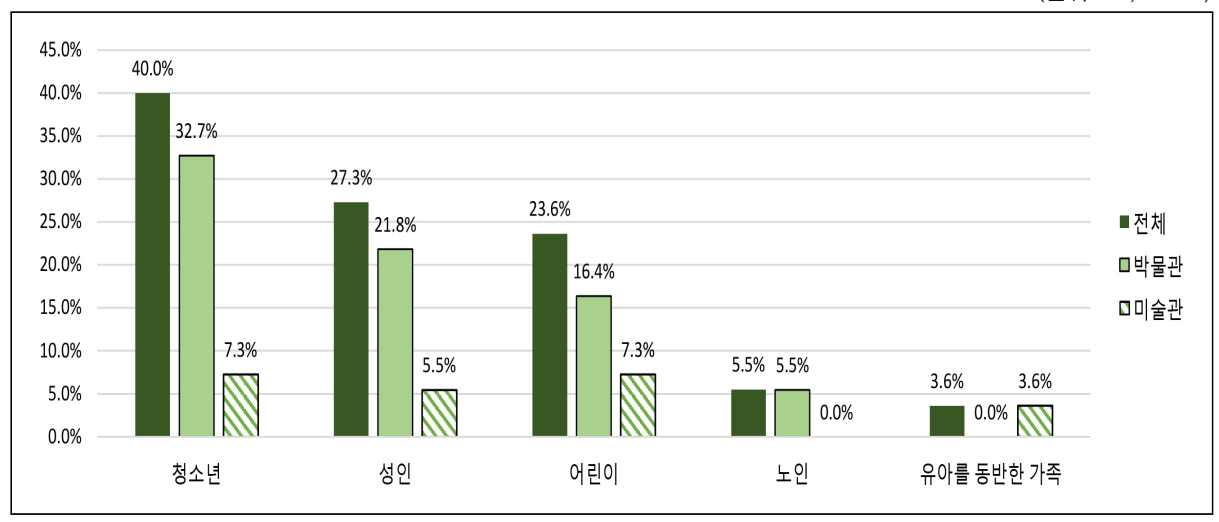

[그림 4-26] 아웃리치 프로그램 운영여부

(단위: $\%, \mathrm{n}=61$ )

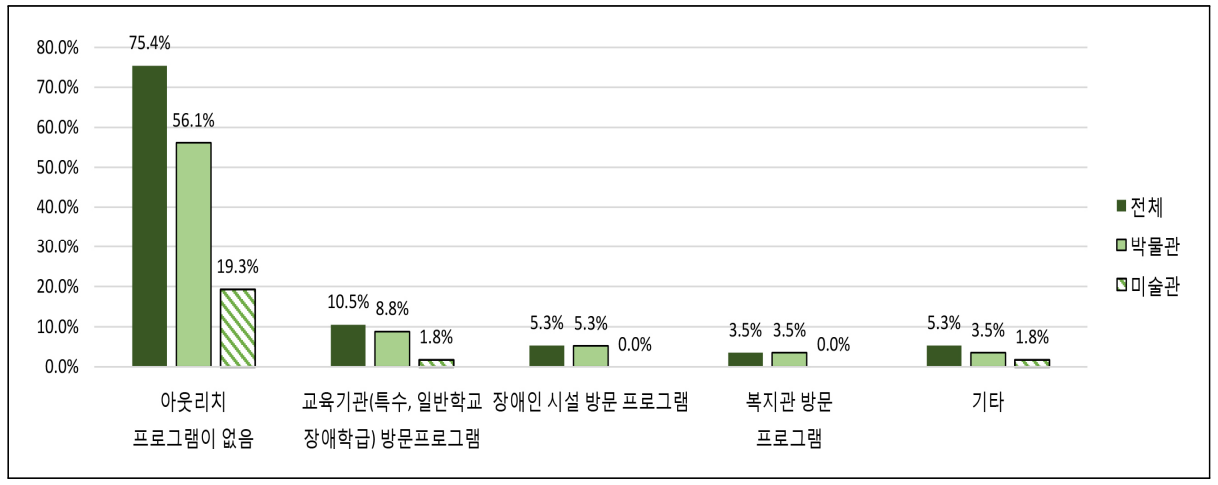

\section{3. 장애인 관련 기관 운영 방향}

장애인과 관련한 프로그램 운영 방향과 관련하여 운영하지 않는 다는 응답이 전 체 응답의 $50 \%$ 이상이었으며 운영할 경우 운영방향은 문화향유기회 확대와 소외계 층 프로그램 지원 등으로 나타났다.

전체 응답 기관의 $77.4 \%$ 가 기관 운영이 장애인 친화적이지 않다고 응답했으며, 장애인을 위한 새로운 접객 서비스 개발이 적극적으로 이뤄지고 있지 않은 것으로 나타났다(서비스 개발 없다 응답 66.1\%). 
[그림 4-27] 장애인과 관련한 프로그램 운영 시 운영 방향

(단위: \%, $\mathrm{n}=61$ )

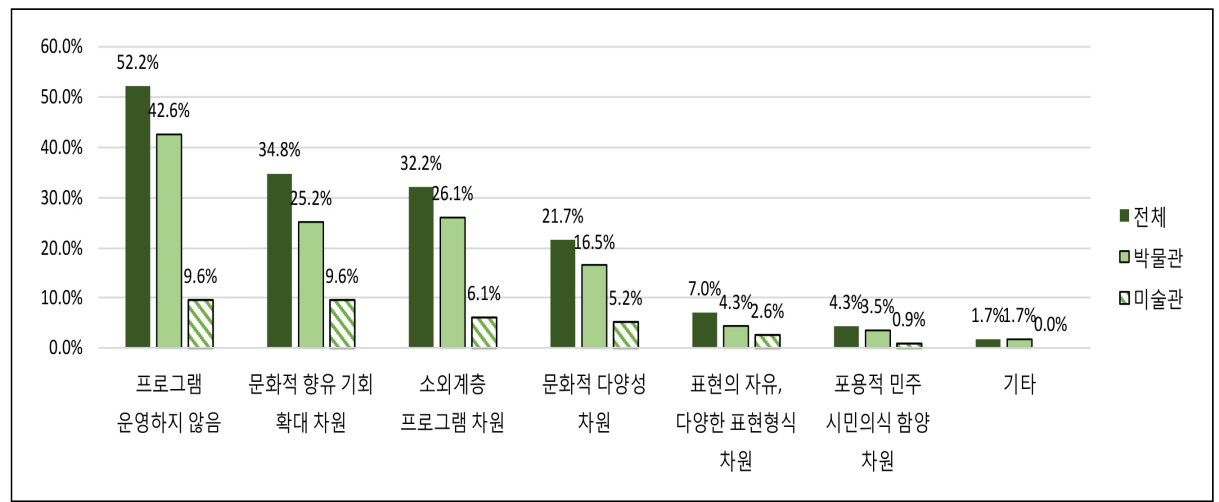

[그림 4-28] 장애인을 위한 새로운 접객 서비스 개발 여부

(단위: \%, $\mathrm{n}=61$ )

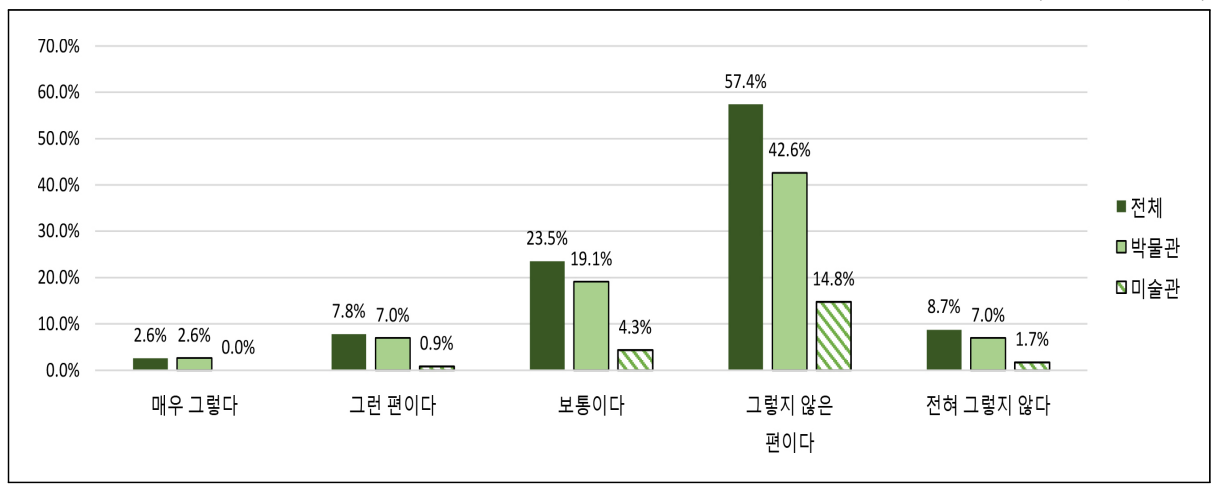

[그림 4-29] 기관 운영 시, 장애인 친화적 태도 여부

(단위: \%, $\mathrm{n}=61$ )

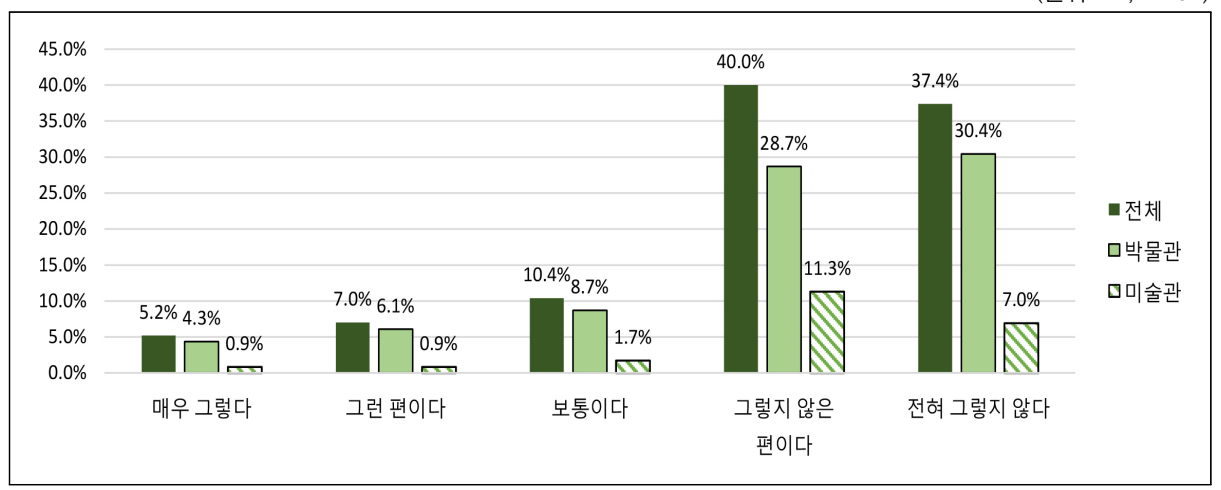




\section{제3절 박물관·미술관 장애인 접근성 관련 수요자 요구 분석}

\section{1. 박물관·미술관에서의 장애인의 물리적 접근방식과 제반 환경}

조사에 참여한 장애인 담당 복지사와 장애인 당사자가 접근성 개선의 우선 전제 사항으로 꼽은 것은 이동 편의성 확보를 포함하는 물리적 접근성 개선이다. 장애인 편의 증진법을 통하여 다수의 기관이 $\mathrm{BF}$ 인증과 같은 방식으로 최소의 편의시설을 갖추고 있는 환경이 마련되었다고 보았다. 하지만, 최소 기준을 맞춰서 설치되는 것 과 '이용 편의'를 고려한 설치 사이에 실질적 차이가 있다고 보았다. 하지만 이런 물리적 접근성은 접근성의 요소 중 '하나'로 보긴 어렵다는 것이 전반적인 의견이 다. 종합적인 차원에서 박물관·미술관 경험과의 물리적 장벽 개선과의 유기적인 연 계가 이뤄지는 것이 바로 물리적 접근성 개선의 올바른 방식으로 보았다.

\section{가. 박물관 도착에서부터 관람 이동 전반에 영향을 미치는 ‘이동 편의성'}

"(박물관을 찾지 않는 것이) 장애(를 가진 사람이 갖는) 특수성이라고 하기보다는 저희는 (일단) 어디를 간다고 하면 거기가 편의시설이 갖춰져 있는지 이걸 최우선 으로 보거든요? 경사로가 있는지 화장실이 있는지..." "복지사 A)

조사 대상자들이 빈번하게 논의한 이동 편의성은 이용자가 출발지점에서 박물관 도착까지의 과정보다는 도착 이후 정문에서부터 실내에 들어가는 과정, 그리고 실 내에서의 이동 편의성에 좀 더 초점을 두고 있다. 이는 「교통약자의 이동편의 증진 법 시행규칙」에 기초하고 있는 특별교통수단을 이용하여 상대적으로 교통수단 이용 에는 큰 어려움이 없는 상황이며, 만약 단체로 이동할 경우 박물관·미술관에서 교통 수단을 제공해줄 경우 물리적 접근성뿐만 아니라 정서적/태도적 접근성에서 더 호 
감을 느끼게 된다고 보았다.

“과천관은 장애인 단체 프로그램이 연 300명, 15회 정도인데, (접수) 오픈하자마 자, 버스까지 제공해주니깐, 한... 10분 내로 다 마감이 돼요”(연구사 $A$ )

“저희는 찾아가는 박물관이지만, 하나의 지역에 갔을 때 특수학급이나 특수 학교에 서 학생들을 모아서 하나의 장소에서 진행하는 경우가 많은데, 저희가 직접 교통수 단을 제공하기 때문에 프로그램 이용 만족도가 매우 높았어요(연구사 D)

정문에서 실내에 들어가는 과정 역시 장애인들에게는 접근 장벽이 발생할 수 있 다. 모든 건물 내에 있는 도로의 경사면, 계단 등이 장벽 중의 하나인데 이를 해결하 기 위해서 $\mathrm{BF}$ 인증을 받은 건물이 아니어도 대부분 엘리베이터를 설치하여 이동 편의를 제공하고 있다고 보았다. 하지만, 엘리베이터의 위치와 규모(수용 가능한 인 원과 크기) 등이 최소 기준을 겨우 맞추고 있는 상황에서 실질적 이용 ‘편의' 보다는 '가능'의 수준이라고 보았다. 이러한 기준을 맞추기 위해서 기존의 건물들에 대하여 규제와 권고가 필요하지만, 현실적으로 기존 건물의 동선과 구조 등을 바꾸기 어려 운 상황을 감안했을 때 새로 지어지는 박물관과 미술관에 대해서는 최소 기준을 지 키는 것을 넘어서 ‘이용자 편의성’을 고려한 설치가 반드시 실천되어야한다고 보았다.

\section{나. 종합적(holistic) 박물관·미술관 방문 경험의 전제조건 ‘물리적 접근성’}

“작품을 보러가는 것이 박물관을 방문의 주요 목적이지만, 박물관을 종합적으로 체 험하는 것이(holistic)중요 하다고 생각해요"(전문가 B)

일반적으로 박물관·미술관 방문경험은 장소 방문과 공간 경험, 그리고 콘텐츠 경 험이 종합적으로 이뤄지는 행위이다. 장애인 특성상 물리적 접근성은 개선되어야하 는 여러 접근성 중의 하나로 보기 보다는 '전제 조건' 으로서 물리적 접근성과 결합 된 다른 접근성과의 복합적인 이해가 필요하다.

“커뮤니케이션 하기 위한 reflextive experience가 필요한 것 같아요. 공간에 대 
한 접근성 뿐만아니라 요소뼐 접근으로 봐주면 되기 때문에 요소가 작품이던, 그 요소가 갖고 있는 다른 영향력이든 이런것들은 충분히 고려될 필요가 있습니다" (전문가 A)

“미술관 박물관 앞까지 가는 것은 용이해졌어요. 박물관 안에서의 내가 갈 수 있는 활동이 제한되고 아까 말씀하셨듯이. 1실 2실 쭉 가야하잖아요. 앞이 막히면 못가 고 뇌성마비 분들은 휠체어 앉으신 분들 걸음이 불편하시니깐, 우리가 막히면 뒤에 눈치도 보고. 작품에 대해서 보이스 나오죠 렌트가 안되면 글 보다가 활동지원사 분들이 읽다가 뒤에 밀리고. 위축이 되죠. 경험적으로 옛날에 이랬는데, 이번에 어떨까 라는게 은연중에 있는거에요. 유명한 전시회 있으면 가보고 싶은데, 뇌성마 비 분들은 3 5세부터 쭉 장애가 계셨기 때문에 위축이 되면 못 가게 되고......" (복지사 D)

박물관·미술관에서 물리적 장벽을 경험하게 된 장애인의 경우 박물관·미술관 경 험에 대한 정서적 또는 태도적 접근 장벽이 형성될 수 있다고 보았다. 일상적인 여 가 활동으로서 박물관·미술관 방문이 이뤄지는 일반인들과는 달리 장애인의 경우 특별한 바깥 '외출'로서 박물관-미술관 방문이 이뤄지는 경우가 많다. 하지만 이러 한 환경에서 '배제’의 경험이 각인된 장애인의 경우 박물관.미술관에 대한 관심과 흥미가 낮아질 수밖에 없다고 보았다.

프로그램 운영차원에서도 이러한 물리적 접근성 해소가 되지 않을 경우 종합적인 관람 체험을 획득하는데 어려움이 발생한다고 보았다. 예를 들어 일반적으로 발달 장애를 가진 특수교육대상 학생의 경우 다동인 특징이 있고 집중력이 동일한 연령 대 학생보다 낮을 수 있다. 이러한 학생들을 위해서는 관람 프로그램을 구성할 때 '전시관 관람-체험프로그램-관람' 과 같은 구성이 필요할 수 있는데, 대부분의 전시 관과 교육관은 분리되어 공간이 배치되어있는 경우가 많기 때문에 실질적으로 교육 의 효과를 크게 거두기 어려울 수 있다.

“단체예약을 할 때 별도의 공간이 사실은 프로그램을 만약에 한다면 별도공간이 있 어야 하잖아요. 그 프로그램을 박물관에서 마련해준 프로그램도 있지만 박물관 체 험말고 교사가 잠깐 아이들을 데리고 할 수 있잖아요. 그리고 가서 볼 수 있잖아요. 
그런 공간이 확보가 되면 좋겠다. 그래서 관람과 체험이 동시에 이뤼질 수 있는 공 간 확보가 필요하다"(연구관 $E$ )

“전시실 내에 교육시설이 없는 경우가 많다. 교육관에서 교육하고 가야하는데, 야 외, 계단, 몇 명탈 수 없는 엘리베이터를 이용해야해요. 위험천만하죠. 저는 장애 인도 장애인이지만 노인분들 교육도 하고 있는데 치매가 있으신 어르신의 경우 이 러한 이동이 십지 않은거죠"(연구사 $C$ )

"동선이 복잡하면 장애인 교육을 할 수 없어요. 대부분 전시관과 교육관이 분리되 어서 교육을 하고 전시장으로 이동하는데까지 쉽지가 않은 것이 일반적이죠. 예를 들어 국립 중에 국립고궁박물관의 경우는 교육관과 전시관이 같은 층에 놓여있어 서 장애인 교육하시는 분들의 만족도가 상당히 높아요"(연구사 $D$ )

살펴본 바와 같이 장애인의 물리적 접근성은 ‘단순히' 어떠한 물리적 장벽을 제거 해주는 것에 만족하는 수준이어서는 안된다고 보았다. 물리적 장벽을 제거하는 목 적과 방식, 그리고 그것으로 연결될 수 있는 또 다른 접근성의 문제들을 종합적으로 고려해야 한다.

\section{다. ‘모두를 위한 공간’의 관점에서 박물관·미술관 시설 및 공간 검토}

일반적인 박물관·미술관에서 관람객이 이용하는 주요 공간으로 전시 공간(상설전 시관 기획전시관), 교육 공간(교육 및 체험공간). 편의공간에서 장애인들은 일반 관 람자을 기준으로 최적화되어있다. 그렇기 때문에 장애인 방문 시, 장애인 스스로 이 용에 조심스럽게 접근할 수밖에 없다. 조사에 참여한 다수의 장애인 복지관 관게자 들은 박물관·미술관 공간이 장애인에게 '불편한' 공간일 수밖에 없다고 보았다. 하 지만 이 '불편한' 공간을 장애인들을 위한 공간으로 개선하려는 노력보다는 '모두에 게 편한 공간'으로 만드는 노력이 필요하다고 보았다.

"박물관에 진입을 하고 동선 이런 애기하는데 모든 디자인이 유니버설디자인이 되 면 모든 사람에게 편한 거잖아요. (중략) 모든 사람이 십게 접근할 수 있도록 만들 
어가는 것들이 필요한 것 같아요"(복지사 $B$ )

"장애인예술인을 대상으로 전체적으로 한번 같이 관람을 했어요. 그래서 유니버설 디자인 고쳐야할 것 하는 것을 뵀는데, 작가분들은 기관이 개관할 때부터 변화를 다 기억하시더라고요. 이들이 제안해주신 것을 리포트로 만들어서 고객지원팀으로 전달해서 개선이 되도록 했어요" (연구사 A)

“넓은 계단이 설치되는 건 좋아요. 그건 건축적으로 필요해서 만들어졌을 테니깐 요. 근데 거기에 난간을 설치하고 그 난간을 이용하게 하는 것도 중요한 것 같아요. 어디인지도 모른 후미진 곳에 놓여있는 엘리베이터를 바라는 게 아니에요. 난간이 필요한 사람이 꼭 장애인만은 아니잖아요. 그러한 눈에 보이지 않는 배려들이 아쉬 울 때가 많죠"(장애인 A)

현재 건립되어있는 박물관·미술관의 개선 만큼 중요한 것은 앞으로 만들어진 미 래의 박물관·미술관의 모습이라고 보았다. 현재 설치된 공간의 구조를 변경하는 것 은 현실적으로 예산이 많이 투입되는 공적인 영역의 일이라 개선이 빠르게 이뤄지 기 어렵다. 이에 우선적으로 규모면에서 상대적으로 큰 국립 기관의 역할이 중요하 다고 보았다. 국공립 단위의 박물관과 미술관 중 공간 규모가 중대형 이상의 기관과 입지 조건이 공원 또는 녹지공간과 연계가 되어있는 기관은 일반인보다 활동성이 중요한 장애인이 상대적으로 이용하기가 편리한 공간으로 보고 이 기관을 중심으로 장애인 프로그램 활성화를 제안하였다.

"작품 한 개를 위한 점자책 교육은 할 수 있지만 근데 그건 한계가 있죠. 그들도 와서 보고 작품을 하나 보는 게 의미가 있을까요? 미술관에 오는 것 자체가 교육이 될 수 있다고 생각해요. 가령 미술관 중에 국립현대미술관 과천관에 장애인이 많이 오는 이유는 공원에 있어서고, 경기도미술관의 경우는 미술관이 유원지 안에 있어 서 작품보고 밖에서 바람도 쐬고. 사람도 붐비지 않기 때문에 방문을 선호하는 거 라고 생각해요"(연구사 B) 
“일반인 대상 프로그램도 그렁겠지만, 특히 장애아동을 위한 프로그램은 ‘환경과의 연계"를 잘할 경우 그 효과가 극대화 된다고 생각해요"(연구사 $A$ )

"캐나다는 몬트리올 미술관이 테라피 센터를 운영을 해요. 미술관 안에 테라피 센 타가 있어요. 지역에 있는 사람들을 ‘예술’로 테라피 하는 거에요 이 사례가 흥미로 운 것 같아요. (중략) 정신적 측면까지 본다면 사실 현대인들은 다 정신적인 장애를 가지고 있다고도 애기하기도 하잖아요. 우리 모두 나이가 들면 중도 장애인이 될수 도 있구요." (연구사 B)

더 나아가 장애인들에게 박물관·미술관에서의 경험이 공간과 연계되어 치유적인 효과가 있을 수 있다고 보았다. 테라피 센터(therapy center)를 미술관에 설치한 해외의 사례(캐나다 몬트리올 미술관) 등에서도 살펴볼 수 있듯이 박물관·미술관 공 간의 역할을 단순히 ‘물리적 접근’ 환경으로만 볼 수 없다. 이러한 기능은 장애인은 물론 노화 또는 정신적인 영역에서 언젠가는 우리 모두가 언젠가 '장애'를 가질 수 있다는 점을 고려했을 때 박물관·미술관이 장기적으로 고려해볼 만한 과제가 될 수 있다고 보았다.

\section{2. 박물관·미술관에서의 장애인 서비스 접근성}

대표적인 박물관·미술관에서의 장애인 서비스 중 하나는 시각과 청각 장애에 대 하여 보조해줄 수 있는 도구를 설치 혹은 환경을 조성해주는 것이다. 이는 박물관. 미술관에서 전달하고자 하는 다양한 지식과 정보를 일반인과는 다른 방식으로 '소 통'하게 한다는 점에서 정보 전달 방식 차원에서 이해할 수 있다. 조사 대상자들은 이러한 '기본적인' 서비스조차 국내 환경에서 전반적으로 '미흡'하다고 보았다. 앞 서 살펴본 물리적 환경 개선 차원에서 최소 단위로 지켜지는 것이 시작되는 상황이 라고 평가하였다. 물리적 환경 개선은 점차 확산될 것으로 기대되나, 이러한 물리적 환경 개선이 효과를 거두기 위해서는 실질적으로 장애인이 장애 유형별로 어떠한 방식으로 지식과 정보를 습득하는 지에 대한 이해가 선행되어야한다고 보았다. 


\section{가. 장애가 있는 다양한 취향의 '관람객'으로서 정보 수집에 한계}

관람객에 대한 관심이 높아짐에 따라 다양한 관람자 맞춤형 서박물관.미술관 운 영에서 비스 제공의 노력이 활발해지고 있는 반면, 장애인에 대한 서비스는 다양하 게 이뤄지지 못하고 있는 실정이다. 장애 유형에 따른 서비스 제공은 물론이고, 다 양한 문화예술 취향을 지닌 관람자로서 개별 방문하게 될 경우 이를 고려한 환경 마련이 시급하다. 장애인의 경우 단체관람이 개별 관람보다 상대적으로 많이 이뤄 지고 있으나, 단체 관람의 경우 예약을 통한 프로그램 이용 또는 사전 전시관람 계 획 등을 조율하고 방문하게 된다. 반면 개별 방문하는 장애인의 경우 인지와 단독보 행에 문제가 없음에도 불구하고 박물관·미술관에서 제공하는 정보의 제공의 방식이 제대로 이뤄지지 않아, 관련 정보에서 소외되는 경우가 다수 발생하게 된다고 보았다.

해외의 경우 홈페이지를 통해서 장애인 방문자들이 정보를 수집할 수 있도록 장 애 유형에 따라 홈페이지를 별도로 개설하거나, 아니면 ACCESS 페이지를 통해서 방문에서부터 관람에 대한 다양한 정보를 얻을 수 있는 반면, 국내의 박물관·미술관 의 경우 이와 같은 정보 접근성에 대한 고려가 많지 않은 실정이다.

“인터넷 홈페이지에서도 사실 시각장애인들이 접근하기 쉽지 않은데 현장에 갔을 때의 정보들은 예를 들어서 리플릿으로 된 부분들도 오히려 영어나 일본어나 기본 적인 것들은 다 잘 되어 있어요. 그런데 정작 점자나 확대본이나 이런 부분은 사실 없어요. 그래서 이거는 뮌가 좀 잘못된 게 아닌가, 이것도 시각장애인의 언어인 데.." (복지사 $F)$

\section{나. '방문여정’을 고려한 종합적인 정보 제공 필요}

현 상황에서의 장애인 박물관.미술관 방문의 주요한 특징 중에 하나는 '단체' 관람 이 상대적으로 많다는 것과, 일상적인 '여가' 활동보다는 '특별한 경험' 으로서 일회 적인 방문 또는 '관광' 으로서의 인식이 높다는 점이다. 이 경우에 박물관.미술관 방 문을 준비할 때 박물관.미술관 체험의 단독 경험보다는 주변 시설의 관광일정을 함 께 고려하는 경우가 많다. 이에 방문 여정을 고려한 종합적인 정보에 제공이 중요 하다. 
“저희 복지관에서 몇 개 관광지 대상으로 점자 혁신마을 만들기 사업을 했었어요. 관광지 내에 리플렛 도록 이런것들도 점자로 별도로 만들어줄 수 있는 환경조성하 고 그것뿐만 아니라 나아가서 근처 주변에라도 음식점들 이용하게 되거든요 메뉴 판이 볼 수 있는 환경이 안되어 있어서.. 리플렛에 점자를 찍어준다던가 도록에 담 겨진 내용들을 했었던 적이 있거든요. 사실 이 사업은 실패했어요. 지속적인 협조 가 없으면 안되더라구요. 방문 영역을 확장해서 상업 시설까진 힘들지만, 박물관이 나 관광지나 이런데 만이라도 관련 정보가 확보 되어있었으면 장애인에가 꼭 누가 따라가지 않아도 혼자 가시는 분들에게 도움이 될 수 있을 거라고 생각해요” (복지사 $D)$

“코스처럼 만들어서 음식점도 $Q R$ 코드로 좀 소개도 하고 거리에서 즐길 수 있는 것들을 다 영상으로 만들어서 그것을 지도하고 그렇게 해서 좀 박물관을 재미있게 투어할 수 있는 그런 것을 이번에 진행하려고 계획하고 있습니다. "(복지사 $G$ )

\section{다. 장애인의 잔존감각 활용의 이해와 소통을 위한 보조도구 비치}

시각장애인은 기본적으로 소리와 촉각을 통하여 세상을 인지한다. 이들이 세상을 인식하는 방식에 맞는 언어 소통 방식이 박물관·미술관에서 잘 이뤼져있지 못한 실 정이다. 외국어로 된 리플렛과 마찬가지로, 시각장애인의 언어 역시 고려되어 정보 가 동일하게 제공되어야한다. 최근 스마트 기기를 활용하면 일반 관람객의 경우 정 보를 더욱 쉽게 얻을 수 있는 반면 기본적인 소통 언어가 다른 시각장애인의 경우 정보 격차가 올 수밖에 없는 실정이다.

시각 장애인의 경우, 소실된 감각이 아닌 잔존하고 있는 감각을 가지고 주변의 환경을 인식한다. 물론 이 잔존감각에 의한 정보 입력은 시각 정보 입력과 비교했을 때 정보 내용의 $70 \%$ 이상 차이가 날 수 있기 때문에 오롯이 잔존감각에 의지할 수만 은 없다. ${ }^{28)}$ 하지만 박물관·미술관에서의 프로그램은 이러한 잔존감각을 통하여 세 상을 ‘다양하게' 볼 수 있는 방식을 제시하고 시각장애인들이 사회적 경험을 습득하 는데 중요한 역할을 할 수 있다고 보았다.

28) 한국시각장애인복지관 홈페이지(2020.08.16 접속기준) 
“레벨이 있겠지만, 정보 약자들은 정보 인식 자체가 안 되잖아요, 그래서 일반적으 로 유니버설디자인 원칙 4 번을 보면 perceptable information 이란 것이 인식할 수 있는 정보라는 것이 그런 거거든요 자기가 결국 어떤 감각을 통해서 인식하지 못할 때 다른 감각으로 정보를 인식하게 하는 것 시각장애인들이 터치나 소리로 감각하게 하는 것을 말하는 거죠"(전문가 $A$ )

"시각장애인이 볼 수 없기 때문에 시각 활동을 중심으로 이뤄지는 박물관. 미술관에 서의 경험을 얻을 수 없다 것은 장애인에 대해서 가장 쉽게, 그리고 가장 많이 갖는 편견이다.(복지사 D)

“(시각장애인들은) 비장애인과 같이 동시대를 같이 호흡하기 때문에 문화와 예술에 대한 감수성이 시각장애인도 있어야만(한다고 생각합니다) 동시대에 살아가는 사 람으로서의 값어치 있는 (삶의)여건을 (마련)하고, (한 가정의) 가장으로서, 아버지 로서, 이런 역할을 하는 데(장애인의 삶에도) 예술이 도움이 될 수 있다고 생각합니 다"(복지사 E)

잔존감각을 활용할 수 있도록 하는 것의 대표적인 것은 '촉각' 전시이다. 그 외에 도 후각과 청각을 적극적으로 활용할 수 있다. '촉각'전시 모형물을 설치하는 경우 는 국내에서도 빈번하게 볼 수 있다. 하지만 전시와의 연계가 유기적으로 되어있는 지에 대한 점검이 필요하다.

“전시장 별로 유물 1개에 대한 촉각 설치물을 전시장 별로 최소 단위로 설치하는 것은 이와 같은 설명 도구가 실질적으로 어떤 효과가 있을 수 있는지에 대해서 고 민이 없이 설치된 것이라고 밖에 볼 수 없어요. 장애인을 위한 ‘구색 맞추기 식'의 설치 모형물 보다 전시를 '잘'이해할 수 있게 하는 고민이 더 많이 필요한 상황이라 고 보고 있습니다."(학예사 $C$ )

"발달장애인의 경우, 비 장애인보다 훨씬 더 십고 천천히 정보를 제공해줘야할 필 요가 있어요. 정보를 제공을 할 때 정보를 받는 사람이 어떻게 받아들이까를 고민 해야할 필요가 있듯이, 발달장애인의 경우 '좀 더 쉽게 설명해줄 수 있는' 자료가 
필요해요. 청각장애인 수화로 소통하고, 시각장애인은 점자로 하는데, 발달장애인 에게는 '십게 풀어서 쓰여진 내용'이 필요한거죠(복지사 $G$ )

\section{라. 장애인의 정보 습득을 돕는 매개자의 역할}

인지능력이 일반인보다 낮거나, 일반인과 동일한 정보 습득의 경로를 얻기 힘든 장애인의 경우 복지관 복지사와 같은 생활 속 공공 서비스 매개자들을 통하여 다양 한 정보를 습득을 하게 된다. 장애인 문화예술활동의 경우 복지관의 프로그램 또는 단체 현장 학습의 일환으로 이뤄지는 경우가 많다. 이때 장애인 사회복지사는 장애 인의 중요한 정보 전달자가 된다. 조사 대상자들은 이 전달자가 가진 정보의 양에 따라 장애인이 얻을 수 있는 정보가 달라질 수 있다고 보았다. 특히 박물관-미술관 관람의 경우, 매개자인 복지사들 역시 박물관-미술관 관람에 익숙하지 않은 경우가 많으며, 그들의 선호가 장애인 단체 활동에도 어느 정도는 영향을 미칠 수 있다는 견해가 많았다.

"사실 그런 문화적인 장르에 대해서 우리 일반 일선에 있는 사회복지사들, 십게 장 애인과 가장 접점에 있는 분들이 익숙하지 않을 수 있어요(중략) (복지사인)내가 문 화에 대해서 잘 이해했을 때 내 클라이언트 집단도 자꾸 그쪽으로 이게 정말 즐길 거리가 있고 볼거리가 있고 뮌가 거기에서 나중에 진짜 힐링포인트가 있고 그런 쪽으로 유도가 가능할 것 같아요" (복지사 F)

"아는 만큼 보이는데 사실 최측근에 있는 정보 전달자가 정보가 없기 때문에 그냥 감각적으로 십게 접근하고 피드백이 바로 바로 오는 공연문화, 이런 부분들을 더 쉽게 소개하는 거예요" (복지사 F)

매체를 통한 1 차적인 정보제공의 수준이 미약하기 때문에, 장애인들은 최측근의 정 보 전달자인 복지사에게 의존 할 수밖에 없는 상황이 발생하는 것이다. 이 때문에, 가 장 중요한 것은 장애 유형에 따른 소통방식에 '맞춰진 정보제공'이 필요하다. 동시에 매개자인 복지사들의 정보의 양을 높일 수 있는 노력 역시 함께 이뤄진다면, 박물관. 미술관을 불편한 외출 공간으로만 보지 않을 수 있는 가능성이 높아진다고 보았다. 
조사 대상자들은 또는 현장에서의 정보 전달자로서 '매개자'들의 장애에 대한 이 해와 소통 방식에 대한 습득이 중요하다고 보았다. 박물관·미술관에서 이뤼지는 정 보제공과 활동이 상대적으로 고맥락의 지식수준을 요구하는 경우가 많은데, 이를 장애인의 지적, 장애 소통 방식을 고려하여 설명해줄 수 있는 매개자들이 필요하다 고 보았다. 프로그램 강사 역시도, 단순한 체험 프로그램을 제공하는 수준에서 심화 된 내용까지 다룰 수 있는 강사가 많이 없는 상황이다. 장애인의 경우 이러한 고맥 락의 지식을 습득하는 경로가 일반인들에 비해서 매우 좁고 어렵다. 그래서 이와 같은 해설이 가능한 매개자들의 중요성이 높다고 보았다.

“박물관.미술관에서 제공하는 강좌를 듣는 것을 좋아하는데, 강좌에 가면 장애인을 거의 보기가 어려워요. 관심이 없어서 일 수도 있지만, 정보를 제공받기 어려운 것 도 원인이라고 생각합니다. 이런 지식을 경험할 수 있는 기회가 많지 않고, 익숙하 지 않게 되면 이런 분야의 정보에 무관심해 지는 것도 사실이구요"(장애인 A)

“단순한 체험 이상의 심화된 문화예술 활동에 대한 수요가 높아지고 있는 추세인 것 같습니다. 그런데 심화된 문화예술 활동을 알려주는 문화예술분야의 전문가가 많지 않아요. 복지사들이 배우는 문화예술분야, 특수교사가 배우는 문화예술 분야 는 한정적이거든요. 문화체육관광부에서 연구를 할 때 신경써야하는 부분이 이런 부분인 것 같아요"(장애인 $B$ )

\section{3. 박물관·미술관의 장애인 대상 프로그램 운영}

장애인이 박물관·미술관을 방문했을 때 공간의 편의와 함께 경험하게 되는 것은 ‘서비스' 영역이다. 서비스 영역은 장애인의 행동과 관람 특징 등을 세심하게 배려하 여 설계되어야한다. 조사 대상자들은 물리적 접근성 개선의 노력이 효과를 거두기 위해서는 이와 같은 서비스 운영에서의 질적인 개선이 중요하다고 보았다. 


\section{가. 잠재적 관람자로서 '장애인' 대상 프로그램의 상설화}

장애인은 전 국민의 $5.5 \%$ 정도밖에 되지 않은 소수이지만, 다수의 일반인들과 동일한 문화향유의 기회를 누릴 수 있도록 이에 대한 배려가 필요하다. 수요와 공급 차원에서 봤을 때, 소수의 방문가능성이 높지 않은 대상을 위한 프로그램 상설화가 효율적이지 않다고 볼 수 있다. 하지만, 박물관·미술관은 비영리 기관으로 어떠한 ‘효율성'을 기대하는 기관으로 볼 수 없다. 국민의 모두가 장벽 없이 ‘문화향유'를 할 수 있도록 대표적인 문화기반시설로서의 역할을 하기 위해서는 장애인을 위한 프로그램이 타 프로그램에 대하여 상대적으로 소외되지 않도록 상설화하고, 체계화 될 필요가 있다고 보았다.

"장애인 프로그램을 기획하고 진행하면서 장애인과 정기적인 서비스를 정부에서 보장 해줘야 해야 한다고 생각했어요. 요즘 논의되는 포용성, 공공성 이런 것의 핵 심 사업인거죠"

특히 전문 인력과 예산이 수반되어 장기적인 비전을 가지고 지속적으로 이뤼져야 하기 때문에 상대적으로 운영 환경이 열악한 공사립 박물관·미술관 보다는 국립 기 관을 중심으로 활발하게 진행되어야할 것을 제안하였다. 조직 내에서 한명의 개인 이 이를 담당하거나 하나의 부서의 프로그램으로 존속하는 것이 아닌, 어린이와 마 찬가지로 ‘장애인'을 박물관·미술관 운영의 주요 정책 대상으로 보고, 이들을 위한 서비스를 어떠한 식으로 제공할지에 대한 진지한 논의가 필요하다.

"사업 담당자가 없어지면, 사라지는 그런 사업이 아니라 반드시 시스템 내에서 지 속적으로 운영이 되는 방식으로 찾는게 중요한 것 같아요. 그걸 할 수 있는 곳은 국립 뿐이라고 생각해요"(연구사 $D$ )

이미 해외의 유수의 기관들과 마찬가지로, 기본적인 물리적 접근성과 감각적 접 근성 해소의 문제는 '고객지원'을 담당하는 부서에서 전담하고, 전시와 교육 등의 프로그램 설계 시 장애인을 포괄하는 서비스에 대한 '유니버설디자인'이 적용될 수 있도록 해야 한다. 이를 통해서 물리적 장벽 제거의 '베리어 프리'에서 종합적 차원 의 ‘유니버설디자인이 반영된’ 기관 운영이 가능할 것으로 보았다. 


\section{나. 공간에 대한 배려 뿐 만 아니라 ‘체류시간’에 대한 고려}

발달장애인의 경우 집중력의 지속시간이 일반인에 비해서 길지 않은 특징을 가지 고 있고, 다동적이다. 그렇기 때문에 주의력과 집중력을 요구하는 활동에 취약할 수 있다. 박물관.미술관은 주의력을 요하는 '시각적 체험 활동'에 최적화되어있는 장소 이기 때문에 이러한 장애인들이 이를 경험하는데 어려움을 느낄 수 있다. 이에 일반 인보다 활동이 자유로운 넓은 공간이 필요한 것 만큼 중요한 것이 장애인들만의 '시 간'을 갖게 하는 것이라고 보았다.

"예전에 박물관을 방문했던 선생넘이 이런 애기를 하더라구요. 전시 관람을 하는 인솔자가 박물관 직원 분이었는데, 발달장애 학생을 인솔해서 다니다가, 아이가 지 루해져서 바닥에 누워버린거에요. 이런 경우에 어떵게 해야하는지 난감했다는 경 험을 애기하시더라구요. 이때 필요한게 그 아이들을 잠시 관람 공간에서 벗어날 있 도록 조율하는 것인데, 그러기 위해서 일반 관람자보다 시간이 훨씬 더 들기도 하 구요, 어떤 면에선 관람 방식이 일반인과는 좀 달라야하는 거죠"(전문가 $C$ )

“요즘은 바뀌었지만 '월요일’이 박물관 휴관이던 시설에는, 장애인 프로그램을 진 행하기가 참 용이했어요. 휴관 날 장애인 프로그램을 전시장에서 자유롭게 할 수 있었거든요. 그들만의 시간과 공간이 확보되는 거죠"(연구사 D)

\section{다. 유관기관과의 방문 사전 조율, 프로그램 연계가 중요}

장애인 단체의 경우, 방문 전 박물관-미술관 관계자와 단체를 인솔하는 복지관 또는 학교의 인솔자와의 사전 조율이 반드시 이뤼져야한다. 별도의 프로그램을 설 치하는 것이 어렵고 시설 내에 장애인을 위한 편의시설 제공이 많지 않을 경우 이러 한 사전 조율과정을 통해서 보완이 가능하다고 보았다.

"인솔이 어떻게 붙어서 오는지 사전방문을 많이 하시니깐, 동선 미리 체크하고 이 동을 어떵게 하는게 안전한지 엘리베이터를 통해서 오는건 몇 명정도고, 동선을 어 떵게 나눠서 갈지, 같이 애기를 하고 전시를 볼 때 어떤 작품을 설명을 해드릴지, 
입장을 어떵게 도와드려야할지. 활동을 원할 때가 있으니 아이들 상태에 맞취서 할 수 있는게 있는지 제공이 가능하면 같이 하는거고, 그쪽에서 뵀을 때 본인들 아니 들 난이도가 어려울 것 같다 전시관람하시고 가시죠"(연구사 B)

학교의 경우, 교육과정과의 연계를 위해서 연간 스케줄 조정 등을 위한 좀 더 넓 은 범위의 사전 조율이 필요할 수도 있다. 학교의 스케줄이 연간으로 정해지기 때문 에, 이 연간 계획에 박물관·미술관 현장 체험을 포함시키기 위해서는 관련 기관 실 무자간의 연계가 중요하다.

“교육과정하고 연계하는 것이 매우 중요해요. 교육과정이라는 것은 특수교사들이 제일 잘 알아요. 현장체험학습 계획서를 써야 해요. 연간 교육과정 안에 5 월 셋째 주에 교사학습 계획안에 있어야 해요 박물관을 가야하겠다고 할 때 연계가 되어있 어야 해요. 학교는 교육과정이 법률 문서에 가까워요."(전문가 $C$ )

\section{라. 능동적이고 적극적인 방식의 정보제공과 정보의 질에 대한 고려}

학교와의 연계 프로그램 중에 효과가 높은 프로그램 중 하나는 '찾아가는 박물관. 미술관 프로그램이라고 보았다. 이동이 용이하지 않은 장애인들이 문화향유를 단 순한 '만들기 체험' 정도로 경험하는 상황에서 기관의 적극적인 아웃 리치 활동은 문화향유의 질을 높일 수 있는데 크게 기여할 수 있다.

"지역을 중심으로 약 4 년 동안 강원도, 경기도, 충청남도와 충청북도 이렁게 찾아 가는 박물관을 진행했을 때, 만족도가 상당히 높았어요. 굉장히 좋아하죠 애들이.. 당시에 기재부를 통해서 예산을 받은 것이 있었기 때문에, 한 학교를 거점으로 해 서 주변에 특수학급의 학생들을 모을 수도 있었고 프로그램 여건이 꽤 좋았기 때문 에 가능했죠."(연구사 D)

장애인은 상대적으로 정보에서 소외되기 쉽기 때문에 장애인 (사람)간의 정보 교 환이 매우 빠르게 이뤄진다. 여기서 중요한 것은 양질의 정보를 제공하는 것이다. 인터넷을 중심으로 정보의 양은 많고 장애인 역시 다양한 정보를 접할 수 있는 방식 
이 다양해지고 있다. 다만, '제대로 된' 정보를 선별하는 일은 쉽지 않기 때문에 이 러한 좋은 정보를 매개하는 방식이 중요함을 강조하였다.

“관심이 있으면 사실 접근을 하는데요, 문제는 우리가 어떤 게 진짜 정보인지를 모 르잖아요. 정말 유익한 정보인지를 이 정보를 취하는 사람 입장에서 구분하기가 어 려워요. 예를 들어서 제가 오늘 이제 이 연구원의 존재를 알았으니까 앞으로 예를 들어서 문화관광과 관련된 부분들은 이 연구원에 가서 자료를 찾아봐야지, 이렁게 있는데 사실 얼마나 많은 정보가 있습니까? 인터넷에. 정말로 정보가 넘쳐나는데 거기에서 정말 내가 알고 싶은 정보, 진짜 정보, 거기에서 이 빅데이터를 내가 알 수 있게 이거를 선별해 주는 뮌가 중간매개가 저는 있어야 될 것 같아요"(복지사 F)

“지역사회 기반으로 탑다운이 아니고 밑에서 올라가야하는 (문화예술은 특히) 아웃 리치 활동들 우리가 모르는 아웃리치 활동등이 상당히 많을 거같은데 지역사회 기 반의 예술활동 단체들이 찾아가는 봉사활동 많이 할깨에요. (중략) 장애인들은 정 보가 약하기 때문에 이런 리소스 즉, 어디랑 연계해야하는 지가 중요한 것 같아요 "(전문가 $C$ )

\section{마. 특수교육대상학생의 체험학습 기회 마련과 단계별 맞춤 교육 제공}

조사 대상자들은 학령기의 유·초등학생, 청소년들은 성인 장애인 보다 상대적으 로 박물관·미술관에 빈번하게 방문하는 그룹으로 보았다. 특수교육대상자로서 장애 인 특수학교 또는 일반학교의 특수학급의 현장학습 등의 기회를 통해서 방문하게 되는 경우가 많다. 하지만, 일반 학생들과는 달리 인지 능력이 높지 않아, 학습 위주 가 아닌 놀이를 통한 체험의 제공과 특수성을 고려한 교육 설계가 필요하다(국립한 글박물관, 2018: 60).

“특수교육대상 학생 중 시각 청각은 점점 줄어들고 있어요. 의학이 발달되다보니 보완적인 것이 많이 나오고 청각장애는 인공와우 수술을 해서 청각장애도 많이 줄 고 있고. 지금은 장애인식도 많이 개선되고 있죠. 그래서, 전체 특수교육대상 학생 중 55\% 이상은 발달장애라고 보면 됩니다(중략) 지적능력은 낮은데, 성장발육은 
같아요. 발달장애아이들 같은 경우, 1 차적 욕구, 성적욕구는 비슷하다고 봐야하는 거죠. 인지능력에 사회적 능력이 결함되니, 함께 생활하는게 쉽지 않은거죠. (중략) 일반 학생들과 학습 목표는 동일해요, 다만, 이젓을 이해시키는 방식이 횔씬 쉽게 이해될 수 있는 방식으로 고민해야하는 거죠."(전문가 $C$ )

일반인과 마찬가지로 장애인의 경우도 박물관.미술관에서의 단계별 교육의 필요 성이 제기되었다. 장애인 교육을 하나의 유형으로 구분하는 것이 아닌, 장애유형에 맞는 단계별 맞춤 콘텐츠를 개발할 필요가 있다고 보았다.

“국립고궁박물관 장애인 교육 프로그램은 장애 유형별로 적용이 되는 콘텐츠가 아 예 달라요. 2008년부터 시작했고 고궁박물관이 선도적으로 했었죠. 2014년부터는 박물관은 방문하기 힘든 학생들을 위해서 찾아가는 박물관을 한거죠. 겅기도 강원 도, 충청남도 충청북도까지 하고. 멈칬죠(중략) 만족도가 높았고, 유형별로 프로그 램 선택지가 많기 때문에 장애학생들의 참여가 매우 적극적이었어요" (연구사 D)

특수학교(또는 특수학급) 에서도 문화예술분야의 경우 일반학생과 공통 교육으로 이수되는 과정이기 때문에 이러한 것을 고려하여 기관에서도 장기적으로는 통합적 교육프로그램으로서 장애와 비장애를 구분 짓지 않고, 모두가 함께 할 수 있는 열린 교육에 대한 준비가 필요함을 강조했다.

"특수학급에서 주지교과(국어, 수학, 영어) 어려운 것들은 특수학급에서 수업을 받 고 자기수준에 맞도록 음악미술체육은 일반아이들과 무난하게 섞일 수 있도록 같 이 받는거에요. 중·고등학교 마찬가지구요"(전문가 $C$ )

“국립현대미술관은 문화나눔이라는 컨셉으로 장애인 프로그램을 했고, 이후에 접 근성 개선 차원으로 장애인을 다맀어요. 과천관은 학급 단체 중심 서울관은 장애 가 족 중심(중락) 유형을 별도로 구분하진 않고 있지만 기본적으로 일반학생과의 통합 교육을 지향하고 있고 이를 목표로 프로그램을 설계하고자 하고 있어요" (연구사 A) 


\section{4. 문화접근성을 높이기 위한 노력 '모두를 위한 박물관·미술관'}

장애인 접근성 강화는 결국 ‘포용적' 박물관을 향한 시작점일 수 있다는 의견이 다수를 이루었다. 장애인을 대상화하고 구분하는 것이 목적이 아니지만, 현 시점의 국내 상황을 고려했을 때 장애인을 위한 배려의 영역이 의무화 되어 차별을 해소하 고, 접근성을 개선할 필요가 있다고 보았다. 장애 감수성 함양을 위해 기관과 부처 의 협력 노력 등이 반드시 함께 이뤄져야한다고 보았다.

\section{가. '장애 감수성' 함양: 장애인이 아닌, 문화향유를 하는 사람으로서 존중}

장애를 가진 사람이지만, 박물관.미술관을 방문하는 목적과 이유는 일반인과 같 다. 스스로 문화와 예술에 대한 관심이 높아서 방문을 하기도 하지만, 누군가에 이 끌려 단체관람을 통해 생애 첫 경험을 얻을 수도 있다. 이와 같은 시각에서 출발한 다면, 장애인에 대하여 우선적으로 고려되어야하는 것은 장애에 대한 배려 여부보 다 '어떻게 관람 만족도를 높일지'가 될 수 있다. 관람 만족도를 높이는 방식을 여러 가지가 있을 수 있다. 편의성을 제고하고, 맞춤형 프로그램을 제공하고, 다양한 문 화적 욕구를 충족시킬 수 있는 서비스를 개발하는 등 박물관.미술관에서 이미 적극 적으로 하고 있는 일들을 '장애인'을 위해서도 하면 된다고 보았다.

"지금은 종합적인 측면에서 방문 경험의 퀄리티를 높이는 것이 중요하고 필요하다, 문화적 접근성을 수준을 높여야하는 시점이 되었다."(전문가 B)

장애인을 '위한' 무언가를 해야하는 것을 고민하는 것보다, 먼저 '누구나 방문할 수 있을 것'이라는 전제에서 서비스를 고민하면 '누구나'의 범위 안에 장애인도 반 드시 포함이 되어야 한다. 박물관.미술관 운영자들, 특히 서비스를 전담하는 현장의 최전선의 실무자들이 인권에 대한 감수성을 지니는 것은 언젠가 방문하게 되는 '누 군가'를 위한 문화적 서비스 제공의 기본 조건이다. 
"내가 박물관. 미술관 어디를 가면 직원들이 바라보는 시선이 2가지에요 '너무 과도 하게 친절하거나' '과도하게 불친절하거나' ...그냥 문화를 즐기는 것을 좋아하는 다 같은 사람인데, 약간의 배려가 좀 필요할 뿐인데 말이죠"(장애인 A)

\section{나. 문화민주주의 정책 실현의 기조 하에 국립기관의 역할 중요}

장애인을 위한 배려는 프로그램의 '양적 확대'에서 출발 하는 것이 아닌 질적 제 고에서부터 출발한다고 보았다. 현재의 박물관·미술관 운영 상황(인력과 예산 등)에 서 장애인 대상 프로그램을 '늘려라'라는 방식의 양적 확대는 오히려 운영 현장에서 의 역효과를 불러일으킬 수 있다고 보았고, 수요-공급 차원의 단순 논리에 기대어 활성화되기 어려울 수 있다. 장애인에 대한 기관의 운영 정책은 수요-공급이 아닌 '문화적 접근성 개선'과 '문화 민주주의'의 비전하에 추진되는 ‘모두를 위한 박물관. 미술관'의 일환이 되어야 한다.

"전 이 사업을 담당하면서 반드시. 국립에서 이 역할을 담당해야한다고 보았어요. 국립이 이런 역할을 하지 않으면 누가 하겠어요? 국립기관이 가진 공공성의 실현을 무엇으로 보는지 고민하지 말고 장애인 대상 프로그램부터 출발하면 된다고 생각 해요"(연구사 D)

“제가 장애인 프로그램을 시작할 때는 소외 계층 대상 프로그램이었던 것을 문화접 근성을 있는 것을 업그레이드 했는데, 접근성이라던지, 기본권 차원에서의 문화의 향유 평준화를 고려해야한다고 생각했어요. 문화권(리) 차원에서의 모두를 위한 것 차원에서 가는 거지 활용이라는 단어라든지, 관람객 개발 차원이 우선이 아니라고 봐요. 박물관미술관이 열렸다고는 하지만 더 열려야하고 더 낮춰야하고 장벽을 낮 추는 차원 접근성을 개선하는 차원인거죠(중략) 포용적 차원 풀이를 해야 해요. 그 런게 이뤄지면 효과 중에 하나가 다양한 관람객이 늘어난다는 거지 관람객 개발을 위해서 이런 것을 해야한다는 차원은 아니라는 거죠"(연구사 A) 


\section{다. 기간 간, 범 부처 간 협력이 중요}

'대상' 중심의 정책이 추진될 때 가장 중요한 것은 대상과 관련된 부처와 관련 기관들의 협력이라고 보았다. 현 상황에서 우리나라에서 '장애인'에 대한 주업무를 담당하는 부처는 '복지부’와 '교육부' 이지만 국민의 문화에 대한 모든 업무를 총괄 하는 문화체육관광부 역시 장애인에 대한 '문화예술분야' 의 주 업무를 담당하는 부 처로서 역할을 수행해야한다고 보았다.

"범부처의 연계가 중요하다는거. 몇 번을 강조해도 지나치지 않은 것 같아요. 이런 정책연구에서 지속적으로 애기를 해줘야 아까 이 연구를 토대로 해서 향후 정책 연구를 할 때, 범부처 연계가 필요하다는 점을 인식 라는거에요. 복지부는 복지부 애기만하고 교육부는 교육부 애기만 하고. 그래서는 안되고 장애인을 대상으로 하 는 정책은 범부처간 연계가 중요해요" (전문가 $C$ )

\section{라. 지역에서의 미술관 접근 장벽 해소 노력 필요}

박물관.미술관 방문을 나눠봤을 때, 박물관에 방문하는 것이 훨씬 빈번히 이뤄지고 있다고 보았다. 박물관은 미술관에 비하여 상대적으로 방문할 수 있는 곳이 많고, 미술관은 광역을 중심으로 설치된 중대형 공간 외에 사립에서 운영하는 공간은 중 소형 규모가 많기 때문에 장애인이 방문하기에 적합하지 않다는 요인도 작용한다.

"박물관 방문도 많지 않지만, 미술관은. 정말 더 많이 안가는 거 같아요. 일단 미술 관을 어렵게 생각하는 것 같아요. 편하게 즐기고 온다는 생각을 했을 때 먼저 떠오 르는 곳은 아닌거죠" (장애인 A)

"저희 같은 특수 복지관도 광역단위에 설치되어있어서 주변에 거주하시는 분들만 이용할 수밖에 없는 한계가 있어요. 물론 멀리서도 오시긴 하지만. 내 생활권 내에 이용할 수 있는 문화시설이 있는 것이 중요한데, 미술관을 박물관보다 많이 경험할 수 있는 것 같지 않아요"(복지사 A) 
반면 미술관에서 '경험'할 수 있는 것들이 장애인의 다양한 역량을 높이는데 효과 적일 수 있다는 의견도 있었다. 방문하기는 힘들지만 한번 방문을 하고 프로그램을 경험할 경우 '미술관 경험'은 장애인의 다양한 문화적 욕구를 높이는데 도움이 된다 고 보았다.

“미술관은 예술적 표현이 중요한 공간이죠. 미술관은 해석의 영역, 이야기들이 확 장되어 나갈 수 있기 때문에 표현이 가능한데, 박물관은 분석의 공간이에요, 전시 품에 대해서 보수적인 태도가 있어요. 사람걱정이 아니라 유물걱정을 많이 한다고 볼 수도 있죠. "(연구사 $C$ )

"장애 가족 프로그램을 진행했을 때 만족도가 상당히 높았어요. 예술이 가진 '치유 적' 관점을 적용해서 프로그램을 했는데, 장애아동을 지닌 가족들의 스트레스도 높 다고 많이 애기하잖아요. 장애아동을 위한 프로그램뿐만 아니라, 예술을 통해서 가 족들이 함께 이러한 부분을 해소할 수도 있는 것 같아요"(연구사 A) 


\section{제4절 소결}

\section{ㅁ 박물관·미술관 장애인 접근환경: 준비되지 않은 환경과 인식 부족}

조사결과에 따르면 장애인 관련 박물관·미술관 운영 여건은 전반적으로 매우 열 악한 상황으로 타나는 것을 알 수 있다. 장애인관련 복지 및 교육에 법제도가 정비 되고 다양한 정책과 사업이 추진되고 있는 상황이지만, 문화여가활동 차원에서 박 물관·미술관에서의 장애인 이용 환경은 매우 열악한 실정이다.

박물관.미술관의 중장기 계획 또는 정책적 차원에서 반복적으로 언급되는 '국민 의 문화향유 확대를 위한 노력'을 생각한다면, 조사 대상 박물관.미술관의 상황으로 봤을 때 근본적으로 이에 대한 제고가 필요한 상황이다. 박물관-미술관의 서비스 공급 차원에서 봤을 때 장애인을 위한 서비스 제공을 제대로 하고 있다고 보기 어려 우며, 이를 추진할 정책 도구(예산, 조직, 인력, 정책 등)도 갖춰져 있지 않은 상황이 다. 장애인의 경우 일반인과 달리 '물리적 여건'이 어느 정도 갖춰진 환경에 대하여 방문이 가능하다. 이에 일반 관람객과 같은 '수요'에 기반한 운영이 아니라 '서비스 공급'이 우선이 되어야한다. 조사 응답 중 장애인 프로그램 운영하지 않는 이유 중 '수요가 없기 때문'에 대한 응답이 높게 나타난 것은 이에 대한 박물관.미술관 운영 자의 인식이 높지 않음을 반증한다.

\section{망애인 접근성 범위: ‘편의 제공’에서부터 ‘전시 관람 및 프로그램 이용 환경 마련’까지}

조사에서도 드러난바와 같이, 현재 장애인 관련한 최소한의 법적 기준도 맞추기 어려운 상황이다. 장애인에 대한 다양한 편의제공에 대한 박물관-미술관 차원의 노 력이 촉구된다. 편의 제공은 장애인에게는 정보 습득보다 우선되는 사항이 될 수 있다. 관람 여정 차원에서 봤을 때 정보의 습득의 용이성, 이동의 편의성은 박물관. 미술관 방문의 시점이다. 이러한 정보습득이 홈페이지를 통해서 가장 빈번하게 이 
뤄진다고 한다면, 조사 대상 기관을 찾는 장애인들은 박물관-미술관으로부터 정보 를 얻을 수 없는 구조이다.

「장애인등편의법」에서 규정하는 것은 최소단위의 설치 기준으로 편의제공을 위해 서 갖춰야할 요건들이다. 설치를 통해서 편의가 '제대로' 제공되기 위해서는 그 안에 있는 다양한 서비스 요소들에 대하여 장애인을 중심으로 다시한번 검토되어야 한다. 박물관·미술관의 장애인관련 사업의 경우 프로그램 중심으로 이뤄지는 것으로 알 려져 있다. 반면 조사결과에 따르면, 이러한 장애인 대상 프로그램 운영 조차 활성 화되었다고 보기 어려운 것으로 나타났다. 장애인 프로그램을 정기적으로 운영하지 않는 경우가 전체의 $59 \%$ 로 나타났다. 정기로 운영하지 않는 이유는 수요가 많지 않기 때문이라는 응답이 가장 높게 나타났다. 이는 박물관·미술관이 비영리 기관으 로서 수요-공급의 관점에서 운영되지 않음에도 불구하고, 장애인 프로그램 또는 사 업 추진을 수요-공급의 관점에서 보고 있다는 점에서 모순적이며 장애인 접근성에 대한 박물관·미술관의 공공성 실현의 문제를 재검토해야 할 대목이다.

공급측면에서 장애인 프로그램 자체에 대한 운영이 많지 않고, 엘리베이터, 휠체 어 등 법정 최소 설치 시설로서 장애인 이동수단 외에는 안내 서비스조차 제대로 갖춰져 있지 않은 상황이며 연계하여 장애인 서비스와 프로그램 운영이 전반적으로 열악한 상황이다. 프로그램 운영 시에 청소년과 아동을 중심으로 학령기 대상의 프 로그램이 상대적으로 활성화되어있으며, 운영 시 이동 수단 제공 맞춤형 인원 조정 등으로 진행되고 있는 상황이다. 특히 박물관·미술관은 문화적 활동을 수행하는 전 문 기관이자 방문하는 이들에게 문화를 향유하는 공간이다. 장애인들이 박물관.미 술관을 방문했을 때, 문화를 향유할 수 있도록 여건을 마련해야한다. 전문 기관이 하는 역할을 장애인이 제대로 이해할 수 있도록 박물관·미술관의 전시와 교육 프로 그램이 장애인들이 이용하기 편한지까지를 생각해봐야 한다.

\section{대상에 대한 이해: 집합적 의미의 '장애인'이 아닌 독립적 개인의 '장애인' 관람자 고려}

요구 분석 결과에서 공통된 의견 중 하나는 '장애인은 으하다'라고 말하지 않아 야 한다는 것이다. 장애인이라도 다 같은 장애인이 아니며, 같은 장애가 있다고 다 같은 취향을 갖는 것은 아니다. 박물관.미술관에서 비정기적으로 운영하는 장애인 프 
로그램은 '개별 관람객'을 위한 것이 아닌 장애인 단체 예약을 위한 비율로 봐야한다. 개별 관람객이 방문하기 위해서는 상시로 전시 공간에서의 편의제공 시설이 있어야하 며, 늘 안내받을 수 있어야 한다. 하지만, 현재 여건으로는 여간 어려운 일이 아님을 요구 분석을 통해서 살펴볼 수 있었다. 요구분석 참가자들은 일반 관람객과 마찬가지 로 박물관-미술관에 장애인이 개인적으로 혼자 방문할 수도 있고, 친구와 혹은 가족 과 방문할 수 있다는 점을 우선적으로 고려할 때 박물관.미술관의 장애인 서비스는 많은 것이 달라질 수 있고 보았다. 그들이 가진 각기 다른 유형의 장애 뿐만아니라 그들이 가진 취향까지 고려할 수 있도록 장애인 서비스가 설계되어야 한다.

\section{ㅁㅡㅡ로그램의 세분화: 장애인 생애 주기를 고려한 프로그램 운영 마련}

맞춤형 서비스와 프로그램 설계에서 장애 유형과 함께 고려되어야하는 부분은 장 애인의 생애주기이다. 특수교육대상으로 여겨지는 학령기의 아동과 청소년에 집중 되어있는 프로그램 뿐만 아니라, 고령화로 인하여 장애가 발생하게 되는 중장년층 에 이르기 까지 다양한 계층을 대상으로 하는 프로그램이 박물관.미술관 별로 포진 되면, 장애인들이 자신의 장애에 배려가 잘되는 복지관을 찾아가듯이 자신에 맞춰 진 프로그램이 있는 박물관-미술관을 찾게 될 수 있다. 학령기의 학생 단체의 경우 에도 학습 뿐만아니라 문화예술, 인문분야의 다양한 지식을 습득하고 진로를 탐색 할 수 있는 문화 활동 공간으로서 프로그램을 설계할 필요가 있다고 보았다.

\section{ㅁ 환경조성: 장애인을 배제하지 않는 장애인 친화 경영 여건 마련}

기관 대상 조사에서도 나타난 것과 같이 조사대상 박물관-미술관의 현재는 장애 인을 고려하지 않고, 친화적이지도 않은 상황이라고 할 수 있다. 요구 분석에서 나 타난 내용들을 반영하기 위해 가장 중요한 것 중에 하나는 박물관·미술관 경영에서 의 포용성 강화와 장애인 친화에 대한 인식이다. 이러한 인식을 바탕으로 정책을 수행할 수 있는 예산, 인력 등의 지원이 이뤄져야 '제대로' 정책과 사업이 운영될 수 있다. 이를 위해서 필요한 사항들을 가이드라인에 담고 그것을 실천할 수 있는 구체적 방안들을 모색할 수 있어야 한다. 
〈표 4-4〉 장애인 접근성 유형별 도출된 현황 조사 및 요구 분석 결과 종합

\begin{tabular}{|c|c|c|c|}
\hline \multicolumn{2}{|c|}{ 접근성 유형 } & \multirow{2}{*}{ 조사된 박물관-미술관 현황 } & \multirow{2}{*}{ 서비스 요구 사항 } \\
\hline 대분류 & 세분류 & & \\
\hline \multirow{3}{*}{$\begin{array}{l}\text { 물리적 } \\
\text { 접근성 }\end{array}$} & 이동 편의성 & $\begin{array}{l}\text { - 제공되는 서비스 중 이동 수단 } \\
\text { 제공이 높음(77.4\%) }\end{array}$ & $\begin{array}{l}\text { - 유니버설디자인 고려한 시설 점검 필요 } \\
\text { - 대중교통 도착과 건물입구까지 이동편의 종합 } \\
\text { 적인 제고 필요 } \\
\text { - 전반적 안내판 설치에서 장애인 눈높이 고려 } \\
\text { - 휠체어 이용자의 눈높이 등 고려 필요 }\end{array}$ \\
\hline & 감각적 접근성 & $\begin{array}{l}\text { - 장애 유형별 보조장비의 설치 } \\
\text { 비율이 높지 않음(가장 높은 } \\
\text { 것이 점자책자 } 17.4 \% \text { 이나, 다 } \\
\text { 국어리플렛 } 34.8 \% \text { 보다 낮음) }\end{array}$ & $\begin{array}{l}\text { - 장애인 유형별 보조 안내자료 비치 } \\
\text { - 유형별 안내 보조원 또는 전시 설명자 } \\
\text { (도슨트) 배치 희망 }\end{array}$ \\
\hline & 웹 접근성 & $\begin{array}{l}\text { - 장애인을 위한 별도 홈페이지 } \\
\text { 가 설치되지 않음(96.3\%) }\end{array}$ & $\begin{array}{l}\text { - 장애 유형별 홈페이지 제작 필요 } \\
\text { - 웹접근성 고려한 홈페이지 및 온라인 콘텐츠 } \\
\text { 설계 필요 }\end{array}$ \\
\hline \multirow{3}{*}{$\begin{array}{l}\text { 서비스 } \\
\text { 접근성 }\end{array}$} & 태도적 접근성 & $\begin{array}{l}\text { - 담당직원의 접근성 관련 숙지 } \\
\text { 여부(53\%) } \\
\text { - 전체 운영 사업비의 거의 없거 } \\
\text { 나 } 5 \% \text { 가 안됨(93.5\%) }\end{array}$ & $\begin{array}{l}\text { - 직원 장애인에 대한 응대 방식 교육필요 } \\
\text { - 장애인의 이동속도 및 다양한 상황에 대한 } \\
\text { 배려 필요 } \\
\text { - 직원들의 필요서비스에 대한 숙지 필요 }\end{array}$ \\
\hline & 경제적 접근성 & $\begin{array}{l}\text { - 내부 규정 내 입장료 징수(무료 } \\
\text { 입장) 관련 항목이 있음(47\%) }\end{array}$ & $\begin{array}{l}\text { - 무료관람 입장이지만, 기획 전시나 비용이 높 } \\
\text { 은 유료 전시의 할인율이 높다고 보기 어려움 }\end{array}$ \\
\hline & 웹 접근성 & $\begin{array}{l}\text { - 홍보가 별도로 이뤄지지 않음 } \\
\text { (44.3\%) } \\
\text { - 웹접근성을 고려하지 않음 } \\
\text { (71.3\%) }\end{array}$ & $\begin{array}{l}\text { - 박물관여정에 대한 종합적 정보페이지 필요 } \\
\text { - 박물관 주변시설(음식점 등)에 대한 정보 제 } \\
\text { 공 필요 }\end{array}$ \\
\hline \multirow{3}{*}{$\begin{array}{l}\text { 프로그램 } \\
\text { 접근성 }\end{array}$} & 지적 접근성 & $\begin{array}{l}\text { - 장애인 프로그램 기획 직원이 전 } \\
\text { 문분야 습득하지 않음(95.7\%) } \\
\text { - 전연령 대상의 일반 프로그램 } \\
\text { 이 다수(47.3\%)이며 청소년이 } \\
\text { 나 어린이 중심 프로그램 운영 }\end{array}$ & $\begin{array}{l}\text { - 장애 유형 및 인지에 따른 단계별 교육 필요 } \\
\text { - 쉽고 단순한 내용으로의 정보 전달 필요 } \\
\text { - 생애 주기별 접근 필요 } \\
\text { - 통합교육 차원의 접근 } \\
\text { - 온라인 콘텐츠 등에 대한 소개 이상의 적극적 } \\
\text { 참여가능한 프로그램 필요 } \\
\text { - 매개자(복지사, 보조인 등) 교육을 통하여 문 } \\
\text { 화예술 체험 기회 확대 노력 필요 }\end{array}$ \\
\hline & 정서적 접근성 & $\begin{array}{l}\text { - 장애인 프로그램이 정기적으로 } \\
\text { 이뤄지 않음(87\%) }\end{array}$ & $\begin{array}{l}\text { - 체험교육을 통한 기간에 대한 친밀감 제고 } \\
\text { - 지역에서의 미술관 경험/미술 체험에 대한 } \\
\text { 기회 확대 필요 }\end{array}$ \\
\hline & $\begin{array}{l}\text { 의사결정에 } \\
\text { 대한 접근 }\end{array}$ & $\begin{array}{l}\text { - 장애인 만족도조사가 별도로 } \\
\text { 이뤄지지 않음 }(65.2 \%) \\
\text { - 장애인 전문가 자문을 받지 } \\
\text { 않음(96.5\%) } \\
\text { - 장애인 직원이나 자원봉사 결 } \\
\text { 도 모집 창구가 없음(79.1\%) }\end{array}$ & $\begin{array}{l}\text { - 서비스 설계에 장애인의견 수렴 } \\
\text { - 장애인 예술 활동의 결과 또는 장애예술인 } \\
\text { 작품 전시의 기회 제공 필요 } \\
\text { - 장애인 인식개선 관련 테마 주제 기획필요 }\end{array}$ \\
\hline
\end{tabular}




\begin{tabular}{|c|c|c|c|}
\hline \multicolumn{2}{|c|}{ 접근성 유형 } & \multirow{2}{*}{ 조사된 박물관·미술관 현황 } & \multirow{2}{*}{ 서비스 요구 사항 } \\
\hline 대분류 & 세분류 & & \\
\hline \multirow[b]{2}{*}{$\begin{array}{l}\text { 문화적 } \\
\text { 접근성 }\end{array}$} & 정서적 접근성 & $\begin{array}{l}\text { - 아웃리치 프로그램이 운영되지 } \\
\text { 않음(75.4\%) }\end{array}$ & $\begin{array}{l}\text { - 장애인 문화여가 활동 공간으로 활용 } \\
\text { - 직원 및 운영 전반 장애 감수성 고려 } \\
\text { - 아웃리치 프로그램 및 학교연계 활성화 }\end{array}$ \\
\hline & $\begin{array}{l}\text { 의사결정에 } \\
\text { 대한 접근 }\end{array}$ & $\begin{array}{l}\text { - 장애인 프로그램을 관리하는 } \\
\text { 중간관리자 없음(96.5\%) } \\
\text { - 장애인 접근성 관련 계획 수립 } \\
\text { 이 없음(47.8\%) } \\
\text { - 장애인 친화적이지 않음 } \\
\text { (77.4\%) }\end{array}$ & $\begin{array}{l}\text { - 장애인 고용 활성화 } \\
\text { - 복지관-박물관 직원간 의견 교류를 통한 } \\
\text { 장벽완화 노력 } \\
\text { - 부처간 노력을 통한 장애인 중심 서비스 개선 } \\
\text { 노력 필요 }\end{array}$ \\
\hline
\end{tabular}



장애인 접근성 강화를 위한 박물관.미술관 가이드라인 수립 방향 연구

제5장

\section{장애인 접근성 강화를 위한 \\ 가이드라인 수립 방향}





\section{제1절 가이드라인의 구성 및 기본 원칙}

도출된 이슈와 현황 조사의 결과를 2장에서 구분한 장애인 접근성의 유형에 따라 재분류하고 이를 종합하여 가이드라인의 기본 원칙과 수립 방향을 다음과 같이 제 안하고자 한다.

기본 원칙과 가이드라인 수립 방향으로 구성하였다. 기본 원칙에서는 장애인 접 근성 강화에 대한 종합적 방향성을 제시하고 세부 방향에서 영역별 가이드라인 세 부적인 내용을 다룬다. 분야별로 원칙을 중심으로 제시하되 차후 구체적 가이드라 인 도출을 위한 참고자료로 국내외 관련 가이드라인 및 프로그램 운영 사례를 제시 하고자 한다.

기본 원칙은 장애인 문화활동으로서 박물관·미술관에서의 활동이 갖는 의미를 장 애의 사회적 모델과 인클루시브/유니버설디자인, 그리고 박물관·미술관의 사회적 책무의 차원에서 다음의 3가지로 제시하고 〈표 5-1〉에서 보는 바와 같이 접근성 유형에 따라 4 개의 가이드라인 수립 방향을 제시하였다.

박물관·미술관에서만 제공할 수 있는 서비스를 전문화하거나 관련 서비스를 좀 더 제대로 제공하기 위한 목적을 두고 있어 시설 지침과 서비스 지침이 분리된다고 보기 어렵다. 이에 국내의 박물관·미술관의 장애인 접근성 강화를 목적으로 한 가이 드라인의 경우 박물관·미술관의 전문공간에서 필요한 설치물들에 대한 시설 가이드 라인과 서비스 가이드라인을 종합적으로 바라보는 관점에서 수립될 필요가 있다. 또한, 수립을 위한 방향성을 제시를 위해 세부적인 시설 지침보다 앞서 기본 원칙과 방향을 정리할 필요가 있다. 이에 본 연구에서는 박물관·미술관에서의 장애인 접근 과 관련한 기본 원칙을 담은 영국 The Council for Museums Archives and Libraries(1997), 호주 Australian Museum/National Museum of Australia(2005) 의 구성을 참조하여 기술하였으며, 세부 구성 요소의 경우 상기의 참고 가이드라인 을 요소를 인용하여 제시하였다. 
〈표 5-1〉 장애인 접근성 강화를 위한 박물관-미술관 가이드라인의 구성

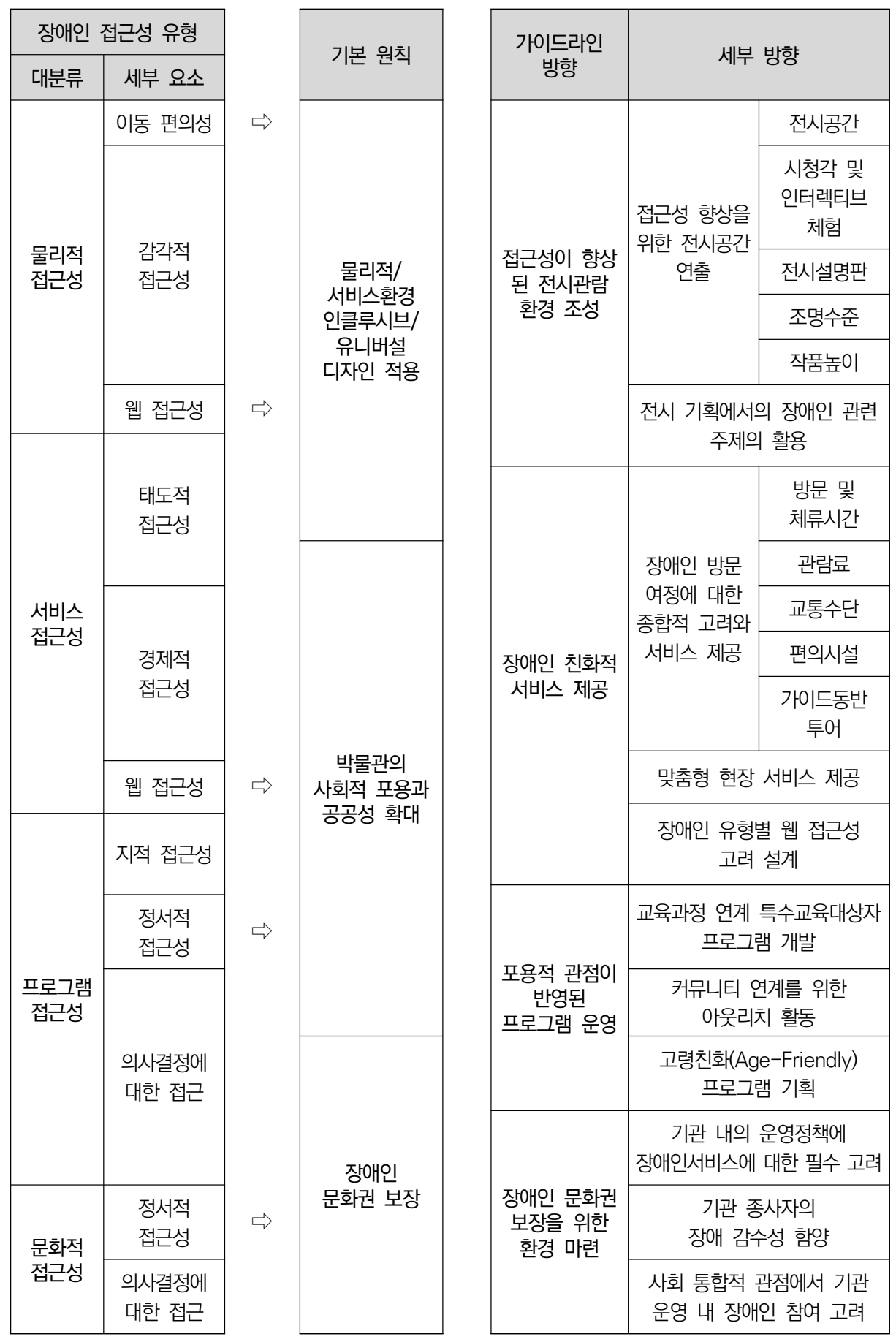




\section{1. 장애의 사회적 모델과 장애인 문화예술 참여}

과거 장애를 질병이나 결함으로 보았던 관점에서는 이러한 치료와 결함을 제거함 으로써 장애가 해소된다고 보았다. 장애의 사회적 모델(Social Model)은 이러한 공 급자 중심의 장애 패러다임을 뛰어넘어 '장애는 사회적 구성물'이라는 전제하에 '장 애는 장애 그 자체가 문제가 아니라 장애를 장애이게끔 하는 그 사회의 구조와 환경 이 문제다'라고 보는 시각이다. 그래서 사회적 모델에서는 장애인이 케어와 치료의 '대상'이 아니라 결정과 선택의 ‘주체’로 거듭나야 한다고 주장한다. 이러한 관점은 장애인이 평등의 기초 위에서 사회의 부분이 되어 장애인이 속한 사회적 문화적 활 동에 참여하는 기회를 확대하면서 사회통합이 될 수 있다는 가능성을 내포한다.

문화예술 활동은 장애인의 사회적 문화적 활동하는 기회를 확대하고 삶의 질을 높이는 데 기여할 수 있다(이민경, 2018). 지역사회 내에 장애인들이 속하면서 다른 사회 구성원과 함께 집단의 일원으로서 자신을 표현하고 자연스럽게 사람들과 상호 작용할 수 있는 곳이 문화 여가활동의 공간이 될 수 있다. 이에 일상생활에서뿐만 아니라 문화예술 및 여가활동에서도 어떠한 제약이나 차별이 없어야 하며, 이를 누 리는 기회를 일반인들과 동일하게 기회가 주어질 필요가 있다. 여기에서 기회는 단 순히 횟수의 기회보다는, 다양한 선택의 기회를 내포한다. 복지나 교육영역에서 포 괄할 수 있는 장애인의 문화예술 활동은 문화예술 활동이 그 자체의 목적이라기보 다 부차적인 수단으로 여겨질 수 있다. 이러한 이유로 그동안 장애인의 문화 활동은 그 중요성이 충분히 인식되고 있음에도 불구하고 사회적으로는 많이 경시됐다.

국민의 문화 향수에 관한 관심이 점차 증가하고 있으며, 예술가들의 창작활동과 향유의 영역에서 분리되는 것이 아닌 '참여’ 적 성격의 중요성이 높아지고 있다. 이 는 누구나 창작의 주체가 될 수 있다는 점에서 문화예술활동을 통하여 주체성을 갖 고 자신에게 내재하고 있는 잠재력을 개발함으로써 자기 삶의 인식을 새롭게 하고 변화와 성장을 기대할 수 있다. 또한, 문화예술의 향유와 참여를 통해 창작, 그리고 더 나아가 예술가로서 나아가고 이들이 양질의 문화예술을 사회에 제공한다는 차원 에서 사회발전에 이바지하는 바가 크다. (Meeting of Cultural ministers, 2018) 이는 장애인에게도 마찬가지로 적용될 수 있다. 장애인들의 문화예술 향유 활동과 적극적 의미의 참여가 활성화될 경우 관련한 분야에 대한 전문적인 활동도 많아지 
고 이는 결국 장애인이 사회 내에서 목소리를 내고 주체적으로 살아갈 수 있게 하는 중요한 발판이 될 수 있다. 문화예술에 대한 접근(Access)과 참여(Participation)의 문제가 장애인 문화예술 활동에서 있어 유기적으로 작용해야 한다는 점은 해외의 장애인 (문화) 예술 활동 정책과 전략((Meeting of Cultural ministers, 2018)에 서도 나타나고 있다.

박물관-미술관은 도서관과 함께 국가의 중요한 문화시설이자(문화체육관광부, 2019) 예술적 표현과 문화예술 활동의 주 환경으로서, 문화예술에 대한 창조적인 참여를 통하여 지역과 사회에서 배제되지 않을 수 있는 임무를 수행할 수 있다(김현 경, 2017b). 지역의 주요한 문화시설인 박물관·미술관에서의 장애인들의 문화예술 활동에의 참여 기회 확대는 장애인들의 여가 기회 확대와 사회참여 향상을 통하여 사회적 재활과 장애인의 정상화에 이바지할 수 있다. 또한, 비장애인들의 시각을 변 화시킴으로써 장애인복지의 궁극적 목표인 사회통합 실현에 긍정적으로 작용하게 할 수 있다.

이에 본 박물관·미술관 가이드라인에서는 장애의 사회적 모델에 기반을 두고 장 애인의 소극적 의미의 문화예술 향유에 초점을 두는 것이 아닌 적극적 의미의 문화 예술참여를 위한 다양한 접근성의 개선을 목표를 두고자 한다.

\section{2. 문화시설의 특수서비스와 장애인을 고려한 인클루시브 디자인 적용}

일반적으로, 유니버설디자인이란 가능한 최대한의 사용자 요구를 만족시키는 환 경디자인이나 제품 디자인을 말하며, 제품이나 환경을 더욱 많은 사람이 편리하게 사용하도록 함으로써 모든 사람을 위한 생활을 쾌적하게 하는 것으로 정의된다. (문 화체육관광부, 2013) 장애인 시설 또는 편의 제공에 있어 국내에서는 유니버설디자 인이 보편적으로 활용되고 있으나, 박물관·미술관의 특수서비스에 대해 장애인 접 근성을 '강화'하기 위해서는 보편성에서 출발하는 유니버설디자인보다 특수성에서 출발하는 인클루시브 디자인에 대한 고려가 더욱 확대되어야 한다. 앞서 살펴본 바 와 같이 문화예술에 대한 다양한 프로그램, 서비스 등에 대한 장애인의 실제적 이용 을 높이기 위해서는 박물관·미술관 시설에 대한 사용성과 포용성(접근성)이 모두 하 
나의 통합적 틀에서 논의되어야 한다. 이와 같은 사용성의 측면은 현재 유니버설디 자인에 기초하여 장애인의 물리적 편의를 제공하는 차원에서 법 제도적 여건이 갖 춰져 있는 상황이다. 법제도 차원에서의 최소 규정을 지키는 것에서부터 적정 조건 에 이르기까지 더욱더 노력이 필요한 상황이지만, 이에 대한 여건을 어느 정도 갖춰 져 있다고 볼 수 있다.

박물관·미술관의 장애인 접근성 강화는 이러한 유니버설디자인을 바탕으로 인클 루시브 디자인에 대한 적용이 함께 이뤼져야 실현될 수 있다. [그림 5-1]에서 보는 바와 같이 '실제적 이용'에 이루기 위함이다.

\section{[그림 5-1] 사용성과 유니버설디자인/접근성과 인클루시브 디자인}

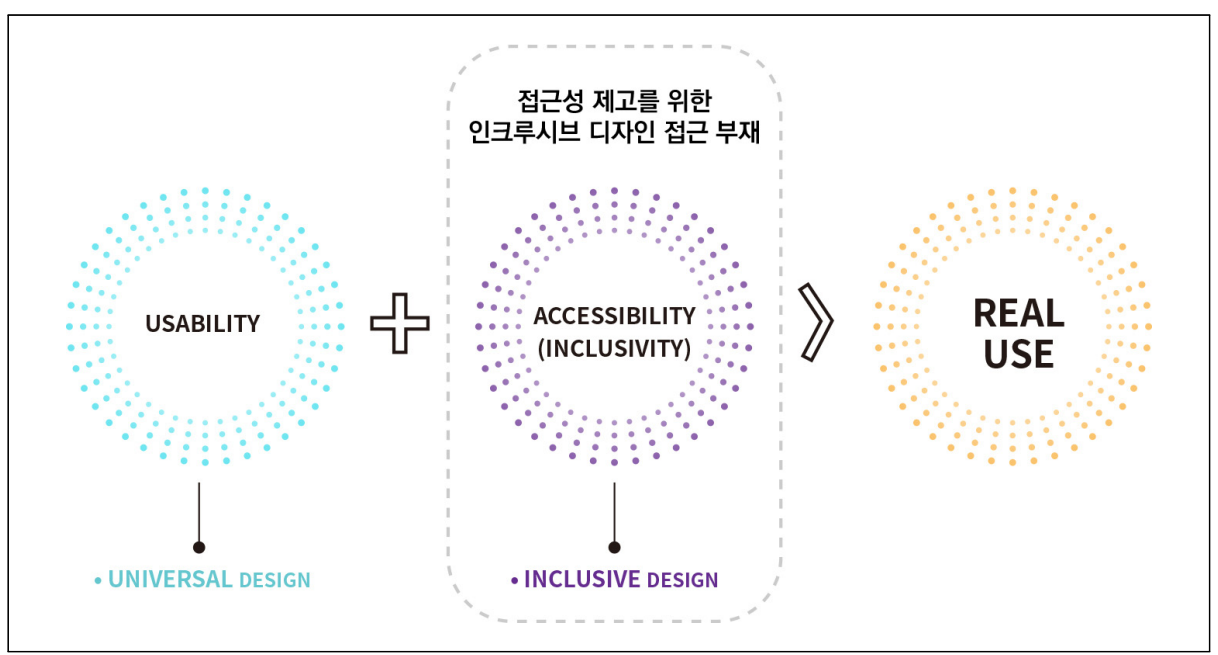

출처: Kim, T. (2015). Characteristics of Inclusive Design and Its Meaning in the Future Society. Archives of Design Research, 28(2), 137-151

이는 장애인과 비장애인을 '분리’ 하는 것과는 다르다. 특수성을 배려하는 것을 우 선순위로 두되, 특수성을 배려한 영역이 보편적인 사람들에게도 거부감 없이 받아 들여질 수 있는 여건을 조성하는 것이 필요하다. 이는 자칫 보편성을 강조한 나머지 애초의 특수한 서비스 제공의 목적을 상실할 수 있는 위험에서 벗어날 수 있도록 한다. 문화시설은 장르별로 특수성 있는 서비스를 제공하는 것을 목적에 둔다. 반면 '유니버설디자인' 은 모든 ‘문화시설'에 '보편적으로' 적용되어야 한다는 원칙 때문 에 이러한 특수성 있는 서비스를 제공하는 기관의 부분적인 요소 가령 예를 들어 
'편의시설'영역에만 적용될 수밖에 없는 실정이다. 모든 관람자를 위한 '보편적인' 디자인이 적용되는 영역은 같은 요구를 전제로 하지만, 문화예술참여 또는 문화향 유 활동은 모든 사람이 서로 다른 취향을 만족하기 위해서 하는 '개인적인 만족'에 서부터 출발하게 된다.

수요조사에서도 드러난 바와 같이, 장애인을 개별적 존재로 바라보는 시각이 필 요하다는 점에서 이와 같은 부분은 박물관.미술관의 장애인 가이드라인 수립에 있 어서 매우 중요하게 다뤄져야 할 부분이다. 다시 말해 특별한 배려가 필요한 장애인 도 개개인 가진 문화예술 취향이 존중되어야 하며, 거기에 특별한 배려가 필요한 것이다. 현재의 장애인 편의법에 따라 '유니버설디자인' 적용을 통하여 이전보다 편 의 제공이 확대된 것과 마찬가지로 문화영역에서는 유니버설 디자인과 함께 인클루 시브 디자인을 고려한 서비스 설계가 중요하며 이틀 통하여 박물관-미술관에 대한 장애인 접근성을 높일 수 있을 것이다. 이에 본 가이드라인은 법적으로 박물관·미술 관의 편의 영역에 적용되는 유니버설디자인뿐만 아니라 특수서비스를 제공하는 문 화시설로서 박물관·미술관의 다양한 정보제공에서의 인클루시브 디자인 적용을 전 제로 한다.

\section{3. 박물관·미술관의 사회적 포용과 공공성의 실현}

장애인들은 사회적으로 배제의 대상이 되는 다른 계층들과 마찬가지로 많은 박물 관·미술관의 권력, 지식, 서비스, 시설, 선택과 기회에 대한 접근이 쉽지 않다. 박물 관과 미술관은 공공성에 기초한 국가의 문화적 여건 마련의 주요한 시설로서 이와 같은 계층을 사회적으로 포용하는데 주요한 역할을 해야할 책임이 있다(Sandell, 2019; 김현경, 2017b). 방문객에 관한 연구, 파트너쉽, 컨설팅, 계획 수립, 평가 등 에 있어 장애인들이 가진 전문지식과 개인적 경험 활용하여 제도적, 개별적 차원에 서 장애인들과 함께 일하는 것을 환영하고 가치 있게 보고 이를 실천하는 것은 박물 관과 미술관이 이와 같은 사회적 포용에 대한 책임을 이행하는 방식이 될 수 있다.

포용, 통합, 다양성은 사회의 구성원들이 자신이 속한 사회 속에서 '존중받는 존 재'로서 위치하는 데에 필수적인 가치가 되어야 한다. 이에 우리 사회에서 문화적 
자산의 보존과 확산에 주요한 역할을 하는 박물관과 미술관은 사회 구성원이 이를 차별 없이 접근하고 누릴 수 있도록 노력해야 한다. 공공서비스는 국가의 예산을 통해서 비영리를 목적으로 수행되며 이에 필요한 수요에 대한 공급의 적정성이 판 단된다. 국가에서 지원을 받는 박물관과 미술관은 일반 국민에게 문화향유의 기회 를 제공해야 하는 문화시설로 교육적, 사회적 역할이 핵심 기능으로 정의되고 정부 에 의해 촉진되어 공공의 이익을 더욱 명확히 보여야 한다. 또한, 관련한 서비스가 원활히 이뤄지기 위하여 더 명확한 목적, 정책 구조, 계획, 모니터링 및 검토의식을 보여야 한다. 이에 본 가이드라인은 관람객의 다양성을 존중하고 접근성의 장애를 없애기 위한 목적하에 이를 구체적으로 계획하기 위하여 활용될 수 있다. 장애인을 위한 접근성 강화는 박물관과 미술관이 공공서비스 제공을 통하여 다양한 계층에게 포용적인 태도를 보이고자 하는 의지를 보여주며 사회통합에 기여하는 기관으로 위 치할 수 있도록 한다. 


\section{제2절 ‘접근성이 향상된 전시’ 관람환경 조성}

장애인 전문가와 실무자들은 박물관.미술관에서 장애인 접근성을 강화하기 위해 서는 방문을 위한 물리적 장벽을 해소하는 것에서 나아가 '접근성이 향상된 전시' 구현이 필요하다고 강조하였다. 이에 본 연구에서는 '접근성이 향상된 전시'를 전시 실 자체를 장애인을 염두에 두고 설계하여 '모든 장애인이 불편 없이 전시에 접근할 수 있는' 환경으로 보고자 한다. 아래에 파악된 영역은 요구 분석을 통해서 확인된 '접근성이 향상된 전시'를 위해 검토해야 하는 영역이다. 이 영역에 대한 점검을 통 해 방문경험을 적극적으로 강화하여 장애인의 방문을 장려할 수 있고, 장애인이 자 립적으로 방문을 했을 때 편안한 관람이 가능할 수 있다. 확인된 주요 영역은 다음 과 같다.

- 전시공간: 전시회 규모/전시공간과 간판의 복잡성

- 전시 설명판

- 조도

- 전시품의 높이

- 기타 전시장 설치물: 진열대 표시/시청각적/촉각적 경험/인터렉티브 체험

관련하여 구체적인 사항을 참고할 수 있는 자료는 국내에서는 2013년 발간된 「유니버설디자인 가이드라인 연구 가 있다. 장애인에게 최적화된 전시 환경 구현을 위한 정보를 좀 더 구체적으로 이해하기 위해서는 국외에서 발간된 〈스미스소니언 전시 디자인 가이드라인(Smithsonian Guideline for Accessible Exhibition Design)〉, 프랑스 문화부에서 발간한 〈Exposition et parcours de visite accessibles〉에 보다 상세한 내용에 대한 가이드라인이 제시되어있다. 


\section{1. 접근성 향상을 위한 전시공간 연출29)}

스미스소니언 가이드라인에서는 '전시란 개념을 전달하고, 사물을 보여주고, 감 각을 자극하는 복잡한 재현 방식'이라고 시작하고 있는데, 이와 같은 복잡한 재현 방식은 하나의 소통의 도구로서 관람자에게 정보와 지식을 전달하는 것을 최종목표 로 삼는다. 장애인의 경우 일반 관람자와는 달리 소통을 위한 언어가 다르고 때에 따라 인지능력도 상이하다. 이들을 위해서 기본적인 물리적 접근성을 확보하는 것 외에도 이와 같은 격차를 해소할 수 있을 때 장애인 친화적인 '접근성이 향상된 전 시'이 구현된다고 볼 수 있다. 다음은 수집된 '접근성이 향상된 전시공간'에 대한 요구사항이다.

\section{가. 전시공간 디자인}

장애인들은 전시공간을 이동하는 것이 공간의 크기나 복잡한 환경 때문에 피로를 쉽게 느낄 수 있다. 적당한 휴식이 가능한 의자 부족은 대부분의 박물관·미술관에서 발생할 수 있는 문제이다. 이러한 문제는 장애인과 고령층과 같이 거동이 불편한 사람들에게 장벽이 될 수 있다.

장애인 편의증진과 관련한 일련의 법령을 통해서 최소단위로서 휠체어가 비치되 어있지만, 휠체어의 관리체계 등에 대해서는 재점검이 필요하다는 것이 전문가들의 의견이었다. 이마저도 대형규모의 국립기관에서 찾을 수 있는 서비스라는 점도 문 제로 지적되었다. 전동휠체어의 이용과 대여가 쉬워질 필요가 있다는 의견이 제시 되었다.

또한, 전시공간이 지나치게 복잡할 수 있다는 점에 주목했다. 그들은 진입점과 출 구 지점을 찾거나 공간을 통해 편안하게 이동하는 데 어려움이 발생한다고 보았다. 안내 지도가 장애인 동선을 고려하여 제작되지 않은 경우가 많고 촉각 표시기 또는 공간에서의 색상 코딩이 부족하다는 점이 지적되었다. 서비스에 대한 방향 표시도 빈약하다고 간주하였다. 너무 많은 텍스트에 의존하고, 충분한 안내 표시가 이뤄지 지 않고 있다.

29) 본문의 구성항목(가 마)의 경우 Australian Museum/National Museum of Australia(2005) 참고 
• 바닥, 계단 및 램프에 촉각 접지 표시기

- 승강기의 오디오 표시기

- 전시 입장 및 퇴장 지점을 명확히 표시

- 전시공간을 통한 움직임을 암시하는 촉각 접지 표시기

- 전시공간이나 박물관을 통한 동선을 유도하는 '색채 유도선'

- 터치스크린 컴퓨터의 지도, 이해하기 쉬운 전시 평면도. 또는 $3 \mathrm{D}$ 로 제작된 모형

- 대형 인쇄물, 읽기 쉬운 간판

- 점자 기호/ 픽토그램 기호

\section{나. 시청각 및 인터렉티브 체험}

다양한 기술이 접목된 전시 디스플레이의 발전에 따라, 전시장 내에 기기를 활용 한 시청각 자료 열람, 인터렉티브 체험 등을 빈번히 볼 수 있다. 이러한 효과나 기기 사용에 대하여 장애인이 느낄 수 있는 반응은 지극히 개인적이라는 것이 전문가들 의 의견이었다. 물론 발달장애인의 경우 주변의 환경에 상대적으로 민감하게 반응 하는 것은 맞으나, 이러한 효과 등에 대해서 호불호가 나뉘는 것은 일반인과 마찬가 지로 개인의 취향과 성향에 따라 좌우된다고 보았다. 시청각 자료가 불쾌하거나 위 험하다고 생각하는 사람들의 우려를 해소하면서 시청각 자료를 즐기는 사람들을 만 족시키기 위해 다음의 조치를 취할 수 있다.

- 관람객이 전시회에 입장하기 전에 시청각 콘텐츠에 대한 경고

- 시청각 자료가 공간을 전체를 구성하는지에 대한 여부

- 시청각 자료를 위한 전용 영역 보유

- 모든 시청각 자료에 대한 캡션 제공

- 오디오 자료에 대한 서면 대안 제공

촉각적 체험과 기타 상호 작용적인 다감각적 체험은 실질적으로는 장애인을 위한 도구이지만, 모든 관람객에게 작품과 유물을 이해하는 데 도움이 될 수 있다. 촉각 적 또는 다감각적 체험이 박물관 체험에 크게 더해지고, 전시의 내용에 훨씬 더 이 
해하는 데 도움이 된다고 보았다. $\mathrm{VR}$ 등의 가상체험 등 인터랙티브한 경험도 지적 장애인에게 흥미를 유발할 수 있는 도구가 될 수 있으며, 이러한 것들을 사전에 공 지하고 활용할 수 있는 가이드가 있는 경우 박물관.미술관 체험을 좀 더 가치 있게 느낄 기회가 될 수 있다고 보았다.

\section{다. 전시 설명판}

일반적으로 장애인들은 전시 설명판에 더 쉽게 접근할 수 있도록 점자, 오디오를 포함한 다양한 유형이 있어야 하며 복잡한 언어를 사용하지 않는 것을 선호한다고 보았다. 설치 위치도 중요하다. 휠체어를 사용하는 사람이 쉽게 읽을 수 있어야 하 며, 시력 장애가 있는 사람들을 돕기 위해 가까이에서 볼 필요가 없어야 한다. 텍스 트에 의존하지 않고도 전시 내용을 설명할 수 있는 오디오 가이드나 도슨트 프로그 램 운영을 통해서 이를 보완할 수 있다.

[그림 5-2] 전시설명판과의 거리와 높이

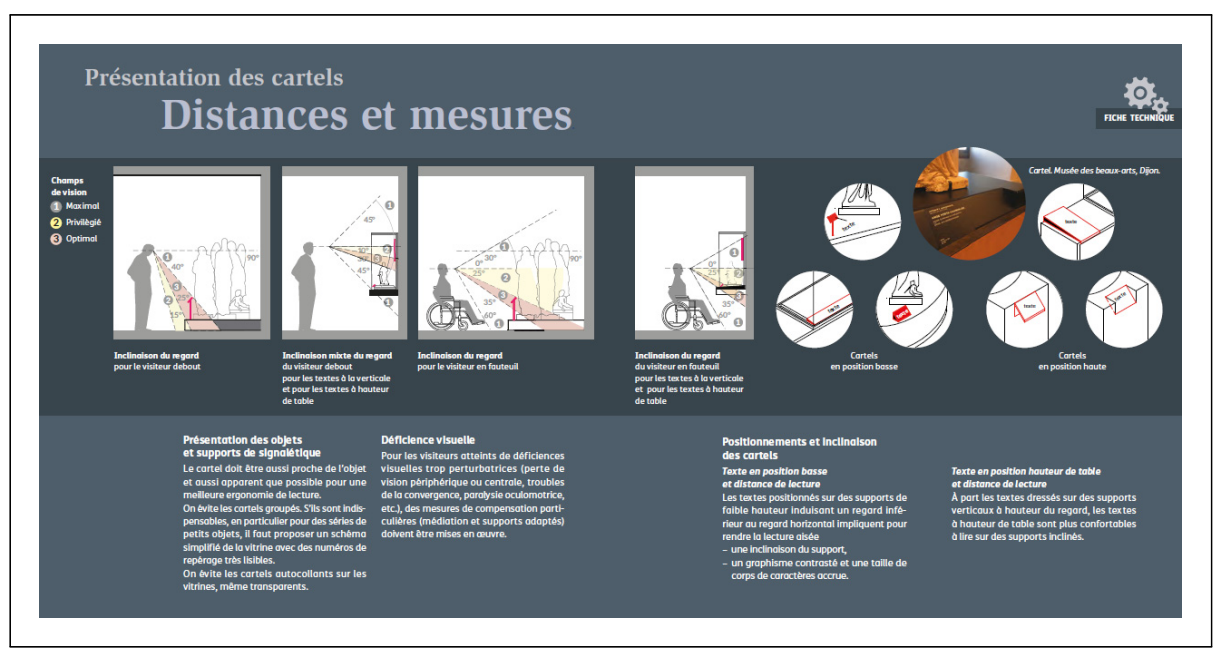

출처: 프랑스 문화부(2017), 「Guide Exposition et parcours de visite accessibles」 


\section{라. 조명 수준}

조명 수준은 다음과 같은 영역에서 장애인의 방문자 경험에 영향을 미친다.

- 라벨을 읽을 수 있는 능력

- 전시회를 통해 쉽게 이동할 수 있는 기능

- 물체와 그림을 명확하게 볼 수 있는 능력

- 청각장애인의 수화 또는 립 리딩으로 의사소통할 수 있는 능력

- 박물관의 전반적인 편안함

요구 분석에 참여한 실무자들은 장애인들이 일부 전시회와 일부 전시물에서 조도 를 낮게 유지해야 할 필요성에 대해 인지하고 있다고 보았다. 박물관.미술관의 상황 은 이해하지만, 실질적으로 수화 통역을 받아야 하는 청각장애인이나 시각장애를 가진 사람들과 같은 장애인 단체 방문 시 좀 더 밝은 조도의 공간 조성이 필요하다.

[그림 5-3] 전시장 조명: 자연광과 인공광 활용

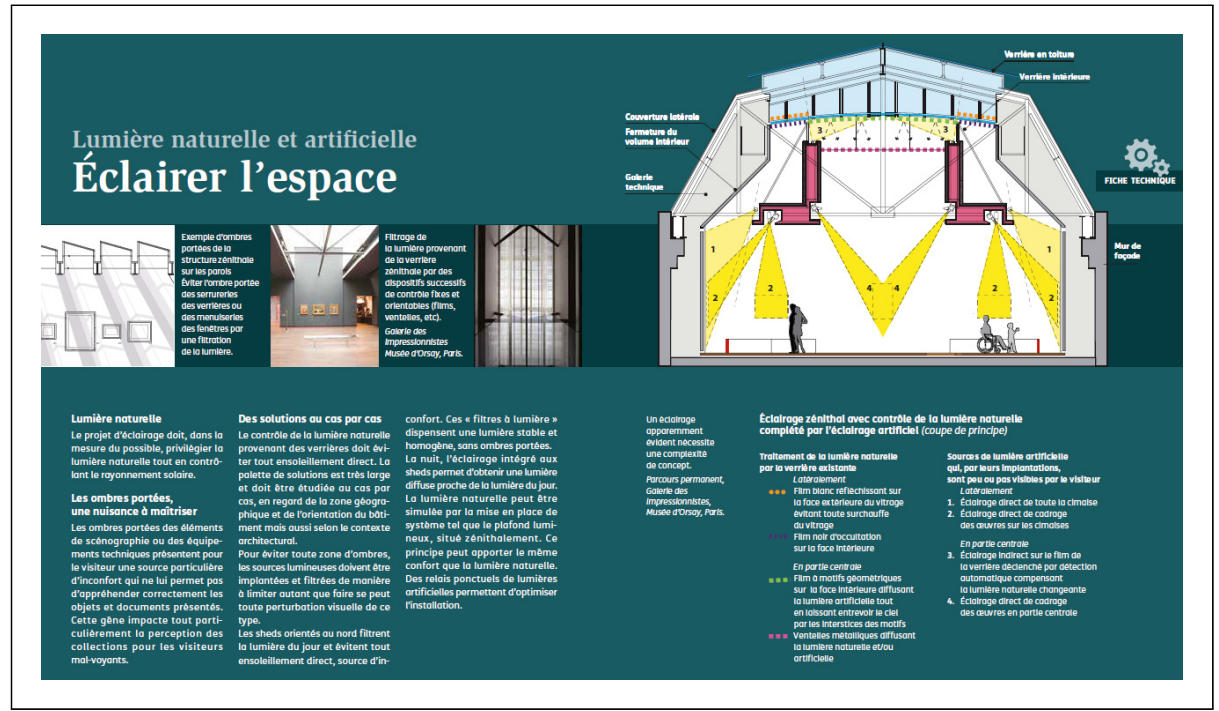

출처: 프랑스 문화부(2017), 「Guide Exposition et parcours de visite accessibles」 


\section{마. 작품의 높이}

작품의 높이는 휠체어를 사용하는 사람, 키가 작은 사람, 어린이(장애가 있는 사 람과 없는 사람 모두)에게 장벽으로 작용할 수 있다. 작품이 눈높이가 낮은 사람들 에게 관람이 어려운 높이에 전시된 경우는 전시 콘텐츠에 대한 접근이 거의 불가능 하다고 봐야 한다. 이에 장애인을 위한 작품의 높이의 경우 휠체어 이용자를 기준으 로 하여 눈높이에 대한 높이에 대학 고려가 필요하다. 물론, 작품의 전시 방식에 따 라 모든 작품의 높이가 휠체어 이용자의 눈높이에 맞춰질 수는 없는 상황이지만, 장애인을 배려한 적정 수준의 높이에 대한 고려가 필요하다. 또한, 전시 진열장과 유리 액자로 작품이 진열된 상황에서 반사 유리의 사용은 특정한 각도에서 보는 것 을 방지한다는 점에서 이와 같은 작품 높이와 복합적으로 전시관람에 한계가 발생 할 수 있다.

\section{2. 전시 기획에서의 장애인 관련 주제의 활용}

장애인 관점에서 박물관·미술관에서 장애인의 대표성을 높이고 장애 경험을 높이 는 전시 기획 등에 대해서 긍정적으로 보았다. 어떤 박물관에서도 장애(또는 장애와 관련된 전시회)에 대한 주제가 다뤄지는 경우 (1) 장애 문제에 대한 인식을 높이고, (2) 고정관념을 허물고, (3) 장애에 대한 긍정적인 표현을 제공하여 장애인에 대한 자부심을 고취하는 데 도움이 된다고 보았다.

더 나아가 모든 문화 또는 역사 전시회에서 장애는 전시 일부로 포함되는 것 역시 도 제안되었다. 장애가 모든 사람이 겪을 수 있는 삶의 경험과 모든 역사와 문화 일부로 인식될 수 있도록 다양한 기획을 통해서 이를 전달할 수 있는 노력이 필요하 다고 보았다. 기획 가능한 주제로는 역사 속 대표 위인 중 장애인 위인의 이야기, 장애의 역사, 장애가 정상적인 생활에 일부라는 것을 이해시킬 수 있는 다양한 관점 의 기획, 장애 예술가들의 잔존감각을 활용한 예술 활동의 결과물들 등이 있다.

또한, 일정 수준의 작품 활동이 가능한 장애인 작가들의 작품을 전시할 기회를 마련하여, 이들에게 문화예술 활동의 적극적인 참여를 통한 사회적 참여의 기회를 만들 수 있다고 보았다. 매년 5월에 진행되는 장애인 주간 기간의 주요한 이벤트로 
서 이와 같은 기획이 이뤄져 장애인들이 박물관·미술관에 좀 더 친근하게 느낄 수 있는 계기를 마련하는 것이 필요하다고 강조하였다.

\section{Rethinking Disability Representation PROJECT}

- 장애 표현을 다시 생각하는 것은 영국의 박물관과 미술관에서 장애의 해석과 장애인의 삶과 경험의 표현 에 대한 새로운 접근법을 개발한 대규모 실험 프로젝트이다. 장애의 사회적 모델에 대한 해석 도면에 대해 정치적으로 인식되는 접근법을 개발하는 것을 목표로 함

- 9 개의 파트너 박물관과 협력하면서, 장애에 대한 대안적(활동을 제시하는 9 개의 프로젝트로 구성

- Talking about... Disability and Art, Birmingham Museum and Art Gallery

- Life Beyond the Label, Colchester Castle Museum

- Lives in Motion, Glasgow Museum of Transport

- Conflict and Disability, Imperial War Museum London

- Istand corrected? Northampton Museum and Art Gallery

- Behind the shadow of Merrick, Royal London Hospital Museum and Archives

- Daniel Lambert: an 'exalted and convivial mind', Stamford Museum

- One in Four, Tyne and Wear Museums

- A Whitby Fisherman's Life: 'Stumper' Dryden through the lens of Frank Meadows Sutcliffe, Whitby Museum

- 이 프로젝트는 RCMG(레스터 대학의 박물관 및 미술관 연구 센터)에 의해 주관함: 헤리티지 복권 기금과 NESTA(National Endowment for Science, Technology 및 Arts)의 자금 지원을 받아 레스터 대학 교와 9개 파트너 뮤즈(Muse)의 기부를 받아 진행됨

출처: DCMS(2008), 「Secretary of State Report on Disability Equality Department for Culture Media and Sport $\lrcorner$ 


\section{제3절 장애인 친화형 서비스 제공}

\section{1. 장애인 방문 여정에 대한 종합적 고려와 서비스 제공30)}

박물관.미술관 방문을 위해서는 방문 장소의 정보습득에서부터 현장 도착, 현장 에서의 관람, 그리고 복귀에 이르기까지 다양한 정보가 필요하다. 장애인의 경우 이 러한 정보가 본인의 장애 유형에 따라 습득 방식 다양하며 방문 여정 또한 다양한 측면을 고려해야한다. 박물관·미술관에서는 장애인의 방문 여정에 대한 종합적인 이해를 통하여 단계별 필요한 정보를 제공해야한다.

우선 단체로 관람하는 경우와 달리 장애인이 개별적으로 방문을 하고자 할 때 [그 림 5-4]에서 보는 바와 같이 방문 전 과정에서 발생할 수 있는 접근성의 문제들을 분석한다. 이후 이를 해결할 수 있는 서비스를 설계하고 적절한 장애 유형별 소통 도구(방식)를 제공할 경우 장애인 방문 편의성이 높아질 수 있다.

[그림 5-4] 장애인의 박물관·미술관 방문여정과 접근성 문제

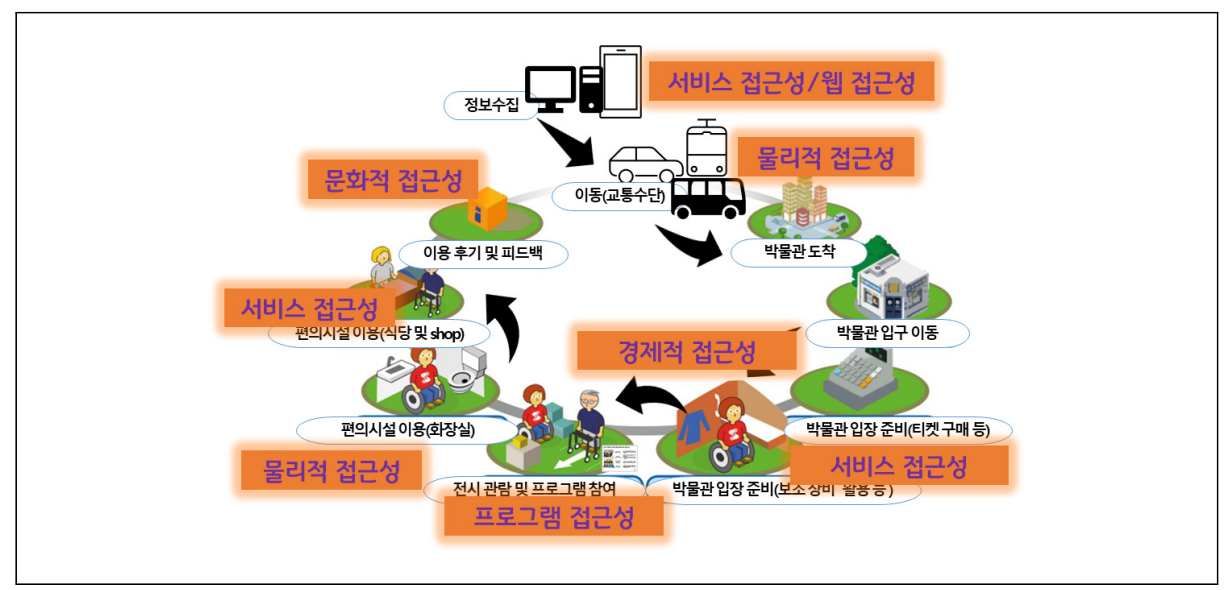

자료: EU(2017), 「Report on the accessibility in Central Europe」내용을 기초하여 연구자 재구성

30) 본문의 구성항목(가 마)의 경우 Australian Museum/National Museum of Australia(2005) 참고 


\section{가. 방문 및 체류 시간}

요구 분석 결과에 따르면 장애인과 보호자를 위한 특별 개방 시간(또는 행사)의 제공이 필요하다고 보았다. 박물관이 다수의 관람객들로 붐비는 시간에는 휠체어 사용자들이 전시품을 실제로 보는 것이 쉽지 않기 때문이다. 평상시 일반 관람객이 방문하는 이외의 시간에 별도 방문 시간을 정하여 진행할 경우 방문 만족도가 올라 갈 수 있다. 현재 국립박물관의 경우 무휴관으로 운영하고 있지만, 휴관일이 있는 기관의 경우 휴관일에 장애인 관람 시간 제공하는 것을 제안할 수 있다. 이 경우 장애인은 인파와 소음이 적은 접근성이 좋은 환경에서 전시물을 관람할 수 있는 기 회가 될 수 있다. 이미 이 서비스를 제공하고 있는 박물관과 미술관은 높은 평가를 받았으며 장애인을 격려하고 환영하는 것으로도 보였다.

\section{나. 관람료}

전시 관람 시 비용이 있을 경우 장애인의 방문의 장벽이 될 수 있다. 하지만 현재 국내 국공립 박물관-미술관의 경우 상설전시에 대하여 무료로 운영되거나, 기획전 시 입장료의 경우도 동반 1 인까지 쟝애인 무료 또는 할인제도가 운영되고 있는 상 황에서 이에 대한 문제제기가 크지 않은 상황이다. 다만, 국공립 박물관-미술관의 상설전시가 아닌 기획전시, 사립 박물관·미술관의 입장료의 경우 장애인에 입장료 에 할인율을 적용하고 있다. 장애인의 경우 비장애인에 비하여 경제적인 어려움을 겪는 비율이 높은 상황에서, 경제적 접근 장벽이 장애인의 문화향유에 어려움으로 작용할 수 있는 가능성이 높다. 이를 고려하여 장애인을 위한 무료 관람 또는 프로 그램 이용에 대한 무료 입장 등을 기관의 운영정책으로 고려할 필요가 있다.

\section{다. 교통수단}

단체 관람이 아닐 경우, 장애인 방문 시 발생할 수 있는 교통수단의 문제는 다음 과 같다.

- 서비스에 대한 정보를 포함한 대중교통 이용의 용이성: 대중교통으로 쉽게 접 근할 수 있는 박물관은 장애인이 방문 선호도가 상대적으로 높음. 반면 대중교 
통 이용 시 입구까지의 이동에 대한 표시(장애 유형별) 등의 문제 발생

- 접근 가능한 주차의 가용성: 장애인이 별도 편의도움을 요청하거나 보안에 연 락할 필요 없이 주차 및 박물관 출입구 근처의 주차가 독립적인 접근이 가능한 지, 장애자 주차 공간이 별도로 마련되어있는지 여부 등

- 택시 승차 및 픽업 지점의 용이성: 택시의 경우『교통약자의 이동편의증진법』 을 통해서 장애인이 쉽게 이용할 수 있는 교통수단임. 승하차 지점과 입구의 거리 등 고려

\section{라. 편의시설}

장애인들 역시 일반 관람자와 마찬가지로 카페 식당, 가게 등을 다양하게 방문하 고 편의서비스 이용에 관심이 높다. 이러한 장소의 방문은 장애인의 경험을 높이고, 박물관·미술관에서 장애인이 ‘환대’받고 있음을 느낄 수 있는 공간이다. 편의시설 중에 화장실 이용은 현재 많은 기관에서 장애인 화장실 설치가 되어있음에도 불구 하고 이용 편의성이 좀 더 높아져야한다고 보았다.

특히, 장애인을 위한 별도의 화장실 공간이 수요실과 마찬가지로 있는 경우 화장 실 내에서 장애인의 사생활 보호가 가능하고 편안함을 느끼며 생리현상을 해소할 수 있기 때문에 이에 대한 설치가 고려될 필요가 있다.

식당과 레스토랑의 경우 단체 관람일 경우 이용하기가 용이하지 않을 수 있기 때 문에, 별도의 공간을 통해서 장애인 단체들이 점심을 해결할 수 있는 공간이 전시장 과 멀지 않은 곳에 설치되는 것 역시 필요하다.

\section{마. 가이드를 동반한 투어}

가이드 투어는 박물관이나 전시회에 대한 더 많은 정보를 얻을 수 있는 방법으로 여겨진다. 교육 경험을 향상시키고, 장애인들에게 호기심을 유발 시킬 수 있기 때문 에 가이드 투어가 박물관·미술관을 더 쉽게 접근할 수 있도록 한다고 보았다.

가이드 투어는 기본적으로 (1) 체험의 모든 측면이 신체적으로 접근 가능하도록 보장하고 (2) 가이드와 가까이 서야 하는 감각장애인을 위한 행동 매뉴얼이 있어야 하며 (3) 수화 등이 가능한 모든 장애인이 충분히 접근할 수 있는 가이드 투어가 제 
공되어야한다. 모든 가이드 투어에 있어 장애인의 욕구가 충족되도록 하기 위한 장 애 인식 교육이 필요하다.

장애인 단체를 위한 전용 가이드가 있는 소규모 그룹 형태의 진행을 통하여 전시 를 좀 더 잘 이해할 수 있도록 할 수 있다. 전시관 내에 촉지 보조 도구 등이 잘 설치되어있는 경우, 이를 중심으로 한 촉각 투어 등을 통해서 시각장애이들의 만족 도를 높일 수 있다. 촉각 투어의 경우, 장애인이 아니더라도 일반인들도 작품에 대 한 이해와 흥미를 유발하는 데에 효과가 있다.

\section{2. 맞춤형 현장 서비스 제공}

박물관·미술관을 방문하는 장애인은 현장에서 이동과 시설 이용 등에 지원이 필 요하다. 이러한 지원에 대하여 장애 유형별로 맞춤형 현장 서비스가 제공될 경우, 장애인들이 박물관·미술관 방문에 좀 더 친숙해지고 이에 대한 긍정적인 인상을 얻 을 수 있다.

맞춤형 현장 서비스는 고객 응대의 영역으로서 대면 서비스 제공과 보조 기구 제 공으로 구분될 수 있으며 동시에 이뤄질 경우, 현장에서의 정보 습득과 서비스 이용 의 편리성이 높아진다. 단체 관람의 경우, 단체의 이동 동선과 방문 예약, 체류 시 간, 활동 내용 등을 사전에 조율하는 방식으로 맞춤형 현장 서비스가 제공 될 수 있다. 맞춤형 현장 서비스 제공에서 가장 중요한 것은 정보 제공자가 장애 유형별로 응대 방식을 숙지하고 있어야하며, 소통의 도구 역시 모든 장애인들이 충분히 접근 할 수 있는 도구들이 제공되어야한다.

장애유형별로 맞춤형 대면 서비스를 제공하는 것이 박물관·미술관의 인력으로 충 당하는 데에 한계가 있다. 이 경우, 장애인을 대상으로 박물관·미술관 자원봉사 혹 은, 또는 보조 동반자 등의 역할을 제안할 수 있다. 이들이 박물관·미술관의 (보조) 인력으로서 운영에 참여하고 관여할 수 있는 기회가 확대되고 확산되면 이들의 목 소리를 통해서 박물관·미술관의 장애인 현장서비스가 '사용자 친화적'으로 변화될 수 있는 가능성이 높다. 이러한 활동에 대한 장애인들의 참여 의사는 높을 것으로 요구 분석 결과에서 나타났다. 
실례로 국립현대미술관의 경우 장애인 프로그램 진행 시, 서울문화재단의 잠실창 작스튜디오 장애 예술가들을 강사로 초빙하고 워크샵 등을 통하여 일반인들과는 다 른 장애인들의 관람 방식과 동선 등을 상세히 파악하였고, 이를 고객 지원팀 쪽으로 전달하여 미술관 서비스 개선하도록 하였다. 맞춤형 서비스의 경우 장애 유형별로 세밀하게 설계될 필요가 있으며, 유형별 장애인들의 니즈 분석과 패르소나 분석 등 을 통한 이용자의 서비스 요구 분석을 기초로 개별영역과 공통영역을 구분하여 다 양한 서비스들을 설계할 수 있다. 이는 본 가이드라인 수립 방향을 기초로 진행되어 야할 '장애인 유형별 박물관미술관 이용 가이드라인' 등에 반영되어야할 것이다.

\section{참고 사례: 시립 서대문농아인 복지관 박물관 청각장애인 관람객을 위한 수어해설영상 제작}

- 시립서대문농아인복지관은 GKL사회공헌재단의 지원으로 서울시 박물관에 청각장애인 관람객을 위한 수 어해설영상을 제작

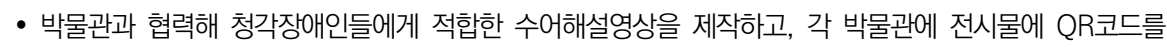
부착해 해설서비스를 이용

- 스마트폰을 이용해 QR코드를 찍으면 수어해설영상을 볼 수 있으며 동일한 영상은 muv.deafgogo.com 모바일웹페이지 열람가능

출처: 시립 서대문농아인복지관 홈페이지(2020.08.15. 접속 기준)

\section{참고 사례: 발달장애인을 위한 알기쉬운 자료 제작 사회적 기업 '소소한 소통'}

- 발달장애인을 위한 정보를 좀 더 쉬운 방식으로 재제작해주는 사회적 기업

- 쉬운정보제작, 디자인 지원, 교육 및 자문 활동을 중심으로 이뤄짐

\section{소소의 쉬운 정보 제작}

문서, 책, 각종 서식, 뉴스, 교육·홍보자료 등을 보다 쉽게 만듭니다. 글은 쉬운 표현으로 바꾸고, 이해를 돕는 그림을 함께 그려 넣어 더 많은 사람들이 알기 쉽게 합니다.
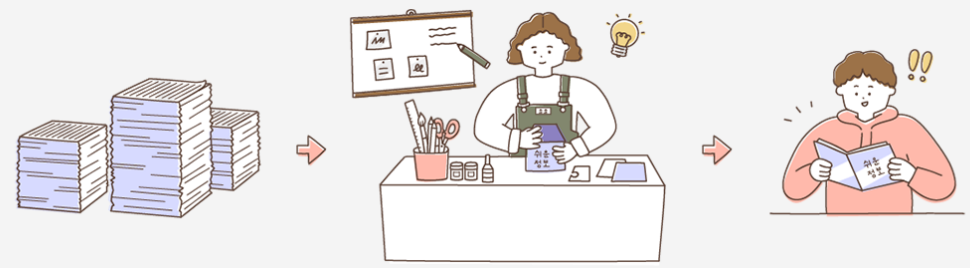

출처: 소소한 소통 기업 홈페이지 (2020.09 접속기준) 


\section{참고 사례: 영국대영박물관 sensory map}

- 대영박물관의 경우 홈페이지에 장애인을 위한 sensory map을 다운로드 받을 수 있도록 하여 청각, 시각 장애인들이 본인들에게 필요한 서비스의 위치와 동선 등을 미리 파악할 수 있도록 하고 있음

[그림 5-5] 편의시설 상세 지도

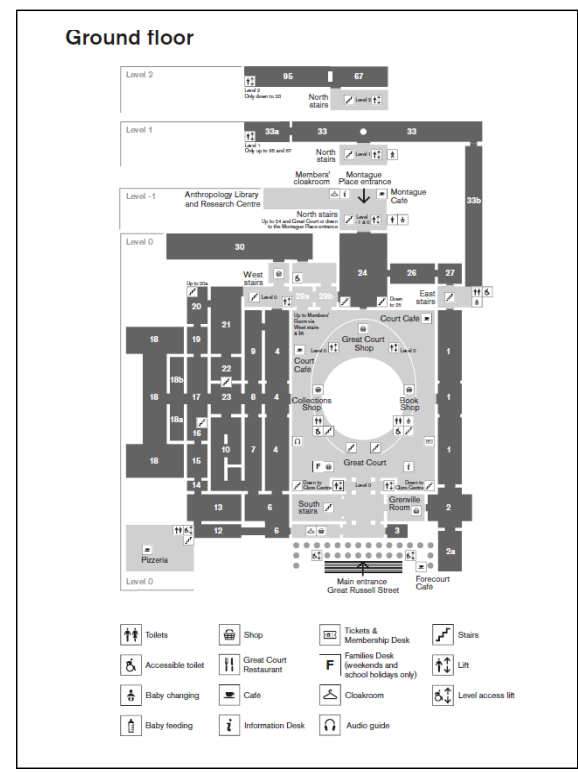

출처: 대영박물관 홈페이지(2020.09 접속기준)
[그림 5-6] 공간 내 동선을 색으로 표현하여 구분

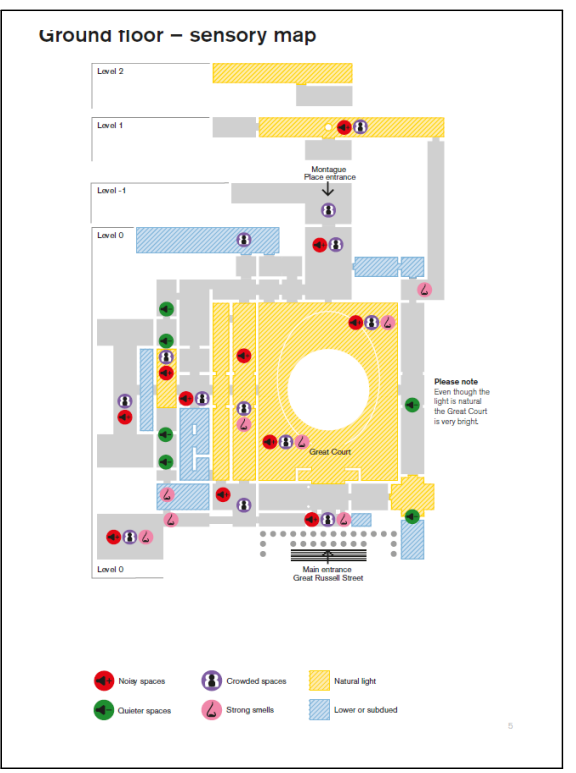

\section{3. 장애인 유형별 웹 접근성 고려 설계}

인터넷은 박물관에 첫 소개로 장애를 가진 많은 사람들에 의해 사용되기 때문에, 웹사이트들이 가능한 한 접근할 수 있는 것이 필수적이다. 월드 와이드 웹 컨소시엄 (W3C)과 웹 접근성 이니셔티브(www.w3.org/WAI),)는 전 세계 기관과 협력하여 웹 접근성을 연구하고 온라인 정보의 접근성을 높이기 위한 일련의 기술 표준과 지 침을 제공한다. 모든 사이트는 최소한 최소 기준을 충족할 것을 권장한다. 웹사이트 는 시각장애인, 시각장애인, 난독증 환자 및 운동능력 장애인과 같은 광범위한 사용 자의 요구를 고려해야 한다. 페이지는 음성, 점자 및 일반 텍스트 기반 브라우저, $\mathrm{PDA}($ Personal Digital Assistant), 검색 엔진 및 프린터와 같은 광범위한 웹 지원 
장치에서도 접근할 수 있어야 한다.

국내에서 법적 의무사항으로 한국웹접근성인증평가원을 통해서 웹 접근성을 인 증하고 있다. 하지만 이러한 인증과는 별도로 웹에서 장애인들이 필요로 하는 내용 과 콘텐츠를 별도의 페이지를 통해서 제공할 수 있어야한다.

해외의 경우, 이러한 정보 제공 차원의 적극적인 서비스 제공이 이뤄지고 있다. 장애인들을 위한 별도의 홈페이지(ACCESS 또는 ACCESSIBILITY 항목)를 통하여 장애인들이 박물관·미술관의 정보과 콘텐츠를 온라인을 통해서 충분히 얻을 수 있 다. 이 정보는 방문 사전 준비와 방문 중에도 활용이 가능하며, 방문 이후의 학습도 움이 될 수 있도록 정보를 제공하고 있다.

\section{참고 사례: 미국 MOMA Accessibility 홈페이지}

- Accessibility 메인 페이지에 각 장애유형별로 별도 페이지로 연결될 수 있도록 함

- 편의제공 서비스 지도와 장애인 방문 여정별 행동 지침과 관련한 이용공간 지도를 별도로 다운로드 받을 수 있도록 함

[그림 5-7] 모마 장애인 홈페이지

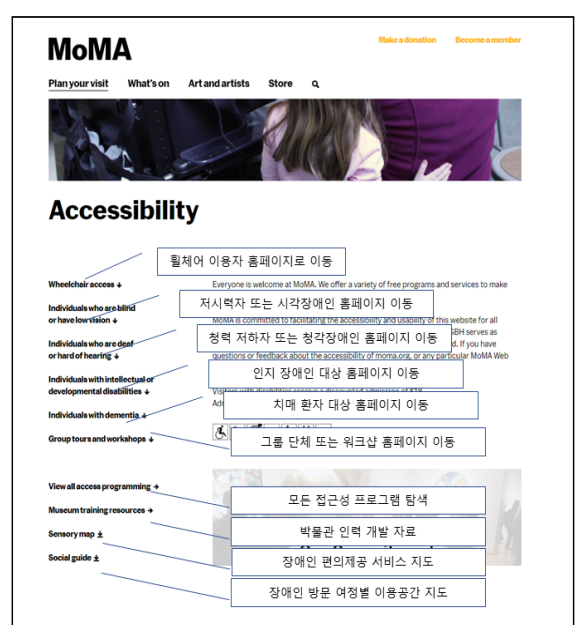

[그림 5-8] 시각장애인의 감각에 대한 설명 영상

\section{Individuals who are blind or have low vision}

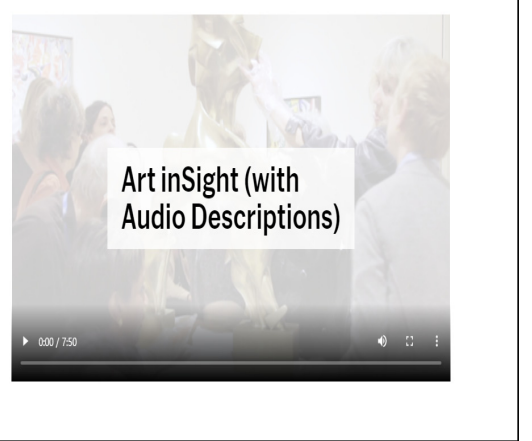

출처: MOMA Accessibility 홈페이지(2020.08.15. 접속 기준) 연구자 번역 


\section{제4절 포용적 관점이 반영된 프로그램 운영}

\section{1. 교육과정 연계 특수교육대상자 프로그램 개발}

장애인의 박물관.미술관 교육에 대한 요구는 개인 간의 차이를 존중하고, 개인의 특정성을 강조한다(이가나, 2010). 그렇기 때문에 박물관·미술관의 다른 어떤 프로 그램보다도 장애 유형이나 특성을 고려하여 운영되어야하는 것이 교육 프로그램이 다. 하지만, 일부 국립 박물관과 미술관의 사례를 제외하고는 관련한 프로그램을 정 기적으로 운영하지 못하고 있기 때문에 유형화 등을 기대하기 어려운 실정이다.

그나마 교육프로그램에서 가장 특화되는 부분은 특수아동 대상 교육 프로그램인 데, 학령기 자녀가 장애인일 경우 교육을 통해서 사회적 참여를 이끌어내려는 학부 모들의 열정이 높다는 것이 실무자들의 의견이었다. 이와 같은 학령기의 아동의 경 우 특수교육대상자로서 특수학교 또는 일반학교의 특수학급에서 의무교육을 받도 록 하고 있기 때문에 이들과의 연계를 통해서 프로그램을 연계 활성화 할 수 있는 가능성도 높은 영역이라고 강조했다.

학교와의 연계를 위해서는 가장 중요한 것은 교과과정은 연계로 보았는데, 일반 학교의 특수학급의 경우 문화예술분야는 공통 학습영역으로 일반학생들과 통합적 으로 교육을 받도록 하는데 이러한 사회적 교류의 장으로서 박물관.미술관 현장학 습과 그곳에서의 교육이 긍정적인 효과를 얻을 수 있다고 보았다.

이를 위해서 국립한글박물관(2018)에 따르면 특수학교(급) 장애학생의 박물관 체 험학습 방해요인을 다음의 세가지로 보고 있는데, 지원 인력의 장애 이해와 장애 공감도 부족, '장애'특성을 고려하지 못한 프로그램 운영, '장애'를 고려한 프로그램 구성과 홍보 필요 등이다. 이를 해소하기 위하여 제시된 교육 프로그램의 개발 및 운영 방향은 다음과 같다.31) 
- 장애 학생의 사회·인지적 특성을 고려하여 장애학생이 직접 체험하며 참여할 수 있는 별도의 내용을 구성하는 것이 바람직함

- 체험학습 프로그램을 운영하는 전문 지원 인력은 물론 박물관 내 직원 모두 장 애 이해의 장애 공감 능력을 갖추어야 하며 이를 위한 장애 이해 교육이 필요함

- 특수학교(급)에 재학하는 다수의 발달장애학생이 박물관의 교육 프로그램을 경 험할 수 있도록 적극적인 홍보 필요

- 특수학교(급) 장애학생이 현장체험학습 장소로 박물관을 쉽게 방문할 수 있도 록 차량 지원등의 편의가 제공되는 것이 필요함

- 찾아가는 박물관 교육 프로그램을 제공해줄 수 있는 방안 모색

- 타 박물관과의 교육 프로그램 교류를 통하여 관련 분야 확산과 범 국민적인 장 애인식에 기여 하도록 함

\section{참고 사례: 국립현대미술관 장애아동·청소년 가족프로그램 〈어떤 감각〉}

- 동시대 현대미술 작가들과 함께 설치미술, 퍼포먼스 등 다양한 방식의 현대미술 작품을 감상하고 표현하 면서 온 가족이 소통할 수 있는 놀이형 워크숍

- 자폐범주성 장애, 지적장애 등 발달장애 아동 및 청소년을 대상으로 하며, 장애아동·청소년의 형제, 자매, 부모 등 가족 전 구성원이 참여하실 수 있는 가족프로그램

- 1 가족당 최대 4명까지 참여, 전체 참여 인원은 회당 20 명 내외로 제한

- 연령 별 대상을 구분하여 어린이(만7세 11세)와 청소년(만 12세 17세) 으로 운영 어린이 또는 청소 년 프로그램 중 선택하여 참여 가능

자료: 국립현대미술관 교육프로그램 홈페이지(2020.08.15. 접속 기준)

\section{참고 사례: 국립박물관미술관 특수아동교육 관련 프로그램 개발 자료}

- 국립고궁박물관(2011), 시각장애아동대상 교육프로그램 개발 연구용역 보고서

- 국립고궁박물관(2011), 청각: 나누며 행복한 궁중음식

- 국립현대미술관(2012), 특수아동을 위한 미술관 교육 활성화 방안 연구

- Kojiro Hirose(2013), Research on Methods of "Touching the World" -The Aim of the Exhibit Area of Tactile Learning in Japan's National Museum of Ethnology

- 국립고궁박물관(2013), 조선 왕실문화 활용 예술치료 프로그램 개발

- 국립현대미술관(2016), 장애인대상 미술관교육 워크숍 ‘모두의 미술관을 위한 라운드 테이블'

- 국립한글박물관(2018), 국립한글박물관 장애인 대상 교육 프로그램 개발 연구(발달장애)

- 국립중앙박물관(2020), 시각장애인 교구 개발 및 교육 운영 자문 결과

31) 제안된 내용은 국립한글박물관에 초점을 두고 있어 연구자가 국립한글박물관을 박물관이라는 일반 주체로 변경하여 기입함 


\section{2. 커뮤니티 연계를 위한 장애인 아웃리치(outreach)프로그램}

문화생활에 대한 정보와 욕구가 높아지는 추세임에도 불구하고 장애인들의 문화 향유 활동은 여전히 소극적으로 이뤄지고 있다.

아웃리치 프로그램을 이러한 소극적인 형태의 문화향유 활동에 대한 장벽을 넘어 서 박물관.미술관이 가지고 있는 다양한 콘텐츠와 정보, 지식 등을 개방하기 위해서 필요하다. 박물관·미술관이 지역사회에 손을 내밀어 네트워킹하고, 협력관계를 맺 는 것이다. 아웃리치 프로그램은 방문 프로그램에 비하여 좀 더 이용자의 '삶'에 직 접적으로 다가갈 수 있는 장점이 있다. 이러한 특징으로 장애인에 대한 아웃리치 프로그램은 그들의 '삶'에 문화적인 접근을 가능하게 한다. 단순히 방문이 어려운 사람들은 돕는 차원이 아닌 그들의 일상을 함께 공유하면서 문화를 통하여 삶의 만 족도를 높일 수 있다. 또한 직접적으로 정보를 수집하기 어려운 장애인의 경우, 좁 은 경로의 정보만을 습득할 수 있는데 이러한 아웃리치 프로그램을 통한 다양한 문 화적 경험을 얻을 수 있다. 아웃리치 프로그램이 단순히 공급자와 수혜자의 관계를 통해서 이뤄지는 것은 아니다. 조직 내부적으로도 새로운 아이디어와 피드백을 통 해 소장 컬렉션해석과 활용을 확장하고 새로운 시각을 제시할 수 있다. 참여자 개념 을 확대하여 박물관·미술관의 포용적 환경을 조성하는 데 중요한 역할을 할 수 있 다. 방문객이 아닌 참여자로서 장애인이 지식과 정보에 대하여 완전하게 관여하여, 수동적인 정보 수신자가 아닌 능동적인 공동체로서 성장할 수 있으며, 이는 사회 통합적으로 긍정적인 효과를 가져올 수 있다.

\section{참고 사례: 국립고궁박물관 문화 소외지역 어린이-장애아동 대상 「찾아가는 박물관}

- 「찾아가는 박물관」은 지역적·신체적 이유 등으로 박물관에 오기 어려운 어린이들을 위해 교육 대상자를 직접 찾아가는 수요자 중심의 문화유산 3.0 맞춤형 프로그램

- 전교생 100명 미만 학교와 장애 특수 학급 학교를 대상으로 진행(한회당 약 15명 미만 진행)

- 2014 2017년 까지 경기도, 강원도, 충청남도, 충청북도 매년 광역지자체를 순회하며 진행하였음

- 박물관의 주요 소장품 및 콘텐츠인 왕실문화와 관련한 다양한 지식과 정보를 체험을 통해서 습득할 수 있도록 프로그램 구성(전담교사 3인, 지원인력 2명, 차량 지원)

자료: 기획재정부 보도자료(2015.04.22.) “기재부·문화재청, 초등학생 대상 ‘찾아가는 박물관 운영' 


\section{3. 고령친화(Age-Friendly) 프로그램 기획}

고령화 인구 증가에 따라, 관련 정책에 대한 중요성이 높아지고 있다. 고령화에 따라 신체의 변화와 함께 장애를 갖게 되는 경우가 많으며, 다른 한편으로는 장애인 의 경우고 고령 인구가 증가하고 있는 추세이다(복지부, 2018) 관련하여 고령친화 (Age-Friendly) 환경 조성 및 관련 정책 마련에 대한 관심이 높아지고 있다.

고령 친화의 개념은 세대 간 활발한 상호작용으로 갈등을 예방하고, 연령과 무관 하게 다양한 사회적 활동을 개인의 욕구와 능력에 따라 선택하여 독립적이고 자율 적인 삶을 영위하는 연령 통합의 개념으로 이해할 수 있다.(이상철 외, 2016)

최근 박물관·미술관을 중심으로 빠르게 확대되고 있는 고령인구에 대한 대응으로 고령 친화적인 프로그램에 대한 관심이 높아지고 있다. 고령 친화의 개념은 세대 간 활발한 상호작용으로 갈등을 예방하고, 연령과 무관하게 다양한 사회적 활동을 개인의 욕구와 능력에 따라 선택하여 독립적이고 자율적인 삶을 영위하는 연령 통 합의 개념으로 이해할 수 있다.(이상철 외, 2016) 이는 박물관·미술관 교육 프로그 램에서 '치매'를 갖게 된 고령자들이 기억을 환기함으로서 치유와 어느 정도의 치료 적 효과를 얻도록 하는 프로그램(일본, 미국 사례) 에서부터 예술 참여를 통해서 시 회적 고립에서 벗어나고 심리적 안정을 유도하는 등의 프로그램이 활발하게 전개되 고 있는 추세이다. 물론, 아직까지는 고령자로서 장애인들에 대한 배려가 많이 부족 한 현실이지만, 이러한 고령자 친화적인 프로그램의 확산과 생애주기적 접근을 통 해서 박물관·미술관의 장애인 접근성이 한층 강화될 수 있다.

\section{참고 사례: 국립현대미술관 치매환자와 가족을 위한 미술관 교육}

- 2015년부터 대한치매학회와 공동으로 기획하여치매환자와 가족을 위한 미술관교육 운영

- 60 세 이상 경도인지장애 및 치매가 있는 어르신과 가족을 대상으로 하는 가족프로그램 - 반드시 가족(1 명 이상)과 함께 참여가 가능, 전체 참여 인원은 회당 25명

\begin{tabular}{|c|c|}
\hline 구분 & 내용 \\
\hline $\begin{array}{c}\text { 과천 } \\
\text { (1회 과정) }\end{array}$ & 과천관 야외조각공원 산책 및 자연과 함께하는 현대미술 감상, 교감 프로그램 진행 \\
\hline $\begin{array}{c}\text { 서울 } \\
\text { (4회 연속과정) }\end{array}$ & $\begin{array}{l}\text { 〈박서보: 지칠 줄 모르는 수행자〉 전시감상을 통해 가족의 행복했던 기억과 일상을 } \\
\text { 새롭게 발견하는 프로그램 진행 }\end{array}$ \\
\hline $\begin{array}{l}\text { 덕수궁 } \\
\text { (1회 과정) }\end{array}$ & $\begin{array}{l}\text { 덕수궁관의 미술관 건축물과 고궁에 담긴 역사, 시대의 흔적을 돌아보며 자기의 이야 } \\
\text { 기를 떠올리고 공감하는 프로그램 진행 }\end{array}$ \\
\hline
\end{tabular}

자료: 국립현대미술관 교육프로그램 홈페이지(2020.08.15. 접속 기준) 


\section{제5절 장애인 문화권 보장을 위한 환경 마련}

\section{1. 기관 내의 운영정책에 장애인서비스에 대한 필수 고려32)}

차별적 관행과 서비스 부족을 해결하는 가장 좋은 방법은 장애인 서비스에 대한 운영 정책과 실행 계획을 준비하는 것이다. 이를 위해서는 조직 내에서 차별의 영역 을 발견하기 위한 내부 점검과 확인된 문제해결을 위한 액션플랜 등이 필요하다. 실행 계획의 개발 및 구현은 기관의 이미지 제고, 보다 효율적인 서비스 제공, 보다 넓은 차원의 관람객 접근 확대와 포용적 역할 수행에 기여할 수 있다. 이러한 실행 계획은 지속적으로 피드백을 통해서 정기적으로 점검해야한다. 정책 수립과 액션플 랜 수립을 이해서 다음의 요소를 고려해야한다.

- 장애가 있는 사람 및/또는 그 대표적인 조직과 협의

- 정책 및 관행 검토

- 장애인이 서비스에 접근하는 데 있어 장애인을 위한 장애물 식별

- 이러한 장벽을 제거하기 위한 전략 계획

\section{가. 정책 및 서비스 점검과 평가}

해외의 선행연구를 통해 살펴보면, 장애인 활동과 관련한 전문가가 수행하는 건 물, 서비스, 정책 및 관행에 대한 철저한 점검이 장애인을 위한 포용적인 서비스 제 공과 접근성 강화에 대한 조직의 의지를 입증하는 가장 효과적인 방법이라고 지적 한다(Australian Museum/National Museum of Australia, 2005). 장애접근계 획 또는 정책이 마련되었다고 해도, 구체적인 계획과 이 계획의 적용이 효과적인가

32) 본문의 구성항목(가, 나)의 경우 Australian Museum/National Museum of Australia(2005) 참고 
지속적으로 점검할 필요가 있다. 박물관-미술관 진흥법에 의거하여 문화체육관 광부에서 실행하고 있는 〈박물관·미술관 인증평가 제도〉에서 장애인 서비스와 관련 한 영역이 포함되어있으며, 이 지표에 부합하는 관련 서비스 확대와 장애인 접근성 개선이 이뤄질 수 있다.

\section{참고 사례: 영국 NDNW(2019), Age-Friendly Museums Checklist}

MDNW(Museum Development North West)는 Family Arts Campaign33)의 허가를 받아 연령 친화 를 위한 체크리스트를 박물관 분야에 맞게 수정하여 조직에서 디지털 방식으로 체크리스트를 완료하고 저장 할 수 있도록 하였다. MDNW의 연령 친화적 접근성 프로그램 일환으로 수행된 지표 마련작업은 MDNW 연령 친화적 박물관에 대한 홍보 자료 출간과 함께 이뤄졌으며 여기에는 프로그램에 참여한 6 개 박물관의 사례 연구가 포함되었다.

연령 친화적 표준 자체 평가 체크리스트는 연령 친화적 표준에 대한 조직의 진행 상황을 평가하고 모니터링 하는 데 도움이 되도록 설계되었다. 또한 조직적 맥락에서 달성할 수 있는 것이 무엇인지에 대해 어떻게 더 개선할 수 있는지를 고려하였다. 주요 고려사항은 다음의 2가지로 요약할 수 있다: 시설 이용에 있어 노인들이 어려움을 겪을 수 있는 모든 제한 사항을 검토하고 이와 같은 제한 사항을 개선을 위해 우리는 무엇을 해야하는 가에 대한 고민

치매와 같은 특정한 조건들을 다루는 경우가 있기 때문에, 연령 친화적 표준은 기존 지침을 복제하거나 대체할 수 없는 영역이다. 이러한 까닭으로 Family Arts Campaign은 유용한 링크 및 리소스 웹 사이트에 추가 전문가의 조언을 위한 참조 섹션을 제공하도록 연계하였다.

연령 친화적 표준 자체 평가 체크리스트를 작성을 통하여 기관의 고령으로 인하여 발생할 수 있는 장애를 가진 관람자들에게 좀 더 편안한 박물관 서비스를 제공할 수 있으며, 더 나아가 이 분야의 개선을 위한 근거 자료를 마련하여, 영국 박물관미술관 인증(Museum Accreditation scheme) '사용자 및 경험' 요건 에 대한 기관에서의 활동 진행 상황 및 대처 역량을 보여주었다.

\section{참고 사례: 영국 Vocaleyes(2016;2018) museum access information Guidelines}

Vocaleyes는 민간단체로 영구 시각손실 장애 또는 부분적 시각 장애자에 대하여 제공하는 영국 전역의 1,700 개의 박물관 웹사이트에 제공된 정보를 기준으로 그 장소에 대한 접근(장소 또는 행사장 도착 방법의 설명)을 조사하고 실태를 파악함으로서 관련한 서비스 제공의 보완과 개선을 촉구하고 있다.

각 박물관의 홈페이지를 기준으로 진행하는 조사 내용은 다음과 같다.

- 장소까지 가는 방법의 방향 또는 설명

- 장애인 방문객 및 안내견/보조견 동행가능 여부

- 장소 내 자원 접근성: 큰 글씨 제공(Large Print (16pt 이상), 촉각 지도, 수유시설, 오디오 해설 투어 및 가이드 등

조사는 정량적 차원에서 정보의 유무 확인을 중심으로 그 정보의 품질이나 내부에서 기술된 자원이나 프로 그램을 판단하지 않았다. 웹사이트의 접근성 특징과 박물관이 제작한 다른 마케팅 자료와 출판물은 고려하 지 않았다.

33) 영국의 국가 지원 기관으로 예술과 문화를 통한 가족간의 연계를 높이는 영역을 지원하는 기관 


\section{참고 사례: 영국 Vocaleyes(2016;2018) museum access information Guidelines}

정부의 성과 보고서에 따르면, 박물관이 공공 건축물 중에서 장애인에게 '좋은' 접근성을 가진 것으로 평가 받고 있는데, Vocaleyes의 조사 결과에 따르면 정부의 평가와는 달리 실질적으로 많은 박물관들이 장애인 을 환영하고자 하는 태도를 취하지 않거나, 정보를 적극적으로 제공하는데 미흡하다는 것을 알 수 있다. 또한 지자체의 경우 개별 홈페이지 등을 갖지 못하여 이에 대한 정보를 충분히 습득하는데에 한계가 있다는 점을 지적하고 있다.

보고서는 실태에 대한 인포그래픽과 관련한 동향을 소개하는 형식으로 구성되어있다. 이러한 실태를 통하여 관련한 영역(홈페이지 및 정보제공에 관한) 이 자체적으로 개선될 수 있도록 유도하고 있다.

보고서는 2016년부터 매년 발행되고 있으며, 2017년 접근성 조사에 따르면, 박물관 관람에 대한 의견은 다른 유형의 장소와 비교했을 때 상대적으로 높고, 상승하고 있다.

그러나 장애인이 아닌 사람에 비해 정기적인 방문이나 빈도가 낮은 박물관과 유적지에는 여전히 '장애 참여 격차'에 있음을 알 수 있다. 이 보고서에는 박물관이 온라인으로 제공하는 정보를 생성하거나 검토하도록 돕기 위한 지침이 포함되어 있다.

[그림 5-9] Museum access information Guidelines 조사결과

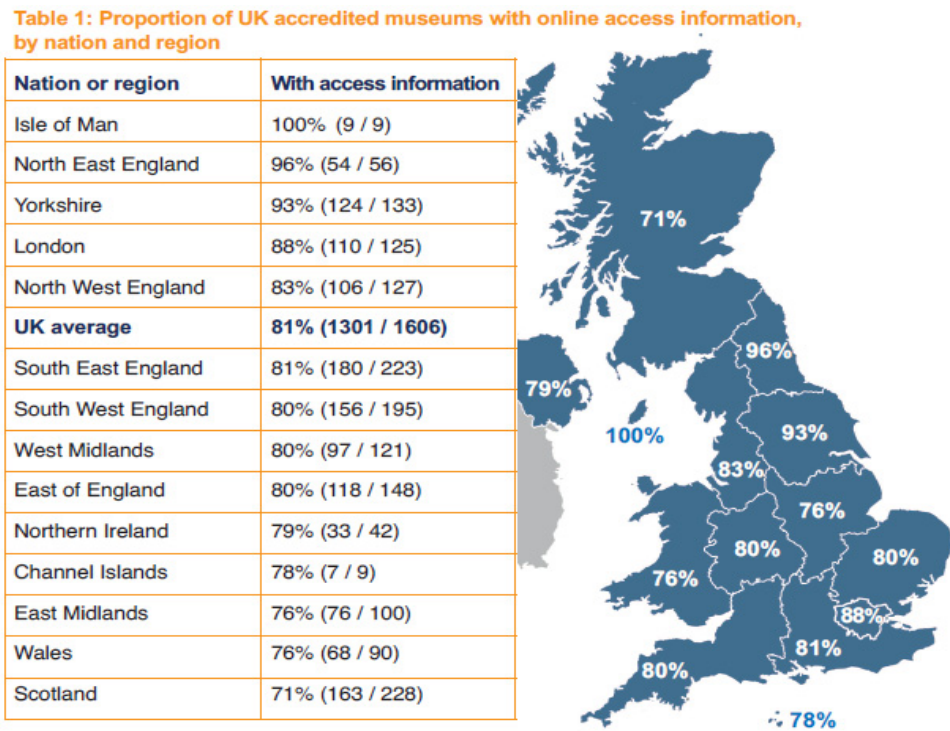

Table 2: Proportion of UK accredited museums with online access information, by type of museum

\begin{tabular}{|l|l|}
\hline Museum type & With access information \\
\hline Heritage sites & $98 \%(188 / 191)$ \\
\hline National museums & $97 \%(69 / 71)$ \\
\hline Local Authority museums & $81 \%(368 / 455)$ \\
\hline Independent museums & $77 \%(582 / 759)$ \\
\hline University museums & $77 \%(56 / 73)$ \\
\hline Military museums & $67 \%(38 / 57)$ \\
\hline
\end{tabular}

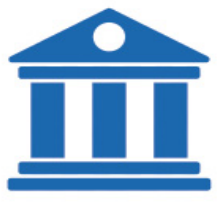

UK average $81 \%$ (1301/1606) 


\section{나. 장애인을 통한 정책 및 서비스 컨설팅}

장애인 서비스를 제대로 구현하기 위해서는 실제 이용자로서 장애인들의 의견을 적극적으로 수렴하고 컨설팅을 받는 것이 중요하다. 개별 장애인이 아닌 관련 기관 과 단체와의 협력을 통해서도 이뤄질 수 있다. 기존의 시설에 대한 개선 방안을 고 안하는 것만큼, 새로 지어지는 박물관·미술관의 경우 서비스를 개발 도입 전에 이들 의 검토는 매우 중요한 역할을 할 수 있다. 다음의 영역에서 장애인의 관점에서의 점검이 필요하다.

- 새로운 건물 또는 개보수가 실시되기 전, 새로운 개발 및 새로운 서비스가 도 입되기 전/ 접근성과 관련하여 내부 점검을 진행할 때, 프로그래밍, 정보 및 마케팅에 관한 장애인의 물리적, 종별 및 지적 접근성 등 종합적 검토/관련 정책 및 액션플랜 계획 시/직원 교육 및 역량 개발, 임원진들에게 장애 문제에 대한 인식 제공

다른 한편으로는 타 기관의 프로그램 사례 등을 공유하고 관련 논의를 통해서 프 로그램, 관련 담론들을 꾸준히 이어나가면서 장애인 접근성 강화에 대한 노력이 일 시적으로 끝나는 것이 아니라 지속가능하게 박물관 운영 전반에 영향을 미칠 수 있 는 방안을 모색할 수 있어야 한다. 이를 위해서 정부는 이를 독려하고 좋은 사례를 공유하는 워크숍, 인증 제도 등을 활용할 수 있다.

\section{참고 사례: 프랑스 문화부 ‘참여하는 박물관 償(Prix Osez le Musee)}

- '21세기박물관 정책'의 일환으로 2017년부터 시행된 본 공모는 경제적·사회적 취약 계층 대상 프로그램 을 운영하는 프랑스 박물관·미술관을 대상으로 프로그램의 내용과 운영 등을 평가하여 시상함: 장애인, 빈곤층 등 사회적·경제적 소외계층에 대한 박물관의 물리적·심리적 접근성 및 교육적 성격을 중심

- 다음의 요건 충족 여부를 심사 기준으로 함

1. 소외 계층을 위한 활동을 하는 사회단체와의 협업

2. 박물관 교육을 위한 다양한 수단 구비(방문자 안내 프로그램, 교육자료, 안내자료 등)

3. 관람객의 자율적 관람을 위한 다양한 물리적, 교육적 수단 구비(장애인의 접근성 향상을 위한 시설, 멀티 미디어, 디지털자료 등)

4. 협력단체와 그 대상을 위한 시행 안내서 발간, 배포

5. 협력단체와 그 대상을 위한 외부 기획 수립

6. 적정 관람 요금

7. 지역의 소외 방지 정책과 연계한 프로그램 수립

8. 일반 관객과 정책 대상이 되는 관객(소외계층)이 한데 어울릴 수 있는 방식의 프로그램 


\section{참고 사례: 프랑스 문화부 ‘참여하는 박물관 償(Prix Osez le Musee)}

- 시상은 크게 두 개의 그룹으로 구분하여 진행함: 프랑스 박물관(Musee de France로 인증된 전국 지자 체 단위의 박물관미술관)을 대상으로 하는 그룹, 이중 1 등에게는 50,000 유로(한화 약 7천 만원)의 상금 수여(공동수장자가 있을 경우 이 금액 내에서 상금 배분)

- 다른 그룹은 국립기관을 대상으로 하며, 이 그룹에서 선정된 박물관미술관의 경우, 참여하는 박물관 라벨 을 부여 받고 인증기관으로 선정됨

[그림 5-10] 행사 및 프로그램 포스터

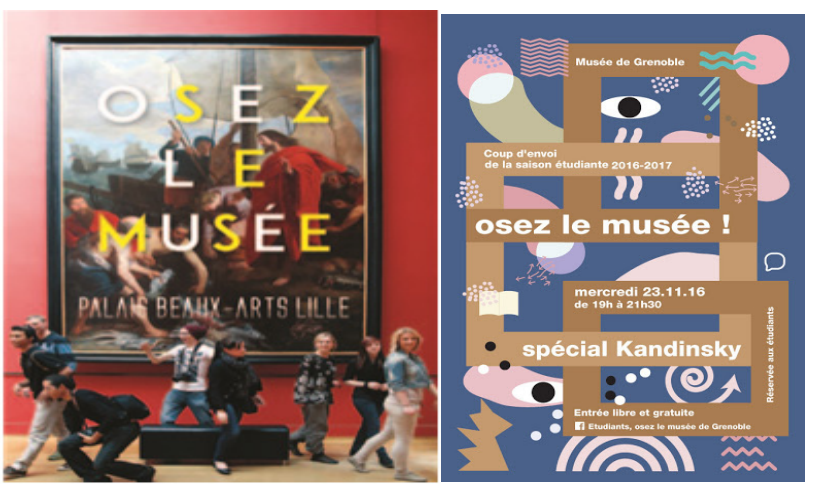

자료: 문화체육관광부 해외문화홍보원 해외정책동향(2018.03.21.) 내용 참고, 프랑스 문화부 홈페이지(2020.09 접속기준)

\section{2. 기관 종사자의 장애 감수성 함양34)}

본 연구를 통해서 면담한 장애인과 실무자들은 박물관·미술관 직원의 장애인에 대한 인식과 태도가 장애인의 관람 및 향유에 영향을 미치는 중요한 요소 중 하나로 꼽았다. 이와 같은 요소는 해외의 선행연구에서도 중요한 부분으로 인식되고 있다 (Australian Museum/National Museum of Australia, 2005).

요구조사에 참여한 장애인과 실무자들은 일반적으로 장애인에 대한 직원의 인식 과 태도를 좋지 않은 것으로 판단했다. 대부분 박물관.미술관이 관람자 친화적으로 변하고 있는 추세지만, 일반 장애 인식 훈련과 특정 장애에 대한 인식 훈련이 직원들 에게 필요함을 강조했다. 예를 들어, 관람객이 방문했을 때, 먼저 적극적으로 나와서

34) 본문의 경우 Australian Museum/National Museum of Australia(2005) 내용을 인용하되, 본 연구의 조사 및 분서 결과를 반영하여 작성함 
불편사항을 묻고, 사람들이 눈을 마주치는 훈련을 필요로 한다고 언급했는데, 이것 은 청각장애인들을 도울 뿐만 아니라, 모든 방문객박물관·미술관의 직원 상호작용을 향상시킬 수 있다. 다른 한편으로는 고객 지원을 담당하는 직원들은 시설에 대한 폭 넓은 이해를 하고 있어야한다, 어떤 시설물이 어떻게 배치되어있고 어떤 식으로 작 동하는 지에 대해서 직원 문의를 해도 잘 대답하기 힘들어한다는 의견이 있었다.

일반적으로 박물관·미술관 업무 중 다음의 영역에서 직원의 인식 수준이 장애 인의 경험에 영향을 미칠 수 있다(Australian Museum/National Museum of Australia, 2015).

- 마케팅, 홍보 및 미디어/티켓 판매/자원봉사자 및 가이드

- 큐레이터 및 교육 담당자/관리, 재무, 인력 및 수신

- 청소, 보안 및 건물 유지 관리/영업 보조원 또는 식당 및 카페 직원

\section{참고 사례: 단계별 직원교육의 내용과 방향}

\begin{tabular}{|c|c|}
\hline 단기 & $\begin{array}{l}\text { - 접근 인식 교육에는 물리적 접근, 서로 다른 의사소통 기법 및 지적 접근의 관점에서 서로 } \\
\text { 다른 청중의 요구를 이해하고, 적용되는 법률을 이해하며, 박물관을 보다 쉽게 접근하기 위한 } \\
\text { 실용적인 방법이 포함되어야 한다. } \\
\text { - 현장별 교육 제공 - 직원의 필요성(유급 및 자발적)과 박물관의 환경을 이해하는 사내에서 } \\
\text { 가장 잘 수행되는 교육(예: 시각장애인을 위한 투어에서 어떤 물체를 사용할 수 있는지, 가이 } \\
\text { 드가 특별한 도움이 필요한 어린이를 데려갈 수 있는지, 비상시에 도움을 줄 수 있는지) } \\
\text { - 지역 장애 및 전문가 접근 방법을 활용하여 일반 교육 실시 }\end{array}$ \\
\hline 중기 & $\begin{array}{l}\text { - 교육은 모든 직원에게 적합해야 하며, 서비스를 제공하거나 티켓팅 카운터에서 일하는 직원, } \\
\text { 해석 프로그램 및 행사를 설계하는 직원, 출판물 및 라벨 텍스트를 제작하는 직원, 전시 팀, } \\
\text { 인사 부서 및 정책 및 절차를 수립한 직원들에 대해 맞춤형 세션을 제공해야 한다. } \\
\text { - 가능한 경우 장애인을 위한 서비스, 특히 교육 서비스를 제공할 수 있는 특정 인력을 양성하 } \\
\text { 십시오. 그러나 모든 프로그램 전달 직원은 시청자의 인식 교육을 필요로 한다. }\end{array}$ \\
\hline 장기 & $\begin{array}{l}\text { - 조직 전체에 걸친 서비스 제공을 담당하는 액세스 조정자를 고용한다. 여기에는 해석적 서비 } \\
\text { 스와 자료의 개발, 직원 교육, 접근 가능한 홍보 및 정보 자료의 제작, 전시 디자인, 화장실, } \\
\text { 레스토랑, 축제 및 이벤트와 같은 서비스에 대한 접근, 접근 컨설턴트 및/또는 자문 패널의 } \\
\text { 조정, 파트너십 구성 및 유지 등이 모함된다. } \\
\text { - 교육, 공공 프로그램 및 방문자 서비스 영역 내에 위치해야 한다. 이것은 접근이 단순히 건 } \\
\text { 물, 전시 또는 장소에 대한 진입을 제공하는 것이 아니라 다른 학습 욕구에 대한 것이라는 } \\
\text { 것을 인식한다. }\end{array}$ \\
\hline
\end{tabular}

자료: Australian Museum/National Museum of Australia(2015) 
해당 보고서에서는 '훈련은 직원의 인식, 대응력, 지략력을 높인다'고 언급했는 데, 이는 접근성의 실질적인 향상으로 이어질 수 있고, 기관에서 임원진에게까지 이 에 대한 사항을 알리고 즉각적으로 개선할 수 있는 방식을 찾을 수 있도록 할 수 있고 보았다. 직원의 장애인에 대한 인식이 높아질 때, 장애인은 단체로 방문하여 전체적인 박물관·미술관의 일상적인 관람환경에서 별도로 구분되어야한다는 인식 으로부터 개인방문객으로서의 장애인에 대한 존중과 배려가 있는 일상적인 관람환 경이 형성될 수 있다.

\section{3. 사회 통합적 관점에서 기관 운영 내 장애인 참여 고려}

상기된 다양한 장애인 친화적인 운영환경을 만들어 가는데 가장 빠르고 정확한 방법은 박물관.미술관 운영에 장애인을 참여시키는 것이다. 장애인이 필요로 하는 서비스와 여건에 대하여 공감할 수 있고 장애인이 가지고 있는 네트워크를 연결할 수 있는 중간 매개자 역할을 수행할 수 있다.

앞서도 언급한 바와 같이 단기적으로는 장애인 대면 서비스에 대하여 장애인을 직접 고용하여 서비스를 제공하는 방식이 있다. 이러한 방식은 장애인 서비스를 제 공하는데 효과적이다. 하지만 서비스와 프로그램 기획에 참여하는 것은 쉽지 않은 일이다. 연구에 참여한 전문가와 실무자, 장애인들은 학교와 병원에 사회복지사가 이제는 필수 고용인력이 된 것과 마찬가지로 일정 규모 이상의 기관에서는 문화 분 야의 사회복지사 역할을 담당하는 전담 직원 배치를 고려해 봐야 한다고 조언했다. 장애인을 대상으로 하는 프로그램이 박물관-미술관의 어떠한 부서에 국한 된 것 이 아니기 때문에 총괄적으로 코디네이션을 해야하는 부분을 담당하여 서비스를 기 획하고 조율하며 관리하는 사람이 필요하다고 강조하였다. 이와 같은 직무와 인력 의 필요성은 교육 프로그램을 전담하는 특수교육 전공의 교육사에도 마찬가지다. 장애아동들이 가지고 있는 장애가 복합적인 양상이고 장애아동들은 복지관점과 함 께 교육 관점에서 다뤄져야 한다고 보았다. 이를 위해서 특수교육을 전공한 교육담 당자의 역할이 중요하다.

국내에서는 장애인 고용의무제도를 시행하고 있지만, 예를 들어 박물관·미술관에 
고용되는 주요 직군인 학예사와 같은 전문직군의 경우 고학력의 다수의 경력을 요 구하는 실정이어서 실질적으로 직무에 적합한 장애인을 찾는 것은 쉽지 않을 수 있 다. 이러한 상황은 해외의 경우도 마찬가지다, 영국의 장애인 박물관·도서관, 아카 이브 가이드라인인 「Employment at Every Level_(MLA,2005)에서도 이러한 내 용들을 설명하고 있는데, 박물관·미술관의 모든 영역에서 장애인 고용이 될 수 있는 환경을 만들어야한다고 보고 있다. 이 가이드라인에 따르면, 장애가 없는 직원들은 장애인 직원들이 있을 때 직장이 개선된다는 것을 종종 발견하며, 당신은 방문자와 고객들에게 더 나은 서비스를 제공할 수 있다는 것을 발견할 수 있다고 설명한다.

또한 이 가이드라인은 본 연구의 주제인 박물관·미술관에서의 장애인 접근성이 강화되기 위해서는 조직이 장애인에 대한 태도를 변화할 필요가 있는데, 이에 대한 태도를 바꾸는 가장 좋은 방법은 장애인들과의 접촉을 늘리는 것이라고 강조했다. 이것은 장애인들이 사회적으로, 무엇보다도 취업을 통해, 다른 사람들이 그들과 상 호 작용해야 할 때 - 서비스를 요청하고, 정보를 얻거나, 자신의 임무를 수행하기 위해서 - 비로소 자연스럽게 만들어진다고 이야기하고 있다.

\section{참고사례: 영국 ACE(2017), Making A Shift Report}

- 장애인들이 문화예술분야 고용에 있어 어떠한 환경과 맥락에서 일하게 되며, 어떠한 장벽과 지원이 가능한 그룹을 만날 수 있는지, 어떤 과정을 통해서 고용현장에 참여할 수 있는지에 대한 과정과 업무 의 프로세스 등을 설명하고 있음

- 영국은 이미 2000년대 초반부터 장애인과 관련한 문화예술분야에서의 가이드라인이 분야별로 세분 화되었고, 장애인 문화예술분야 실태조사 및 정책 모니터링이 지속적으로 이뤄져왔음. 이에 문화예술 분야에서의 장애인의 고용의 장벽과 이를 해소할 수 있도록 돕는 가이드라인이 발간 될 수 있었음 

장애인 접근성 강화를 위한 박물관-미술관 가이드라인 수립 방향 연구

\section{제6장}

결론 및 제언 



\section{제1절 결론}

"Museum have unique potential for addressing and fostering cultural understanding interdisciplinary ways"

International Council of Museums, 2005

21세기의 박물관.미술관은 지난 세기의 그것과는 다른 역할과 기능 속에서 변화 하고 확장되고 있다. 실질적으로 이 변화는 박물관-미술관 내부의 문제로 발현되는 것이라고 보기 어렵다. 빠르게 변화하는 사회의 외적 영향력이 그 어느 때보다 더욱 더 중요해지고 있으며, 그 영향력을 통해서 박물관·미술관은 진화하고 있다. 최근 논의가 진행되고 있는 새로운 박물관의 정의 역시 이러한 사회의 변화에 박물관·미 술관이 좀 더 능동적으로 대응해야 함을 강조하고 있다. 이러한 상황 속에서 박물 관·미술관은 그 어느 때보다 관람자의 목소리에 귀 기울이고 이들의 관심사에 집중 하고자 노력하고 있다.

이에 본 연구는 '장애인을 위한' 무언가를 만들기 위한 관점보다는 박물관·미술관 이 좀 더 '다양한 관람객'들에게 좀 더 나은 관람환경을 제공할 수 있는 방향을 고민 하는 데에서부터 출발하고자 했다. '다양한 관람객'은 우리나라 「문화기본법」 제4조 의 '성별, 종교, 인종, 세대, 지역, 정치적 견해, 사회적 신분, 경제적 지위나 신체적 조건 등'에 차별받지 않은 모든 국민을 의미한다. 박물관·미술관은 전문적인 영역에 대한 특수한 서비스를 제공하기 때문에 '다양한 관람객'을 맞이하는 데 필요한 준비 사항이 별도로 마련되어야 하며, 준비의 일환으로서 본 연구는 '장애인을 위한 박물 관·미술관 가이드라인'의 수립 방향을 제시하고자 하였다.

이는 좀 더 넓은 의미에서 박물관.미술관의 활동과 밀접하게 관계되는 '문화향유 정책' 차원에서 이해했을 때 향유자로서의 장애인이 어떤 차별도 받지 아니하고 문 
화를 누릴 수 있는 권리를 보장하는 차원으로 볼 수 있다. 현실적으로 현재의 박물 관·미술관 환경에서의 장애인은 문화복지정책 차원의 '소외계층' 으로 분리되어있는 실정이다. 소외계층에 대한 프로그램은 개별 박물관.미술관에서 의무적인 영역이지 만 동시에 '주목하지 않는' 소수를 위한 프로그램으로써 활성화되기 어려웠다. 즉, '장애인'을 소외계층의 영역에 두고 접근을 했을 때 이와 같은 가이드라인은 '소수' 의 영역이 될 수밖에 없다. 하지만 보편적인 문화향유의 확대와 질적 개선의 차원에 서 장애인을 향유자의 대상으로 본다면 신체적 다름을 배려하여 소외당하는 사람 없도록 하는 당연한 조치로서 '보편적 관점'에서 장애인에 대한 접근을 재정립할 수 있을 것이다.

「장애인복지법」을 비롯한 '장애인'을 주체로 하는 법령들이 체계적으로 갖춰지고 관련 국가종합계획에 따라 장애인의 '문화향유' 확산에 노력이 많았음에도 불구하 고, 조사결과에서도 볼 수 있는 바와 같이 박물관-미술관 현장에서의 장애인 관련 서비스가 확대되지 못하고 있는 상황은 이러한 문제에서 기인한다고 볼 수 있다. 장애인을 주체로 보고 있는 복지나 특수교육영역과는 달리 문화정책(또는 문화향유 정책) 내에서 장애인은 여전히 '소외계층'으로서 소수를 위한 별도의 사업, 프로그 램에 머물고 있으며, 조사결과에서도 살펴본 바와 같이 그마저도 수요가 많지 않다 는 이유로 활성화되지 못하고 있다. 서비스 요구조사에서 제시된 장애인을 중심으 로 '범부처 간 협력'을 강조하고 박물관·미술관의 공공성 실현의 중요 사업으로서 인력과 예산 배정을 '의무화' 해야 하는 방안은 문화정책 내에서의 '장애인'에 대한 접근이 변화되지 않고서는 반영되기 어렵다.

이에 본 연구에서 제시하고 있는 장애인 접근성 강화를 위한 가이드라인 방향은 장애인에 대한 접근과 인식의 개선을 전제로 삼고 이를 기본 원칙으로 한다.

장애인의 사회적 모델은 장애인 정책뿐만 아니라 박물관·미술관 분야를 포괄하는 문화정책에서도 적용되어야 하며, 이러한 인식을 통하여 장애인의 문화예술 참여와 문화권 보장을 확대하려는 노력이 필요하다. 이를 실현하기 위해서는 장애인의 특 수성을 보편성과 조화시키려는 노력이 필요하며 거기에 가장 우선이 되어야 하는 것이 바로 인클루시브 디지인과 유니버설디자인이다. 궁극적으로 이러한 노력은 박 물관·미술관의 공공성 실현하는 중요한 원천이 되며, 장애인이 차별받지 않은 사회 를 구현하는데 기여할 것이다. 상기의 기본원칙 하에 〈표 6-1〉과 같이 제시된 박물 
관.미술관 가이드라인 수립의 원칙을 통하여, 물리적 접근성의 장벽을 개선하고, 박 물관·미술관 서비스와 정보, 지식에 대한 접근성을 강화를 통하여 장애인의 문화적 접근성 확대의 기여할 수 있도록 해야 한다.

〈표 6-1〉 장애인 접근성 강화를 위한 가이드라인 기본원칙과 수립방향

\begin{tabular}{|c|}
\hline 기본원칙 \\
\hline \\
장애의 사회적 \\
모델과 장애인 \\
문화예술 참여 \\
\\
문화시설의 \\
특수서비스와 \\
장애인을 고려한 \\
인클루시브 \\
디자인 적용 \\
\hline 박물관.미술관의 \\
사회적 포용과 \\
공공성의 실현 \\
\hline
\end{tabular}

\begin{tabular}{|c|c|c|}
\hline \multicolumn{2}{|r|}{ 가이드라인 방향 } & \multirow{2}{*}{ 세부 방향 } \\
\hline 대분류 & 내용 & \\
\hline \multirow{2}{*}{$\begin{array}{l}\text { 접근성이 } \\
\text { 향상된 } \\
\text { 전시관람환경 } \\
\text { 조성 }\end{array}$} & \multirow{2}{*}{$\begin{array}{l}\text { 접근성이 향상된 전시’는 전시실 자 } \\
\text { 체를 장애인을 염두에 두고 설계하 } \\
\text { 어 ‘모든 장애인이 불편 없이 전시에 } \\
\text { 접근할 수 있는’ 환경으로 이러한 환 } \\
\text { 경 조성을 위해 필요한 제반 사항을 } \\
\text { 다룸 }\end{array}$} & $\begin{array}{c}\text { 접근성 향상을 위한 전시공간 } \\
\text { 연출 }\end{array}$ \\
\hline & & $\begin{array}{c}\text { 전시 기획에서의 장애인 관련 } \\
\text { 주제의 활용 }\end{array}$ \\
\hline \multirow{3}{*}{$\begin{array}{l}\text { 장애인 친화적 } \\
\text { 서비스 제공 }\end{array}$} & \multirow{3}{*}{$\begin{array}{l}\text { 장애인이 박물관에 도착에서부터 집 } \\
\text { 으로 돌아갈때까지 경험하게 되는 } \\
\text { 것들을 서비스라고 전제하고 이러한 } \\
\text { 서비스 이용에 대한 사항을 다룸 }\end{array}$} & $\begin{array}{l}\text { 장애인 방문 여정에 대한 } \\
\text { 종합적 고려와 서비스 제공 }\end{array}$ \\
\hline & & 맞춤형 현장 서비스 제공 \\
\hline & & $\begin{array}{c}\text { 장애인 유형별 웹 접근성 } \\
\text { 고려 설계 }\end{array}$ \\
\hline \multirow{3}{*}{$\begin{array}{l}\text { 포용적 관점이 } \\
\text { 반영된 } \\
\text { 프로그램 운영 }\end{array}$} & \multirow{3}{*}{$\begin{array}{l}\text { 박물관을 찾는 실질적 목적으로서 } \\
\text { 다양한 프로그램을 이용할 수 있도 } \\
\text { 록 장애인을 고려한 프로그램 설계 } \\
\text { 의 방향 제시 }\end{array}$} & $\begin{array}{c}\text { 교육과정 연계 특수교육대상자 } \\
\text { 프로그램 개발 }\end{array}$ \\
\hline & & $\begin{array}{c}\text { 커뮤니티 연계를 위한 } \\
\text { 아웃리치 활동 }\end{array}$ \\
\hline & & $\begin{array}{c}\text { 고령친화(Age-Friendly) } \\
\text { 프로그램 기획 }\end{array}$ \\
\hline \multirow{3}{*}{$\begin{array}{l}\text { 장애인 문화권 } \\
\text { 보장을 위한 } \\
\text { 환경 마련 }\end{array}$} & \multirow{3}{*}{$\begin{array}{l}\text { 장애인을 고려한 서비스 설계를 위 } \\
\text { 해서 필요한 기관의 경영 및 운영 차 } \\
\text { 원의 환경 조성에 관한 방향성 제시 }\end{array}$} & $\begin{array}{c}\text { 기관 내의 운영정책에 } \\
\text { 장애인서비스에 대한 필수 고려 }\end{array}$ \\
\hline & & $\begin{array}{c}\text { 기관 종사자의 } \\
\text { 장애 감수성 함양 }\end{array}$ \\
\hline & & $\begin{array}{l}\text { 사회 통합적 관점에서 기관 } \\
\text { 운영 내 장애인 참여 고려 }\end{array}$ \\
\hline
\end{tabular}




\section{제2절 제언}

본 연구는 문화시설 중 박물관.미술관 환경에 특화된 장애인 가이드라인에 관한 선행연구를 분석하고, 현재 국공립 박물관.미술관의 장애인 관련 사업 운영현황과 서비스 요구사항 등을 파악하여 가이드라인 수립을 위한 방향을 도출하는 최초의 시도로서 그 의의가 있다. 제시된 가이드라인 수립 방향은 박물관-미술관 환경에서 장애인을 위한 서비스, 프로그램, 환경을 만드는데 필요한 원칙들이다. 이러한 원칙 을 기초로 하여, 본격적인 가이드라인 수립이 후속적으로 반드시 이뤄져야 한다. 특 히 본 연구에서는 장애 유형별 맞춤형 서비스가 필요하다고 보는 원칙과 관련 대표 사례를 제시하는 데에 그치고 있어 장애인 유형별 접근성 개선 방식, 서비스 제안의 경우 세부적으로 다뤄지지 못한 한계를 갖는다. 이는 후속연구와 가이드라인 수립 을 통하여 유형별 장애인들의 대표성을 고려한 표본을 설정하고(페르소나 접근 등) 세부 서비스를 UX 분석 및 설계를 통하여 본격적으로 다뤄야 할 영역이다.

국내 문화시설 중에 유일하게 도서관 분야의 경우 2000년대 초반부터 장애인 서 비스에 관한 다양한 정책연구와 가이드라인, 매뉴얼 개발 등이 이뤄져 현재는 도서 관 장애인 서비스에 대한 정기적 조사, 모니터링 등이 꾸준하게 이뤄지고 있다. 차 후 박물관.미술관 분야의 가이드라인 수립과정에서 〈표 6-2〉와 같이 도서관 분야 에서 진행한 세부적인 정책연구의 주제와 가이드라인 및 매뉴얼에 대한 과정을 참 고할 수 있을 것이다.

후속적으로 이뤄질 본격적인 가이드라인 수립에 있어서 가장 우선되어야할 것은 현재의 실태에 대한 파악이다. 본 연구에서 조사된 현황의 경우 국공립 박물관.미술 관 중 연평균 관람객 5 만명 이상의 기관을 대상으로 진행되어 국내 박물관.미술관에 대한 전체 현황을 유추하는 데 한계가 있다. 또한, 국공립을 대상으로 진행하여, 사 립 주체의 중소 박물관.미술관의 상황 파악하기 어렵다. 국내 박물관-미술관의 절반 
이상을 차지하고 있는 사립 관의 경우35) 기관 운영비를 자체적으로 조달하고 규모 가 크지 않은 상황에서 관련한 사업과 프로그램이 매우 미비할 것으로 예측할 수 있 다. 이에 대한 정확한 실태를 파악하고 정책적인 지원 등을 마련할 필요가 있다.

〈표 6-2〉 국내 국립 도서관 장애인 관련 서비스관련 정책 연구 보고서

\begin{tabular}{c|l|c}
\hline 연도 & \multicolumn{1}{|c|}{ 연구보고서 } & 발주처 \\
\hline 2007 & 도서관의 장애인 서비스 기준 및 지침 제정 연구 & 국립중앙도서관 \\
\hline 2007 & 국립장애인도서관 지원센터 장애인 디지털정보 서비스 연구 & 국립중앙도서관 \\
\hline 2008 & 도서관 장애인 서비스 협력망 구축 및 운영 & 국립중앙도서관 \\
\hline 2009 & 공공도서관 장애인 서비스 자원봉사자 활동·관리 매뉴얼 개발 연구 & 국립중앙도서관 \\
\hline 2010 & 장애인도서관 서비스 평가지표 및 기준연구 & $\begin{array}{c}\text { 국립중앙도서관- } \\
\text { 국립장애인도서관지원센터 }\end{array}$ \\
\hline 2011 & 장애 유형별 도서관 장애인 서비스 홍보전략 방안 연구 & 국립중앙도서관 \\
\hline 2012 & $\begin{array}{l}\text { 지적·자페성 장애인을 위한 도서관서비스 해외사례조사 및 } \\
\text { 국내 적용모델 개발 }\end{array}$ & $\begin{array}{c}\text { 국립중앙도서관- } \\
\text { 국립장애인도서관 }\end{array}$ \\
\hline 2014 & 도서관장애인서비스의 이해 교육교재 개발 & $\begin{array}{c}\text { 국립중앙도서관- } \\
\text { 국립장애인도서관 }\end{array}$ \\
\hline 2016 & 도서관 장애인서비스 제고를 위한 기준 및 매뉴얼 개선 연구 & 국립장애인도서관 \\
\hline 2018 & 도서관 장애인서비스 운영자 역량강화를 위한 교육과정 개발 & $\begin{array}{c}\text { 국립중앙도서관- } \\
\text { 국립장애인도서관 }\end{array}$ \\
\hline $2007 ~$ & 더서관장애인서비스현황조사 & $\begin{array}{c}\text { 국립중앙도서관- } \\
\text { 국립장애인도서관 }\end{array}$ \\
\hline (매2년 마다)
\end{tabular}

장애인편의시설 및 특수아동의 교육 환경 등과 관련하여 복지부와 교육부가 중점 적으로 진행하고 있는 사업과는 별개로 문화체육관광부 차원에서는 박물관·미술관 인증제도의 시행과 함께 장애인 프로그램 및 서비스에 대한 기관들의 현황을 파악 하고 이를 박물관·미술관의 주요한 기능으로 인식할 수 있도록 지표와 관련한 모범 사례 등을 공유할 수 있도록 노력해야 한다. 살펴본 바와 같이, 박물관·미술관의 환 경에서 장애인은 아직 '소외계층' 으로서 의무적인 프로그램을 통해서 다뤼지는 소 수의 대상이다. 이러한 인식의 전환을 끌어낼 수 있는 제도적인 장치로서 박물관·미 술관 평가 인증제와 공립박물관 건립 사전 타당성 평가 등을 적극적으로 활용해야 할 것이다. 지표의 목적은 진행 정도 측정, 전략기획 촉진, 의사결정을 위한 정보제

35) 2018년 전국문화기반시설 총람 기준, 사립 박물관은 전체박물관 중 $42 \%$, 사립미술관은 전체 미술관중 $67 \%$ 
공, 책무성 강화, 대중의 관심 고취 및 홍보/교육 등으로 장애인에 대한 지표를 강 화하고 이를 통하여 박물관 미술관이 추구해야 하는 공공성에 대하여 재검토할 수 있도록 해야 한다.

또한 인력과 예산의 투입을 통하여 장애인 관련 사업의 지속성을 담보할 수 있어 야 한다. 장애인 사업이 일반 회계 내의 교육프로그램 예산과 함께 사용될 때, 상대 적으로 소수를 대상으로 한다는 이유로 프로그램 운영이 원활하지 않을 수 있다. 교육프로그램의 일정 부분을 쿼터 형태로 지정하여, 의무화하는 방식도 고민해볼 수 있다. 이때 프로그램 운영자의 장애에 대한 전문성을 담보할 수 있는 장치가 함 께 수반되어야 할 것이다. 2014년부터 2017년까지 기재부와 문화재청이 진행한 낙 후지역 어린이들 대상의 “찾아가는 박물관" 교육프로그램 운영의 경우, 박물관·미술 관의 자체 운영예산으로 운영하기 힘든 아웃리치 프로그램에 대한 범 부처 간 연계 를 통하여 진행된 사례로 볼 수 있다. 장애인이라는 '대상'을 중심으로 범부처 간의 연계 사업 기획 등을 통하여 예산과 인력 수급의 한계를 보완할 수 있다.

서두의 인용구(International Council of Museums, 2005)에서 언급한 바와 같이 박물관·미술관은 다학제적인 방식으로 (넓은 의미의) 문화와 그 다양성을 이해 할 수 있는 사회의 유일한 창구이다. 사회를 구성하는 다양한 사람들의 문화를 이해 하고, 그들과 함께 생각을 공유하여 인식을 확장할 수 있는 공간으로 박물관·미술관 의 역할을 명시한 것으로 볼 수 있다. 이러한 박물관-미술관의 모습은 이전 시대와 는 다른 것으로, 현재의 우리에게 새롭게 주어진 임무라고도 할 수 있다. 사회적 편 견과 차별을 막을 수 있는 것은 우선 타인에 대한 문화적 이해를 통해서 일 것이다. 이에 박물관·미술관이 장애인과 비장애인이 공존하는 사회를 구현하기 위한 인식 전환변화의 원천으로서 중요한 사회적 책무를 가질 수 있으며, 본 연구가 박물관.미 술관의 사회적 책무에 대한 작은 시작이 될 수 있기를 기대한다. 


\section{참고문헌}

\section{[정책보고서]}

- 관계부처 합동(2018), 〈제5차 장애인정책종합계획〉

- 국가인권위원회(2011), 「장애인차별금지법상 인적 편의제공에 관한 연구」

- 국가인권위원회(2019), 「장애인 관광활동 보장을 위한 정당한 편의제공에 관한 연구」

- 국립고궁박물관(2011), 「시각장애아동 대상 교육프로그램 개발 연구」

- 국립고궁박물관(2013), 「조선 왕실문화 활용 예술치료 프로그램 개발 」

- 국립중앙도서관(2007), 「도서관 장애인 서비스 기준 및 지침 제정 연구」

- 국립현대미술관(2012), 「특수아동을 위한 미술관교육 활성화 방안 연구-국립현대미 술관 교육 프로그램을 중심으로」

- 국립한글박물관(2018), 「국립한글박물관 장애인대상 교육 프로그램 개발 연구보고서」

- 국립재활원(2018), 「장애인과 비장애인의 생애주기별 건강특성 비교를 통한 장애인 의 노화 특성 연구」

- 교육부, 「2019 특수교육통계」

- 문화체육관광부(2012), 「유니버설디자인 실태분석 및 문화적 적용방안 연구」

• 문화체육관광부(2013), 「유니버설디자인 가이드라인 연구」

- 문화체육관광부, 한국장애인문화예술원(2018), 「장애인 문화예술활동 실태조사 기초연구」

- 문화체육관광부, 한국장애인문화예술원(2019), 「2018 장애인 문화예술활동 실태조 사 및 분석연구」

- 문화체육관광부(2019), 〈박물관 및 미술관 진흥 중장기 계획(2019 2023)〉

- 문화체육관광부(2019a), 「무장애 관광환경 조성계획 수립 연구」

- 문화체육관광부(2019b), 「2019 전국문화기반시설총람」

- 문화체육관광부(2019c), 「국공립 박물관·미술관 무료관람정책 성과 분석 및 개선방 안 연구」

- 보건복지부, 한국장애인개발원(2011), 「공공기관(읍면동사무소, 공공도서관, 문화공 연장 등)에서의 장애인 접근권 향상을 위한 연구」 
• 보건복지부(2020), 「2019년 등록장애인 현황」

- 보건복지부, 한국장애인개발원(2019), 「2018 장애인 편의시설 실태 전수조사」

- 보건복지부, 한국장애인개발원(2019), 「Universal Design 적용을 고려한 장애물 없는 생활환경 인증 상세표준도」

- 아시아문화원(2019), 「아시아문화원 장애인 응대 매뉴얼」

- 한국장애인개발원(2019), 「2019 장애통계연보」

- 한국관광공사(2015), 「장애물없는 관광 시설 및 서비스 가이드라인 구축」

- 김현경(2017a), ‘'고령 친화(Ageing-friendly)' 박물관의 역할과 기능 탐색」, 한국 문화관광연구원

- 김현경(2017b), 「박물관의 사회적 기능 확대 방안 연구-포용적 박물관을 중심으로」, 한국문화관광연구원

- 전병태(2010), 「공공 문화예술기관 장애인 서비스 개선 방안」, 한국문화관광연구원

- 류정아·김현경(2016), 「스마트융합 환경에서의 박물관·미술관 기능 개선의 방향 연 구」, 한국문화관광연구원

- 최보연·조현성(2020), 「예술향유정책 분석 및 방향 연구」, 한국문화관광연구원

- 해외문화홍보원(2018), "프랑스 문화부, 문화적 소외 방지를 위한 미술관 정책 참여 하는박물관 상” 해외정책동향(2018.03.21.)

- DCMS(1999), 「Arts and Sport; Policy Action Team 10; A report to the Social Exclusion Unit」

- Meeting of Ministers(2018), Research Overview-Arts and DIsability in Austraila

\section{[단행본]}

- C.Kudlick, E. M. Luby(2019), "Access as activism: Bringing the museum to the people" in Museum Activism, R.R. Janes \& R. Sandell(ed.)

- Fondation de France et ICOM(1991), 『Des Musees ouverts a tous les sen $\mathrm{s}_{\Perp}$, Paris: Fondation de France

- Lois H. Silverman(2010), 『The Social work of Museums』. London: Routledge

- P. Bourdieu.(1966), 『L'amour de l'art, Les musees d'art et leur public』 Paris: Collection Le sens commun

- Playforth, S. (2003). 「Consulting Disabled People, in MLA」, Disability Portfolio.

- R.R. Janes \& R. Sandell(ed.)(2019), 『Museum Activism』, London: Routledge 
- R. Sandell \& J. Dodd,. Alison Coles (ed.) (1998), 『Building bridges: guidance for museums and galleries on developing new audiences』Museums \& Galleries Commission

- R. Sandell(2006), "Museum, Prejudice and the reframing of difference , London: Routledge

- R. Sandell \& J. Dodd, R. Garland-Thomson(ed.)(2010), 『Re-presenting disability: Activism and agency in the museum』, London: Routledge

- 니나사이먼 著, 이홍관 譯(2018), 『연관성의 예술』, 서울: 연암서가

- 다니엘 지로디, 앙리뷔이예著, 김혜경 譯(1996), 『미술관박물관이란 무엇인가』, 서울: 화산문화

- 백남준아트센터(2018), 『미래 미술관: 공공에서 공유로』, NIP 리더 8호

- 클래어 비숍 외 著, 김해주 외 譯 (2019), 『래디컬 뮤지엄』, 서울: 현실문화

\section{[학술논문 및 article]}

- 박수진·최윤정(2019), "서비스디자인 방법론을 통한 발달장애인 복지서비스 개선 방 안”. Archives of Design Research, 32(4), 85-95

- 안성락·고영준(2013), "유니버설디자인 관점에서의 문화시설접근성과 위생시설에 관한 연구”, Journal Packaging Culture Design Research Korea Institute of Packaging Culture Design Vol. 352013

- 윤은영·이화세(2016), “국내 미술관 사이트의 웹 접근성 평가", Journal of Korea Multimedia Society Vol. 19, No. 10, October 2016(pp. 1816-1828)

- 이민경(2018), "장애인의 사회활동 및 문화-여가 활동 실태와 정책과제” 「이달의 초 점」no.263 (2018.09), 한국보건사회연구원

- 이대식(2020.03), “한국 특수교육의 현황과 발전방향”, 교육을 바꾸는 사람들 웹진

- 임진이·이정민(2004.7), “포스트모더니즘 관점에서의 유니버설디자인의 이해" 「기 초조형학연구」제8권 제3호 449-457

- 정종은(2019), “협업은 피할 수 없고, 융합은 필수적이다" 「웹진 이음」

- Kojiro Hirose(2013), Research on Methods of “Touching the World” - The Aim of the Exhibit Area of Tactile Learning in Japan's National Museum of Ethnology Kojiro

- Kim, T. (2015). Characteristics of Inclusive Design and Its Meaning in the Future Society. Archives of Design Research, 28(2), 137-151 



\section{ABSTRACT}

\section{A Study on Establishing the Guideline of Museums and Art Galleries for Accessibility of Disabled Persons}

\footnotetext{
Museums and art galleries are the only means through which culture and diversity can be understood in a multidisciplinary way. The role of museums and art galleries can be specified as a space to understand the cultures of a variety of people constituting society, share thoughts with them, and expand perceptions. The images in the museums and art galleries are different from those in the previous times, and can provide a new mission for people living in the contemporary era. Prevention of social bias and discrimination can be done through cultural understanding of others above all. This study started from the point of view that museums and art galleries can have an important social responsibility as the social perception shifts to one where disabled people and normal people can co-exist.

To this end, this study examined the discussions of access, which have been dealt with from the facility aspect in the domestic policy of museums and art galleries and from the perspective of disabled people's cultural enjoyment. Greater restrictions in the physical accessibility of disabled people exist compared to normal people; therefore, Korea's legal system involving disabled people stipulates a solution to physical barriers and encourages people to abide by the laws. Cultural enjoyment activities need to be handled in a complex way combined with accessibility to information and services, as well as with a solution to physical barriers as a basic precondition. From the lexical meaning that enjoyment has, it is not enough to only deliver physical accessibility
} 
improvement to make people enjoy and create cultures for themselves. This applies to both disabled people and normal people and requires the consideration of diverse factors.

From this perspective, this study aims to seek a direction in which disabled people's cultural enjoyment activities can be carried out in a better way than the present under the museum and art gallery environment. Given that the details of guidelines can encompass what museums and art galleries should do to concretely improve access barriers, this study presents principles and a direction on how the activities of museums and art galleries should be offered to disabled people.

The guidelines are instructions that present a task (a situation) to head towards a purposive direction. For guideline establishment, the current situation of disabled people's accessibility should be preferentially understood. To this end, Chapter 2 looks at the meaning of disabled people's accessibility in museums and art galleries, namely what barriers disabled people encounter in museums and art galleries and what legal and institutional efforts need to be carried out to remove the barriers.

Chapter 3 analyzes foreign museum and art gallery guideline examples related to disabled people's accessibility. Due to the absence of previous domestic studies, the scopes and types, centered on foreign data, are examined. Chapter 4 presents the services offered to disabled people in domestic museums and art galleries and draws the investigation and analysis results based on the demands of the disabled people as users and the grounds of relevant sector workers to establish the guideline establishment direction. What is important in the principles and directions centered on users is how they tour around museums and art galleries, rather than how often (long) they tour around them. To understand this, various data related to visitors to museums and art galleries should be accumulated. However, it is difficult to collect data that are helpful for understanding the museum and art gallery visitors' needs, except for gathering the number of visitors present. This study looked into the demands of disabled people as users, as well as data on services for disabled people in museums 
and art galleries through a survey. Based on the information, Chapter 5 presents a direction for museum and art gallery guideline establishment.

In this report, basic principles to consolidate disabled people's accessibility were presented, along with the guideline direction for detailed domains. The basic principles offered a comprehensive direction on disabled people's accessibility consolidation and dealt with details of guidelines in each domain. The details were presented, centering on the principles in each domain, whereas domestic and foreign guidelines and program operation examples were offered as a reference to produce future concrete guidelines.

As for the basic principles, a social model, inclusive/universal designs, and the social responsibilities of museums and art galleries were considered as follows:

- Disability's social model and disabled people's participation in cultures and arts

- Inclusive design application in consideration of cultural facilities' special services and disabled people

- Realization of social inclusion and publicness of museums and art galleries

Under the above basic principles, the direction of the guideline establishment was set as follows:

- To shape the exhibition viewing environment with improved accessibility

- To create a program operation reflecting an inclusive perspective

- To offering disabled people-friendly services

- To prepare an environment that guarantees disabled people's cultural rights

The guideline direction is classified into detailed directions and the details are presented below: 


\begin{tabular}{|c|c|c|}
\hline Guideline Direction & \multicolumn{2}{|c|}{ Detailed Direction } \\
\hline \multirow{6}{*}{$\begin{array}{l}\text { Shaping the } \\
\text { exhibition viewing } \\
\text { environment with } \\
\text { improved accessibility }\end{array}$} & \multirow{5}{*}{$\begin{array}{l}\text { Presentation of exhibition spaces } \\
\text { for accessibility improvement }\end{array}$} & Exhibition space \\
\hline & & $\begin{array}{l}\text { Audiovisual and interactive } \\
\text { experience }\end{array}$ \\
\hline & & Exhibition panel \\
\hline & & Lighting level \\
\hline & & Height of works \\
\hline & \multicolumn{2}{|c|}{$\begin{array}{l}\text { Utilization of disabled people-related themes in exhibition } \\
\text { planning }\end{array}$} \\
\hline \multirow{7}{*}{$\begin{array}{l}\text { Program operation } \\
\text { reflecting an inclusive } \\
\text { perspective }\end{array}$} & \multirow{5}{*}{$\begin{array}{l}\text { Comprehensive consideration on } \\
\text { disabled people's visit itinerary } \\
\text { and service offering }\end{array}$} & Visitation and stay hours \\
\hline & & Admission fees \\
\hline & & Transportation means \\
\hline & & Convenience facilities \\
\hline & & Guide-accompanied tour \\
\hline & \multicolumn{2}{|l|}{ Offering customized onsite services } \\
\hline & \multicolumn{2}{|c|}{ Design considering Web accessibility by disabled people type } \\
\hline \multirow{3}{*}{$\begin{array}{l}\text { Offering disabled } \\
\text { people-friendly } \\
\text { services }\end{array}$} & \multicolumn{2}{|c|}{$\begin{array}{l}\text { Development of educational programs for school-linked special } \\
\text { children }\end{array}$} \\
\hline & \multicolumn{2}{|c|}{ Linkage of outreach activities with communities } \\
\hline & \multicolumn{2}{|c|}{ Planning aged people-friendly programs } \\
\hline \multirow{3}{*}{$\begin{array}{l}\text { Preparation for the } \\
\text { environment to } \\
\text { guarantee disabled } \\
\text { people's cultural } \\
\text { rights }\end{array}$} & \multicolumn{2}{|c|}{$\begin{array}{l}\text { Taking into account essentials for disabled people services in } \\
\text { institutions' operating policies }\end{array}$} \\
\hline & \multicolumn{2}{|c|}{ Operators' cultivation of disabled people's sensitivity } \\
\hline & \multicolumn{2}{|c|}{$\begin{array}{l}\text { Considering disabled people's participation within institutions' } \\
\text { operations from the social integration perspective }\end{array}$} \\
\hline
\end{tabular}

This study aims to shape an environment in which disabled people visiting or desiring to visit museums and art galleries can have diverse experiences more conveniently. This is a small first step toward the realization of a society in which disabled people cannot be discerned from normal people and where they are not discriminated or disadvantaged. This study has significance in that it encourages a more diverse group of people to visit museums and art galleries, 
including the disabled individuals. Through the guideline direction drawn in this study, "diversity" rather than "difference" is highlighted as a token of what culture and arts can offer to society.

\section{Keywords}

Disabled Person, Accessibility, Museum Accessibility, Art Galleries Accessibility, Accessibility Guideline, Museum Guideline 

장애인 접근성 강화를 위한 박물관-미술관 가이드라인 수립 방향 연구

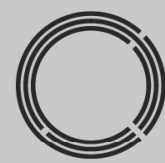

부록 

안녕하십니까? 한국문화관광연구원은 〈장애인 접근성 강화를 위한 박물관-미술관 가이드라인 수립 방향〉 연구의 일환으로 박물관·미술관 장애인 서비스 실태 조사 를 실시하고 있습니다.

장애인을 포함한 다양한 관람객의 박물관-미술관 방문 및 접근 개선방안 모색을 위하여 박물관-미술관의 장애인 서비스 관련 실태를 파악하고자 합니다. 이에 귀 기관의 입장에서 소중한 의견 부탁드립니다.

본 조사의 응답 내용은 「통계법 제33조에 의거하여 통계적으로 처리되어 현황 파악과 대안 도출을 위한 참고자료로만 사용되므로 절대적으로 비밀이 보장됩니 다. 설문에 응해주셔서 감사드립니다.

통계법 제33조(비밀의 보호)

(1) 통계의 작성과정에서 알려진 사항으로서 개인이나 법인 또는 단체 등의 비 밀에 속하는 사항은 보호되어야 한다.

(2) 통계의 작성을 위하여 수집된 개인이나 법인 또는 단체 등의 비밀에 속하 는 자료는 통계작성 외의 목적으로 사용되어서는 아니 된다.

\begin{tabular}{|c|c|c|c|c|}
\hline 응답 기관명 & & & & 박물관(）미술관( ) \\
\hline 응답자 성명(소속부서) & 성명: & /부서명: & & 연락처: \\
\hline $\begin{array}{l}\text { 2019년 기준 귀 기관의 } \\
\text { 연간 관람객수 }\end{array}$ & & & )명 & \\
\hline $\begin{array}{l}\text { 2019년 기준 귀 기관의 } \\
\text { 장애인 관람객 수 }\end{array}$ & & ( )명 / & $\%$ & $\begin{array}{l}\text { ※ 측정되지 않고 있다면, 전체 관람자 } \\
\text { 수 대비 비중(\%)만 기재 }\end{array}$ \\
\hline
\end{tabular}


귀 기관의 장애인 관람객 접근성 개선을 위한 활동에 대해서 운영정책, 조사 및 연구, 직원교육, 직원고용, 의견수렴 피드백의 5 가지 항목에 대해서 의견 부탁드립니다.

문 1) 기관에서 연간, 또는 중장기 계획으로 장애인 접근성 개선과 관련한 계획을 수립 한 적이 있으십니까?

(1) 매년 사업 계획 수립

(2) 몇 년 주기로 계획 수립

(3) 중장기계획 내 포함

(4) 주기적은 아니지만, 계획을 수립한 경험이 있음

(5) 수립 경험 없음

(6) 기타

문 2) 장애인 접근성과 관련한 내부 규정 등이 마련되어 있으십니까?

(해당되는 항목 모두 체크)

(1) 입장료 징수 등 입장에 대한 내용

(2) 장애인 이용 및 이동에 대한 시설, 설비 지침

(3) 장애인 제공 서비스에 대한 내용

(4) 장애인 보조 인력에 대한 내용

(5) 내부규정 없음

(6) 기타(

문 3) 중간관리자 급(연구관급) 이상으로 장애인 접근성 관련한 정책 또는 계획을 담당 하는 전담 직원(상주직원)이 있으십니까?

(1) 예

(2) 아니오

문4) 기관 운영 자문위원 등을 구성할 때, 장애(인) 관련한 전문가를 포함하고 계십니까?

(1) 예

(2) 아니오 
문 5) 기관 내 웹 디자인, 인테리어 디자인 담당자의 경우 장애인 접근성과 관련한 원 칙(유니버설디자인, 무장애 환경 개선 등에 대한 규정)을 숙지하고 업무를 수행 하도록 하십니까?

(1) 예

(2) 아니오

문 6) 기관의 연간 운영비에서 장애인과 관련된 프로그램 또는 사업운영에 소요되는 예산의 비율이 어떻게 되십니까?

문 6-1) 전체 운영비 대비 관련 프로그램 운영비
(1) $5 \%$ 미만
(2) $5 \sim 10 \%$ 미만
(3) $10 ~ 20 \%$ 미만
(4) $20 \%$ 이상
(5) 없음

문 6-2) 전체 운영비 대비 장애인시설 운영비
(1) $5 \%$ 미만
(2) $5 \sim 10 \%$ 미만
(3) $10 ~ 20 \%$ 미만
(4) $20 \%$ 이상
(5) 없음

문 7) 장애인 이용자에 대한 설문과 만족도 조사 등을 수행하고 계십니까?

(1) 매년 단독 진행

(2) 몇 년 주기로 단독 진행

(3) 일반인 관람객 조사 내 포함

(4) 주기적은 아니지만, 계획을 수립한 경험이 있음

(5) 수행하지 않음

(6) 기타

문 8) 장애인 접근성(시설 이용, 프로그램 이용 등)을 수시로 체크할 수 있는 체크리스 트 등이 구비되어있습니까?
(1) 예
(2) 아니오 
문 9) 기관에서 장애인 응대 또는 장애인 관련 직원 교육을 실시한 적이 있으십니까? (해당되는 항목 모두 체크)

(1) 장애인에 대한 사회적 인식 제고

(2) 장애인 이용 및 이동에 대한 시설, 설비 지침

(3) 특수 아동, 또는 특정 장애의 특징 이해

(4) 장애인 차별 금지법의 적용과 실제

(5) 일반적인 장애인 응대와 관련한 사항

(6) 실시한 적 없음

(7) 기타(

문 10) 기관 소속직원이 장애인 접근성과 관련한 내부 규정 또는 장애인 응대에 대한 원칙을 숙지할 수 있는 교육 기회 등을 제공하고 있으십니까?

(1) 기관에서 주관하는 전직원 집체 교육(연간 교육)

(2) 해당 업무 담당자(또는 담당부서) 그룹 교육

(3) 직원별 자발적 선택(신청자에 한하여)

(4) 해당 지자체 또는 국가의무 교육 형태

(5) 제공하지 않음

(6) 기타(

문 11) 귀 기관에서 장애인 프로그램 기획을 담당하는 직원 중 장애에 대한 전문 지식 을 습득한 직원이 있습니까?(학위자, 특수 교육 자격증, 교육 프로그램 이수자 포함)

(1) 예

(2) 아니오

문 12) 귀 기관에서 장애인들이 직원 또는 자원봉사자로 지원할 수 있도록 관련 정보를 제공하고 있습니까?

(1) 장애인이 쉽게 접근할 수 있는 매체 등을 활용하여 홍보함(장애인 신문, 장애인정보 플랫폼 등)

(2) 기존 활용하던 매체 등을 활용하여 홍보함

(3) 장애인을 위한 별도의 정보제공 방식 없음

(4) 기타( 
문 13) 귀 기관에 장애인이 고용되어 있습니까?

(1) 중간관리자급 이상

(2) 일반 직원: 학예, 교육 기획자

(3) 일반 직원: 일반행정

(4) 자원봉사

(5) 고용되어있지 않음

(6) 기타(

문 14) 귀 기관은 장애인 이용에 대한 의견을 이용자에게 직접적으로 수렴하는 기회를 마련하고 있습니까?

(1) 장애관련 단체로부터

(2) 이 분야에 전문성을 가진 사람으로부터

(3) 장애인으로부터(기관 방문자)

(4) 장애인으로부터(비방문자)

(5) 정부 또는 지자체 관련 공무원으로부터

(6) 의견수렴하고 있지 않음

- 박물관-미술관 환경에서 나타날 수 있는 접근의 장애요소를 다음의 4 가지로 구분하고

- 이에 대하여 귀 기관의 운영환경에 대한 의견을 듣고자 합니다.

- 감각 및 지적 접근성: 기관에서 운영되는 프로그램과 제공되는 서비스이용에 대한 접근성

- 정보 접근성: 기관이 제공하는 다양한 정보(물리적, 지적 접근성관련)에 대한 접근성

- 정서적/태도적 접근성: 기관에서 장애인을 대하는 태도로 발생되는 이용자 심리적 접근성

- 문화적 접근성: 장애 또는 장애인에 대한 관점을 사회문화적으로 접근하고자 하는 노력

문 1) 장애인을 위한 전시 안내 보조 용품 및 서비스 등을 제공하고 있습니까? (해당되 는 항목 모두 체크)

(1) 전시 안내 점자책자

(2) 약시를 위한 큰 글씨 형태 안내 책자

(3) 보청 시스템(소리 확장) 
(4) 영어를 제외한 다국어 리플렛

(5) 근육제어가 힘든 장애인을 위한 도구

(6) 교육 체험 공간 내의 장애인 이용 가능 가구(높이조절 책상, 의자 등)

(7) 수화 안내 영상 서비스

(8) 촉각을 활용한 전시 체험 서비스

(9) 장애 유형을 고려한 전시 안내 가이드 서비스

(10) 장애인 이동을 위한 이동수단 제공 서비스

(11) 기타(

문 2) 청각장애인을 위한 수화 안내 서비스를 제공하는 안내원이 고용되어 있습니까?
(1) 고용되어있지 않음
(2) 정규직 고용
(3) 계약직 고용
(4) 자원봉사
(5) 단발성 고용
(6) 기타(

)

문 3) 리플렛이나 홈페이지 등에 기관 방문 및 시설 이용방식을 장애 유형에 따라 구분 하여 설명하고 있습니까?
(1) 예
(2) 아니오

문 4) 귀 기관에서는 장애인을 대상으로 하는 프로그램을 정기적으로 운영하고 있습니 까?
(1) 예(曲문 4-1)
(2) 아니오(

문 4-1) 정기적으로 운영하고 있다면 운영주기는 어떻게 되십니까?
(1) 월 1회 이상(연 12회 이상)
(2) 분기별 1 회 이상(연 4회 정도)
(3) 연 1회 2회
(4) 기타

문 4-2) 정기적으로 운영하고 있지 않으시다면, 다음의 어떤 경우이십니까?

(1) 신청자가 있을 경우 수시로 운영

(2) 이벤트성 행사 중심

(3) 일반인 프로그램에 참여하도록 함

(4) 운영하고 있지 않음( 6 ) 
문 4-3) 장애인 프로그램 신청은 주로 어떠한 방식으로 운영하고 계십니까?

(1) 인터넷 예약

(2) 전화 예약

(3) 방문 예약

(4) 기관 간 단체 예약

(5) 프로그램 운영일에 선착순 방문

(6) 기타

문 4-4) 필요시, 장애인이 방문할 수 있도록 이동수단을 제공하고 있습니까?
(1) 예
(2) 아니오

문 4-5) 장애인 프로그램 운영시, 평균적으로 몇 명의 인원을 대상으로 진행하고 있습 니까?

(1) $1: 1$ 수업이 가능하도록 진행함

(2) 5 명 이내의 수업이 가능하도록 진행함

(3) 6 10명 이내로 수업이 가능하도록 진행함

(4) 10 명 이상의 집체교육으로 진행함

(5) 프로그램에 따라 교육 인원수를 조정함

(6) 기타

문 4-6) 장애인 프로그램이 주로 진행되는 영역은 어느 영역입니까? (1순위: $\quad / 2$ 순위: )
(1) 전시영역
(2) 교육영역
(3) 행사영역
(4) 홍보 및 교류 영역
(5) 연구영역
(6) 기 타 (

문 4-7) 장애인 프로그램의 대상 연령층은 어떻게 되십니까?(해당되는 항목 모두 체크)
(1) 어린이
(2) 청소년
(3) 성인
(4) 노인
(5) 유아를 동반한 가족
(6) 전 연령(특정 대상연령층 없음) 
문 4-8) 실제로 가장 활발히 진행되는 장애인 프로그램의 대상층은 어떻습니까?
(1) 어린이
(2) 청소년
(3) 성인
(4) 노인
(5) 유아를 동반한 가족

문 4-9) 운영되고 있는 장애인 프로그램 대상층의 장애특성은 어떻습니까?(해당되는 항목 모두 체크)

(1) 청각장애

(2) 시각장애

(3) 지체장애

(4) 발달장애(어린이의 경우)

(5) 정신장애(발달장애를 제외한 정신적 장애)

(6) 노인성 장애(치매 등)

문 5) 장애인을 대상으로 하는 기관에 방문하여 프로그램을 진행하는 아웃리치 프로그 램이 있습니까? (

(1) 교육기관(특수, 일반학교 장애학급) 방문프로그램

(2) 복지관 방문 프로그램

(3) 장애인 시설 방문 프로그램

(4) 아웃리치 프로그램이 없음

(5) 기타(

문 6) 귀 기관에서 장애인관련 프로그램을 운영하고 있지 않다면, 그 이유는 무엇입니 까?(1순위: /2순위: )

(1) 프로그램 수요가 거의 없기 때문에

(2) 예산의 한계로 프로그램 운영이 힘들어서

(3) 운영할 수 있는 인력이 부족해서

(4) 관련한 프로그램 운영 필요성을 느끼지 못해서

(5) 운영에 대한 노하우가 없어서

(6) 기타( 
문 7) 귀 기관의 홈페이지는 장애인의 이용에 대한 웹접근성을 고려하여 구성되어 있습 니까?

- 웹 접근성(web accessibility)은 장애인이나 고령자분들이 웹 사이트에서 제공하는 정보를 비장애인과 동등하게 접근하고 이용 할 수 있도록 보장하는 것으로 이에 대한 준수는 법적의무사항임

- 웹접근성 준수 고려사항으로는 시각, 이동성, 청각, 인지 영역이 있으며, 관 련 기술로는 스크린리더 소프트웨어, 화면확대 도구, 음성인식, 키보드 오버 레이가 있음
(1) 예(망문 7-1)
(2) 아니오(뭉 8)

문 7-1) 웹접근성을 고려하였다면, 설계 시 어떠한 방식으로 진행하셨습니까?

(1) 홈페이지 초기 설계부터 계획 하에 진행함

(2) 홈페이지가 완성된 이후 리뉴얼 방식으로 진행함

(3) 관련 내용을 지속적으로 업데이트하는 방식으로 진행함

(4) 기타

문 8) 홈페이지 내 장애인 이용을 위한 별도의 서비스 페이지가 구성되어 있습니까? (해당되는 항목 모두 체크)

(1) 기관 방문 및 이용 안내에 대한 설명 페이지

(2) 교육 프로그램에 대한 간략한 소개 및 참여방식 등 정보제공 페이지

(3) 프로그램 내용에 대한 자세한 설명과 관련한 자료 다운로드 제공 페이지

(4) 별도 페이지 없음

(5) 기타 (

문 9) 장애인 관련 프로그램 운영 시, 어떠한 방식으로 홍보를 진행하십니까?(해당되는 항목 모두 체크)

$\begin{array}{ll}\text { (1) 홈페이지 알림 } & \text { (2) 관련기관 공문 발송 }\end{array}$

$\begin{array}{ll}\text { (3) 관련기관 전화홍보 } & \text { (4) 관련기관 방문홍보 }\end{array}$

(5) 일반 프로그램과 동일하게 운영

(6) 홍보 없음(프로그램 운영하지 않는 경우 포함)

(7) 기타( 
문 10) 장애인 정보 접근성을 높이기 위하여, 가장 최신으로 구입 또는 설치한 매체, 시스템, 장비 등이 있으십니까?

(1) 예(장비명:

(2) 아니오

문 11) 귀 기관은 장애인 방문과 관련하여 친화적인 태도를 취하고 있다고 보십니까?
(1) 매우 그렇다
(2) 그런 편이다
(3) 보통이다
(4) 그렇지 않은 편이다
(5) 전혀 그렇지 않다

문 12) 귀 기관은 장애인 방문이 많아질 수 있는 다양한 방식의 접객 서비스 개발을 적극적으로 하고 계십니까?
(1) 매우 그렇다
(2) 그런 편이다
(3) 보통이다
(4) 그렇지 않은 편이다
(5) 전혀 그렇지 않다

문 13) 귀 기관에서 최근 5년 내에 장애(장애를 바라보는 관점), 장애인, 장애활동, 장 애 예술(장애예술가 참여)을 테마로 한 전시를 진행한 적이 있습니까?

(1) 예(전시명:

해당연도:

(2) 아니오(문 14)

문 13-1) 해당 전시를 어떻기 기획하게 되셨습니까?(해당되는 항목 모두 체크)

(1) 자체 아이디어 회의를 통한 기획

(2) 유관 단체와의 협력 관계를 통한 기획

(3) 관련 정부/지자체 행사일정과 연계

(4) 장기적인 시리즈 기획에 따른 진행

(5) 기타(

문 14) 귀 기관에서는 장애 또는 장애에 대한 관점 등을 공유하기 위한 정기적 혹은 비정기적인 학술/이벤트 등을 개최하고 있으십니까?
(1) 예
(2) 아니오 
문 15) 귀 기관에서 장애와 관련한 프로그램을 운영할 때, 어떠한 방향으로 프로그램이 기획 운영되고 있습니까?(해당되는 항목 모두 체크)

(1) 소외계층 프로그램

(2) 문화적 다양성

(3) 포용적 민주 시민의식 함양

(4) 문화적 향유 기회 확대

(5) 표현의 자유, 다양한 표현형식

(6) 프로그램 운영하지 않음

(7) 기타 ( 

집필내역

연구책임

김현경 한국문화관광연구원 연구원: 제1장 제6장 연구총괄

장애인 접근성 강화를 위한

박물관·미술관 가이드라인 수립 방향 연구

발행인 김대관

발행처 한국문화관광연구원

서울시 강서구 금낭화로 154

전화 02-2669-9800 팩스 02-2669-9880

http://www.kcti.re.kr

인쇄일 2020년 10월 13일

발행일 2020년 10월 13일

인쇄인 (사)한국장애인이워크협회 일자리사업장

I S B N 978-89-6035-822-593300

DOI https://doi.org/10.16937/kcti.rep.2020.e4 


\section{A Study on Establishing the Guideline of Museums and Art Galleries for Accessibility of Disabled Persons}

